Milk, Marias, and St. Mary

Monitoring: Developing

a Long-term Rotating

Basin Wetland Assessment

and Monitoring Strategy

for Montana

Prepared for:

U. S. Environmental Protection Agency

Prepared by:

Catherine McIntyre, Karen Newlon, Linda Vance, and Meghan Burns

Montana Natural Heritage Program

a cooperative program of the

Montana State Library and the University of Montana

March 2011

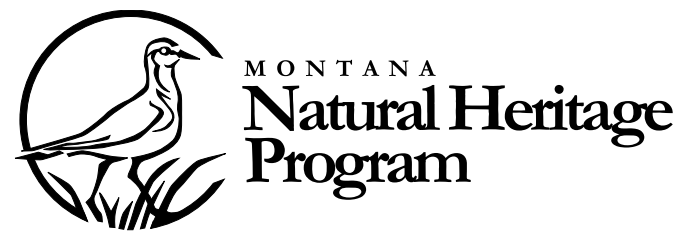





\section{Milk, Marias, and St. Mary Monitoring: Developing a Long-term Rotating Basin Wetland Assessment and Monitoring Strategy for Montana}

Prepared for:

U. S. Environmental Protection Agency

Agreement Number:

CD - 97854401

Prepared by:

Catherine McIntyre, Karen Newlon, Linda Vance, and Meghan Burns

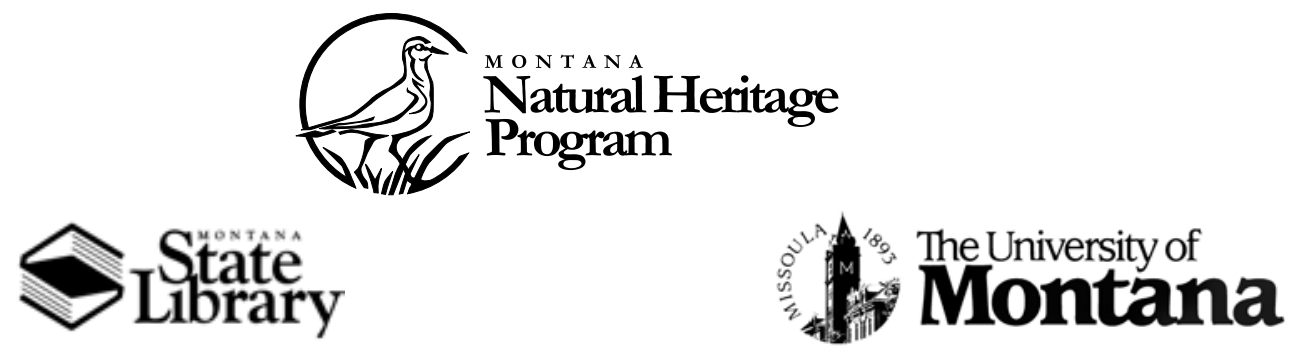

(C) 2011 Montana Natural Heritage Program

P.O. Box $201800 \bullet 1515$ East Sixth Avenue • Helena, MT 59620-1800 • 406-444-5354 
This document should be cited as follows:

McIntyre, Catherine, Karen Newlon, Linda Vance, and Meghan Burns. 2011. Milk, Marias, and St. Mary Monitoring: Developing a Long-term Rotating Basin Wetland Assessment and Monitoring Strategy for Montana. Report to the United States Environmental Protection Agency. Montana Natural Heritage Program, Helena, Montana. 35 pp. plus appendices. 


\section{Executive Summary}

Wetlands are important landscape features that provide critical ecosystem services. Properly functioning wetlands retain sediment, attenuate floods, recharge groundwater, and cycle nutrients. They are particularly important in the arid West, where only a small fraction of the landscape supports wetlands. Although the passage of the Clean Water Act (CWA) in 1972 initiated federal regulations to protect wetlands, the ambient condition of wetlands continues to be degraded nationwide (National Research Council 2001). Under Section 305(b) of the CWA, all waters of the United States (including wetlands) must be monitored and assessed every two years.

To understand the condition of wetlands and riparian areas in Montana, the Montana Natural Heritage Program (MTNHP) conducts ecological integrity assessments (EIA) of wetlands and riparian areas in Montana. This report describes the MTNHP pilot project conducted as an initial step in developing a statewide rotating-basin assessment and monitoring strategy. The primary objective of the pilot project was to conduct Level 1-2-3 assessments, describe wetland condition, and identify potential anthropogenic stressors in the Milk, Marias, and St. Mary's watersheds in Montana. The target population for assessments was palustrine emergent, scrub-shrub, and forested wetlands.

We used National Wetland Inventory (NWI) polygons mapped from 1980's aerial photography to generate a pool of potential sample sites (i.e., the sample frame) for random site selection. The survey design followed a Generalized Random Tessellation Stratified (GRTS) procedure for discrete objects with reverse hierarchical randomization. This approach accounts for the spatial patterning inherent in ecological systems.

We conducted a Level 1 landscape analysis to characterize potential landscape level disturbances at three spatial scales $(100,300$, and 1,000 meters) around the wetland perimeter. The Level 1 landscape analysis also included landscape profiles using 161,003 NWI palustrine wetland polygons and ancillary data sources to summarize these and other attributes at the fourth, fifth, and sixth code hydrologic unit levels.

We performed Level 2 rapid wetland assessments at 123 sites selected for field data collection. Field ecologists used the Montana EIA form to assess wetland condition for all wetland types within the project area. The EIA approach uses a set of ecological attributes that reflect both the structure and function of the wetland to assess ambient condition. Each ecological attribute contains one or more indicators to represent the status or trend of the attribute. These indicators are measured by metrics that include narrative ratings scaled along a gradient of wetland condition status. Each metric consists of three to five narrative statements that are assigned along an ordinal scale value. Higher numbers correspond with increasing levels of disturbance. Each metric rating is summarized into an overall attribute score for five attributes: 1) Landscape Context; 2) Relative Patch Size; 3) Biotic; 4) Physicochemical; and 5) Hydrology. The ratings for these five attributes are then combined to produce an overall EIA condition score.

The MTNHP EIA method uses vegetation as an intensive biological measure to assess wetland condition. Intensive Level 3 vegetation data were collected at 44 of the Level 2 sites using a $20 \mathrm{~m} \mathrm{x}$ $50 \mathrm{~m}$ relevé plot. Level 3 vegetation data were used to conduct a Floristic Quality Assessment (FQA).

The Level 1 landscape analysis showed little variability at all three spatial scales. This is due, in part, to the homogeneity of the landscape within the project area. The dominant land uses in this part of Montana are dry land farming and livestock grazing, and much of the area is intersected by local dirt roads. With so little variability in the landscape, the landscape level analysis did not provide a reliable assessment of wetland condition. Wetland profile results indicated that $81 \%$ of the wetlands within the project area are palustrine emergent wetlands with either temporary or seasonal water regimes. Approximately 101, 400 acres of depressional wetlands occur within the project area. Three watersheds had a greater number of altered wetlands than unaltered wetlands. 
Results for the Level 2 rapid assessments indicate that among depressional wetlands, Great Plains Prairie Potholes and Great Plains Saline Depressions are in better condition than either Great Plains Open or Closed Depressions. Results for open and closed depression wetlands indicate that these systems are highly susceptible to human disturbances. Northwestern Great Plains Riparian systems also had more sites ranked as severely altered, suggesting that these systems need more focused protection.

Our Level 3 results indicate that most of the wetlands assessed are dominated by species that can tolerate moderate disturbance as demonstrated by the cover-weighted mean c-values ranging from four to six. In addition, lower adjusted FQI values indicate that most of the assessed sites are dominated by plants that are frequently found in disturbed sites.

The dominant human disturbances observed and affecting wetland condition in the project area include roads, conversion of temporary and seasonal wetlands to dryland farming and stock ponds, and soil and vegetation disturbance associated with heavy livestock grazing. Effects of human induced disturbance may covary with natural disturbances including drought. Drought may affect wetland condition more than either local or landscape level human disturbances.

There are several confounding issues with assessing wetlands in this region. Depressional wetlands are dynamic systems where wet-drought cycles influence the ecological communities present. Therefore, our assessments are just a snapshot of the ecological condition of the wetland at that stage within its wet-drought cycle. Because assessment results may change depending on the wet-drought cycle it is important to assess reference wetlands over a long period of time to establish a gradient of known conditions for wetlands with different water regimes.

Both the Level 1 and Level 2 analysis need further calibration and refinement based on intensive Level 3 assessments. Additional Level 3 assessments should be developed to help in the further validation of our methods. Based on this pilot project, the MTNHP will continue to develop indicators and metrics for a long-term integrated, statewide, multijurisdictional wetland condition monitoring and assessment strategy based on EPA's recommended elements. 


\section{ACKNOWLedGements}

This project was funded by an Environmental Protection Agency Region 8 Wetland Program Development Grant. We would like to thank Toney Ott and Jill Minter of EPA Region 8 for their support and commitment to wetland assessment and monitoring in our region.

This project would not have been successful without the help of many dedicated individuals including Jessica Clarke, Larissa Pfleeger, Tara Luna, and Eva Mason who spent long buggy days in the field collecting quality data, as well as Randy Apfelback, Lynda Saul, and Stephen Carpenedo of MT DEQ who provided feedback and advice on the field protocol. Catherine Maynard of the NRCS provided helpful recommendations on content and editorial feedback. Joanna Lemly of the Colorado Natural Heritage Program acted as a sounding board for many ideas and provided helpful suggestions for data analysis. Allan Cox of MTNHP developed the webpage for this project on the MTNHP website.

Also, thanks to Tony Olsen with the Environmental Protection Agency who provided guidance on using GRTS and to Coburn Currier of MTNHP for formatting and editing the final version of this report.

Finally, thanks are due to the Monitoring and Assessment Workgroup of the Montana Wetland Council for their support and guidance through the development of the MTNHP Level 1-2-3 protocol. In particular, thanks to Mike Philbin from the Bureau of Land Management for all his support and dedication to wetlands and riparian areas in Montana.

Any errors or omissions in the report are entirely the responsibility of the authors. 


\section{Table of Contents}

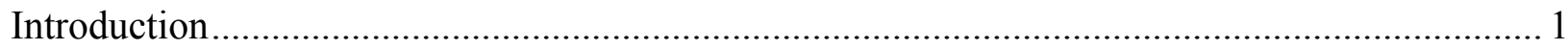

Study Area

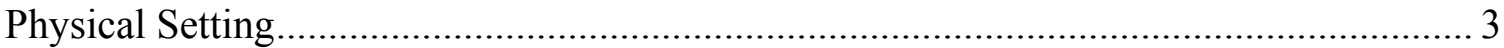

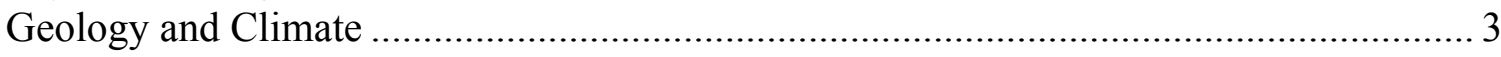

Vegetation and Ecological Processes ............................................................................

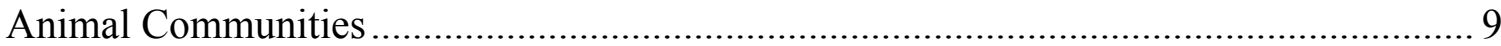

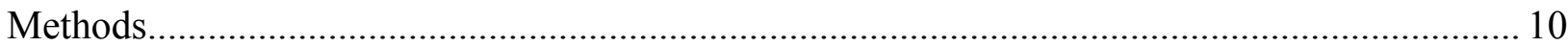

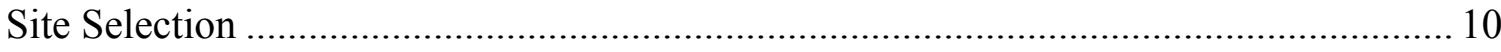

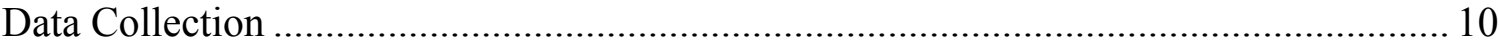

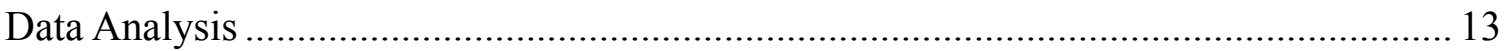

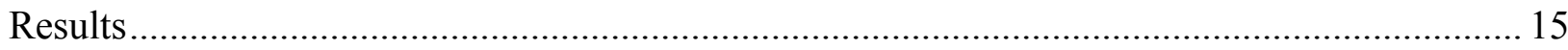

Wetland Landscape Profile Results ............................................................................... 15

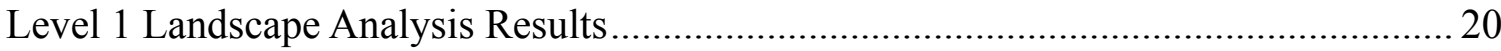

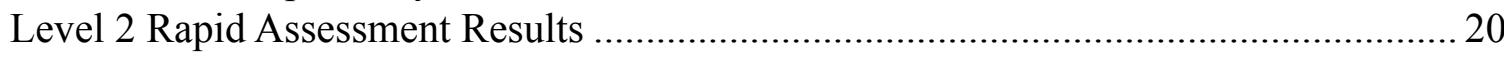

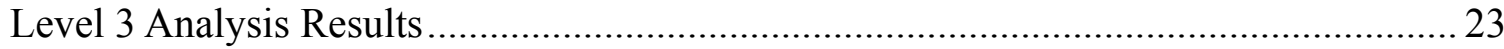

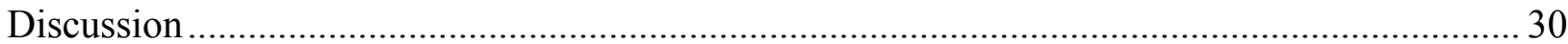

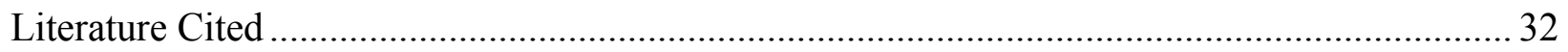

Appendix A: Ecological System Descriptions

Appendix B: Ecological System Field Key

Appendix C: Level 1 Digital Data Set Sources and Scoring

Appendix D: Montana Natural Heritage Program Level 2 Ecological Integrity Assessment Form Appendix E: Calculation of Level 2 Attribute and Overall AA Scores

Appendix F: Montana Natural Heritage Program Level 3 Intensive Vegetation Assessment Form

Appendix G: Vegetation Cover Classes and Relevé Plot Layout

Appendix H: Calculation and Description of Floristic Quality Assessment Indices

Appendix I: Wetland Landscape Profiling

Appendix J: Level 1 Attribute Frequency Histograms for Three Landscape Scales

Appendix K: Level 2 Attribute Frequency Histograms

Appendix L: Level 2 Scores for Each Ecological System

Appendix M: Level 2 Attribute and Overall Condition Score Frequency Histograms by Wetland Ecological Systems for Systems with $n=\geq 8$ sites.

\section{List of Figures}

Figure 1. Watersheds included in the Milk, Marias, and Saint Mary Rivers project area ........... 3

Figure 2. Level III Ecoregions included in the project area...................................................... 4

Figure 3. Relative annual precipitation (REAP) in inches for the project area ……….............. 5

Figure 4. Acres of mapped wetlands within the project area................................................... 15

Figure 5. Density of wetlands by fourth code hydrologic units within the project area........... 16

Figure 6. Percent of wetlands in the project area that are located on private land ................... 19

Figure 7. Percent of wetlands in the project area that are considered altered............................2 20

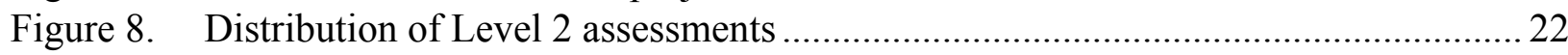

Figure 9. Overall condition scores for Level 2 wetland sites.................................................... 24 


\section{List of Figures (Con't)}

Figure 10. Overall condition scores for the dominant ecological systems within the project area

Figure 11. Mean C-Values weighted by the relative average cover of plant species in

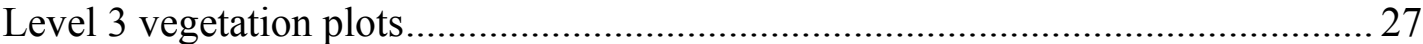

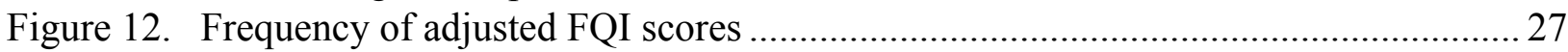

Figure 13. Effects of heavy livestock grazing on wetland soil and vegetation............................2 28

Figure 14. Frequency of species by their regional wetland indicator status ................................2 28

\section{LIST OF TABLES}

Table 1. The Montana Natural Heritage Program Rapid Assessment Method attributes and component metrics.......................................................................................... 11

Table 2. Predicted responses of vegetation metrics to increasing levels of human disturbance

Table 3. Summary table of number, acres and percentage of total wetland acres by Cowardin classification water regime and class and associated hydrogeomorphic type and code.

Table 4. Wetland landscape profiling of palustrine wetlands within each fourth code hydrological unit (HUC)

Table 5. Mean Level 1 scores for landscape metrics, attributes and overall site score with standard deviations (S.D.).

Table 6. Number of Level 2 sites by Level IV Ecoregion, 4th code hydrological unit, and hydrogeomorphic type (HGM).

Table 7. Mean overall EIA scores with their standard deviations and minimum and maximum scores for each ecological system

Table 8. Correlations between Level 2 attribute scores and Cowardin water regimes using Spearman's correlations

Table 9. Correlations between Level 2 attribute scores and the number of different stressor types using Spearman's correlations

Table 10. Mean values for FQA indices by Cowardin water regime with their standard deviations (S.D.)

Table 11. Spearman correlations between Level 3 vegetation data and relative effective annual precipitation (REAP) 



\section{INTRODUCTION}

Wetlands are important landscape features that provide critical ecosystem services. Properly functioning wetlands retain sediment, attenuate floods, recharge groundwater, and cycle nutrients. These critical biological functions also have the potential for significant socioeconomic impacts. These functions are particularly important in the arid West, where only a small fraction of the landscape supports wetlands. Historically, nearly $25 \%$ of Montana's wetlands have been lost since 1780 (Dahl 1990, Jones 2003). Although the passage of the Clean Water Act (CWA) in 1972 initiated federal regulations to protect wetlands, the ambient condition of wetlands continues to be degraded nationwide (National Research Council 2001). Under Section 305(b) of the CWA, all waters of the Unites States (including wetlands) must be monitored and assessed every two years. Reporting on the ambient condition of wetlands is necessary to determine if management and restoration practices are succeeding (Kentula 2007).

The CWA requirement for States to report on the condition of State waters and wetlands underscores the need for a comprehensive wetland monitoring and assessment program in Montana. To adequately characterize wetland condition and prioritize conservation, restoration and management, wetland assessments should be conducted within a watershed context (National Research Council 2001, White and Fennessy 2005, Brooks et al. 2006) and at multiple spatial scales (Brooks et al. 2004). The Ecological Integrity Assessment (EIA) Framework provides a scientifically sound methodology for these types of biological and ecological resource assessments (Kentula 2007). "Ecological integrity" is the ability of an ecosystem to support and maintain a full suite of organisms with species composition, diversity, and function comparable to systems in an undisturbed state (Karr and Dudley, 1981). It varies along a continuum of anthropogenic influences or disturbances. At one end of this continuum are pristine or minimally impacted systems, supporting the full complement of ecological processes. With increasing human disturbance, the condition of these systems may decline (Karr and
Chu 1999). An EIA assessment framework uses multi-metric indices to evaluate the ecological integrity of wetlands at multiple spatial scales. By integrating landscape level land-use data and sitelevel condition assessments, the EIA framework provides comprehensive, watershed level wetland integrity evaluations, and meets regional and site specific information needs.

The Montana Natural Heritage Program (MTNHP) conducts ecological integrity assessments for wetlands in Montana using the EIA framework, augmented with methods developed by ecologists from other state Natural Heritage programs and the NatureServe network (Faber-Langendoen et al. 2006, 2008; Rocchio 2006a, 2006b). The MTNHP multi-scale EIA follows the three-tier approach recommended by the U.S. Environmental Protection Agency (EPA). The first tier is a Level 1 GISbased landscape assessment using available digital data to provide information on watershed condition. Its primary metrics are based on anthropogenic stressors such as roads, resource extraction, and land conversion from native vegetation to agriculture or residential development. The Level 1 assessment also includes wetland profiles summarizing general information on wetland abundance, type, extent, and function within a given watershed (Johnson 2005). The second tier (Level 2) is a rapid field-based assessment using a suite of metrics to record the general condition of individual wetlands. These metrics evaluate various indicators of landscape context, biotic, hydrologic, and physicochemical condition. Finally, a detailed quantitative Level 3 field assessment is conducted and used to calculate site-specific indices of biological integrity (refer to Appendix B for field form). Using the three-tiered approach, information from each level is used to validate the results of the other levels (Kentula 2007). The multi-tiered approach allows the ambient condition of wetlands to be monitored over time and spatially referenced. Management decisions and actions can then be prioritized so that sites in good condition can be protected and sites that have been impacted can be selected for restoration. 
This report describes the MTNHP pilot project conducted as an initial step in developing a statewide rotating- basin assessment and monitoring strategy. The primary objective of the pilot project was to conduct Level 1-2-3 assessments, describe wetland condition, and identify potential anthropogenic stressors in the Milk, Marias, and St. Mary watersheds in Montana. These watersheds were selected because of their biological and socioeconomic importance and the availability of complete digital wetland mapping from the National Wetland Inventory (NWI). 


\section{Study Area}

\section{Physical Setting}

The project area is located in north central Montana and includes Glacier, Liberty, Toole, Pondera, Teton, Hill, Blaine, Phillips, Chouteau, and Valley Counties. The study area extends from Glacier National Park on the Rocky Mountain Front east across the foothills and the glaciated plains. It lies within the southwestern edge of the Prairie Pothole region, an area with national and global ecological significance (Mitsch and Gosselink 2000). Unlike many significant natural areas in the U.S., the Prairie Pothole region of northern Montana is not the subject of focused state or federal protection efforts. Lands are primarily privately owned with federal and state ownership scattered throughout the watersheds. Land use is divided between livestock grazing on native prairie, dryland farming, and hay production. Three river basins were used to delineate the study area: those portions of the St.
Mary and Milk River Basins that fall within Montana, and all of the Marias River (Figure 1).

\section{Geology and Climate}

The project area includes 15,794,321 acres and includes portions of four Level III ecoregions (Omernik 1987): the Canadian Rockies, the Northwestern Glaciated Plains, the Middle Rockies, and the Northwestern Great Plains. However, most of the project is within the Northwestern Glaciated Plains ecoregion (Figure 2). The western edge is rugged and forested, with outcrops of Precambrian Belt rock. Geologically, it is characterized by drift deposits, colluvium, moraines, glacially carved U-shaped valleys, kettle ponds, and poorly developed drainage networks. Elevations in this area can exceed 3,000 meters; highest elevations have lingering snow, and are mostly talus and rock. By contrast, the central and eastern portions are

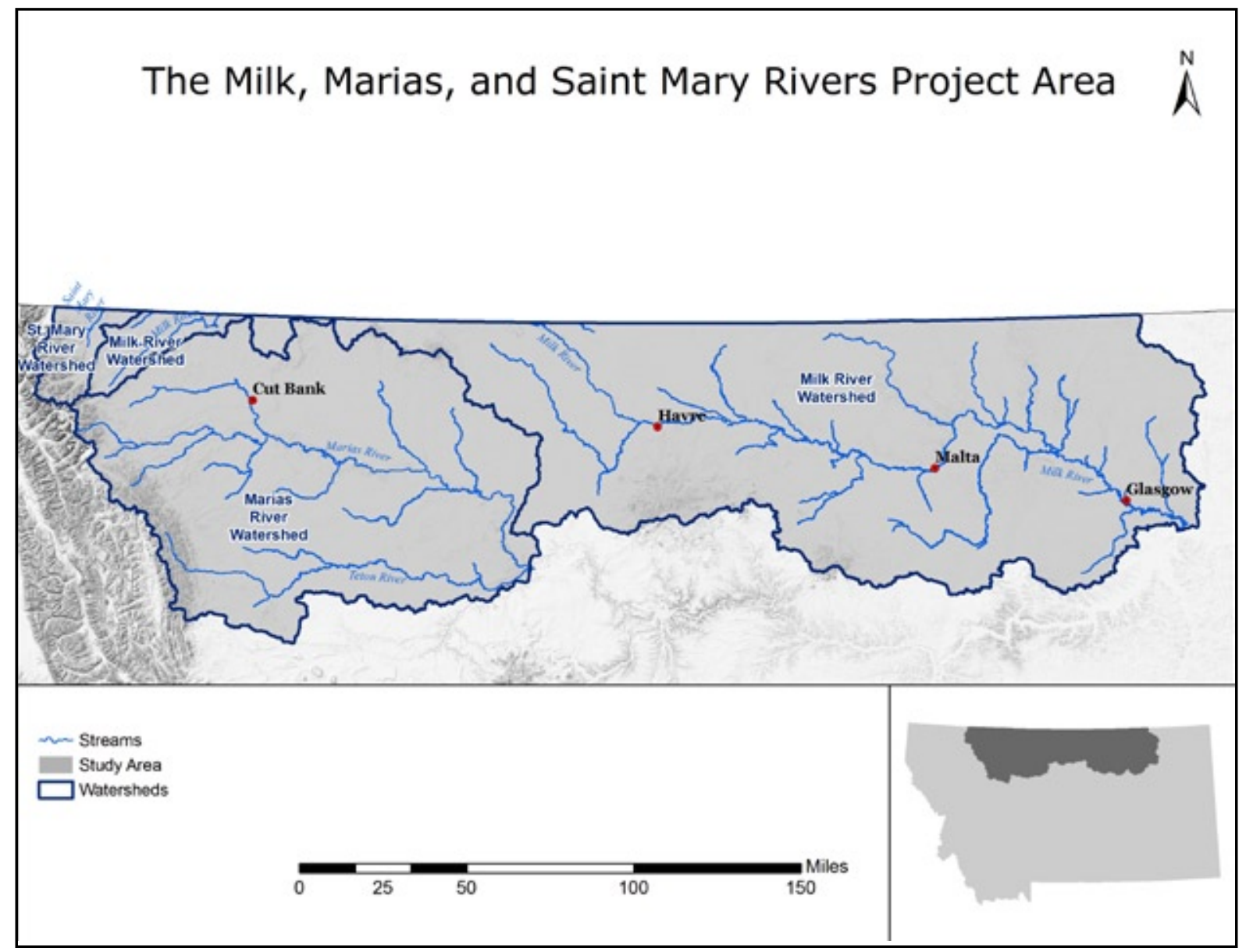

Figure 1. Watersheds included in the Milk, Marias, and Saint Mary Rivers project area. 
dominated by plains, terraces, and floodplains that formed in glacial till, by gravel deposits, and by alluvium over clay shale, sandstone, and siltstone (Nesser et al. 1997). Unlike the western front, the prairie portion has minor vertical relief. Elevations along the Milk River range from 750 meters near Fresno Dam to 600 meters at Glasgow, while elevations along the Marias River range from 900 meters at Tiber Dam to 750 meters at its confluence with the Missouri River. The Northwestern Glaciated Plains ecoregion is the most westerly edge of glaciation and is dominated by both moraines and depressional wetlands carved out by the Keewatin ice sheet (Jones 2003). Glacial till, outwash, and drift up to 30 meters thick overlay the rolling terrain (Nesser et al. 1997). The most extensive geologic substrate in the study area, extending from Canada to the Missouri River, is marine-origin clay shale and shale of the Bearpaw and Claggett formations. Sandstone and sandy shale is locally common and is most abundant in the breaks along the Marias and Milk Rivers. Quaternary age alluvium fills most of the valley bottom of the Milk River.

Climate varies widely from the western to eastern parts of the study area. Relative effective annual precipitation (REAP), which is an indicator of the amount of moisture available at a given location accounting for precipitation, slope, aspect, and soil properties, ranges from over 1,524 $\mathrm{mm}$ (60 in) in the western portion of the project area to $406 \mathrm{~mm}$ (16 in) in the eastern portion (Figure 3 ). The climate is continental and temperate with frigid winters and warm to hot summers (McNab and Avers 1994). Mean January low temperatures ranges from $-10.5^{\circ} \mathrm{C}\left(13.1^{\circ} \mathrm{F}\right)$ at East Glacier in the west to $-14.1{ }^{\circ} \mathrm{C}\left(6.7^{\circ} \mathrm{F}\right)$ at Malta in the east. Mean July high temperatures range from $23.6^{\circ} \mathrm{C}\left(74.4^{\circ} \mathrm{F}\right)$ at East Glacier to $30.9^{\circ} \mathrm{C}\left(87.7^{\circ} \mathrm{F}\right)$ at Malta (Western Regional Climate Center 2010). Across the area, precipitation peaks in late spring or early summer with steady, soaking frontal system rains. Summer

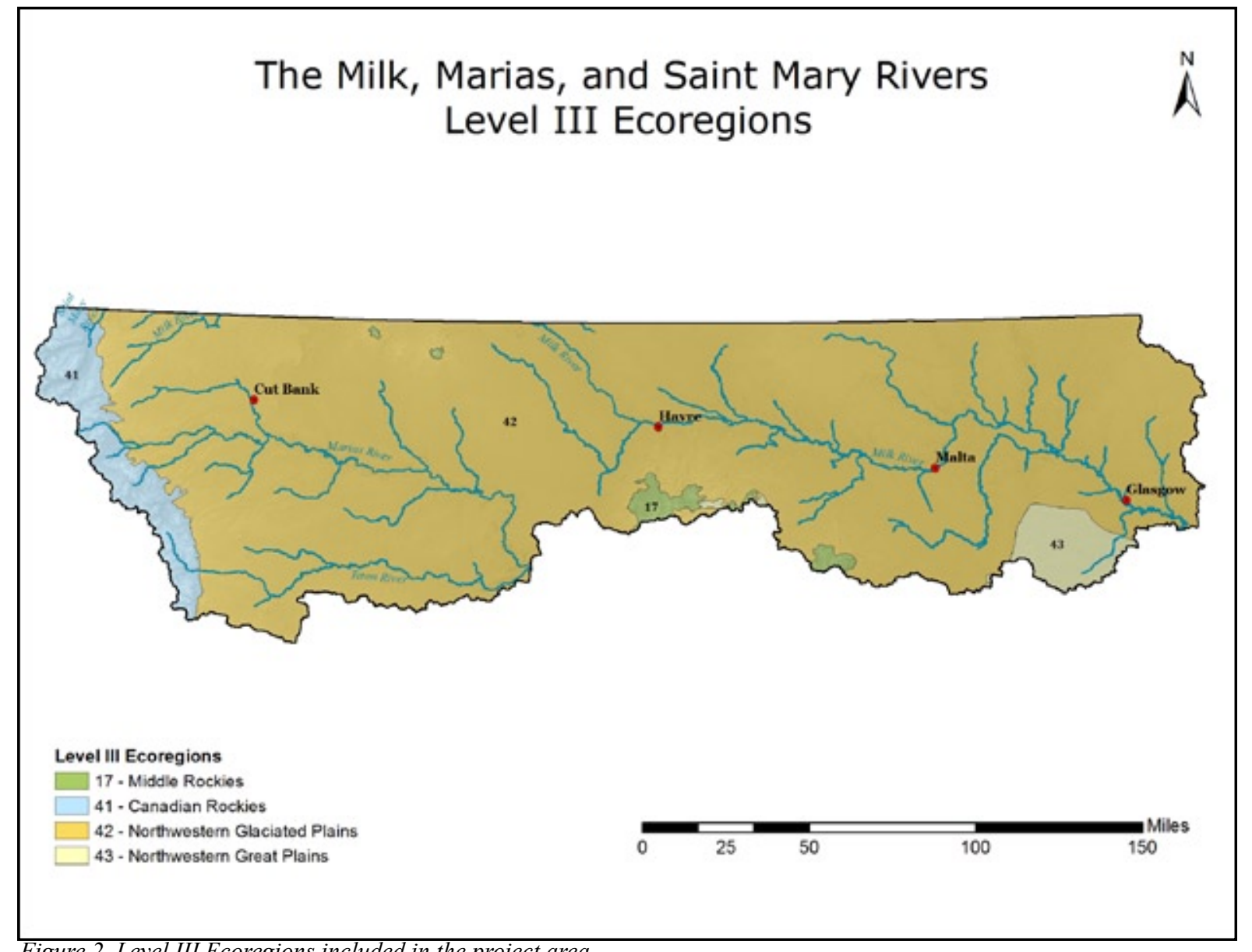

Figure 2. Level III Ecoregions included in the project area. 
rainfall comes mainly from convection thunderstorms that typically deliver bursts of intense rain in scattered locations. These storms are often accompanied by large diameter hail and flash floods (Jones 2003). Where rainfall exceeds evapotranspiration, conditions are suitable for agriculture, particularly cereal grains. The growing season across the farmed areas is typically $110-130$ days, with approximately $70-80 \%$ of annual precipitation falling within that period (McNab and Aver 1994).

The Milk, Marias and St. Mary Rivers originate on the Rocky Mountain Front. The Milk begins in the foothills north of Browning, Montana at the confluence of the South and Middle Fork of the Milk River. The Milk River joins the North Fork of the Milk River and flows into Fresno Reservoir, east of Havre, Montana. After flowing through a series of diversion dams below the reservoir, the Milk River joins the Missouri River 12 miles downstream of Fort Peck Dam. The Marias River begins in the foothills of the Rocky Mountains on the Blackfeet Indian Reservation at the confluence of Cut Bank, Dupuyer, and Birch Creeks and the Two Medicine River. It flows southeastward to Lake Elwell, formed by Tiber Dam. From Lake Elwell, a recreation and irrigation facility, the river flows east and south for 50 miles before entering the Missouri River at Loma.

The St. Mary River begins in Glacier National Park and flows through the Blackfeet Indian Reservation. Over 150,000 acre feet of water is diverted from the St. Mary into the North Fork of the Milk through a canal and inverted siphon. The remaining water flows into Canada and ultimately into Hudson Bay.

Tributary streams in the westernmost part of the study area are perennial or intermittent, fed by groundwater, snowmelt, and spring/summer rains. In the eastern part of the study area, except around

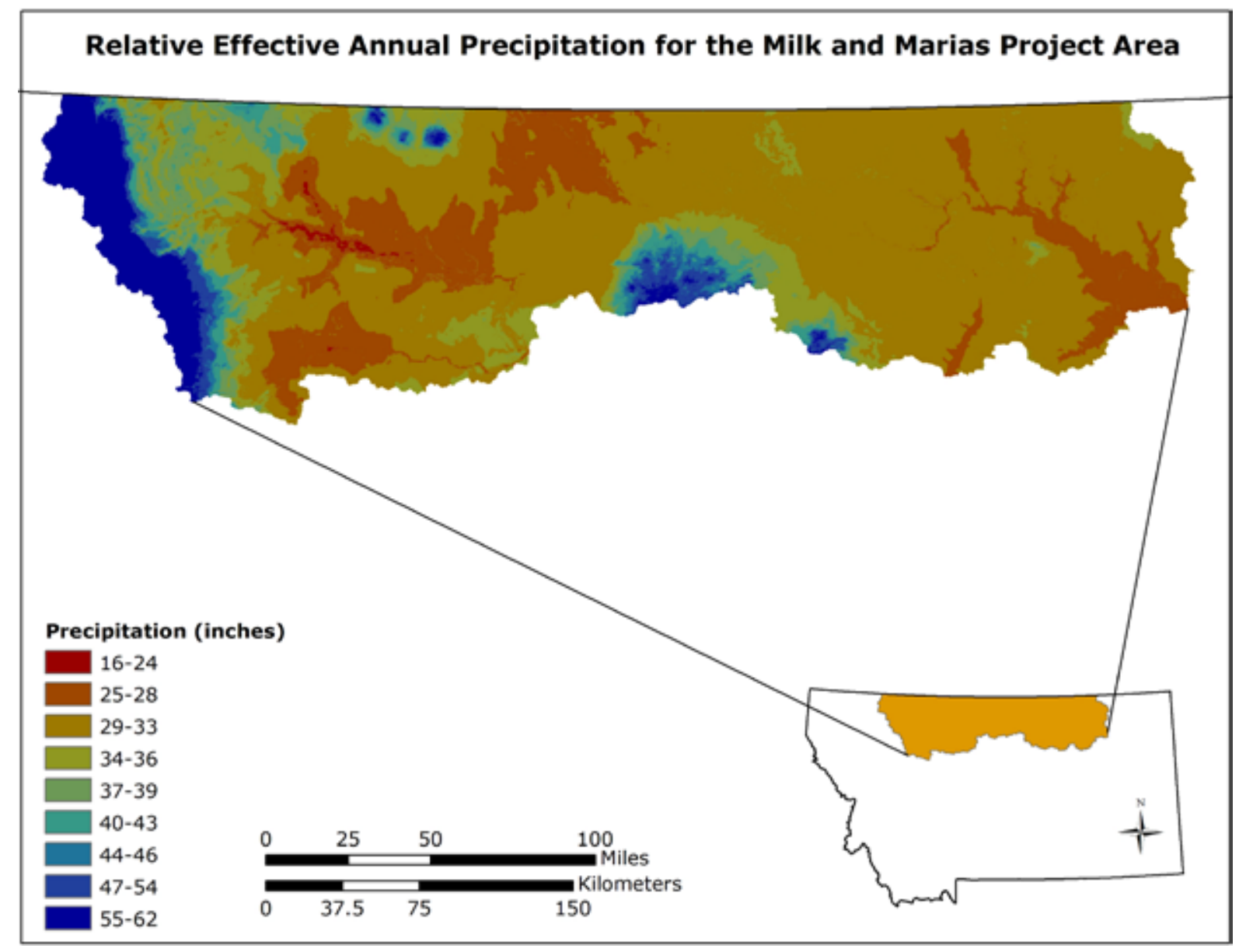

Figure 3. Map showing the relative annual precipitation (REAP) in inches for the project area. 
the Bears Paw Mountains, most tributaries are intermittent or ephemeral (Vance 2009). In the east, snow depths in winter seldom exceed 3-6 inches, but wind redistributes snow to lee positions and swales, where subsequent compaction results in considerably higher moisture content than on flats. These swales may also concentrate rainfall during late spring and during summer storm events, creating ephemeral channels.

Wetland hydrology in the study area is also complex. In the western portion, and especially on the Blackfeet Reservation, there are numerous carrs and fens along the mountain to valley transition zone. The central and eastern portions are characterized by prairie potholes, open and closed depressional wetlands, saline depressions, and emergent marshes (full ecological system descriptions in Appendix A and Ecological System Field Key in Appendix B). Depressional wetlands occur in the Milk River in the area around the Bowdoin National Wildlife Refuge, often occupying old oxbows of the pre-glacial Missouri River. Prairie potholes occur across the study area, but are most densely concentrated in the area north of US Route 2, where poorly defined or nonexistent surface drainage channels are a characteristic of the rolling landscape. Fine-textured, low-permeability soils limit infiltration (Winter 1989), and small drainage basins concentrate even the small amount of surface runoff. Rainfall accumulates rapidly in potholes during spring months, especially when infiltration is hindered until after the ground thaws. Snowmelt is the primary source of water for these systems as well as springtime rains so that water levels are typically higher in the spring and early summer as opposed to later in the summer from summer rain and runoff events (Winter 1989). Depressional and prairie pothole wetlands can be temporarily, seasonally, or semipermanently flooded. Temporary wetlands typically are small shallow basins that only hold water for one to two months (Johnson et al. 2010). Seasonal wetlands tend to be larger basins that will hold water for up to two to three months (Stewart and Kantrud 1971, Johnson et al. 2010). Depressional wetlands that are clustered on the landscape are defined as wetland complexes and are often connected to one another hydrologi- cally through both surface water and groundwater (Winter and Rosenberry 1995, Johnson et al. 2010).

Evapotranspiration appears to be the primary conduit for water loss (Shjeflo 1968). In Montana's semiarid climate, evapotranspiration will generally be much greater than precipitation during summer months. Moreover, the same clay and silt soils that limit infiltration when wet are prone to developing secondary cracks during dry months, resulting in rapid infiltration when summer rain events occur. Consequently, prairie potholes will be relatively dry throughout most years, and only hold measurable amounts of water in years when precipitation significantly exceeds average.

Although precipitation and evapotranspiration are the principal drivers of water exchange in prairie potholes, both subsurface and surface interactions can occur between individual wetlands. Subsurface flows are well-documented (reviewed by Winter 1989), and allow water retention over significant periods of time, far exceeding what would be expected if only surface inputs and evaporation are considered (Winter and Rosenberry 1995). Depending on the underlying geology and hydraulic head, individual wetlands can be recharge wetlands, discharge wetlands, or flow-through wetlands; topographic position alone is insufficient as an indicator of pothole hydrology (Leibowitz and Vining 2003). Flows can also reverse on a seasonal basis: an individual pothole can be a discharge wetland in the spring, receiving ground water from uplands, and then become a recharge wetland in summer as evapotranspiration creates a groundwater sink (Winter 1989).

Surface connectivity occurs among some prairie potholes, with topographically lower wetlands receiving inputs from upslope wetlands (Winter 1989, Winter and Rosenberry 1998). In certain areas, surface water connections may occur sporadically when periods of intense rain result in potholes overflowing and forming temporary connections to adjacent ones. Leibowitz and Vining (2003) have coined the term "temporal connectivity" to refer to this phenomenon, and suggest that it be considered not as a presence/absence occurrence, but rather as a probability event. However, they note that 
temporal connectivity is much more likely to exist in the eastern part of the prairie pothole region, which is characterized by relatively flat terrain. In the more rolling prairie landscapes and semiarid climate of the study area, the probability of this temporal surface water connectivity is likely to be distributed over fewer wetlands and a longer period of time. When surface water connections occur, however, they can have an ecologically controlling effect. Surface water flow from larger, upslope wetlands can increase electrical conductivity and salinity (Leibowitz and Vining 2003), both of which are factors controlling the distribution of plants (Stewart and Kantrud 1971) and invertebrates (Euliss et al. 2002) in prairie potholes. The hydrologic functions at a given wetland can sometimes be determined in the field by salinity, or can be identified by vegetation types. Potholes with high salinity tend to be groundwater discharge wetlands. Potholes that are classified as temporarily flooded in the NWI mapping tend to recharge groundwater, while those characterized as seasonally flooded are generally either flow-through or groundwater recharge. Semi-permanently flooded potholes can have either groundwater discharge or flow-through functions (Euliss et al. 2002).

\section{Vegetation and Ecological}

\section{Processes}

Riparian habitats along the Milk, and to a lesser extent, the Marias, are characterized by the oxbow marshes, shrub-dominated terraces, and cottonwood gallery forests generally associated with floodplains. The St. Mary, at higher elevations, is a high gradient river with less floodplain development, and riparian habitats are more characteristically mixed woodland and shrubland. Three species of cottonwood occur: plains cottonwood (Populus deltoides), narrowleaf cottonwood ( $P$. angustifolia), and black cottonwood (P. balsamifera ssp. trichocarpa). In the western portion of the project area, black cottonwood is the dominant riparian tree. Plains cottonwood is the most common species overall, and dominates most stands, although narrowleaf cottonwood is also common.

Central and eastern floodplains can be lush if they are still within reach of high flows. More mesic stands support a well-developed and diverse shrub and small tree layer including boxelder (Acer negundo), peachleaf willow (Salix amygdaloides), yellow willow ( $S$. lutea), red-osier dogwood (Cornus sericea), chokecherry (Prunus virginiana), western snowberry (Symphoricarpos occidentalis), Wood's rose (Rosa woodsii), and silver buffaloberry (Shepherdia argentea). Drier stands on terraces often have no shrub component at all or a less diverse shrub layer dominated by western snowberry or Wood's rose. The native grasses that once characterized these stands, such as western wheatgrass (Pascopyrum smithii) and thickspike wheatgrass (Elymus lanceolatus), have now largely been replaced by exotic pasture grasses, primarily Kentucky bluegrass (Poa pratensis) and smooth brome (Bromus inermis). Grazing has also greatly altered these communities in places by shifting shrub composition to favor less palatable species, such as rose and snowberry.

Tributaries generally have small, narrow floodplains with discontinuous bands of cottonwood. In the central and eastern parts of the study area, these streams usually have broader terraces with silver sage (Artemisia cana) / western wheatgrass communities. Saltgrass (Distichlis spicata), threesquare bulrush (Schoenoplectus pungens), and black greasewood (Sarcobatus vermiculatus) are common along more alkaline streams. In general, small, ephemeral streams have greater year-to-year hydrologic variability than larger rivers, so cottonwood regeneration is highly episodic.

Wetland vegetation is highly variable, depending on wetland type and location. Along the Rocky Mountain Front, fens occur at higher elevations as a mosaic of herbaceous and woody plant communities. In herbaceous communities, several plant associations are dominated by sedges (Carex sp.) and spikerushes (Eleocharis sp.). Bryophyte diversity is generally high and includes sphagnum (Sphagnum sp.). Shrub-dominated carrs are typically composed of willow (Salix sp.) and dwarf birch (Betula nana). The surrounding landscape may be ringed with other wetland systems: fens often grade into marshes, wet meadows or riparian shrublands, and can be surrounded by conifer swamps or wet to mesic coniferous forests. 
Marshes occur in and adjacent to ponds and prairie potholes, as fringes around lakes or oxbows, and along slow-flowing streams and rivers. Marshes are classified as either seasonal or semipermanent based on the dominant vegetation found in the deepest portion of the wetland, as vegetation is representative of the hydroperiod. Semipermanent wetlands are continually inundated with water depths up to 2 meters (6.5 feet). Dominant vegetation includes common threesquare, Nebraska sedge (Carex nebrascensis), broadleaf cattail (Typha latifolia), and hardstem bulrush (Schoenoplectus acutus). Alkaline marsh communities are usually dominated by alkali bulrush (S. maritimus), fresh water cordgrass (Spartina pectinata), and seashore saltgrass.

Depressional wetlands are dynamic systems that developed under climatic conditions where wetdrought cycles in Montana influence the ecological communities in these systems (Hansen et al., 1995). Vegetation communities within these systems are characterized as concentric zones around the deeper portion of the wetland. These bands of vegetation communities follow a hydrologic gradient from low prairie, to wet meadow, then to emergent marsh or open water in the deeper portion of the wetland. The number of zones is dependent on the wet-drought cycle where during drought years there may only be one vegetative zone. Flooding, drawdown and the eventual exposure of mud flats drive the water-level vegetation cycle. Seeds from annuals and perennials germinate and cover exposed mud flats, but when precipitation floods the depressions the annuals drown and the perennials survive. Over a series of years the perennials dominate. The drawdown to mudflats is necessary so that emergent vegetation can become reestablished.

Closed depressions usually feature a drawdown zone dominated by western wheatgrass and foxtail barley (Hordeum jubatum). Povertyweed (Iva axillaris) and willow dock (Rumex salicifolius) occupy the broad, low gradient basins that are shallowly inundated in the spring and draw down every year to reveal bottoms of gray bentonite. Common spikerush (Eleocharis palustris) occurs within the drawdown area where there is more organic matter in the substrate. Hardstem bulrush typifies closed depressions sufficiently deep to remain permanently inundated during most years.

Open depression wetlands often have submerged aquatic plants in the open water zone including common hornwort (Ceratophyllum demersum), short spikewater milfoil (Myriophyllum sibiricum), and horned pondweed (Zannichellia palustris) as well as floating-leaved plants including pondweeds (Stuckenia and Potamogeton sp.), white water crowfoot (Ranunculus aquatilis) and arrowheads (Sagittaria sp.). The central marsh zone is typically dominated by hardstem bulrush, but softstem bulrush (Schoenoplectus tabernaemontani), common threesquare and alkali bulrush, often co-dominate. Also found in the marsh zone are cattails, water knotweed (Polygonum amphibium), and hemlock water parsnip (Sium suave). The seasonally flooded zones are typically dominated by graminoids including common spikerush, needle spikerush (Eleocharis acicularis), American sloughgrass (Beckmannia syzigachne), wheat sedge (Carex atherodes), foxtail barley, shortawn foxtail (Alopecurus aequalis), and water foxtail (A. geniculatus). Open depressional systems are often bordered by wet prairie zones characterized by species such as slimstem reedgrass (Calamagrostis stricta), bluejoint (C. canadensis), clustered field sedge (Carex praegracilis) and fowl bluegrass (Poa palustris). Open depressions with more alkaline or saline water and soil chemistry will typically be bordered by species such as saltgrass, western wheatgrass, and freshwater cordgrass. Sites that have been moderately grazed often have an increase in Baltic rush (Juncus balticus), knotted rush (J. nodosus), foxtail barley, and American sloughgrass. In semi-permanent open depressional systems, the drawdown zone is typically dominated by beaked sedge (Carex utriculata) water sedge ( $C$. aquatilis), and Nebraska sedge.

Saline depressional wetlands are similar, but tend to have brackish water and high salinity, attributed to high evaporation and the accumulation of minerals dissolved in the water. Species that typify this system are salt-tolerant and halophytic graminoids such as alkali bulrush, common three square, inland saltgrass, Nuttall's alkali grass (Puccinellia nuttalliana), foxtail barley, red swampfire (Salicornia 
rubra) and freshwater cordgrass, and shrubs such as black greasewood.

Prairie potholes occur in shallow depressions that were created when ice from receding glaciers were abandoned and melted creating small complexes of depressions. These types of wetlands are ephemeral with standing water only lasting for a few weeks in the spring to early summer but water levels can vary due to seasonal and inter-annual variations (Jones 2003, Van der Kamp et al. 1999). Vegetation in prairie potholes also occurs in concentric zones that follow the hydrologic gradient of the wetland including low prairie, wet meadow, and shallow marsh (Stewart and Kantrud 1971). The types of vegetation that occur in these wetlands are influenced by water duration, salinity, and the surrounding land use (DeKeyser et al. 2003). Dominant vegetation includes spikerush, foxtail barley, and western wheatgrass.

The native upland vegetation ranges from the coolseason perennial bunch grasses and forbs that dominate the Rocky Mountain Front foothills to the mix of short- and mid-grass prairie communities that intermix with shrub steppe in central and eastern portions. Grasses have the greatest canopy cover, and western wheatgrass is usually dominant. Other species include thickspike wheatgrass (Elymus lanceolatus), green needlegrass (Nassella viridula), blue grama (Bouteloua gracilis), and needle and thread (Hesperostipa comata). Near the Canadian border in north-central Montana, this system grades into rough fescue (Festuca campestris) and Idaho fescue (F. idahoensis) grasslands. Steppe vegetation is the result of a semi-arid continental climate where the highly variable precipitation favors shallow-rooted herbaceous perennial grasses and deeprooted shrubs over forests or woodlands. Shrub steppe vegetation is characterized by open stands of silver sagebrush or Wyoming big sagebrush (Artemisia tridentata ssp. wyomingensis) over an herbaceous layer dominated by western wheatgrass, blue grama or needle-and-thread. The co-occurrence of short- and mid-grass prairies is also due to climatic variability. Shorter, drought-resistant grasses such as blue grama increase in abundance during times of drought. Mid-grasses, such as the rhizomatous western wheatgrass and the bunch-forming prairie junegrass (Koeleria macrantha) and needle-andthread, increase under more favorable moisture conditions.

\section{Animal Communities}

Wetlands, particularly prairie potholes, are widely recognized for their significance as critical breeding habitat for waterfowl (Batt et al. 1989). Wetlands also support a diverse assemblage of water dependent birds including Montana species of concern such as the Black-crowned Night-Heron (Nycticorax nycticorax), White-faced Ibis (Plegadis chihi), Franklin's Gull (Larus pipixcan), Common Tern (Sterna hirundo), Forster's Tern (S. forsteri), American White Pelican (Pelecanus erythrorhynchos), and Black Tern (Chlidonias niger). Amphibian species of concern within the project area include the northern leopard frog (Rana pipiens), plains spadefoot (Spea bombifrons), and great plains toad (Bufo cognatus). The western hognose snake (Heterodon nasicus) is also a wetland-dependent species insofar as it feeds on toads, themselves dependent on standing water during part of their life cycle.

The small mammal community in prairie wetlands in Montana is primarily composed of five species: masked shrew (Sorex cinereus), muskrat (Ondatra zibethicus), thirteen-lined ground squirrel (Spermophilus tridecemlineatus), deer mouse (Peromyscus maniculatus), and meadow vole (Microtus pennsylvanicus), all important food sources for prairie predators. The heavier vegetation cover natural to pothole wetlands serves as a population reservoir for small mammals. Bats are also dependent in some part on wetlands, as obligate insectivores, and on the roosting sites found in cottonwood forests.

Wetlands and riparian areas are also important habitat for larger mammals including red fox (Vulpes vulpes), coyote (Canis latrans), raccoon (Procyon lotor), mink (Mustela vison), weasels (Mustela spp.), striped skunk (Mephitis mephitis), and deer (Odocoileus spp.). Whitetail deer (O. virginianus) are abundant in the riparian corridor along the rivers. In recent years, grizzly bears (Ursus arctos) have expanded their range across the study area, and have been found as far east as the confluence of the Marias and Missouri Rivers. 


\section{Methods}

\section{Site Selection}

We used wetland polygons mapped by the NWI in the 1980 's to generate a pool of potential sample sites (i.e., the sample frame) for random site selection. We stratified sites by Level IV ecoregion to maximize within-ecoregion similarities and minimize between-region variability in vegetation, geology, and climate (Van Sickle and Hughes 2000). The sample frame included all palustrine wetland types mapped by the NWI. The survey design followed a Generalized Random Tessellation Stratified (GRTS) procedure for discrete objects with reverse hierarchical randomization (Stevens 1997). All 161,003 NWI polygons within the sample frame were treated as the discrete objects with locations identified by the wetland polygon centroid. The GRTS design was selected because it creates a spatially balanced sample among randomly selected sites (Stevens and Olsen 1999, Stevens and Olsen 2004). This approach can account for the spatial patterning inherent in ecological systems (i.e., sites in close proximity tend to be more similar than widely separated sites). Spatially balanced sampling is also more efficient than simple random sampling because it can minimize the redundancy inherent in a simple random sample, which might select multiple proximate sites (Stevens and Jensen 2007). An unequal probability stratified survey design was then used to select sample sites stratified by Level IV ecoregion (Omernik 1987). The number of sites selected within each Level IV ecoregion was proportional to the area of each ecoregion within the project area.

Sixty-six percent $(10,344,286$ acres) of the Milk, Marias, and St. Mary project area is in private ownership. To ensure that wetlands on the remaining $34 \%(5,457,880$ acres $)$ publicly owned lands were included in our sample frame, two subpopulations were identified where approximately $50 \%$ of the selected wetlands occurred on privately owned lands and $50 \%$ occurred on public land. A total of 1,314 wetlands were selected from the NWI based sample frame with a $50 \%$ oversample to account for wetlands that no longer existed or were inaccessible due to denied access by private landowners.
For the Level 1 landscape analysis, all 1,314 wetland points were included. To select sites for the Level 2 rapid wetland field assessments, we used a two-stage approach. First, to determine if the wetland polygons mapped in the 1980's still existed, each sample site was visually examined in ArcMap 9.3 (ESRI 2008) using $1 \mathrm{~m}$ resolution aerial imagery taken in 2005 by the National Agricultural Imagery Program (NAIP). We determined land ownership for each wetland polygon from the original Level 1 site selection by spatially joining the NWI polygon centroid and cadastral land ownership data (Montana Department of Administration 1999). To ensure access to sites on private land, we contacted property owners by telephone or occasionally in person. If permission was denied, the site was dropped and the next accessible site was evaluated until the sample size included 123 wetlands proportionately distributed across the four Level IV ecoregions. We conducted Level 3 vegetation assessments on 44 of the Level 2 assessment sites. Sites for the intensive assessments were selected in the field based on vegetation characteristics.

\section{Data Collection \\ Wetland Landscape Profile}

Certain wetland types may perform certain functions better than other wetland types (Brinson 1993, Johnson 2005). For example, wetlands located in floodplains tend to have a high sediment retention function while wetland flats have a low sediment retention function. The ability of wetlands to effectively perform certain functions depends upon vegetation, landscape position, water source, and hydrodynamics (Brinson 1993). Cumulative impacts to wetlands within watersheds will have significant additive effects (Johnson 2005). Therefore, it is important to identify the type and location of wetland resources within a given watershed.

Wetland profiles provide information on the distribution and characteristics of wetlands within a watershed. We prepared landscape profiles using all the 161,003 mapped palustrine wetland polygons and ancillary data sources to summarize these and other attributes for fourth, fifth, and sixth code 
hydrologic units. We supplemented the Cowardin wetland classification, which describes the system, dominant vegetation type, and water regime, with a hydrogeomorphic attribute that describes a wetland in terms of its landscape position and hydrology. This attribution allows wetland type to be associated with a wetland function. We calculated five metrics to produce the wetland profiles: 1) Density of wetlands, calculated as the total number of palustrine wetlands divided by total land acres within a given hydrologic unit; 2) Number and acreage of wetland types by Cowardin class, water regime and hydrogeomorphic type and code; 3) Percentage of wetlands on private, state, federal, and tribal lands; 4) Percentage of wetlands protected through conservation easements or land management based on the Protected Areas Database (Data Basin 2010); and 5) Percentage of altered wetlands (defined as those wetlands mapped with a "impounded" or "excavated" modifier).

\section{Level 1 Landscape Analysis}

A Level 1 landscape analysis was used to characterize potential landscape level disturbances at three spatial scales (100 meters, 300 meters, and 1,000 meters) from the wetland perimeter using the buffering and identify functions in ArcGIS.
Landscape level indicators of disturbance were derived from available digital datasets including land cover/land use, hydrology, and roads (Appendix C). Given the lack of detailed up-to-date spatial data on livestock grazing and resource extraction, the $1 \mathrm{~m}$ resolution NAIP aerial imagery was examined for evidence of either disturbance. Four major attributes were considered as possible sources of anthropogenic stressors: roads, hydrological modifications, land cover/land use type, and resource use. We evaluated and scored each attribute based on multiple metrics (Table 1). We assigned a rating to each metric for roads, hydrological disturbances, and resource use based upon its distance from the wetland or buffered wetland perimeter. For land cover/land use, metric ratings were assigned based upon the percent cover of each land cover type within the wetland polygon or wetland buffer. Disturbance ratings increased with either decreasing distance from the disturbance or increasing percent cover of each land cover type.

To calculate an overall Level 1 site score, we multiplied individual metrics by a given weight and then summed into an overall attribute score (Appendix C). The four attribute scores were then weighted and summed again to achieve a final site score.

Table 1. The Montana Natural Heritage Program Rapid Assessment Method attributes and component metrics.

\begin{tabular}{ll}
\hline Attribute & Metric \\
\hline Landscape Context & Landscape Connectivity \\
& Buffer Width \\
& Buffer Length \\
& Buffer Condition \\
Size & Wetland Size Relative to Historic Conditions \\
Biotic Structure and Composition & Relative Cover of Native Plant Species \\
& Relative Cover of Tolerant Native Plant Species \\
& Cover of Noxious Plant Species \\
& Organic Matter Accumulation \\
& Patch Interspersion \\
Hydrology & Water Source \\
& Hydroperiod \\
& Hydrologic Connectivity \\
Physicochemical & Soil Surface Integrity \\
& Water Quality \\
\hline
\end{tabular}




\section{Level 2 Rapid Assessments}

We completed 123 Level 2 rapid wetland assessments. Field ecologists used the Montana Ecological Integrity Assessment (EIA) form (Appendix D) developed by the MTNHP to assess wetland condition for all wetland types within the project area. The EIA approach uses a set of ecological attributes that reflect both the structure and function of the wetland to assess ambient condition (Table 1). Each ecological attribute contains one or more indicators to represent the status or trend of the attribute. These indicators are measured by metrics that include narrative ratings scaled along a gradient of wetland condition status. Each metric consists of three to five narrative statements that are assigned an ordinal scale value. Higher numbers correspond with increasing levels of disturbance. Each metric rating is summarized into an overall attribute score for five attributes: 1) Landscape Context; 2) Relative Patch Size; 3) Biotic; 4) Physicochemical; and 5) Hydrology. The ratings for these five attributes are then combined to produce an overall EIA condition score (Collins et al. 2004; Appendix E).

At each sample point, we established a 0.5 hectare assessment area (AA). The AA is the boundary of the wetland (or a portion of the wetland) targeted for sampling and analysis and is defined as all wetland area of the same ecological system type within a 0.5 hectare area around the sample point. If the wetland was smaller than 0.5 hectares and included a single ecological system, the entire wetland was assessed. In wetlands where several ecological systems occurred, the center of the AA was adjusted up to 50 meters so that the AA consisted of only one ecological system.

Once the AA was defined, we recorded general site characteristics (e.g., elevation, soil drainage, topographic position, amount of the AA covered by standing water, HGM class, and Cowardin system). We also collected soils data at each site by excavating two 45-60 cm deep soil cores in representative areas of the AA. For each soil layer, the depth, texture, matrix color, and abundance and color of redoximorphic features were recorded. Soil colors were determined using Munsell Soil Color Charts
(USDA Natural Resources Conservation Service 2006; Munsell Color Company 2000).

The EIA form also contains a stressors checklist developed by the MTNHP. Stressors on the checklist include paved roads, developed buildings, mining activity, agriculture, and logging within 500 meters of the AA perimeter and within the AA. Stressors to wetland hydrology within 500 meters of the AA include impoundments, pumps, diversions, and dikes. Observed stressors were tallied to create a disturbance gradient. We assumed that a wetland with more stressors present will be more impaired than a wetland with no or few stressors (Miller and Wardrop 2006).

\section{Level 3 Intensive Assessments}

The MTNHP EIA method uses vegetation as an intensive biological measure to assess wetland condition (see Appendix F for field form) and to validate both the Level 1 landscape analysis and the Level 2 rapid assessments (Wardrop et al. 2007). Vegetation was selected because wetland plants are generally good indicators of the cumulative impacts of disturbances on wetland condition (Cronk and Fennessy 2001). In addition, vegetation can be assessed in all types of wetlands, including those that only have standing water seasonally, whereas indicators such as water chemistry, diatoms, and macroinvertebrates require standing water for most or all of the growing season.

Intensive Level 3 vegetation data were collected at 44 of the Level 2 sites using a 20 m x 50 m relevé plot (Peet et al. 1998). The structure of the plot consists of ten $10 \mathrm{~m}$ x $10 \mathrm{~m}\left(100 \mathrm{~m}^{2}\right)$ modules typically arranged in a 2 x 5 array (Appendix G). The plot was subjectively placed within the AA to maximize abiotic/biotic heterogeneity and to capture micro-site variations produced by hummocks, water tracks, side-channels, pools, wetland edge, and microtopography. The absolute cover of all vascular species within four of the $100 \mathrm{~m} 2$ modules was estimated using the cover classes developed by Peet et al. (1998; Appendix G). The area covered by standing water, bare ground, litter and bryophytes was also estimated for each module. Cover class midpoints were used to calculate average cover values over the entire relevé plot for each taxon. 
For Level 3 assessment sites, multiple vegetation metrics were used to conduct a Floristic Quality Assessment (FQA). Previous studies have demonstrated that the FQA is a good predictor of wetland condition (Lopez and Fennessy 2002, DeKeyser et al. 2003, Jones 2004, Hargiss et al. 2008). A FQA accounts for the presence of exotic species, the richness of native species, and an individual plant species' tolerance and sensitivity to disturbance (Cronk and Fennessy 2001, Miller and Wardrop 2006). Similar indices of plant community integrity have been used in wetlands in the Prairie Pothole region of North Dakota and found to be robust in assessing the influence of anthropogenic and natural disturbances on plant communities (Hargiss et al. 2008). However, it is recommended that when developing indices for plant communities in this region, wetlands be separated by their hydrologic regime (Hargiss et al. 2008). For this reason Level 3 results for temporarily, seasonally, and semi-permanently flooded wetlands were analyzed separately.

\section{Data Analysis}

Descriptive statistics were generated for all Level 1,2 , and 3 data, and the range and distribution of each metric were examined using frequency histograms. We calculated Spearman's correlation coefficients to analyze relationships among and between metric and attribute scores for each level of assessment. Level 1 data from the landscape analysis were compared to Level 3 vegetation data to assess the relationships between disturbances in the surrounding landscape and wetland condition in the project area. All statistical analyses were conducted in R 2.10.1 (R Core Development Team 2009). Correlations were considered significant at $\mathrm{p} \leq 0.05$. Correlations were ranked as: strong ( $\mathrm{r}>$ 0.5 ); moderate (0.4 and 0.5 ); or weak (less than $\mathrm{r}<$ 0.4) (Hychka et al. 2007).

For the FQA, we assigned Coefficients of Conservatism (C-values) ranging from 0 to 10 to all plants identified to species (Northern Great Plains Floristic Quality Assessment Panel 2001). C-values were assigned as:

9-10: Native species that exhibit a high degree of ecological specificity.
7-8: Native species typical of well established communities that have minimal disturbance.

4-6: Native species found in certain wetland systems that can tolerate moderate disturbance.

1-3: Widespread native species that occur in a variety of communities and are common in disturbed sites.

0: $\quad$ Exotic species

Metrics in the FQA include native species richness, non-native species richness, total species richness, mean $\mathrm{C}$-value of all plants, mean $\mathrm{C}$-value of just native plants, and a cover weighted mean $\mathrm{C}$-value for both native species and total species and a Floristic Quality Index (see Appendix $\mathrm{H}$ for complete list of formulas). Lower FQI and mean $\mathrm{C}$-values indicate that the site is dominated by plants that are frequently found in disturbed areas while higher values indicate a greater floristic quality (Lopez and Fennessy 2002). Although the FQI is computed only for native species, it is also useful to calculate an FQI that includes non-native species, as their presence in a site is often a response to a disturbance (Lopez and Fennessy 2002, Miller and Wardrop 2006, Bourdaghs et al. 2006, Milburn et al. 2007).

The depressional and pothole wetlands found in the study area are inherently species poor. Typically, the FQI is sensitive to species richness, so speciespoor sites will receive a lower FQI value despite being in or close to a natural state. Therefore, we calculated an adjusted FQI (Miller and Wardrop 2006) that incorporates a "maximum attainable FQI score" based on the highest possible value as well as both native and non-native species scores, into the final index.

A cover-weighted FQI was also calculated using the relative average cover of a species in the entire plot as a weighting factor (Milburn et al. 2007). This cover-weighted FQI was also calculated for native species alone, and for the adjusted FQI. A cover-weighted adjusted FQI was also produced for each site using the relative average cover of a species in the entire plot as a weighting factor 
(Milburn et al. 2007). Refer to Appendix H for formulas.

We predicted the response of vegetation metrics to increasing human disturbance to test the assumptions supported in published wetland research (Table 2). Using Spearman rank correlation analy- sis we compared the observed relationship between Level 1 landscape level metrics and the Level 3 FQA metrics with expected relationships. Correlation results between Level 1 metrics and FQA indices in the expected direction (positive or negative) were interpreted as an indication of responsiveness to human disturbance (Stein et al. 2009).

Table 2. Predicted responses of vegetation metrics to increasing levels of human disturbance.

\begin{tabular}{lc}
\hline Vegetation Metric & $\begin{array}{c}\text { Predicted Response to Increasing Human } \\
\text { Disturbance }\end{array}$ \\
\hline Non-Native Richness & Increase \\
Native Richness & Decrease \\
Total Richness & Decrease \\
$\%$ Natives & Decrease \\
$\%$ Non-natives & Increase \\
Mean C & Decrease \\
Mean C Nat & Decrease \\
Cover-Weighted Mean C & Decrease \\
Cover-Weighted Mean C of Natives & Decrease \\
FQI all species & Decrease \\
FQI & Decrease \\
Adjusted FQI & Decrease \\
Adjusted Cover-Weighted FQI & Decrease \\
\hline
\end{tabular}




\section{Results}

\section{Wetland Landscape Profile \\ Results}

The project area includes 22 4th code hydrologic units equaling 15,794,321 acres. Of the total, $10,344,286$ acres are private and 5,457,886 acres are public. The dominant ecological systems include an upland matrix of cultivated crops $(32,723$ acres), Northwestern Great Plains Mixedgrass Prairie (29,216 acres), and Introduced Upland Vegetation - Annual and Biennial Forbland (13,912 acres). Complete tables and maps for the wetland landscape profile for fifth and sixth code hydrologic units are included in Appendix I.

\section{Wetland Density}

Based on 1980s NWI mapping, wetland and riparian areas are more concentrated between Havre and Malta and in the watersheds located in the southwestern portion of the study area (Figure 4). Wetland density is similar, with watersheds around Malta and Havre having the greatest density of wetlands followed by the watersheds west of Cut Bank (Figure 5). The Wild Horse Lake watershed had the highest wetland density, followed by the Battle Creek and Cottonwood Creek watersheds.

\section{Number and Acreage of Wetland Types}

The majority of wetlands in the project area are freshwater emergent wetlands with a temporarily or seasonally flooded water regime (Table 3 ). Wetlands associated with riverine systems are the dominant hydrogeomorphic type; these are through-flow basins associated with lotic systems. Wetlands are considered to have a riverine HGM type if they are located within 100 meters of a perennial or intermittent stream and 20 meters of

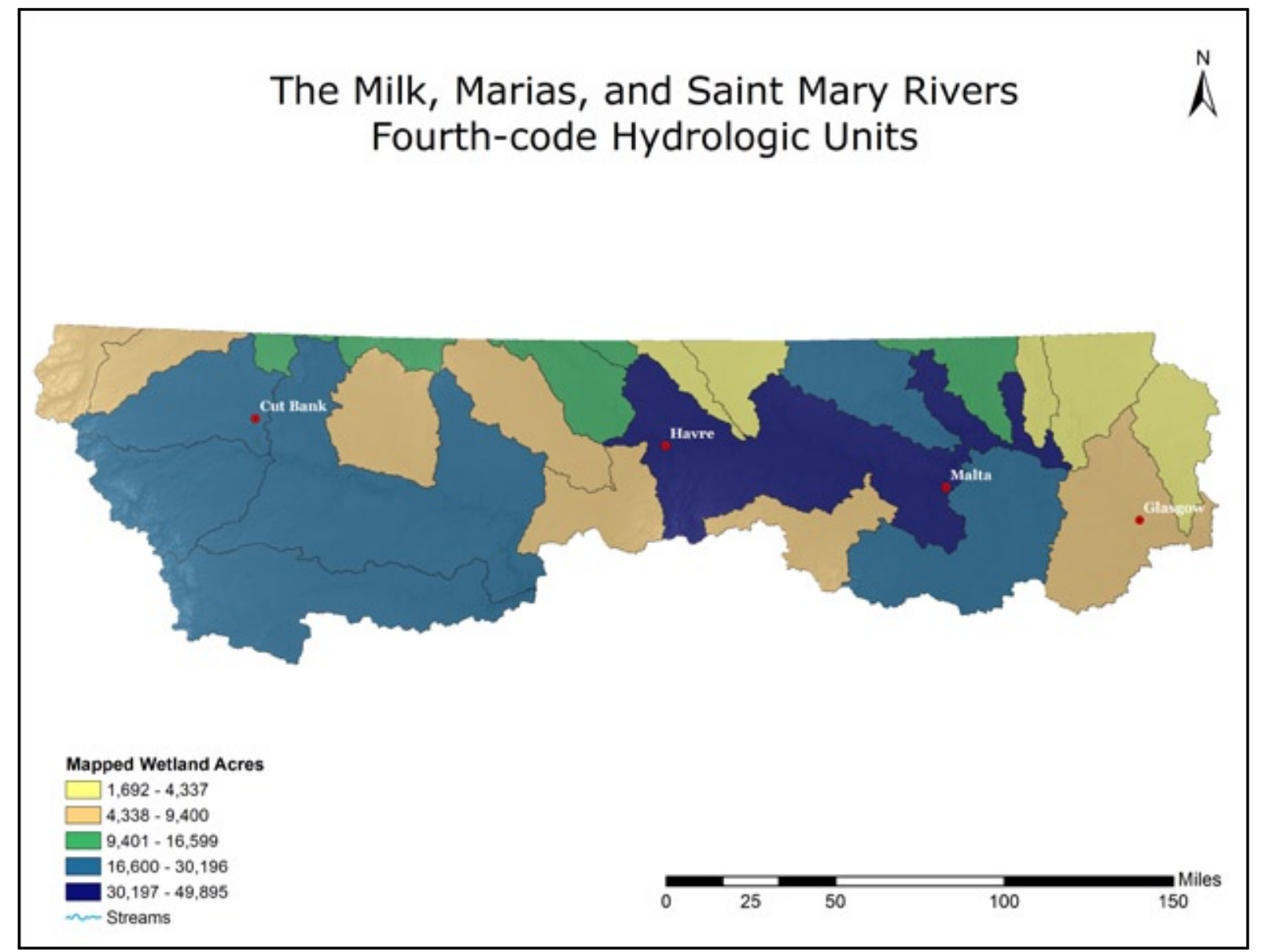

Figure 4. Acres of mapped wetlands within the project area. 


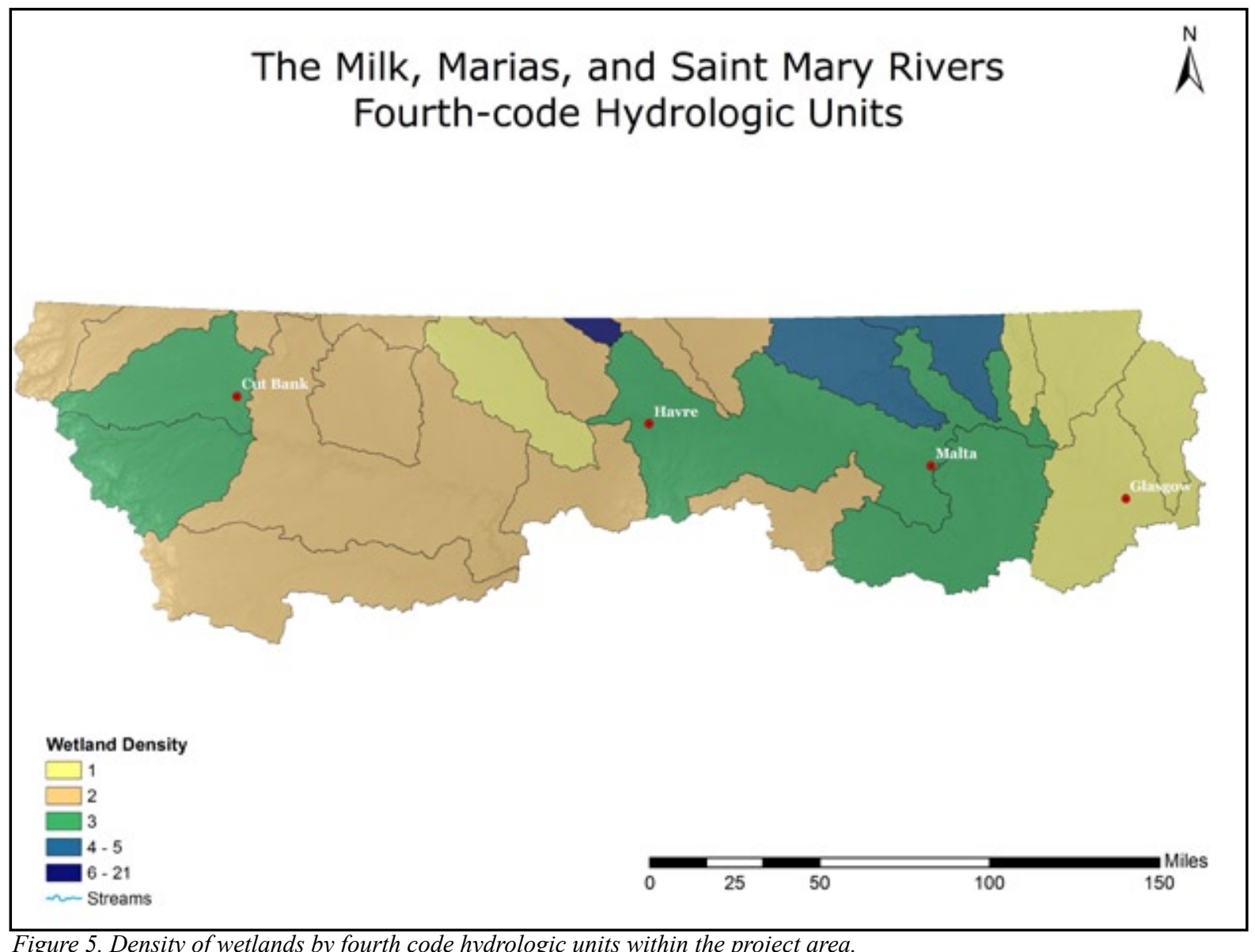

an ephemeral stream. The second most common hydrogeomorphic type for wetlands in the project area is depressional.

\section{Percentage of Wetlands on Private, Public, and Tribal Land}

Most wetlands in the project area are located on private land (Table 4). In some watersheds, including Wild Horse Lake, Sage Creek, and Willow Creek, wetlands occur almost exclusively on private land (Figure 6). Wetlands in other watersheds, including the Milk River Headwaters and Cut Bank Creek, are mostly on tribal lands. Only a small percentage of wetlands in each watershed are on state or federal land.

\section{Percentage of Protected Wetlands}

The percentage of wetlands protected through conservation easements or land management was calculated for each watershed based on the Protected Areas Database of the United States (Table 4).
Based on the information in the database, wetlands within the Wild Horse Lake, Battle Creek, and Whitewater Creek watersheds are all considered protected. Other watersheds with a high percentage of protected wetlands include Cut Bank Creek, Milk River Headwaters, and Peoples Creek. However, it should be noted that the database characterizes public lands managed for natural resource use (e.g., grazing) as protected.

\section{Percentage of Altered Wetlands}

We calculated the percentage of altered wetlands using the impounded and excavated modifiers from the NWI Cowardin wetland classification attributes (Table 4). The wetland profile indicates that in the Battle Creek, Lower Milk River, and the Rock Creek watersheds, the percentage of altered wetlands exceeds the percentage of natural wetland types (Figure 7). 
Table 3. Summary table of number, acres and percentage of total wetland acres by Cowardin classification water regime and class and associated hydrogeomorphic type and code.

\begin{tabular}{|c|c|c|c|}
\hline Water Regime & $\begin{array}{c}\text { \# of } \\
\text { Polygons }\end{array}$ & Acres & $\begin{array}{c}\text { \% of Total Wetland } \\
\text { Acres }\end{array}$ \\
\hline Temporarily Flooded & 89,944 & 161,211 & $53 \%$ \\
\hline Saturated & 3,938 & 23,885 & $8 \%$ \\
\hline Seasonally Flooded & 41,295 & 78,905 & $26 \%$ \\
\hline Semipermanently Flooded & 19,675 & 36,357 & $12 \%$ \\
\hline Intermittently Exposed & 6,015 & 3,441 & $1 \%$ \\
\hline Class & $\begin{array}{c}\text { \# of } \\
\text { Polygons }\end{array}$ & Acres & $\begin{array}{c}\text { \% of Total Wetland } \\
\text { Acres }\end{array}$ \\
\hline Freshwater Emergent Wetland & 129,091 & 246,634 & $81 \%$ \\
\hline Freshwater Forested/Shrub Wetland & 4,036 & 20,704 & $7 \%$ \\
\hline Freshwater Pond & 24,787 & 31,227 & $10 \%$ \\
\hline Freshwater Pond Shore & 3,097 & 5,590 & $2 \%$ \\
\hline Hydrogeomorphic (HGM) Type & $\begin{array}{c}\text { \# of } \\
\text { Polygons }\end{array}$ & Acres & $\begin{array}{c}\text { \% of Total Wetland } \\
\text { Acres }\end{array}$ \\
\hline Depressional & 89,105 & 101,400 & $33 \%$ \\
\hline Lacustrine & 411 & 3,829 & $1 \%$ \\
\hline Riverine & 55,314 & 187,350 & $61 \%$ \\
\hline Slope & 16,817 & 12,195 & $4 \%$ \\
\hline Hydrogeomorphic (HGM) Code & $\begin{array}{c}\text { \# of } \\
\text { Polygons }\end{array}$ & Acres & $\begin{array}{c}\% \text { of Total Wetland } \\
\text { Acres }\end{array}$ \\
\hline Lentic Basin Through Flow (LE3BATH) & 184 & 2,607 & $1 \%$ \\
\hline Lotic River Floodplain Through Flow (LRFPTH) & 1,155 & 4,323 & $1 \%$ \\
\hline Lotic Stream Basin Through Flow (LSBATH) & 51,318 & 155,446 & $51 \%$ \\
\hline Lotic Stream Fringe Through Flow (LSFRTH) & 2,499 & 26,149 & $9 \%$ \\
\hline Terrene Basin Complex (TEBACO) & 15,253 & 31,959 & $10 \%$ \\
\hline Terrene basin Isolated (TEBAIS) & 73,852 & 69,440 & $23 \%$ \\
\hline Terrene Slope Complex (TESLCO) & 2,201 & 3,191 & $1 \%$ \\
\hline Terrene Slope Isolated (TESLIS) & 14,616 & 9,003 & $3 \%$ \\
\hline
\end{tabular}


Table 4. Wetland landscape profiling of palustrine wetlands within each fourth code hydrological unit (HUC).

\begin{tabular}{lcccccccc}
\hline & HUC & & & & & & & \\
4th Code HUC Name & Number & Private & State & Federal & Tribal & Protected & Natural & Altered \\
\hline Saint Mary River & 10010002 & $0 \%$ & $0 \%$ & $25 \%$ & $75 \%$ & $81 \%$ & $97 \%$ & $3 \%$ \\
Two Medicine River & 10030201 & $18 \%$ & $0 \%$ & $20 \%$ & $61 \%$ & $66 \%$ & $98 \%$ & $2 \%$ \\
Cut Bank Creek & 10030202 & $7 \%$ & $0 \%$ & $1 \%$ & $92 \%$ & $79 \%$ & $97 \%$ & $3 \%$ \\
Marias River & 10030203 & $91 \%$ & $3 \%$ & $6 \%$ & $0 \%$ & $35 \%$ & $76 \%$ & $24 \%$ \\
Willow Creek & 10030204 & $90 \%$ & $8 \%$ & $2 \%$ & $0 \%$ & $13 \%$ & $72 \%$ & $28 \%$ \\
Teton River & 10030205 & $67 \%$ & $19 \%$ & $14 \%$ & $0 \%$ & $53 \%$ & $86 \%$ & $14 \%$ \\
Milk River Headwaters & 10050001 & $0 \%$ & $0 \%$ & $0 \%$ & $100 \%$ & $74 \%$ & $97 \%$ & $3 \%$ \\
Upper Milk River & 10050002 & $68 \%$ & $5 \%$ & $28 \%$ & $0 \%$ & $49 \%$ & $78 \%$ & $22 \%$ \\
Wild Horse Lake & 10050003 & $99 \%$ & $0 \%$ & $0 \%$ & $0 \%$ & $100 \%$ & $99 \%$ & $1 \%$ \\
Middle Milk River & 10050004 & $76 \%$ & $6 \%$ & $11 \%$ & $7 \%$ & $57 \%$ & $80 \%$ & $20 \%$ \\
Big Sandy Creek & 10050005 & $85 \%$ & $4 \%$ & $3 \%$ & $8 \%$ & $49 \%$ & $83 \%$ & $17 \%$ \\
Sage Creek & 10050006 & $94 \%$ & $6 \%$ & $0 \%$ & $0 \%$ & $13 \%$ & $73 \%$ & $27 \%$ \\
Lodge Creek & 10050007 & $85 \%$ & $8 \%$ & $7 \%$ & $0 \%$ & $24 \%$ & $56 \%$ & $44 \%$ \\
Battle Creek & 10050008 & $72 \%$ & $8 \%$ & $20 \%$ & $0 \%$ & $100 \%$ & $46 \%$ & $54 \%$ \\
Peoples Creek & 10050009 & $24 \%$ & $6 \%$ & $1 \%$ & $68 \%$ & $83 \%$ & $77 \%$ & $23 \%$ \\
Cottonwood Creek & 10050010 & $77 \%$ & $4 \%$ & $19 \%$ & $1 \%$ & $66 \%$ & $96 \%$ & $4 \%$ \\
Whitewater Creek & 10050011 & $57 \%$ & $4 \%$ & $38 \%$ & $1 \%$ & $100 \%$ & $93 \%$ & $7 \%$ \\
Lower Milk River & 10050012 & $55 \%$ & $5 \%$ & $31 \%$ & $9 \%$ & $58 \%$ & $47 \%$ & $53 \%$ \\
Frenchman Creek & 10050013 & $82 \%$ & $8 \%$ & $9 \%$ & $0 \%$ & $27 \%$ & $78 \%$ & $22 \%$ \\
Beaver Creek (Milk River) & 10050014 & $68 \%$ & $3 \%$ & $27 \%$ & $2 \%$ & $77 \%$ & $76 \%$ & $24 \%$ \\
Rock Creek & 10050015 & $51 \%$ & $4 \%$ & $45 \%$ & $0 \%$ & $73 \%$ & $49 \%$ & $51 \%$ \\
Porcupine Creek & 10050016 & $37 \%$ & $12 \%$ & $4 \%$ & $47 \%$ & $37 \%$ & $82 \%$ & $18 \%$ \\
\hline
\end{tabular}




\section{The Milk, Marias, and Saint Mary Rivers Fourth-code Hydrologic Units}

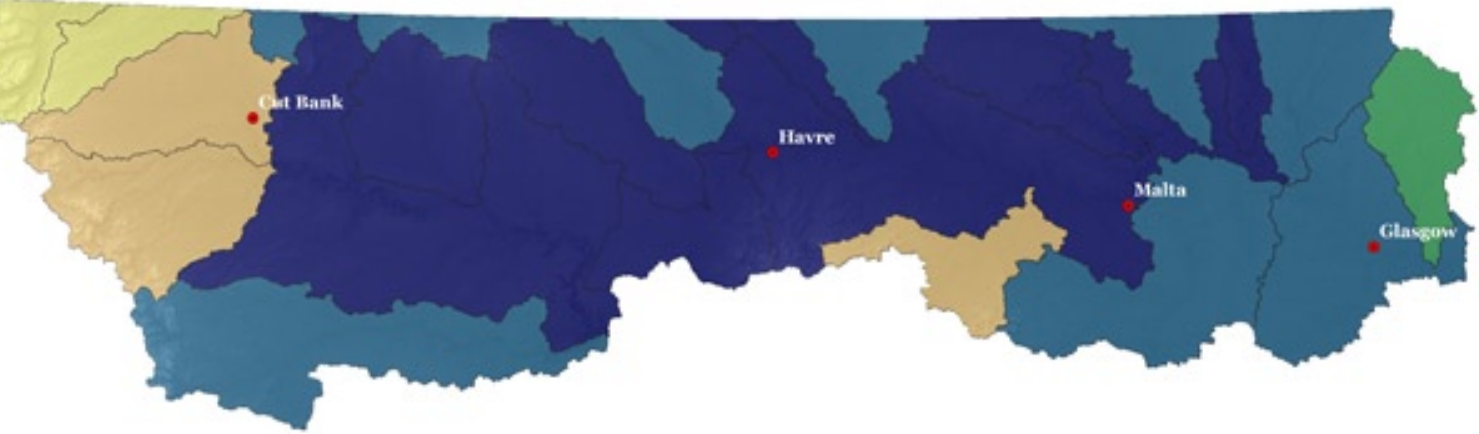

Percent of Wetlands on Private Land

$\square 0 \%$

$\square 1 \%-25 \%$

$\square 26 \%-50 \%$

$51 \%-75 \%$

$76 \%-100 \%$

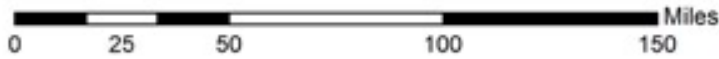

$\sim$ Streams

Figure 6. Percent of wetlands in the project area that are located on private land. 


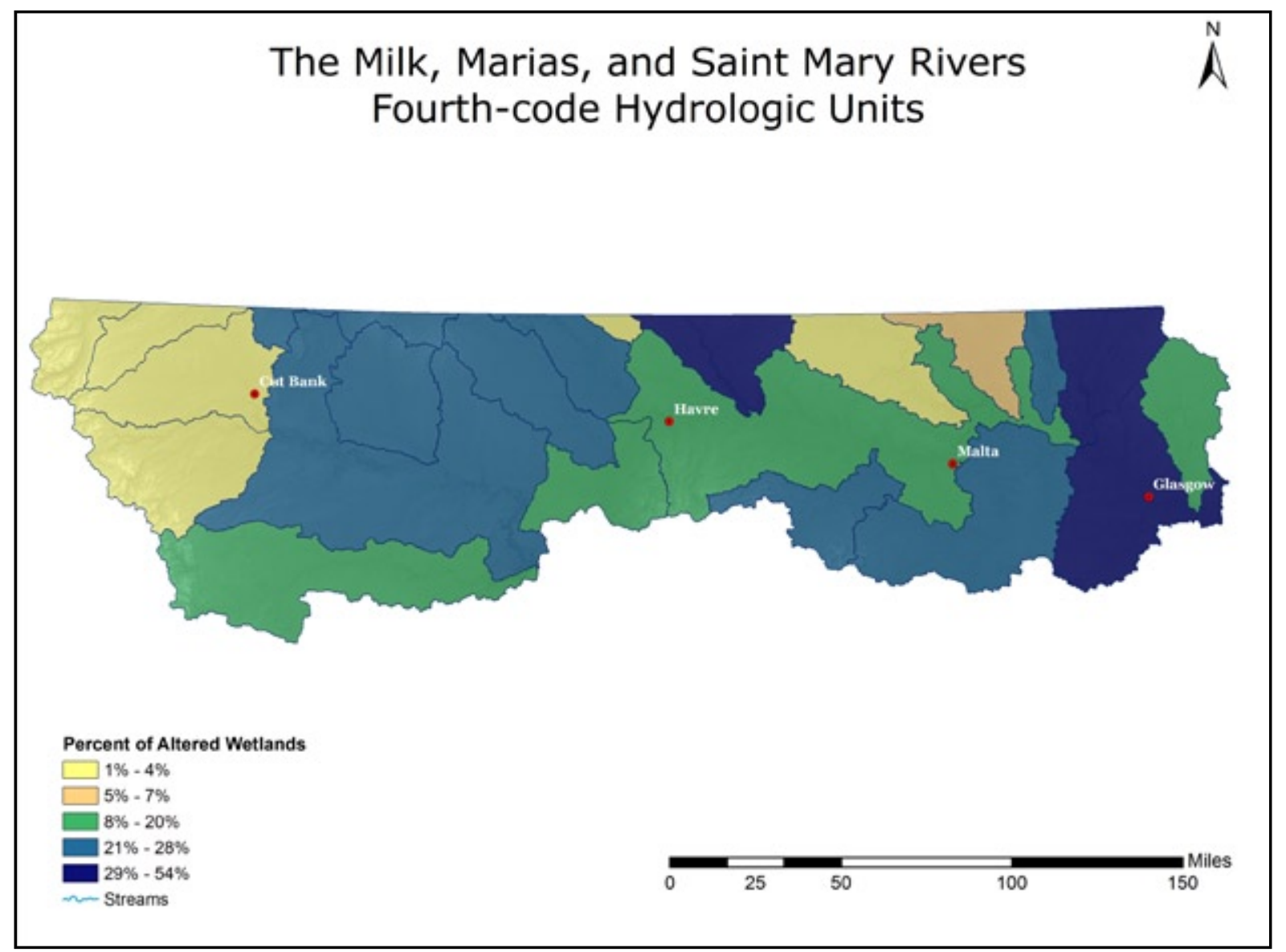

Figure 7. Percent of wetlands in the project area that are considered altered. Determination was made using Cowardin classification modifiers for impounded and excavated wetlands.

\section{Level 1 Landscape Analysis Results}

The Level 1 landscape analysis was conducted on 1,314 wetlands throughout the project area at three different spatial scales $(100,300$, and 1,000 meters; Table 5). Sites with scores near one indicate little to no disturbance while increasing scores indicate increasing landscape disturbances. In general, landscape metrics showed little variability across all three spatial scales. Individual metric scores and overall attribute scores for most disturbance categories were clustered around one; however, transportation scores exhibited the greatest variability (Appendix J). The Local Roads metric had the highest mean scores within the Overall Roads attribute and among all of the metrics included in the Level 1 analysis, suggesting that they may influence the landscape context within the project area. The scores for this metric increased with increasing spatial scale. The Crop/Agriculture metric had the highest mean scores out of all the metrics within the Land Cover attribute and did increase with an increasing spatial scale. Wells scored the highest within the Hydrologic Disturbance Attribute, and Mines/Gravel Pits scored the highest within the Resource Use attribute. However, scores were similar at all three spatial scales for both metrics. The standard deviations around the mean for all metrics indicate that there is overlap between metric and attribute scores at all three spatial scales.

\section{Level 2 Rapid Assessment Results}

A total of 123 Level 2 wetland assessments were conducted during the summer of 2009 (Figure 8). The number of Level 2 sites by ecological system, Level IV Ecoregion, 4th code hydrological unit, and hydrogeomorphic type (HGM) are summarized in Table 6. Wetland assessment sites occurred in 6 of the 4th code HUCs, with most sites falling within the Milk River and Missouri-Marias wa- 
Table 5. Mean Level 1 scores for landscape metrics, attributes and overall site score with standard deviations (S.D.).

\begin{tabular}{lcccccc}
\hline & \multicolumn{2}{c}{$\mathbf{1 0 0} \mathbf{~ m}$ Buffer } & \multicolumn{2}{c}{ 300 $\mathbf{~ m}$ Buffer } & \multicolumn{2}{c}{$\mathbf{1 0 0 0} \mathbf{~ m ~ B u f f e r ~}$} \\
\hline & Mean & S.D. & Mean & S.D. & Mean & S.D. \\
\hline Four wheel drive & 1.24 & 0.63 & 1.37 & 0.77 & 1.58 & 0.90 \\
Local & 2.10 & 1.33 & 2.52 & 1.41 & 3.33 & 1.21 \\
Highway & 1.14 & 0.68 & 1.19 & 0.80 & 1.33 & 1.08 \\
Transportation Score & 1.49 & 0.62 & 1.68 & 0.70 & 2.07 & 0.77 \\
Medium Density & 1.00 & 0.09 & 1.00 & 0.06 & 1.00 & 0.06 \\
Low Density & 1.02 & 0.18 & 1.01 & 0.07 & 1.01 & 0.07 \\
Open Development & 1.04 & 0.23 & 1.02 & 0.15 & 1.00 & 0.05 \\
Crop/Agriculture & 1.95 & 1.59 & 2.15 & 1.65 & 2.49 & 1.69 \\
Hay/Pasture & 1.92 & 1.56 & 1.07 & 0.40 & 1.70 & 1.26 \\
Land Cover Score & 1.43 & 0.70 & 1.36 & 0.50 & 1.55 & 0.50 \\
Ditches & 1.08 & 0.38 & 1.11 & 0.44 & 1.18 & 0.56 \\
Wells & 1.20 & 0.59 & 1.22 & 0.61 & 1.26 & 0.71 \\
Reservoirs & 1.01 & 0.10 & 1.02 & 0.17 & 1.08 & 0.39 \\
Hydrology Score & 1.11 & 0.26 & 1.12 & 0.27 & 1.18 & 0.34 \\
Livestock & 1.12 & 0.56 & 0.92 & 0.80 & 1.18 & 0.72 \\
Mines/Gravel pits & 1.90 & 0.99 & 1.99 & 1.00 & 1.99 & 1.00 \\
Resource Use Score & 1.39 & 0.49 & 1.29 & 0.52 & 1.47 & 0.58 \\
Overall Level 1 Score & 1.38 & 0.31 & 1.40 & 0.32 & 1.62 & 0.37 \\
\hline
\end{tabular}

tersheds. The dominant ecological system represented by assessed wetlands was the Western Great Plains Open Freshwater Depression $(n=49)$ within the Glaciated Northern Grasslands and North Central Brown Glaciated Plains Level IV Ecoregions (Omernik, 1987). The Great Plains Prairie Pothole $(n=19)$, Northwestern Great Plains Riparian $(n=15)$, Western Great Plains Closed Freshwater Depression $(n=13)$, and Great Plains Saline Depression $(\mathrm{n}=8)$ were also well-represented. A number of additional ecological systems were also assessed but were not as common: Emergent Marsh $(\mathrm{n}=5)$, Alpine-Montane Wet Meadow $(\mathrm{n}=6)$, Rocky Mountain Subalpine-Montane Fen ( $\mathrm{n}=1)$, Northern Rocky Mountain Wooded Vernal Pool $(n=1)$, and Intermountain Basins Greasewood Flat $(\mathrm{n}=1)$. A few riparian systems were represented among assessed wetlands, including Lower Montane Riparian Woodland and Shrubland ( $\mathrm{n}=1)$, Rocky Mountain Subalpine-Montane Riparian Shrubland $(\mathrm{n}=2)$, Rocky Mountain Subalpine-Montane Riparian Woodland $(\mathrm{n}=1)$, and the Western Great Plains Floodplain system $(\mathrm{n}=1)$.

\section{Level 2 EIA Condition Scores}

EIA scores for attributes were well distributed for the Landscape Context, Biotic, Hydrologic, and Physicochemical Condition attributes (Appendix $\mathrm{K})$. More sites scored higher for the Landscape Context and Hydrologic Disturbance metrics. The Biotic scores were concentrated in the middle of the range and the Relative Patch Size scores were predominantly high with a small proportion scoring extremely low. Overall condition scores ranged from 50 to 100, with a higher frequency of sites ranking between 80 and 100 (Figure 9).

Overall EIA scores were averaged for each ecological system (Table 7). The following describes the scores for each ecological system (refer to tables in Appendix L and frequency histograms in Appendix M). Only wetlands with assessment data from eight or more sites are discussed. Based on the condition thresholds established in the MTNHP EPA Reference Wetland Project (Newlon 2011) wetlands were grouped into four categories: relatively unaltered $($ scores $=90-100)$, slightly altered $($ scores $=80-89)$, 


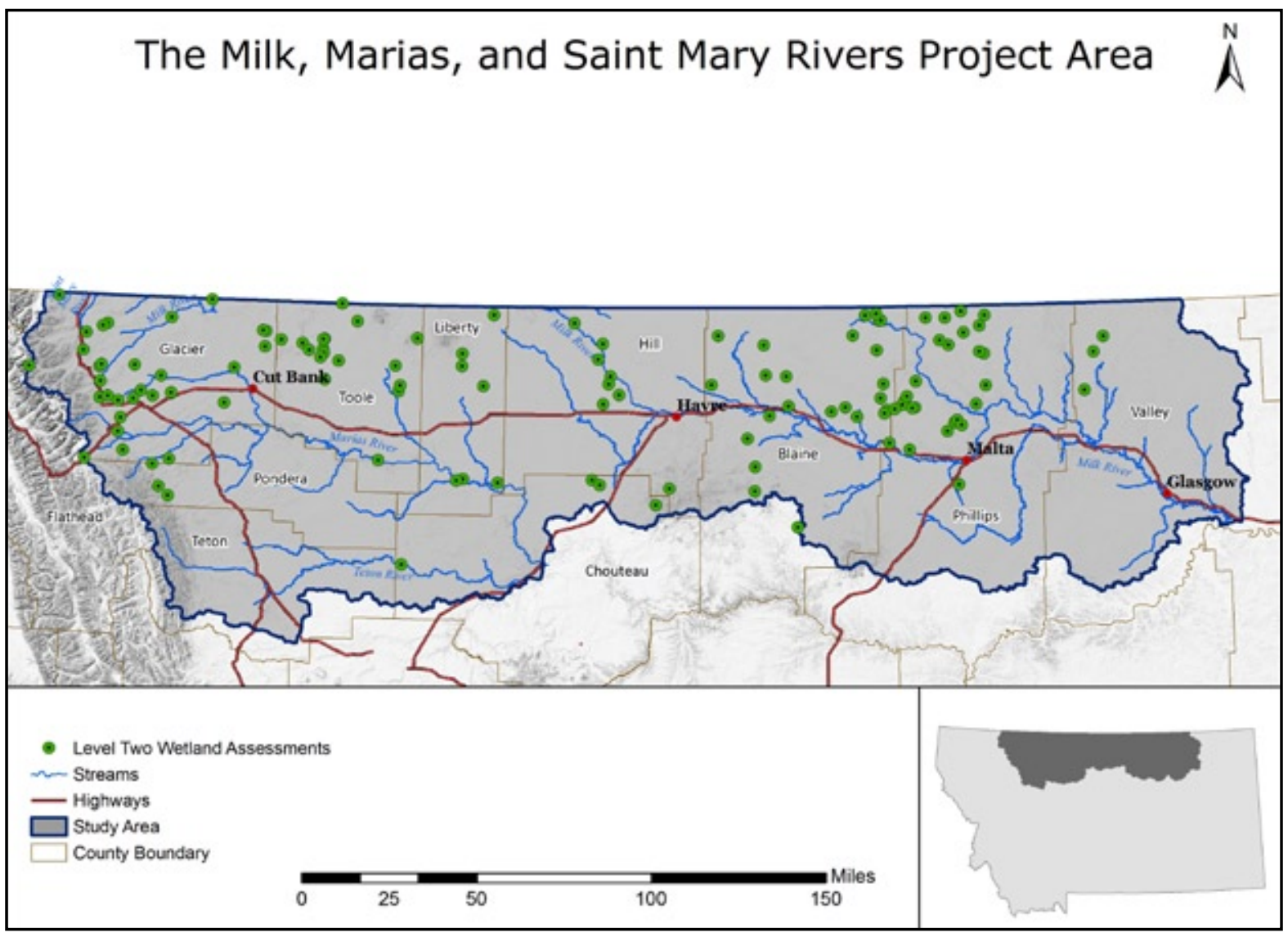

Figure 8. Distribution of Level 2 assessments.

moderately altered (scores $=70-79)$, and severely altered (scores $<70$ ).

\section{Western Great Plains Depressional Wetland Systems}

Great Plains Prairie Potholes scored the highest, followed by Western Great Plains Saline Depressions. Western Great Plains Open and Closed Depressions received lower minimum scores than any other system. Of the Great Plains Prairie Potholes assessed, most of the sites were either relatively unaltered or slightly altered. Three sites were considered moderately altered while three sites were severely altered (Figure 10). Overall condition scores for Western Great Plains Closed Depressions were evenly distributed, with five sites ranked as slightly altered, four sites ranked as moderately altered, and four sites considered severely altered. Thirty-four of the 49 Open Depression wetlands were ranked as moderately to severely altered. Only five Open Depressions were considered to be relatively unal- tered. Seven of the eight Saline Depression sites assessed were ranked as slightly altered to relatively unaltered with only one site considered moderately altered.

\section{Northwestern Great Plains Riparian}

Out of the 15 sites assessed only two wetlands were ranked relatively unaltered and slightly altered. Four sites were ranked moderately altered while the remaining sites are considered severely altered (Figure 10).

\section{Wetland Condition and Water \\ Duration}

Correlation coefficients were compared between each Level 2 attribute score and Cowardin wetland classification water regimes to see if there were any relationships between wetland condition and the duration of standing water (Table 8). The only metric that had a significant correlation to increased water duration was the Biotic attribute, indicating 
Table 6. Number of Level 2 sites by Level IV Ecoregion, 4th code hydrological unit, and hydrogeomorphic type (HGM).

\begin{tabular}{|c|c|c|}
\hline & Level IV Ecoregion & $\mathbf{N}$ \\
\hline $17 \mathrm{r}$ & Scattered Eastern Igneous-Core Mountains & 2 \\
\hline $41 \mathrm{a}$ & Northern Front & 3 \\
\hline $41 b$ & Crestal Alpine-Subalpine Zone & 1 \\
\hline $41 \mathrm{c}$ & Western Canadian Rockies & 1 \\
\hline $41 \mathrm{~d}$ & Southern Carbonate Front & 1 \\
\hline $42 \mathrm{j}$ & Glaciated Northern Grasslands & 40 \\
\hline 421 & Sweetgrass Uplands & 1 \\
\hline $42 \mathrm{~m}$ & Cherry Patch Moraines & 12 \\
\hline $42 n$ & Milk River Pothole Upland & 6 \\
\hline 420 & North Central Brown Glaciated Plains & 32 \\
\hline $42 q$ & Rocky Mountain Front Foothill Potholes & 13 \\
\hline $42 \mathrm{r}$ & Foothill Grassland & 10 \\
\hline \multirow[t]{2}{*}{431} & Missouri Breaks Woodland Scrubland & 1 \\
\hline & HUC 4 & $\mathbf{N}$ \\
\hline Big Sandy Creek & & 1 \\
\hline Milk River & & 78 \\
\hline Missouri-Marias & & 39 \\
\hline Missouri-Musselshell & & 1 \\
\hline Saskatchewan & & 1 \\
\hline St. Mary & & 3 \\
\hline & HGM Type & $\mathbf{N}$ \\
\hline Depressional & & 95 \\
\hline Riverine & & 19 \\
\hline Slope & & 6 \\
\hline Flat & & 1 \\
\hline Lacustrine Fringe & & 2 \\
\hline
\end{tabular}

that wetlands that hold standing water for longer may have fewer non-natives and tolerant native species.

\section{Wetland Condition and Human Disturbance Gradient}

To assess the relationships between the Level 2 attribute scores and the stressors recorded on the stressor checklist in the field, we analyzed correlations between Level 2 attribute scores and the count of different stressor types (Table 9). There were only weak correlations between the two; however, the inverse relationships indicate that the increasing number of stressors may lead to a decline in condition. Buffer and transportation stressors were negatively correlated with the Landscape Context attribute and buffer stressors and hydrology stressors were negatively correlated with the Physicochemical attribute.

\section{Level 3 Analysis Results}

Level 3 vegetation data were collected from 44 sites and then used to assess wetland condition for each site in the study area based on the FQA. Since the majority of the wetlands included in this project were depressional wetlands that undergo cyclic fluctuations in water levels, FQA metrics were calculated and compared separately for wetlands clas- 


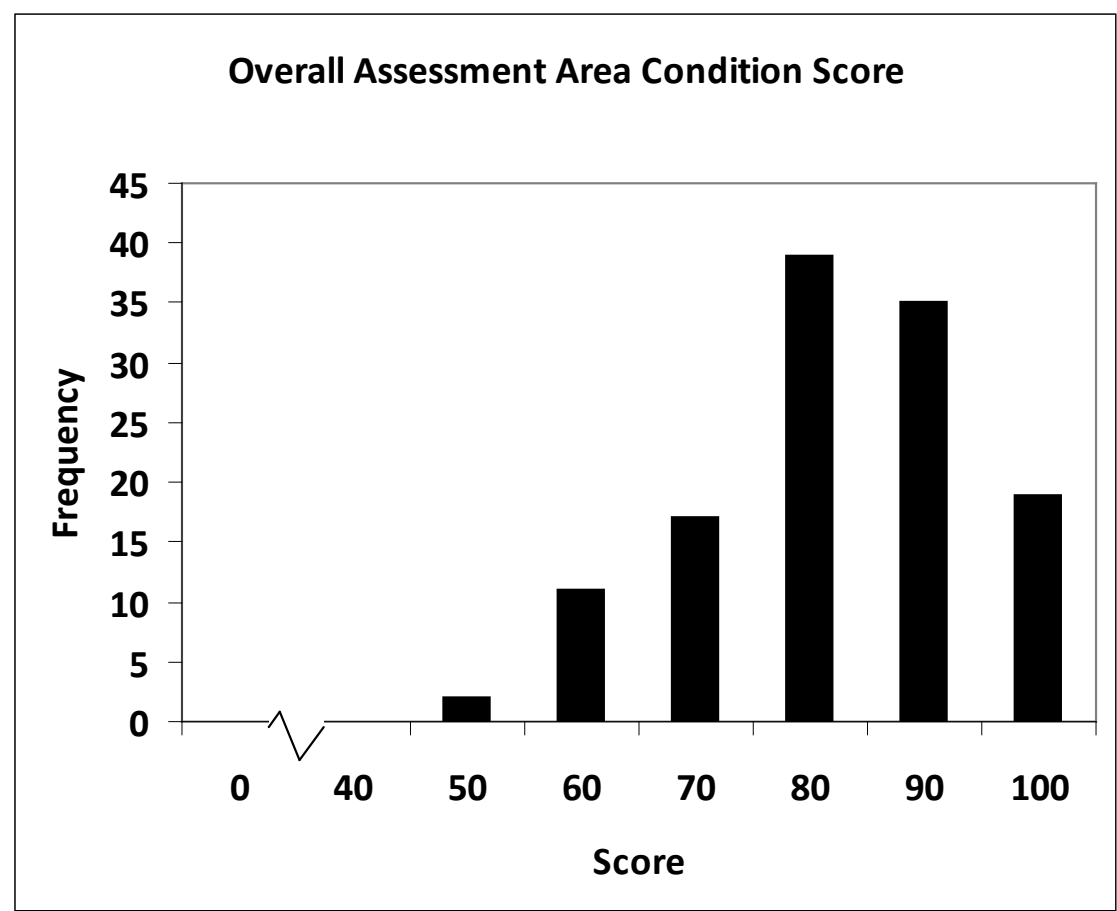

Figure 9. Overall condition scores for Level 2 wetland sites.

Table 7. Mean overall EIA scores with their standard deviations and minimum and maximum scores for each ecological system.

\begin{tabular}{lccccc}
\hline \multicolumn{1}{c}{ Ecological System } & N & Mean & S.D. & Min & Max \\
\hline Great Plains Prairie Pothole & 19 & 83.6 & 11.1 & 57.5 & 98.3 \\
Western Great Plains Closed Depression Wetland & 13 & 73.4 & 13.7 & 42.7 & 87.7 \\
Western Great Plains Open Freshwater Depression Wetland & 49 & 73.4 & 11.7 & 47.7 & 98.3 \\
Western Great Plains Saline Depression Wetland & 8 & 87.3 & 7.9 & 73.7 & 96.7 \\
Northwestern Great Plains Riparian & 15 & 72.2 & 12.1 & 53.2 & 92.2 \\
Western Great Plains Floodplain Systems & 1 & 73.5 & $\sim$ & $\sim$ & $\sim$ \\
Inter-Mountain Basins Greasewood Flat & 1 & 87.5 & $\sim$ & $\sim$ & $\sim$ \\
North American Arid West Emergent Marsh & 5 & 82.1 & 6.5 & 74.9 & 89.8 \\
Rocky Mountain Alpine-Montane Wet Meadow & 6 & 85.5 & 10.2 & 71.6 & 98.3 \\
Northern Rocky Mountain Wooded Vernal Pool & 1 & 53.3 & $\sim$ & $\sim$ & $\sim$ \\
Rocky Mountain Subalpine-Montane Fen & 1 & 69.3 & $\sim$ & $\sim$ & $\sim$ \\
Rocky Mountain Lower Montane Riparian Woodland and & 1 & 86.5 & $\sim$ & $\sim$ & $\sim$ \\
Shrubland & 1 & 79.2 & $\sim$ & $\sim$ & $\sim$ \\
Rocky Mountain Subalpine-Montane Riparian Woodland & 1 & 94.0 & 3.3 & 91.7 & 96.4 \\
Rocky Mountain Subalpine-Montane Riparian Shrubland & 2 &
\end{tabular}




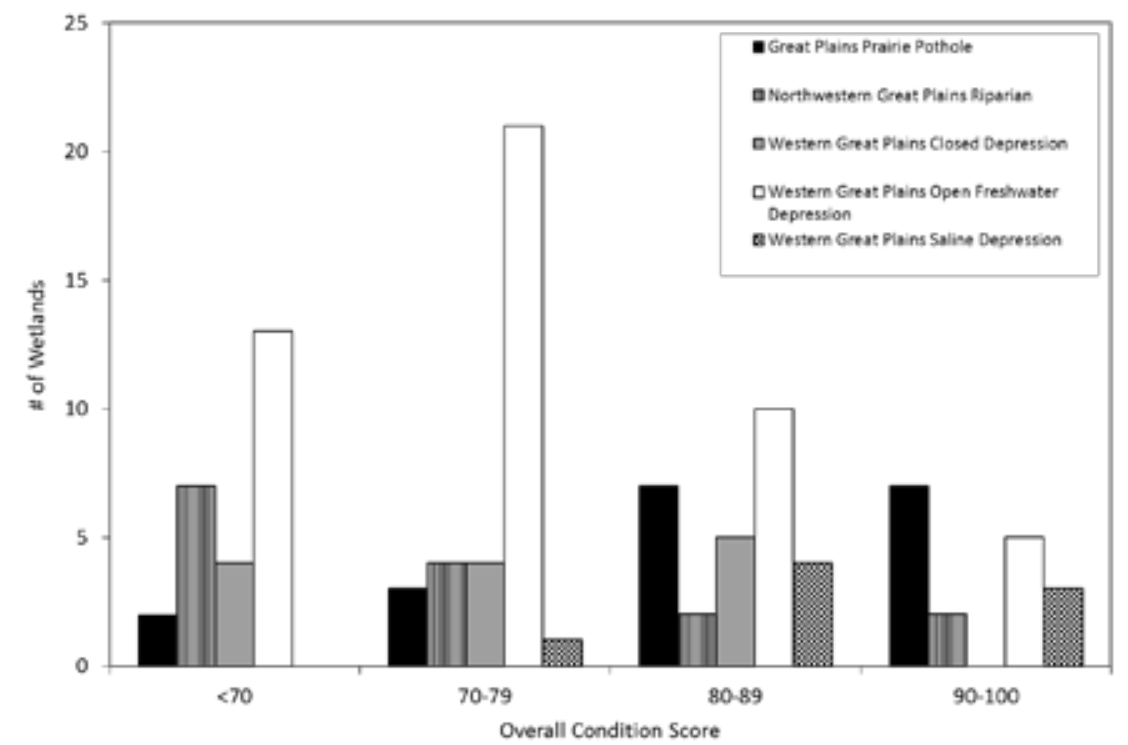

Figure 10. Overall condition scores for the dominant ecological systems within the project area.

Table 8. Correlations between Level 2 attribute scores and Cowardin water regimes using Spearman's correlations. All relationships that are significant at the $=0.05$ level are indicated in boldface.

\begin{tabular}{ll}
\hline & Water Duration \\
\hline Final Land Context & 0.07 \\
Final Relative Patch Size & 0.12 \\
Final Biotic & $\mathbf{0 . 3 2}$ \\
Final Hydrologic & -0.06 \\
Final Physicochemical & 0.10 \\
Final AA Score & 0.16 \\
\hline
\end{tabular}

Table 9. Correlations between Level 2 attribute scores and the number of different stressor types using Spearman's correlations. All relationships that are significant at the $=0.05$ level are indicated in boldface.

\begin{tabular}{lcccccc}
\hline & Buffer & Land Use & \multicolumn{2}{c}{ Transportation } & \multicolumn{2}{c}{ Hydrologic } \\
& Stressors & Stressors & Stressors & Stressors & in the AA Stressors \\
\hline Final Land Context & $\mathbf{- 0 . 2 6}$ & $\mathbf{- 0 . 2}$ & $\mathbf{- 0 . 2 7}$ & -0.13 & 0.06 & $\mathbf{- 0 . 2 2}$ \\
Final Relative Patch Size & 0.01 & 0.15 & -0.01 & -0.04 & -0.06 & -0.01 \\
Final Biotic & -0.16 & -0.02 & -0.04 & $\mathbf{- 0 . 2 1}$ & -0.01 & -0.14 \\
Final Hydrologic & $\mathbf{- 0 . 1 9}$ & -0.05 & -0.06 & $\mathbf{- 0 . 2 3}$ & 0.07 & -0.17 \\
Final Physicochemical & $\mathbf{- 0 . 2 1}$ & -0.16 & 0.07 & $\mathbf{- 0 . 2 5}$ & $\mathbf{- 0 . 2 7}$ & $\mathbf{- 0 . 2 5}$ \\
Final AA Score & $\mathbf{- 0 . 2 5}$ & -0.1 & -0.11 & $\mathbf{- 0 . 2 5}$ & -0.08 & $\mathbf{- 0 . 2 5}$ \\
\hline
\end{tabular}


sified as temporary, seasonal, or semi-permanent (Table 10). However, there was very little variability found between the FQA metrics of wetlands with different water regimes. Species richness and the FQI for total species increased only slightly with increasing water duration. Vegetation metrics for native species had higher values while metrics including exotic species had lower values.

Our Level 3 results indicate that most of the wetlands assessed are dominated by species that can tolerate moderate disturbance as demonstrated by the cover-weighted mean c-values of species found most frequently (Figure 11). In addition, lower adjusted FQI values indicate that most of the assessed sites are dominated by plants that are frequently found in disturbed sites. Only a couple of the sites had a good floristic quality (Figure 12).

\section{Wetland Condition and Human Disturbance Gradient}

Relationships between FQA metrics and the Level 2 stressors checklist recorded on site were analyzed. It was expected that there would be stronger relationships than with the Level 1 landscape met- rics. However, there were no significant correlations between the FQA metrics and the number of stressors. This can be attributed to the assumption that a wetland with more stressors present will be in more impaired condition than a wetland with no or few stressors. In contrast we found that several of the stressors observed independently had large scopes and more severe impacts than the accumulated impacts of many stressors.

The dominant human disturbances observed affecting wetland condition in the project area include roads, conversion of temporary and seasonal wetlands to dryland farming and stockponds, and soil and vegetation disturbance associated with heavy livestock grazing (Figure 13).

Effects of human induced disturbance may covary with natural disturbances. For instance, drought may be affecting wetland condition more than either local or landscape level human disturbances. Effects of drought include reduced zonation and encroachment by terrestrial vegetation in depressional wetland systems. In addition, many wetlands visited were no longer functioning as wetlands but contained relic hydric soils. The regional wetland

Table 10. Mean values for FQA indices by Cowardin water regime with their standard deviations (S.D.).

\begin{tabular}{lcccccc}
\hline & \multicolumn{2}{c}{$\begin{array}{c}\text { Temporary } \\
(\mathbf{n = 1 1})\end{array}$} & \multicolumn{2}{c}{$\begin{array}{c}\text { Seasonal } \\
(\mathbf{n = 1 7})\end{array}$} & \multicolumn{2}{c}{$\begin{array}{c}\text { Semi-permanent } \\
(\mathbf{n = 1 6})\end{array}$} \\
\hline & Mean & S.D. & Mean & S.D. & Mean & S.D. \\
\hline Non-native species richness & 2 & 1 & 3 & 2 & 4 & 2 \\
Native species richness & 6 & 4 & 9 & 5 & 10 & 6 \\
Total species richness & 8 & 5 & 13 & 7 & 14 & 7 \\
\% Native species & 74 & 14 & 76 & 13 & 70 & 14 \\
\% Non-native species & 26 & 14 & 24 & 13 & 30 & 14 \\
Mean C of total species & 4 & 1 & 4 & 1 & 4 & 1 \\
Mean C of native species & 5 & 1 & 5 & 1 & 5 & 0 \\
Cover-weighted mean C for total species & 4 & 1 & 5 & 2 & 4 & 1 \\
Cover-weighted mean C for native species & 5 & 1 & 5 & 1 & 5 & 1 \\
FQI for native species & 10 & 3.2 & 13.5 & 4.6 & 13.6 & 5.6 \\
FQI for total species & 11.8 & 3.7 & 13.9 & 3.9 & 15.0 & 4.1 \\
Cover-weighted FQI for total species & 11.7 & 5.2 & 16.0 & 7.7 & 13.1 & 5.4 \\
Cover-weighted FQI native species & 12.4 & 4.3 & 14.9 & 5.4 & 14.4 & 3.9 \\
Adjusted FQI & 44.4 & 6.1 & 43.3 & 14.2 & 41.2 & 5.4 \\
Adjusted cover-weighted FQI & 46.6 & 7.1 & 46.2 & 15.9 & 40.1 & 8.5 \\
\hline
\end{tabular}




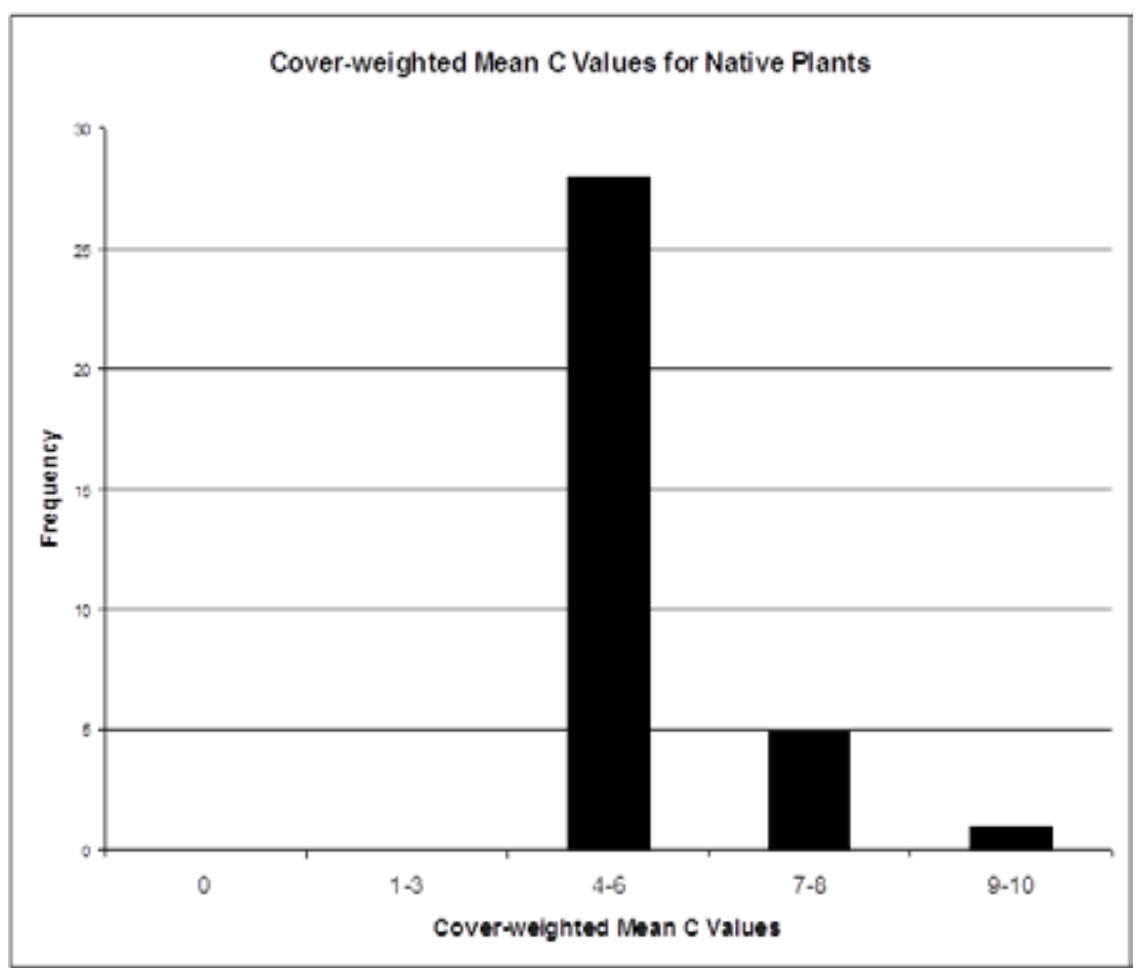

Figure 11. Mean C-Values weighted by the relative average cover of plant species in Level 3 vegetation plots.

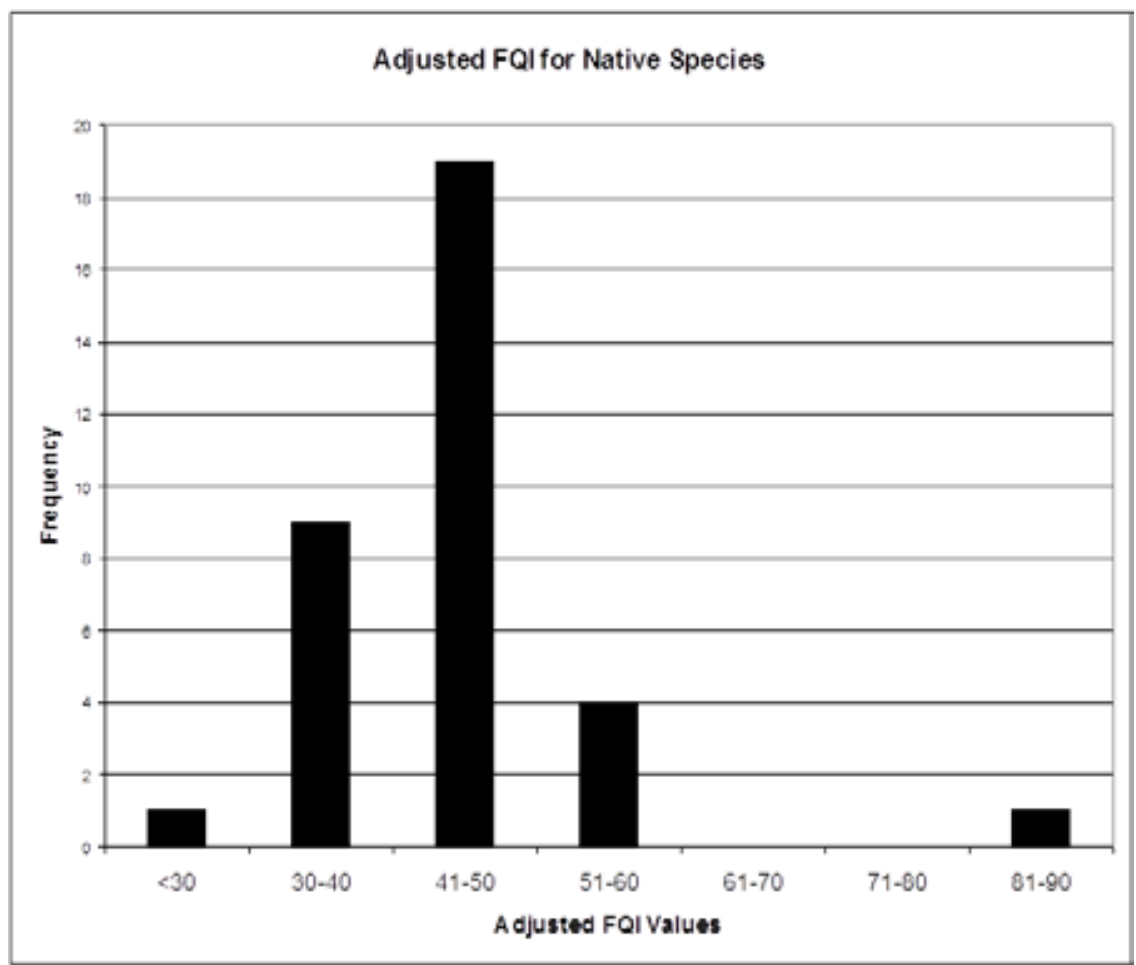

Figure 12. Frequency of adjusted FQI scores. The adjusted FQI incorporates a maximum attainable FQI score based on the highest possible value as well as both native and nonnative species (Miller and Wardrop, 2006). This is a particularly important metric for ecological systems that are naturally species poor like depressional and prairie pothole systems. 

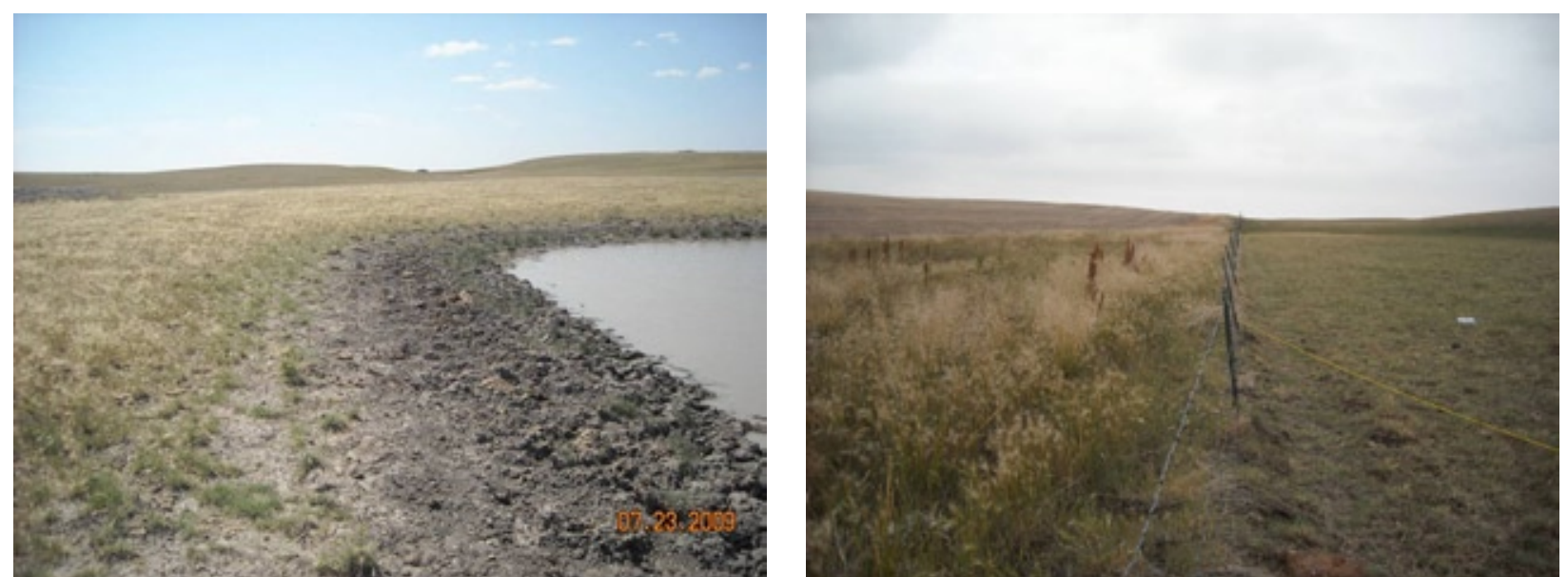

Figure 13. Effects of heavy livestock grazing on wetland soil (left photo) and vegetation (right photo).

indicator status of plant species recorded for the Level 3 assessment indicate that the frequency of facultative upland (FACU) and upland (UPL) species is greater than would be expected in a fully functioning wetland (Figure 14).

To determine the relationship between drought and wetland condition, the relationship between the relative effective annual precipitation (REAP) and
FQA metrics was analyzed (Table 11). Many of the FQA metrics were significantly and positively correlated to REAP. The FQI was strongly positively correlated with REAP, indicating that the floristic quality of wetlands increased in areas with increased precipitation. There were moderate correlations between REAP and total species richness, mean C-values, and the FQI for natives. Both cover-weighted FQI metrics were weakly correlated.

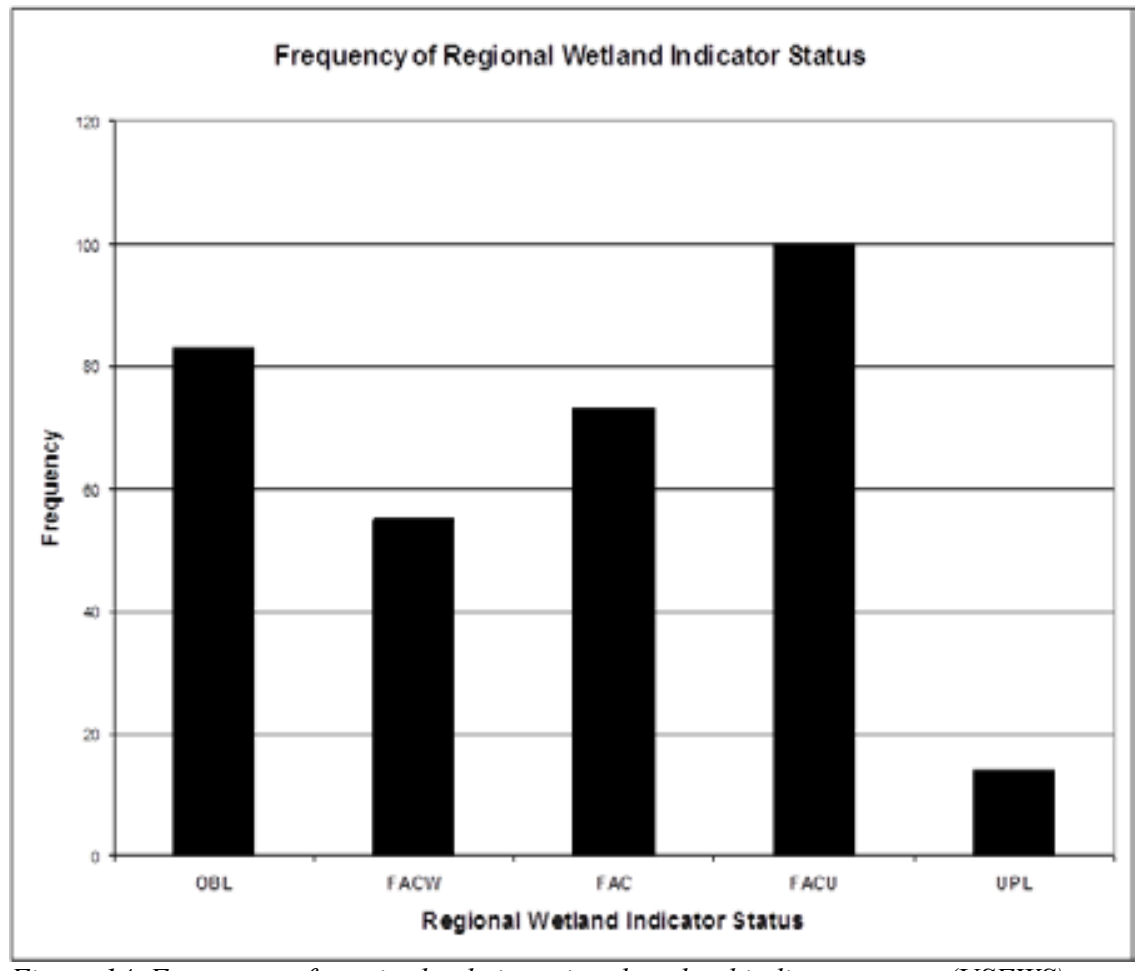

Figure 14. Frequency of species by their regional wetland indicator status (USFWS). 
Table 11. Spearman correlations between Level 3 vegetation data and relative effective annual precipitation (REAP). All relationships that are significant at the $=0.05$ level are indicated in boldface.

\begin{tabular}{l|c}
\hline & REAP \\
\hline NN Richness & 0.19 \\
N Richness & 0.52 \\
Total Richness & 0.48 \\
\% Native & 0.30 \\
\% Non-native & -0.30 \\
Mean C & 0.44 \\
Mean C Nat & -0.22 \\
CW Mean C & 0.01 \\
CW Mean C Nat & -0.10 \\
FQI & 0.60 \\
FQI Nat & 0.45 \\
CW FQI & 0.34 \\
CW FQI Nat & 0.37 \\
Adj FQI & 0.00 \\
Adj CW FQI & 0.01 \\
\hline
\end{tabular}




\section{Discussion}

The goal of this project was to assess wetland condition in the Milk, Marias, and St. Mary watersheds using the EPA's three-tier approach to wetland assessments. An additional goal was to identify potential anthropogenic stressors affecting wetland condition both within the wetland area and in the surrounding landscape at varying spatial scales. Using wetland profiles it was determined that $81 \%$ of the wetlands within the project area are palustrine emergent wetlands with either temporary or seasonal water regimes. There are approximately 101,400 acres of depressional wetlands within the project area. Three watersheds were identified that had a greater number of altered wetlands than unaltered wetlands. This indicates that many of these wetlands are threatened and in need of local level protection.

The Level 1 landscape metric, attribute, and overall scores showed little variability at all three spatial scales. This is due, in part, to the homogeneity of the landscape within the project area. The dominant land uses in this part of Montana are dry land farming and livestock grazing, and much of the area is intersected by local dirt roads. Agricultural land cover within 100 meters of temporary wetlands was determined to influence wetland condition, whereas condition in semi-permanent wetlands is primarily influenced by roads within 100 meters. Because temporary wetlands are usually smaller, more shallow systems that dry out during the growing season, they often encounter more anthropogenic disturbances like tillage for crops within and directly adjacent to the wetland boundary (DeKeyser et al. 2003). With so little variability in the landscape, the landscape level analysis did not provide a reliable assessment of wetland condition.

Results for the Level 2 rapid assessments indicate that among depressional wetlands, Great Plains Prairie Potholes and Great Plains Saline Depressions are in better condition than either Great Plains Open or Closed Depressions. Great Plains Prairie Potholes and Western Great Plains Saline Depressions higher condition scores can be attributed to fewer impacts from livestock grazing. Prairie potholes occur in wetland complexes so that the effects of livestock are more evenly distributed on the landscape and Saline depressions are often dominated by vegetation that is unpalatable. Results for open and closed depression wetlands indicate that these systems are highly susceptible to human disturbances. Northwestern Great Plains Riparian systems had more sites ranked as severely altered, suggesting that these systems need more focused protection. The dominant human disturbances observed and affecting wetland condition include roads, conversion of temporary and seasonal wetlands to dryland farming and stock ponds, and soil and vegetation disturbance associated with heavy livestock grazing.

Level 2 scores were not highly correlated with stressors measured at the site using the stressor checklist. This indicates that either our metrics are not sensitive enough to capture changes in wetland condition from particular stressors or that the stressor checklist is inadequate. Because there were also no significant correlations between the stressors and the Level 3 FQA scores, it is most plausible that the stressor checklist is not a quantitative enough measure of disturbance. Using the tallied number of stressors observed at each site as an indicator of disturbance, it was assumed that the more stressors present at a site the greater the disturbance. What the stressor checklist does not take into account is that many stressors may be present but might only slightly affect wetland condition (e.g. light grazing, light recreation, and horse trail within 500 meters) while one stressor may be present that significantly affects wetland condition (culverts, impoundments, ditches). In the future the scope and severity of each disturbance should also be recorded.

There are several confounding issues with assessing wetlands in this region. Depressional wetlands are dynamic systems where wet-drought cycles influence the ecological communities present (Hansen et al., 1995). Therefore, our assessments are just a snapshot of the ecological condition of the wetland at that stage within its wet-drought cycle. Because assessment results may change depending on the wet-drought cycle it is important to assess 
reference wetlands over a long period of time to establish a gradient of known conditions for wetlands with different water regimes (DeKeyser et al. 2003). There is a significant east to west moisture gradient across the Prairie Pothole region, with decreased precipitation on the western edge due to a rain shadow from the Rocky Mountains. The project area is within the most westerly edge of the Prairie Pothole region and therefore contains wetlands that are much drier and more temporary than wetlands in the eastern part. This east to west gradient increased over the twentieth century, where the western edge of the prairie pothole became significantly drier (Johnson et al. 2010).

Wetlands visited within the project area appeared to be drier than in the past, and in some cases were no longer functioning as wetlands. Many of the depressional wetlands included in the project clearly had historically been functioning temporary or even seasonal wetlands based on relic hydric soils or the presence of a few hydrophytes, but they no longer had the hydrology to sustain plant communities dominated by hydrophytes. These wetlands were dominated by upland species encroaching from the adjacent prairie. In addition, many of the depressional wetlands, while functioning, had reduced zonation, so that only one plant community was present. Wetlands that remain in the drought stage of their wet-drought cycle for long periods of time often end up in an unproductive condition (Johnson et al. 2010). Because plant communities in this region developed in the presence of disturbances like fire and grazing by Bison, in a landscape that lacks these intense, short-duration disturbances, they often become static, which can have a negative affect on wetland condition (DeKeyser et al. 2003). Impacts from drought are not measured in our Level 1 landscape analysis or our Level 2 rapid assessment. Other wetland assessment studies in the Prairie Pothole region have included the low prairie zone surrounding depressional wetlands in vegetation assessments to capture annual shifts of species between the upland and the wetland to account for a fluctuating water regime (DeKeyser et al. 2003). By including the low prairie zone in the future, we can better tease out the influences of adjacent anthropogenic disturbances and shifts in hydrology. In general, however, none of the three levels of assessment may be able to make clear connections between anthropogenic stressors and wetland integrity in this area. Stressors are too evenly distributed, and drought may be an overriding factor driving wetland condition.

The results from this study support the use of a spatially balanced and random survey design.

The condition scores for wetlands in this project were similar to the wetland scores of wetlands surveyed for the MTNHP reference network of wetlands in central and eastern Montana. However, there were more significant correlations between both the Level 1 and Level 2 assessments with the FQA metrics for the reference wetlands. This could be due to the fact that wetlands included in the reference network were targeted and therefore spatially autocorrelated (Moran's I $=0.66$, z-score $=6.03$ ) while sites in this project were not spatially autocorrelated (Moran's I $=0.03$, z-score $=0.05$ ).

Both the Level 1 and Level 2 need further calibration and refinement based on intensive Level 3 assessments. Additional Level 3 assessments should be developed to help in the further validation of our methods. Based on this pilot project, the MTNHP will continue to develop indicators and metrics for a long-term integrated, statewide, multijurisdictional wetland condition monitoring and assessment strategy based on EPA's recommended elements. 


\section{Literature Cited}

Batt, B. D. J., M. G. Anderson, C. D. Anderson, and F. D. Caswell. 1989. The use of prairie potholes by North American ducks. Pages 204-224 in A.G. van der Valk. Northern Prairie Wetlands, Iowa State University Press, Ames, Iowa.

Bourdaghs, M., C. A. Johnston, and R. R. Regal. 2006. Properties and performance of the Floristic Quality Index in Great Lakes coastal wetlands. Wetlands 26: 718-735.

Brinson, M. M. 1993. A hydrogeomorphic classification for wetlands. Technical Report WRPDE-4, Waterways Experiment Station, Army Corps of Engineers, Vicksburg, Mississippi.

Brooks, R. P., D. H. Wardrop, and J. A. Bishop. 2004. Assessing wetland condition on a watershed basis in the mid-Atlantic region using synoptic land-cover maps. Environmental Monitoring and Assessment 94:9-22.

Brooks, R. P., D. H. Wardrop, and C. A. Cole. 2006 . Inventorying and monitoring wetland condition and restoration potential on a watershed basis with examples from Spring Creek watershed, Pennsylvania, USA. Environmental Management 38:673-687.

Collins, J. S., E. Stein, and M. Sutula. 2004. Draft California rapid assessment method for wetlands v. 3.0: User's manual and scoring forms. San Francisco Bay Area Wetlands Regional Monitoring Program web site http://www.wrmp.org/index.html

Cronk, J. K. and M. S. Fennessy. 2001. Wetland Plants: Biology and Ecology. Lewis Publishers, New York, NY.

Dahl, T. E. 1990. Wetland losses in the United States 1780's to 1980's. U.S. Department of Interior, Fish and Wildlife Service, Washington, D.C.
Data Basin. Accessed June 2010. Protected Areas database located at http://www.databasin.org/ protected-center/features/PAD-US-CBI

DeKeyser, E. S., D. R. Kirby, and M. J. Ell. 2003. An index of plant community integrity: development of the methodology for assessing prairie wetland plant communities. Ecological Indicators $3: 119-133$.

ESRI. 2008. ArcGIS 9.2. ESRI Corporation, Redlands, California.

Euliss, N. H., Jr., D. M. Mushet and D. H. Johnson. 2002. Using aquatic invertebrates to delineate seasonal and temporary wetlands in the prairie pothole region of North America. Wetlands 22 (2): 256-262.

Faber-Langendoen, D., G. Kudray, C. Nordman, L. Sneddon, L. Vance, E. Byers, J. Rocchio, S. Gawler, G. Kittel, S. Menard, P. Comer, E. Muldavin, M. Schafale, T. Foti, C. Josse, and J. Christy. 2008 . Ecological Performance Standards for Wetland Mitigation: An Approach Based on Ecological Integrity Assessments. NatureServe, Arlington, VA. + Appendices http:// www.natureserve.org/publications/epaWetlandMitigation.jsp

Faber-Langendoen, D., J. Rocchio, M. Shafale, C. Nordman, M. Pyne, J. Teague, and T. Foti. 2006. Ecological Integrity Assessment and Performance Measures for Wetland Mitigation. NatureServe, Arlington VA.

Hansen, P. L., R. D. Pfister, K. Boggs, B. J. Cook, J. Joy, and D. K. Hinckley. 1995. Classification and Management of Montana's Riparian and Wetland Sites. Montana Forest and Conservation Experiment Station, School of Forestry, The University of Montana, Missoula, MT. Miscellaneous Publication No.54. 
Hargiss, C. L. M., E. S. DeKeyser, D. R. Kirby, and M. J. Ell. 2008. Regional assessment of wetland plant communities using the index of plant community integrity. Ecological Indicators 8:303-307.

Hychka, K. C., D. H. Wardrop, and R. P. Brooks. 2007. Enhancing a landscape assessment with intensive data: a case study in the upper Juniata watershed. Wetlands 27:446-461.

Johnson, B. 2005. Hydrogeomorphic wetland profiling: an approach to landscape and cumulative impacts analysis. EPA/620/R05/001. U.S. Environmental Protection Agency, Washington, D.C.

Johnson, W. Carter, B. Werner, G. R. Guntenspergen, R. A. Voldseth, B. Millett, D.E. Naugle, M. Tulbure, R. W. H. Carroll, J. Tracy, and C. Olawsky. 2010. Prairie wetland complexes as landscape functional units in a changing climate. Bioscience 60: 128-140.

Jones, W. M. 2003. Milk and lower Marias River watersheds: assessing and maintaining the health of wetland communities. Report to the Montana Department of Environmental Quality and the U.S. Environmental Protection Agency. Montana Natural Heritage Program, Helena, MT. 17 pp. plus appendices.

Jones, W. M. 2004. Using vegetation to assess wetland condition: a multimetric approach for temporarily and seasonally flooded depressional wetlands and herbaceous-dominated intermittent and ephemeral riverine wetlands in the northwestern glaciated plains ecoregion, Montana. Report to the Montana Department of Environmental Quality and the U.S. Environmental Protection Agency. Montana Natural Heritage Program, Helena, MT. 34 pp. plus appendices.

Karr, J. R., and D. R. Dudley. 1981. Ecological perspective on water quality goals. Environmental Management 5:55-68.

Karr, J. R., and E. W. Chu. 1999. Restoring life in running waters: Better biological monitoring. Island Press. Washington, D.C.
Kentula, M. E. 2007. Foreword: monitoring wetlands at the watershed scale. Wetlands 27: 412415 .

Leibowitz, S. G. and K. C. Vining. 2003. Temporal connectivity in a prairie pothole complex. Wetlands 23:13-25.

Lopez R. D., and M. S. Fennessy. 2002. Testing the floristic quality assessment index as an indicator of wetland condition. Ecological Applications 12:487-497.

McNab, W. H., and P. E. Avers, eds. 1994. Ecological subregions of the United States: section descriptions. U.S. Department of Agriculture, Forest Service. Publication WO-WSA-5, Washington, D.C.

Milburn, S. A., M. Bourdaghs, and J. J. Husveth. 2007. Floristic Quality Assessment for Minnesota Wetlands. Minnesota Pollution Control Agency, St. Paul, Minnesota.

Miller, L. M. and D. H. Wardrop. 2006. Adapting the floristic quality assessment index to indicate anthropogenic disturbance in central Pennsylvania wetlands. Ecological Indicators 6: 313-326.

Mitsch, W. J. and J. G. Gosselink. 2000. Wetlands, Third Edition. John Wiley \& Sons, New York, NY.

Montana Department of Administration and Information Technology Services Division. 1999. The Montana Cadastral Database. http://gis.mt.gov.

Munsell Color Company. 2000. Munsell Soil Color Charts (rev. ed.). Munsell Color Company, Gretag Macbeth, New Windsor, NY.

National Research Council. 2001. Compensating for wetland losses under the Clean Water Act. Committee on Mitigating Wetland Losses, Board on Environmental Studies and Toxicology, National Academy Press, Washington, D.C. 
Nesser, J. A., G. L. Ford, M. C. Lee, and D. S. Page-Dumroese. 1997. Ecological units of the Northern Region: subsections. General Technical Report INT-GTR-369, U.S. Department of Agriculture, Forest Service, Intermountain Research Station, Ogden, Utah.

Newlon, K. R. and L. K. Vance. 2011. A reference wetland network for assessment and monitoring of Montana's herbaceous wetlands. Report to the United States Environmental Protection Agency. Montana Natural Heritage Program, Helena, MT. 23pp. plus appendices.

Northern Great Plains Floristic Quality Assessment Panel. 2001. Floristic quality assessment for plant communities of North Dakota, South Dakota (excluding the Black Hills), and adjacent grasslands. Jamestown, ND. Northern Prairie Wildlife Research Center.

Omernik, J. M. 1987. Ecoregions of the conterminous United States. Map (scale 1:7,500,00). Annals of the Association of American Geographers 77:118-125.

Peet, R. K., T. R. Wentworth, and P. S. White. 1998. A flexible, multipurpose method for recording vegetation composition and structure. Castanea 63: 262-274.

R Development Core Team. 2009. R: A language and environment for statistical computing. $\mathrm{R}$ Foundation for Statistical Computing, Vienna, Austria. ISBN 3-900051-07-0, URL http://www. R-project.org.

Rocchio, J. 2006a. Rocky Mountain subalpinemontane riparian shrubland ecological system: Ecological Integrity Assessment. Unpublished report prepared for the Colorado Department of Natural Resources and US EPA Region 8 by the Colorado Natural Heritage Program, Colorado State University, Fort Collins, Colorado.
Rocchio, J. 2006b. Ecological integrity assessments for North American Arid Freshwater Marsh, Rocky Mountain Montane-Alpine Wet Meadows, Rocky Mountain Upper MontaneSubalpine Fens, Rocky Mountain Upper Montane-Subalpine Riparian Shrublands, Rocky Mountain Upper Montane-Subalpine Riparian Woodlands, Rocky Mountain Lower Montane Riparian Woodland and Shrubland, and Intermoutain Basin Playas. Unpublished report prepared for NatureServe, Arlington, VA. Reports available online at: http://www.cnhp.colostate. edu/reports.html or http://www.NatureServe.org/ getData/eia_integrity_reports.jsp

Shjeflo, J. B. 1968. Evapotranspiration and the water budget of prairie potholes in North Dakota. U.S. Geological Survey Professional Paper 585B, 49 p.

Stein, E. D., A. E. Fetscher, R. P. Clark, A. Wiskind, L. Grenier, M. Sutula, J. N. Collins, and C. Grosso. 2009. Validation of a wetland rapid assessment methods: use of EPA's Level 1-2-3 framework for method testing and refinement. Wetlands 29: 648-665.

Stevens, D. L., Jr. 1997. Variable density gridbased sampling designs for continuous spatial populations. Environmetrics, 8:167-95.

Stevens, D. L., Jr. and A. R. Olsen. 1999. Spatially restricted surveys over time for aquatic resources. Journal of Agricultural, Biological, and Environmental Statistics 4:415-428.

Stevens, D. L., Jr. and A. R. Olsen. 2004. Spatiallybalanced sampling of natural resources in the presence of frame imperfections. Journal of American Statistical Association 99:262-278.

Stevens, D. L., Jr. and S. F. Jensen. 2007. Sample design, execution, and analysis for wetland assessment. Wetlands 27:515-523. 
Stewart, R. E., and H. A. Kantrud. 1971. Classification of natural ponds and lakes in the glaciated prairie region. Publ. 92, U.S. Dept. of the Interior Fish and Wildlife Service, Washington, DC. $57 \mathrm{pp}$.

USDA Natural Resource Conservation Service. 2006. Field indicators of hydric soils in United States, version 6.0. ed. G. W. Hurt and L. M. Vasila, Fort Worth, TX: USDA NRCS in cooperation with the National Technical Committee for Hydric Soils. (http://soils.usda.gov/use/hydric/).

Van der Kamp, G., W. J. Stolte, and R. G. Clark. 1999. Drying out of small prairie wetlands after conversion of their catchments from cultivation to permanent brome grass. Hydrological Sciences 44: 387-397.

Van Sickle, J. and R. M. Hughes. 2000. Classification strengths of ecoregions, catchments, and geographic clusters for aquatic vertebrates in Oregon. Journal of the North American Benthological Society 19: 370-384.

Vance, L. K. 2009. Assessing wetland condition with GIS: a landscape integrity model for Montana. A report to the Montana Department of Environmental Quality and the Environmental Protection Agency. Montana Natural Heritage Program, Helena, MT. 23 pp. plus appendices.

Wardrop, D. H., M. E. Kentula, D. L. Stevens, Jr., S. F. Jensen, and R. P. Brooks. 2007. Assessment of wetland condition: an example from the Upper Juniata watershed in Pennsylvania, USA. Wetlands 27:416-431.

Western Regional Climate Center. 2010. Western U.S. climate historical summaries. (http://www. wrcc.dri.edu/Climsum.html). Desert Research Institute, Reno, Nevada. Accessed June 2010.

White, D. and S. Fennessy. 2005. Modeling the suitability of wetland restoration potential at the watershed scale. Ecological Engineering 24:359-377.
Winter, T. C. 1989. Hydrologic studies of wetlands in the Northern Prairie. Pages 16-54 in A. G. van der Valk, editor. Northern Prairie Wetlands. Iowa State University Press, Ames, Iowa.

Winter, T. C. and D. O. Rosenberry. 1995. The interaction of groundwater with prairie potholes in the Cottonwood Lake area, east-central North Dakota, 1979-1990. Journal of Hydrology 15: 193-221.

Winter, T. C. and D. O. Rosenberry. 1998. Hydrology of prairie pothole wetlands during drought and deluge: A 17-year study of the Cottonwood Lake wetland complex in North Dakota in the perspective of longer term measured and proxy hydrologic records. Climate Change 40: 189-209. 

Appendix A. Ecological System Descriptions 



\section{Western Great Plains Closed Depressional Wetland}

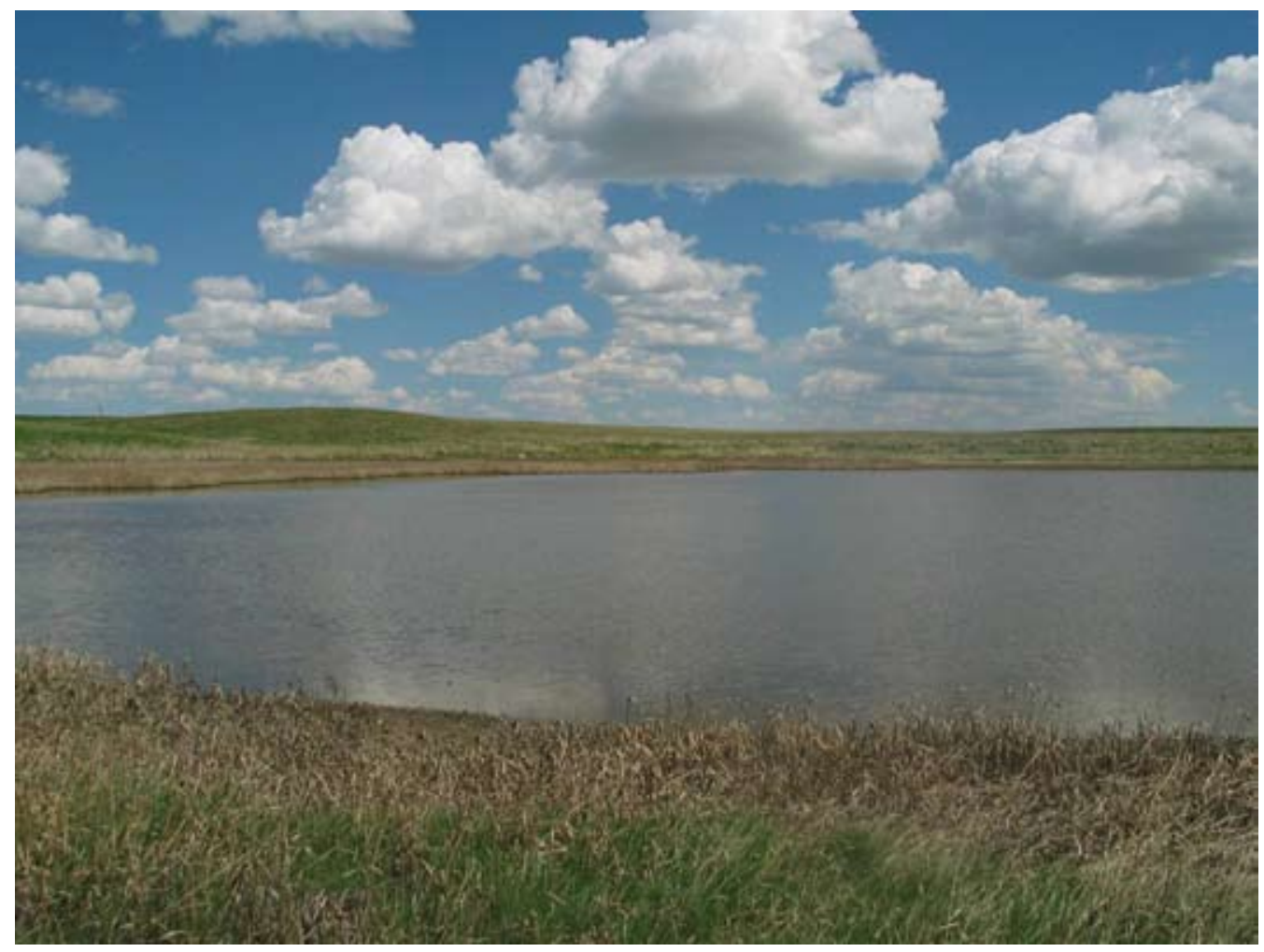

\section{General Description}

This system includes a variety of depressional wetlands generally found in complexes in central and eastern Montana. This type of wetland differs from Western Great Plains Open Depressional Wetlands and Great Plains Prairie Potholes by being completely isolated from both the regional groundwater system and inter-wetland surface drainage systems. They occur in depressional basins found in flat, enclosed upland areas or on level shallow lake basins. The major sources of input water are precipitation and snow melt, and water loss occurs through evapotranspiration. The basins are typified by the presence of an impermeable layer, such as dense clay formed in alluvium that is poorly drained. Subsurface soil layers are restrictive to water movement and root penetration. Ponds and lakes associated with this system can experience periodic drawdowns during dry years, but are replenished by spring rains. Closed depressions experience irregular hydroperiods, most filling with water only occasionally and drying quickly, influencing the plant communities that are present. The drawdown zone is typically dominated by western wheatgrass (Pascopyrum smithii) and foxtail barley (Hordeum jubatum). Povertyweed (Iva axillaris) and willow dock (Rumex salicifolius) occupy the broad, low gradient basins which are shallowly inundated in the spring and draw down every year to reveal bottoms of gray bentonite. Common spikerush (Eleocharis palustris) occurs within the drawdown area where there is more organic matter in the substrate. Hardstem bulrush (Schoenoplectus acutus) typifies closed depressions sufficiently deep to remain permanently inundated during most years. Species richness can vary considerably among individual examples of this system and it is especially influenced by adjacent land use like agriculture and grazing. 


\section{Diagnostic Characteristics}

lowland, herbaceous, depression, depressional, playa, clay subsoil, impermeable layer, saturated, isolated wetland, strictly isolated wetland

\section{Range}

This system can be found throughout the eastern portion of the Western Great Plains; however, it is most prevalent in the central states of Nebraska, Kansas and Oklahoma. In Montana, closed depressions are most concentrated to the north of the HiLine and Route 2, from the Blackfeet Reservation to the North Dakota border. Individual depressions can also be found across the Northwest Glaciated Plains north of the Missouri River.

\section{Environment}

This system is typified by depressional basins found in flat enclosed upland areas and level shallow lake basins, with an impermeable layer such as dense clay isolating the wetland from the regional groundwater system. It differs from Western Great Plains Open Depression Wetlands and Great Plains Prairie Potholes by being completely isolated from both the regional groundwater system and inter-wetland surface drainage systems. These wetlands occur in depressional basins found in flat enclosed upland areas or on level shallow lake basins. The major sources of input water are precipitation and snow melt; water loss occurs through evapotranspiration. The basins are typified by the presence of an impermeable layer, such as dense clay formed in alluvium that is poorly drained. Subsurface soil layers are restrictive to water movement and root penetration (Cook and Hauer, 2007). Ponds and lakes associated with this system can experience periodic drawdowns during dry years, but are replenished by spring rains. Closed depressions experience irregular hydroperiods, filling with water only occasionally and drying quickly, which influences the plant communities that are present.

\section{Vegetation}

Vegetation within this system is highly influenced by hydrology, salinity, fire and adjacent land uses. The drawdown zone is typically dominated by western wheatgrass (Pascopyrum smithii) and foxtail barley (Hordeum jubatum), the most common wet meadow component of this landscape. Needle spikerush (Eleocharis acicularis) and the small annual forbs slender plantain (Plantago elongata) and purslane speedwell (Veronica peregrina) are common in most stands. Povertyweed (Iva axillaris) and willow dock (Rumex salicifolius) occupy the broad, low gradient basins which are shallowly inundated in the spring and draw down every year to reveal bottoms of gray bentonite. The common spikerush (Eleocharis palustris) association is also within the drawdown zone but occurs at sites where there is more organic matter in the substrate. Foxtail barley (Hordeum jubatum) and needle spikerush (Eleocharis acicularis) are typically well represented in drier stands, while water knotweed (Polygonum amphibium) stands are found at wetter sites. Marsh vegetation, dominated by hardstem bulrush (Schoenoplectus acutus), typifies depressions sufficiently deep to remain permanently inundated during most years. Forbs commonly associated with these marsh communities include water knotweed (Polygonum amphibium), common spikerush (Eleocharis palustris) and two headed water-starwort (Callitriche heterophylla). 


\section{Dynamic Processes}

These systems developed under Northern Great Plains climatic conditions, which included natural disturbances by large herbivores, periodic flooding events and occasional fire. Wet-drought year climatic cycles in Montana, often in 10 to 20 year intervals, influence the ecological communities in these systems (Hansen et al. 1995). Each year seeds from annuals and perennials germinate and cover exposed mud flats, but when precipitation floods the depressions, the annuals drown and the perennials survive. Over a series of years the perennials dominate. The drawdown to mudflats is necessary so that emergent vegetation can become reestablished. This flooding, drawdown and the eventual exposure of mud flats drive the water-level vegetation cycle.

\section{Management}

Changes will occur in the plant communities due to climatic conditions and/or management actions. Due to the nature of the soils, these sites are considered moderately resilient. With continued adverse impacts, a moderate decline in vegetative vigor and composition will occur. Heavy continuous grazing and/or continuous seasonal (spring) grazing, without adequate recovery periods will eventually lead to loss of the Western wheatgrass-foxtail barley wetland community, and inland saltgrass will begin to increase. Western wheatgrass will increase initially, but then will begin to decrease. In time, heavy continuous grazing will cause inland saltgrass, fowl bluegrass (Poa palustris), and other pioneer perennials and annuals to increase. This replacement plant community is resistant to change, due to the grazing tolerance of inland saltgrass and increased surface salts. However, a significant amount of production and diversity has been lost compared to the Western wheatgrass -foxtail barley community, and the loss of key cool season grasses and increased bare ground will affect energy flow and nutrient cycling. Water infiltration will be reduced significantly due to the massive shallow root system "root pan" characteristic of inland saltgrass, and the increased amount of bare ground. It will take a long time to bring this plant community back with management alone (USDA NRCS, 2003).

\section{Restoration Considerations}

The major barriers to restoration are isolation, infrequent flooding, impermeable soils and invasive species. These factors must be addressed during the planning and long term management of restored wetlands.

\section{Original Concept Authors}

Natureserve Western Ecology Group

\section{Montana Version Authors}

C. McIntyre, L. Vance, T. Luna

\section{Version Date}

$2 / 9 / 2010$

\section{Citation:}

Great Plains Closed Depressional Wetland - Western Great Plains Closed Depressional Wetland. Montana Field Guide. Retrieved on July 5, 2010, from http://FieldGuide.mt.gov/displayES_Detail.aspx?ES=9252 


\section{Western Great Plains Open Freshwater Depression Wetland}

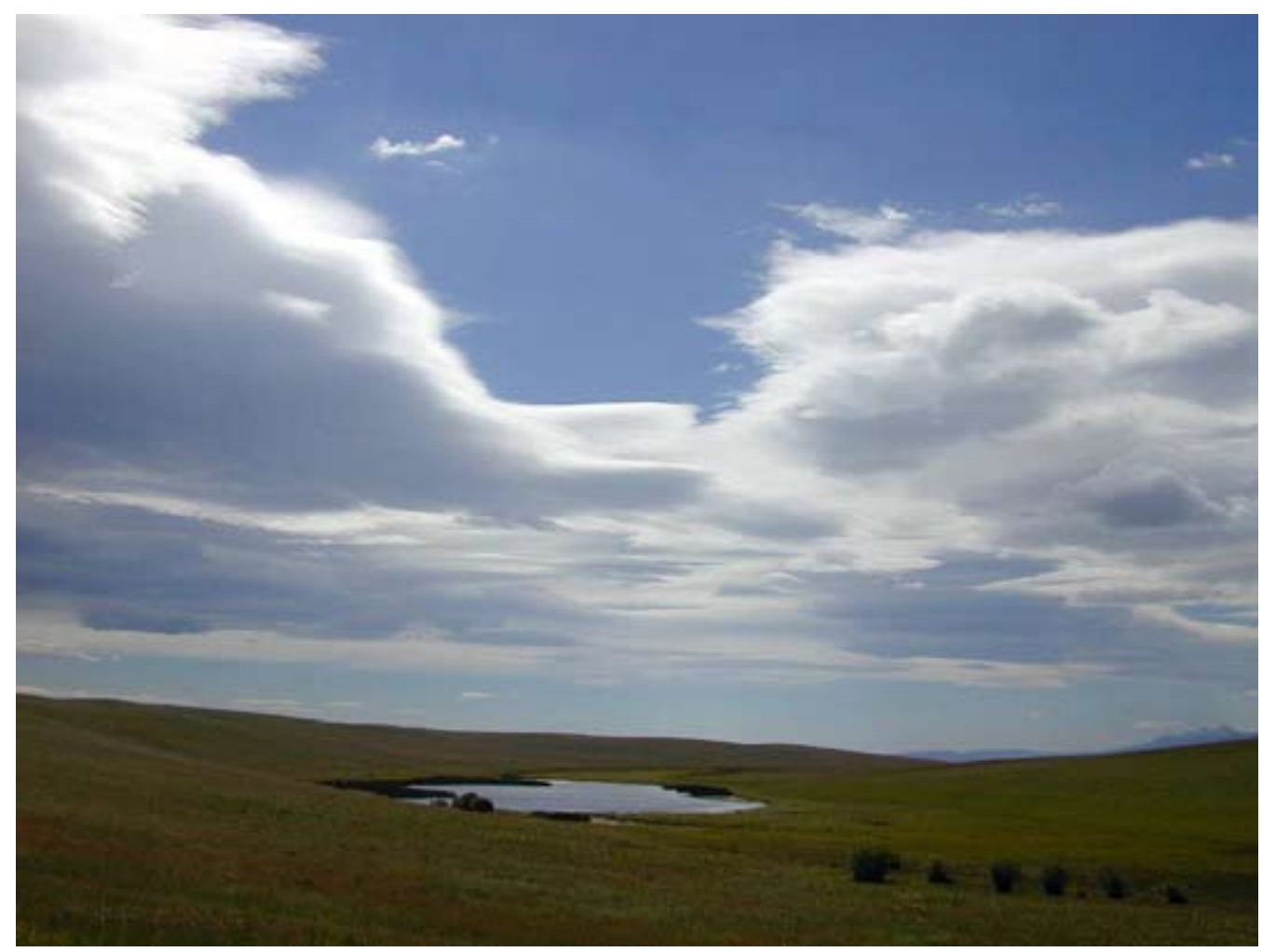

\section{General Description}

This Great Plains system occurs in lowland depressions and along lake borders with open basins and a permanent water source through most of the year. This system is distinguished from the Western Great Plains Closed Depression Wetlands by having a larger watershed and/or significant connection to the groundwater table. Soils are typically Mollisols, Entisols or occasionally Histosols. Soil pH varies from neutral to slightly alkaline. In Montana, this system is especially well represented along major and secondary tributaries of the Milk, Marias and Two Medicine rivers in the northwestern Great Plains glaciated pothole region. Throughout Montana, most sites within this system are found at elevations of 664-2,027 meters (2,180-6,650 feet). Species diversity can be high in some occurrences. These wetlands usually contain emergent graminoids such as cattails (Typha species), sedges (Carex species), spikerushes (Eleocharis species), rushes (Juncus species) and bulrushes (Schoenoplectus species), as well as floating vegetation such as pondweeds (Potamogeton species), arrowhead (Sagittaria species), or common hornwort (Ceratophyllum demersum). At montane elevations, these systems can be moderately complex with a variety of species and communities. Increased grazing pressure in and adjacent to these systems will change the plant communities that are present. In semi-permanent systems, the drawdown zone is typically dominated by beaked sedge (Carex utriculata) water sedge (Carex aquatilis), and Nebraska sedge (Carex nebrascensis). In seasonal ponds that draw down annually, and in semipermanent wetlands during drought years, buried seeds of both annuals and perennials will germinate in exposed mud flats. 


\section{Diagnostic Characteristics}

Herbaceous, depression, depressional, saturated soils, partially isolated

\section{Range}

This system occurs across the western Great Plains from North Dakota and Kansas west to Montana and south to Texas. This system can occur throughout the western Great Plains but is likely more prevalent in the south-central portions of the division. Its distribution extends into central Montana, where it occurs in the matrix of the Northwestern Great Plains Mixed Grass Prairie. However, these depressions are most concentrated to the north of the Hi-Line and Route 2, from the Blackfeet Reservation to the North Dakota border. Individual depressions can also be found across the Northwest Glaciated Plains north of the Missouri River.

\section{Environment}

Open depression wetlands are found throughout the Northwestern Glaciated Great Plains region of Montana. They form in lowlands, and along lake borders and stream margins. They generally have more open basins, a large watershed, and a permanent water source throughout most of the year, except during exceptional drought years. This system differs from closed depressional wetlands by having a larger watershed and/or significant connection to the groundwater table (Cook and Hauer 2007). In Montana, most sites within this system are found at elevations of 664-2,027 meters (2,180-6,650 feet). Soils are typically Mollisols, Entisols or occasionally Histosols. Soil $\mathrm{pH}$ varies from neutral to slightly alkaline.

\section{Vegetation}

Open depression wetlands often have submerged aquatic plants in the open water zone including common hornwort (Ceratophyllum demersum), short spikewater milfoil (Myriophyllum sibiricum), and horned pondweed (Zannichellia palustris) as well as floating-leaved plants including pondweeds (Stuckenia and Potamogeton species), white water crowfoot (Ranunculus aquatilis) and arrowheads (Sagittaria species). The central marsh zone is typically dominated by hardstem bulrush (Schoenoplectus acutus), but softstem bulrush (Schoenoplectus tabernaemontani), common threesquare (Schoenoplectus pungens) and alkali bulrush (Schoenoplectus maritimus), often co-dominate. Also found in the marsh zone are cattails (Typha species), water knotweed (Polygonum amphibium), and hemlock water parsnip (Sium suave). The seasonally flooded zones are typically dominated by graminoids including common spikerush (Eleocharis palustris), needle spikerush (Eleocharis acicularis), American sloughgrass (Beckmannia syzigachne), wheat sedge (Carex atherodes), foxtail barley (Hordeum jubatum), shortawn foxtail (Alopecurus aequalis), and water foxtail (Alopecurus geniculatus). Open depressional systems are often bordered by wet prairie zones characterized by species such as slimstem reedgrass (Calamagrostis stricta), clustered field sedge (Carex praegracilis), bluejoint (Calamagrostis canadensis) and fowl bluegrass (Poa palustris). Open depressions with more alkaline or saline water and soil chemistry will typically be bordered by species such as saltgrass (Distichlis spicata), western wheatgrass (Pascopyrum smithii), and freshwater cordgrass (Spartina pectinata). Sites that have been moderately grazed often have an increase in Baltic rush (Juncus balticus), knotted rush (Juncus nodosus), foxtail barley (Hordeum jubatum), American sloughgrass (Beckmannia syzigachne), and western wheatgrass (Pascopyrum smithii). 


\section{Dynamic Processes}

These systems developed under Northern Great Plains climatic conditions, and experienced the natural influence of large herbivores, periodic flooding events and occasional fire. Wet-drought year climatic cycles in Montana, often in 10 to 20 year intervals, influence the ecological communities (Hansen et al., 1995). Seeds from annuals and perennials germinate and cover exposed mud flats, but when precipitation floods the depressions, the annuals drown and the perennials survive. Over a series of years the perennials dominate. The drawdown to mudflats is necessary so that emergent vegetation can become reestablished. Flooding, drawdown and the eventual exposure of mud flats drive the water-level vegetation cycle. Species richness can vary considerably among individual examples and is especially influenced by adjacent land use. Agriculture may provide nutrient and herbicide runoff. In saline soil wetlands, the increase in precipitation during exceptionally wet years can dilute the salt concentration in the soils, which may allow for less salt-tolerant species to occur.

\section{Management}

Changes will occur in the plant communities due to climatic conditions and/or management activities. Conversion to agriculture and pastureland can impact this system when it alters the hydrology of the system.

\section{Restoration Considerations}

In open depression wetland systems where water has been drained or diverted, the original hydrology of the system must be restored. If water levels are restored, re-growth and re-colonization from dormant rhizomatous root systems of common emergent species can occur within a few years. Livestock grazing should be controlled to allow regrowth, recolonization and resprouting from existing root systems. Many of the characteristic species found in these systems are rhizomatous, and exhibit excellent erosion control properties. In some cases, if hydric soils are heavily altered due to pugging or compaction, addition of organic material may be needed to facilitate vegetation recolonization.

\section{Original Concept Authors}

Natureserve Western Ecology Group

\section{Montana Version Authors}

L. Vance, C. McIntyre, T. Luna

\section{Version Date}

$2 / 9 / 2010$

\section{Citation:}

Great Plains Open Freshwater Depression Wetland - Western Great Plains Open Freshwater Depression Wetland. Montana Field Guide. Retrieved on July 5, 2010, from http://FieldGuide. mt.gov/displayES_Detail.aspx?ES=9218 


\section{Great Plains Prairie Pothole}

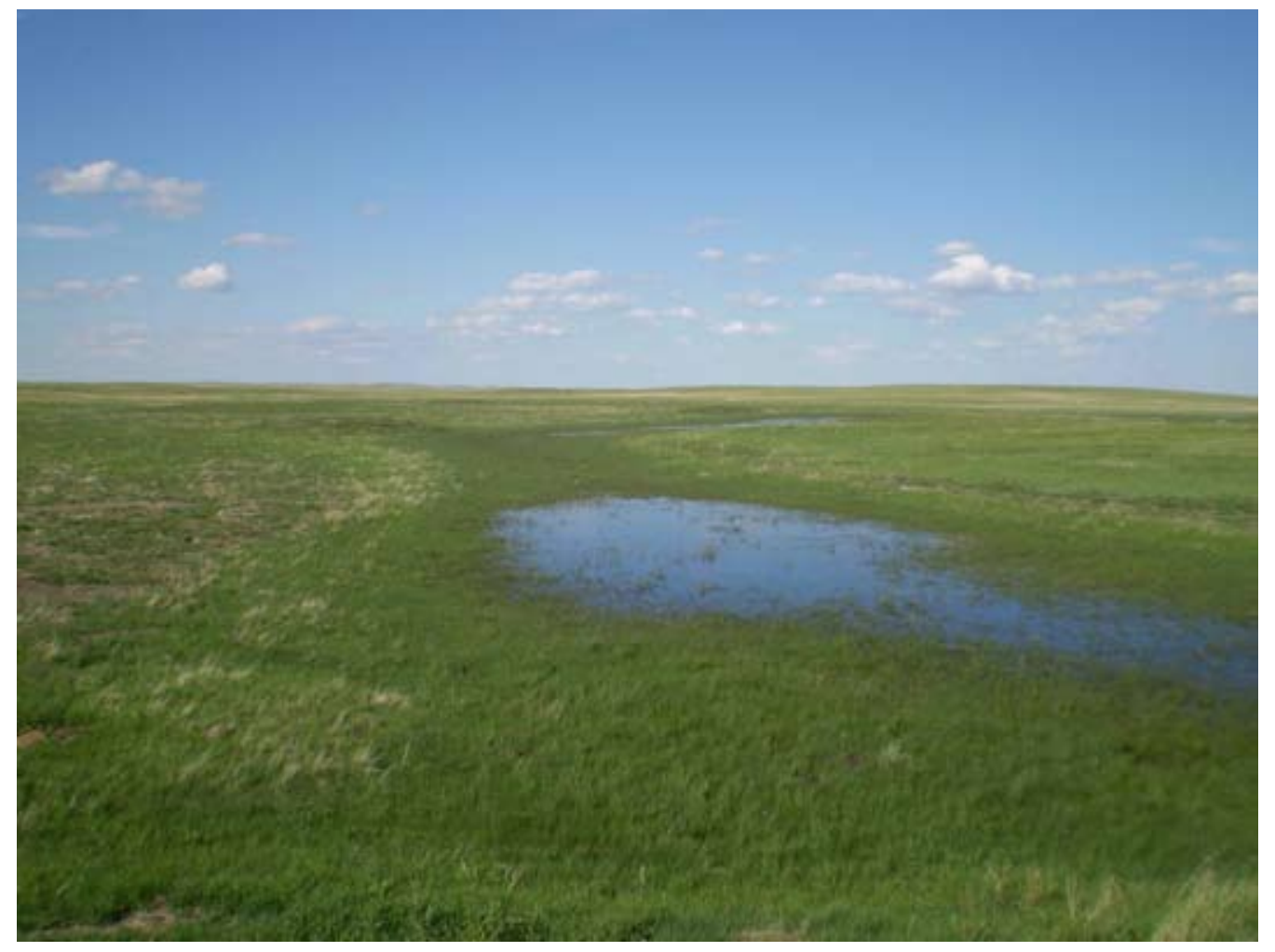

\section{General Description}

Prairie potholes occur in shallow depressions scraped out by glaciers in the northern Great Plains of Montana. The region is characterized by a glacial landscape of end moraines, stagnation moraines, outwash plains and lake plains. The glacial drift forms steep to slight local relief with fine-grained, silty to clayey soils. Limestone, sandstone, and shales are the predominant parent materials, and highly mineralized water can discharge from these rocks. The hydrology of this system is complex, and the concentration of dissolved solids results in water that ranges from fresh to extremely saline, with chemical characteristics varying seasonally and annually. Most prairie potholes and associated lakes contain alkaline water, which accumulates rapidly in during spring months, especially when soil frost is sufficiently deep to forestall all infiltration until after the ground thaws. Most water loss occurs through evapotranspiration, which exceeds precipitation during summer months. Vegetation within this system is highly influenced by hydrology, salinity and dynamics. Potholes can vary in depth and duration, which determines the local gradient of plant species. Similarly, species found within individual potholes will be strongly influenced by periodic drought and wet periods. The wettest sites, where water stands through summer, are characterized by hardstem bulrush (Schoenoplectus acutus), often occurring as a near monoculture, or with softstem bulrush (Schoenoplectus tabernaemontani) or common threesquare (Schoenoplectus pungens) along slightly drier margins. In permanently flooded sites, aquatic buttercups (Ranunculus species), aquatic smartweeds (Polygonum species), pondweeds (Potamogeton species) or duckweeds (Lemna species) are common. At the drier extremes, pothole vegetation generally occurs in a concentric pattern from a wetter middle dominated by 
spikerush (Eleocharis species) through a drier ring of foxtail barley (Hordeum jubatum) and an outer margin of western wheatgrass (Pascopyrum smithii) or thickspike wheatgrass (Elymus lanceolatus). Prairie potholes are considered to be the most important breeding habitat for waterfowl in North America, with production estimates ranging from 50\% to 80\% of the continent's main species. However, the extreme variability in climate and pothole water levels also results in extreme fluctuations in waterfowl populations from year to year. Prairie pothole wetlands also support a diverse assemblage of water-dependent birds.

\section{Diagnostic Characteristics}

lowland, herbaceous depressional, pothole, isolated wetland, temperate

\section{Range}

In Montana, most prairie potholes are concentrated north of the HiLine and Route 2, from the Blackfeet Reservation to the North Dakota border, although individual potholes occur across the Northwest Glaciated Plains north of the Missouri River. Elsewhere, this system occurs throughout the northern Great Plains from central Iowa northeast to southern Saskatchewan and Alberta. It encompasses approximately 870,000 square kilometers with approximately $80 \%$ of its range in southern Canada. It is also prevalent in North Dakota, South Dakota, and northern Minnesota.

\section{Environment}

The prairie pothole ecological system is dominated by closed basins that receive irregular inputs of water from the surroundings and export water as groundwater. The climate is characterized by mid-continental temperature and precipitation extremes. The region is distinguished by a thin mantle of glacial drift with overlying stratified sedimentary rocks of the Mesozoic and Cenozoic ages; these form a glacial landscape of end moraines, stagnation moraines, outwash plains and lake plains. The glacial drift is from 30 meters to 120 meters thick and forms steep to slight local relief with fine-grained, silty to clayey soils. Limestone, sandstone, and shales are predominant, and highly mineralized water can discharge from these rocks. Precipitation and runoff from snowmelt are often the principal water sources, with groundwater inflow as a secondary source. Evapotranspiration is the primary source of water loss, with seepage loss secondary. The hydrology of this system is complex, and the concentration of dissolved solids results in water that ranges from fresh to extremely saline, with chemical characteristics varying seasonally and annually. Most prairie potholes and associated lakes contain water that is alkaline $(\mathrm{pH}>7.4)$. Surrounding uplands are generally in cropland (small grains), hay, or range.

Prairie potholes are considered to be the most important breeding habitat for waterfowl in North America, with production estimates ranging from $50 \%$ to $80 \%$ of the continent's main species. However, the extreme variability in climate and pothole water levels also results in extreme fluctuations in waterfowl populations from year to year. Prairie wetlands also support a diverse assemblage of water-dependent birds including Montana species of concern such as the Blackcrowned Night-Heron (Nycticorax nycticorax), White-faced Ibis (Plegadis chihi), Franklin's Gull (Larus pipixcan), Common Tern (Sterna hirundo), Forster's Tern (Sterna forsteri), and Black Tern (Chlidonias niger). American White Pelicans (Pelecanus erythrorhynchos) feed extensively on tiger salamanders (Ambystoma tigrinum) found in prairie potholes. Sparsely-vegetated alkali potholes, especially in Sheridan County, are attractive to Piping Plovers (Charadrius melodus). 


\section{Vegetation}

Vegetation within this system is highly influenced by hydrology, salinity and dynamics. This system includes elements of emergent marshes and wet, sedge meadows that develop into a pattern of concentric rings. Potholes can vary in depth and duration, which determines the local gradient of species. Similarly, plant species found within individual potholes will be strongly influenced by periodic drought and wet periods. The wettest sites, where water stands into or through summer, are characterized by hardstem bulrush (Schoenoplectus acutus), often occurring as a near monoculture, or with a fringe of softstem bulrush (Schoenoplectus tabernaemontani) or common threesquare (Schoenoplectus pungens) along slightly drier margins. Cattails (Typha spp.) are also seen in these wetter systems, although they are typically a minor component. During spring or in permanently flooded sites, aquatic buttercups (Ranunculus species), aquatic smartweeds (Polygonum species), pondweeds (Potamogeton species) or duckweeds (Lemna species) may be abundant. At the drier extremes, pothole vegetation generally occurs in a concentric pattern from a wetter middle dominated by spikerush (Eleocharis species) through a drier ring of foxtail barley (Hordeum jubatum) and an outer margin of western wheatgrass (Pascopyrum smithii) or thickspike wheatgrass (Elymus lanceolatus) (Hansen et al. 1996, Lesica 1989). Grazing, draining, and mowing of this system can influence vegetation distribution.

\section{Dynamic Processes}

Flooding is the primary natural dynamic influencing this system. Snowmelt in the spring often floods this system and can cause the prominent potholes within the system to overflow. Greater than normal precipitation can flood out emergent vegetation and/or increase herbivory by animal species such as muskrats. Periodic wet and droughty periods cause shifts in vegetation. Vegetation zones are evident, and each zone responds to changing environmental conditions. Draining and conversion to agriculture can also significantly impact this system. Much of the original extent of this system has been converted to cropland, and many remaining examples are under pressure to be drained.

\section{Management}

Livestock use of potholes is limited by low palatability of characteristic species, although open water attracts livestock for both drinking and cooling. When upland vegetation becomes sparse, cattle will graze on spikerush and bulrush. Wet soils are easily trampled. Grazing, when properly planned and executed, can be a management tool, preventing cattail encroachment into open water, limiting the spread of exotics such as crested wheat (Agropyron cristatum) and smooth brome (Bromus inermis), and avoiding excessive litter buildup. Prescribed burning can be used to the same ends. Prairie potholes are primarily threatened by crop agriculture, by unrestricted grazing, and by oil and gas development. Region-wide, nearly half of this system has been lost.

\section{Restoration Considerations}

In Great Plains prairie pothole wetland systems where water has been drained or altered, the original hydrology of the system must be restored. If water levels are restored, re-growth and re-colonization from dormant rhizomatous root systems of common emergent species can occur within a few years. Many of the characteristic species found in marsh systems are rhizomatous, thus exhibit excellent erosion control properties. However, species that are infrequent in these wetland systems may not re-occur or re-establish in a given time frame. The major barriers to 
prairie pothole restoration are isolation, infrequent flooding and invasive species. These factors must be addressed during the planning and long term management of restored prairie pothole wetlands.

During restoration, cattle grazing needs to eliminated or controlled to allow regrowth, recolonization and resprouting from existing root systems. In some cases, if hydric soils are heavily altered due to pugging or compaction, addition of organic material may be needed to facilitate plant recolonization.

\section{Original Concept Authors}

Natureserve Western Ecology Group

\section{Montana Version Authors}

L.K. Vance, C. McIntyre, T. Luna

\section{Version Date}

$2 / 9 / 2010$

\section{Citation:}

Great Plains Prairie Pothole — Great Plains Prairie Pothole. Montana Field Guide. Retrieved on July 5, 2010, from http://FieldGuide.mt.gov/displayES Detail.aspx?ES=9203 


\section{Great Plains Saline Depression Wetland}

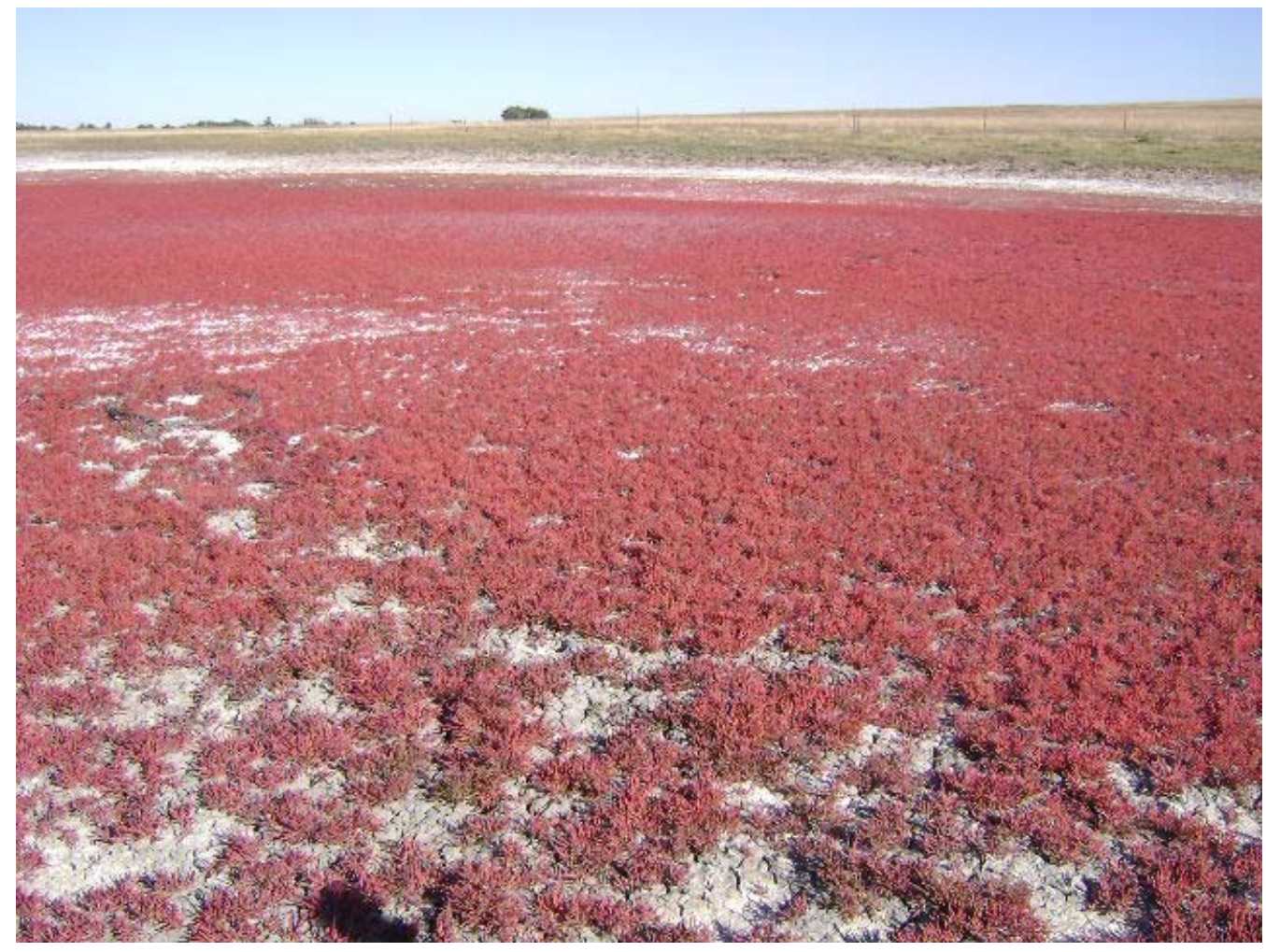

\section{General Description}

This ecological system is very similar to both the Western Great Plains Open Freshwater Depression Wetland and the Western Great Plains Closed Depression Wetland found in wetland complexes in the central and northeastern portion of Montana. However, this system differs due to increased soil salinity, which causes these systems to become brackish. This high salinity is attributed to high evaporation and the accumulation of minerals dissolved in the water. Wetlands in this system are discharge wetlands, where water high in dissolved salts has moved from the regional groundwater system into the depression. Hydroperiods vary depending on precipitation and snowmelt, the primary source of water. Water is prevented from percolating out of the depression due to impermeable dense clay, and salt encrustations can occur on the surface with drying. Species that typify this system are salt-tolerant and halophytic graminoids such as alkali bulrush (Schoenoplectus maritimus), common three square (Schoenoplectus pungens), inland saltgrass (Distichlis spicata), Nuttall's alkali grass (Puccinellia nuttalliana), foxtail barley (Hordeum jubatum), red swampfire (Salicornia rubra) and freshwater cordgrass (Spartina pectinata), and shrubs such as black greasewood (Sarcobatus vermiculatus). During exceptionally wet years, an increase in precipitation can dilute the salt concentration in the soils in some cases, allowing for less salt-tolerant species to occur. The distribution of this system extends into central Montana, where it occurs in the matrix of the Northwestern Great Plains Mixed Grass Prairie. However, these depressions are most concentrated to the north of the HiLine and Route 2, from the Blackfeet Reservation to the North Dakota Border. Individual occurrences can also be found across the Northwest Glaciated Plains north of the Missouri River. 


\section{Diagnostic Characteristics}

Isolated to partially isolated wetland, depression, saline conditions

\section{Range}

This system can occur throughout the western Great Plains but is more prevalent in the southcentral portions of the division. Its distribution extends into central Montana where it occurs in the matrix of the Northwestern Great Plains Mixed Grass Prairie. These saline depressions are most concentrated to the north of the HiLine and Route 2, from the Blackfeet Reservation to the North Dakota Border. Individual depressions can also be found across the Northwestern Glaciated Plains north of the Missouri River.

\section{Environment}

This system is distinguished from the freshwater depression systems by brackish water caused by strongly saline and alkaline soils. This high salinity is attributed to excessive evaporation and the accumulation of minerals dissolved in groundwater discharge. Water is prevented from percolating out of the depression due to an impermeable dense clay soil. Salt encrustations can occur on the surface due to slow water movement (Hansen et al, 1996). On the Blackfeet Indian reservation, water samples collected from saline depressions had conductivity values that ranged from 1,550-40,000 uhmos/cm (Lesica and Shelley, 1988).

\section{Vegetation}

Vegetation within this system is highly influenced by soil salinity and soil moisture. Salt-tolerant and halophytic species that typify this system include alkali bulrush (Schoenoplectus maritimus), common three square (Schoenoplectus pungens), inland saltgrass (Distichlis spicata), Nuttall's alkali grass (Puccinellia nuttalliana), foxtail barley (Hordeum jubatum), red swampfire (Salicornia rubra) and freshwater cordgrass (Spartina pectinata), and shrubs such as black greasewood (Sarcobatus vermiculatus). Other species include western wheatgrass (Pascopyrum smithii) and foxtail barley (Hordeum jubatum). Plant zonation related to soil salinity is often apparent in these systems with distinct rings occurring around the fringe of the depression. In deeper, more depressed halophytic habitats, red swampfire or prairie cordgrass will dominate with Nuttall's alkali grass found directly upslope, followed by inland saltgrass. Shrubs such as greasewood and winterfat (Krascheninnikovia lanata) are common around the outer margins of this system. Pursh seepweed (Suaeda calceoliformis), annual goosefoot (Chenopodium species) and seaside arrowgrass (Triglochin maritima) are common forbs.

In northeastern Montana, the alkali bulrush association occurs as an emergent band around open water or as zonal vegetation around other plant associations. Water tables are often high, often remaining above the soil surface at least through late summer. Soils are poorly drained, alkaline Entisols. Alkali bulrush forms dense, monotypic stands with up to $91 \%$ cover. In some areas along the wetland edge, very minor amounts of common spikerush (Eleocharis palustris) may be present. Alkali bulrush can survive periods of total inundation up to 1 meter (3.3 feet) deep, as well as drought periods where the water table remains less than 1 meter below the soil surface. It is a vigorously rhizomatous species that colonizes and spreads when the water table is within 10 centimeters ( 4 inches) of the surface. Cover of alkali bulrush may be replaced by red swampfire and other associated species during drought years. 
Red swampfire occurs in the drawdown zone that is flooded during the early part of the growing season but where the water table drops below soil surface by late spring or early summer. Soils in this zone usually have silty-clay to clay texture, and the soil surface is covered with salt crusts. Principle salts are sulfates and chlorides of sodium and magnesium. It is one of a very few species that can persist in these hyper-saline conditions when the water table drops below the soil surface (Dodd and Coupland 1966).

\section{Dynamic Processes}

These systems developed under Northern Great Plains climatic conditions that include natural influence of periodic flooding events and occasional fire. Climate has an important effect on saline areas because precipitation and snowmelt transport salts to the depressions and can dilute the soil solution while temperature and wind influence the rate of evapotranspiration. Increased precipitation and/or runoff can dilute the salt concentration and allow for less salt-tolerant species to occur while increased evapotranspiration increases soil salinity leading to a more brackish habitat type.

\section{Management}

Changes will occur in the plant communities due to climatic conditions and/or management activities.

\section{Restoration Considerations}

In saline depression wetland systems where water has been drained or altered, the original hydrology of the system must be restored. If hydrology is restored, re-growth and re-colonization from dormant rhizomatous root systems of common emergent species can occur during periods of flooding. Cattle grazing should be deferred or controlled to allow regrowth, recolonization and resprouting from existing root systems. Annuals such as red swampfire and annual goosefoots require periods of inundation and drawdown to initiate germination and to complete their life cycles at the end of the growing season.

\section{Original Concept Authors}

Natureserve Western Ecology Group

\section{Montana Version Authors}

T. Luna, C. McIntyre, L.K. Vance

\section{Version Date}

$2 / 9 / 2010$

\section{Citation:}

Great Plains Saline Depression Wetland - Western Great Plains Saline Depression Wetland. Montana Field Guide. Retrieved on July 5, 2010, from http://FieldGuide.mt.gov/displayES Detail. aspx?ES=9256 


\section{Western North American Emergent Marsh}

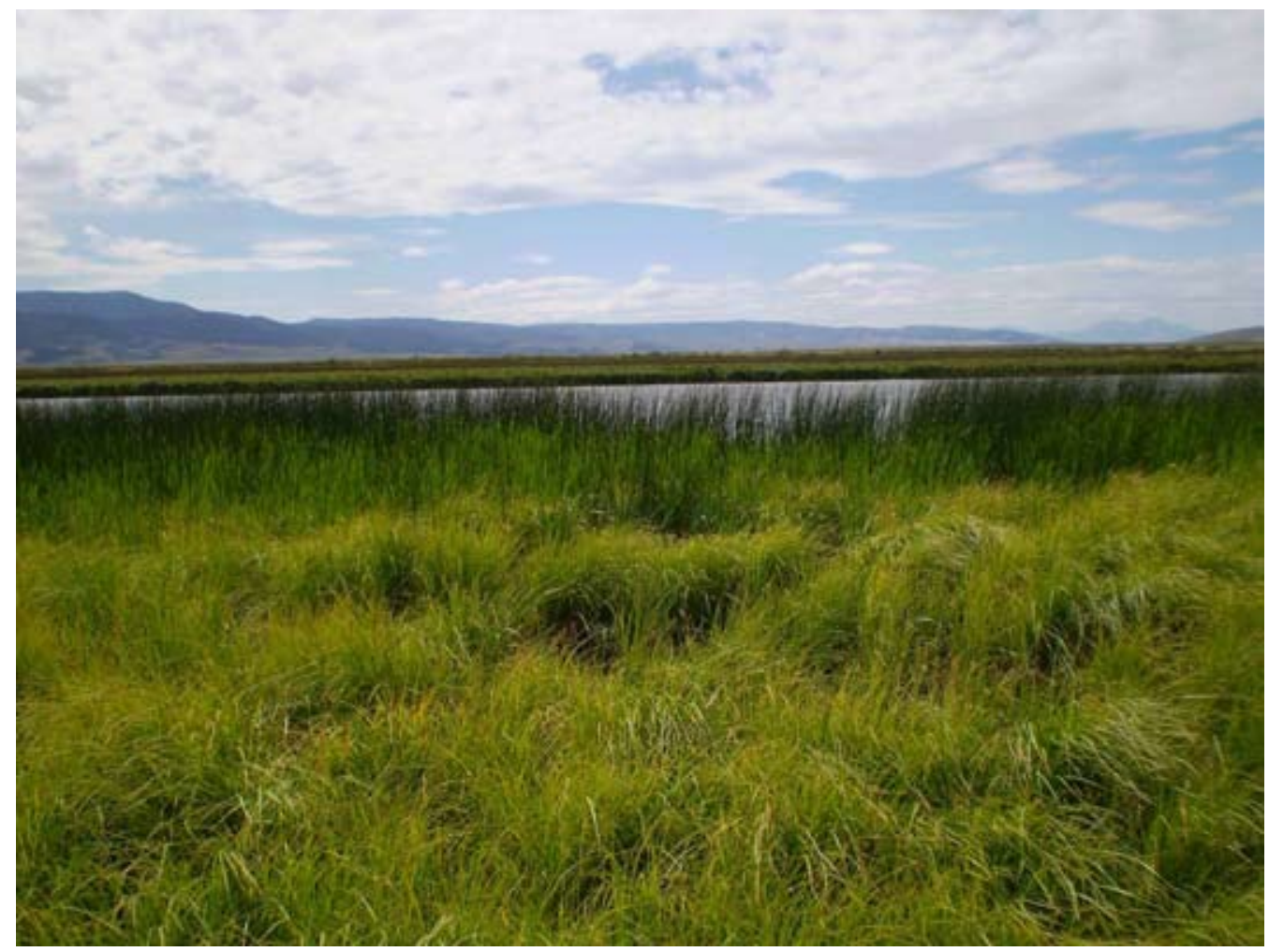

\section{General Description}

This widespread wetland system occurs throughout the arid and semi-arid regions of North America. In Montana, this system is typically found in depressions surrounded by an upland matrix of mixed prairie, shrub steppe, or steppe vegetation. Natural marshes occur in and adjacent to ponds and prairie potholes, as fringes around lakes or oxbows, and along slow-flowing streams and rivers as riparian marshes. Marshes are classified as either seasonal or semipermanent based on the dominant vegetation found in the deepest portion of the wetland; vegetation is representative of the hydroperiod. A central shallow marsh zone dominated by graminoids and sedges characterizes seasonal wetlands, while semipermanent wetlands are continually inundated, with water depths up to 2 meters (6.5 feet) and a deeper central marsh zone dominated by cattails (Typha species) and bulrushes (Schoenoplectus species). Water chemistry may be alkaline or semi-alkaline, but the alkalinity is highly variable even within the same complex of wetlands. Marshes have distinctive soils that are typically mineral, but can also accumulate organic material. Soils characteristics reflect long periods of anaerobic conditions. Dominant vegetation often includes western wheatgrass (Pascopyrum smithii), Northwest Territory sedge (Carex utriculata), Nebraska sedge (Carex nebrascensis), broadleaf cattail (Typha latifolia), and hardstem bulrush (Schoenoplectus acutus). Alkaline marsh communities include western wheatgrass, fresh water cordgrass (Spartina pectinata), and seashore saltgrass (Distichlis spicata). 


\section{Diagnostic Characteristics}

Herbaceous, depressional, mineral with A horizon greater than $10 \mathrm{~cm}$, aquatic herb, deep water greater than $15 \mathrm{~cm}$, saturated soil

\section{Range}

This wetland ecological system occurs throughout western North America. In Montana, it is system is found throughout the state at foothill to upper montane elevations.

\section{Environment}

This system is found in environments where precipitation is approximately 25 to 50 centimeters (10 to 20 inches) per year. In Montana, this system is typically found in depressions surrounded by an upland matrix of mixed prairie, shrub steppe, steppe vegetation and forests near the mountains. Natural marshes occur in and adjacent to ponds and prairie potholes, as fringes around lakes or oxbows, and along slow-flowing streams and rivers as riparian marshes. Water chemistry may be alkaline or semi-alkaline, but is highly variable even within the same complex of wetlands. Marshes have distinctive soils that are typically mineral, but can also accumulate organic material. Soils characteristics reflect long periods of anaerobic conditions, with gleying, high organic content, and redoximorphic features. Wetland marshes are classified as either seasonal or semi-permanent based on the dominant vegetation found in the deepest portion of the wetland (Stewart and Kantrud 1971 and LaBaugh et al. 1996). Vegetation communities occurring in these marsh systems is representative of their hydroperiod; some basins dry to bare soil after seasonal flooding, while others will have a variety of wetland types in a zoned pattern dependent on seasonal water table depths and salt concentrations (Kudray and Cooper 2006).

\section{Vegetation}

Vegetation communities change according to wet-drought cycles. In seasonal ponds that dry out annually, and in semipermanent wetlands during drought years, buried seeds of both annuals and perennials germinate, covering exposed mud flats (Hansen et al. 1995). In semi-permanent marshes, the drawdown zone is typically dominated by western wheat grass (Pascopyrum smithii) near the upland edge, with Northwest Territory sedge (Carex utriculata) and Nebraska sedge (Carex nebrascensis) as the dominant sedges located down gradient, and broadleaf cattail (Typha latifolia) and hardstem bulrush (Schoenoplectus acutus) located in the deeper, central portion of the marsh. Water sedge (Carex aquatilis) is frequently co-dominant with Northwest Territory sedge. Less commonly, blister sedge (Carex vesicaria) and awned sedge (Carex atherodes) are intermixed with Northwest Territory sedge or occur as co-dominants on similar sites. Beyond the emergent vegetation, floating-leaved hydrophytes may be present in wetter sites with longer inundation periods, including water lilies (Nymphaea species), yellow pondlily (Nuphar species), buttercup (Ranunculus species) and pondweed (Potamogeton species). Other floating species may be present in shallow water, such as duckweed, (Lemna species), and submergents such as common hornwort (Ceratophyllum demersum), horned pondweed (Zannichellia palustris), mare's tail (Hippuris vulgaris) and water milfoil (Myriophyllum species).

Seasonal marshes are typically dominated by western wheat grass (Pascopyrum smithii), beaked sedge (Carex utriculata), inflated sedge (Carex vesicaria), Nebraska sedge (Carex nebrascensis), creeping spikerush (Eleocharis palustris), Baltic rush (Juncus balticus) and cattail (Typha latifolia or angustifolia). During wetter years, annuals disappear and marshes become dominated by 
emergent perennials. Common perennial forbs include common willow herb (Epilobium ciliatum), marsh cinquefoil (Potentilla palustris), Gmelin's buttercup (Ranunculus gmelinii), greater creeping spearwort (Ranunculus flammula), hemlock water parsnip (Sium suave), willow dock (Rumex salicifolius), field mint (Mentha arvensis), leafy aster (Symphyotrichum foliaceum) and broadleaf arrowhead (Sagittaria latifolia). Fern allies such as water horsetail (Equisetum fluviatile) and field horsetail (Equisetum arvense) often form significant cover within seasonal marshes. Grasses common to marshes include small floating mannagrass (Glyceria borealis), tufted hairgrass (Deschampsia caespitosa), and bluejoint reedgrass (Calamagrostis canadensis).

Seasonal and semi-permanent marshes with more alkaline water chemistry are commonly found throughout central and eastern Montana. Typical species include hardstem bulrush, cattail, common threesquare (Schoenoplectus pungens), alkali bulrush (Shoenoplectus maritimus) and inland saltgrass (Distichlis spicata), red swampfire (Salicornia rubra) and prairie cordgrass (Spartina pectinata) in adjacent drawdown zones. These marsh communities are brackish and support species adapted to saline and alkaline water and soil conditions, similar to Western Great Plains Saline Depression systems.

Typically, riverine marshes subjected to unaltered, seasonal water flow and annual flooding are characterized by zonal vegetation determined by water depth with stands of bulrush (Schoenoplectus species), softstem bulrush (Schoenoplectus tabernaemontani), and cattail in deeper water, and manna grass (Glyceria species), water sedge, inflated sedge, water horsetail and common spikerush in shallower water zones. Riverine marshes can be influenced by beaver activity and human caused influences that can change the structure and species richness of these plant communities. Beaver activity can increase species richness and diversify community structure by altering water flow, depth, and organic sediment accumulation.

\section{Dynamic Processes}

Wet-drought year climatic cycles in Montana, often in 10 to 20 year cycles, influence the ecological communities in these systems (Hansen et al., 1995). During this climatic cycle, wetlands go through a dry marsh, regenerating marsh, degenerating marsh and a lake phase that is regulated by periodic drought and deluge (Mitsch and Gosselink, 2000). During drought periods, seeds from annuals and perennials germinate and cover exposed mud flats, but when precipitation floods the depressions, the annuals drown and the perennials survive, regenerating the marsh. Over a series of years, perennials dominate and submersed and floating-leaved hydrophytes return. After a few years of the regenerating phase, emergent vegetation begins to decline and eventually the marsh reverts to an open water system. Muskrats may play an important role in the decline of emergent vegetation in some of these systems. During drought, the drawdown to mudflats is necessary so that emergent vegetation can become reestablished. Flooding, drawdown and the eventual exposure of mud flats drive the water-level vegetation cycle. In saline soil marshes, increase in precipitation during exceptionally wet years can dilute the salt concentration in the soils, allowing for less salt-tolerant species to occur.

Species richness can vary considerably among individual examples and is especially influenced by adjacent land use. Agriculture and forestry operations, when adjacent, may cause nutrient and herbicide runoff. 


\section{Management}

Changes will occur in the plant communities due to climatic conditions and/or management activities. Draining, ditching or conversion to agriculture and pastureland can alter the hydrology of the system. Moderate to Heavy grazing practices can greatly decrease cover of beaked sedge, and cause soil compaction. Invasive and exotic species such as reed canarygrass (Phalaris arundinacea), common reed (Phragmites australis) and Canadian thistle (Cirsium arvense) become established in areas of heavy grazing or other disturbances. Diversion or lateration of seasonal flooding in riverine systems can change the species composition and successional direction of riverine marsh communities.

\section{Restoration Considerations}

In marsh systems where water has been drained or altered, the original hydrology of the system must be restored. If water levels are restored, re-growth and re-colonization from dormant rhizomatous root systems of common marsh species can occur within a few years. Cattle grazing must be eliminated or controlled to allow regrowth, recolonization and resprouting from existing root systems. Many of the characteristic species found in marsh systems are rhizomatous, thus exhibit excellent erosion control properties. In some cases, if hydric soils are heavily altered due to pugging or compaction, addition of organic material may be needed to facilitate vegetation recolonization.

\section{Original Concept Authors}

Natureserve Western Ecology Group

\section{Montana Version Authors}

T. Luna., C. McIntyre, L. Vance

\section{Version Date}

$1 / 21 / 2010$

\section{Citation:}

Emergent Marsh — North American Arid West Emergent Marsh. Montana Field Guide. Retrieved on July 5, 2010, from http://FieldGuide.mt.gov/displayES_Detail.aspx?ES=9222 



\section{Appendix B. Ecological System Field Key}





\section{Field Key to Wetland and Riparian Ecological Systems of Montana}

1a. Wetland defined by groundwater inflows and peat (organic soil) accumulation of at least $40 \mathrm{~cm}$ (unless underlain by bedrock). Vegetation can be woody or herbaceous. If the wetland occurs within a mosaic of non-peat forming wetland or riparian systems, then the patch must be at least 0.1 hectares $(0.25$ acres $)$. If the wetland occurs as an isolated patch surrounded by upland, then there is no minimum size criteria Rocky Mountain Subalpine-Montane Fen

1b. Wetland does not have at least $40 \mathrm{~cm}$ of peat (organic soil) accumulation or occupies an area less than 0.1 hectares $(0.25$ acres $)$ within a mosaic of other non-peat forming wetland or riparian systems

2a. Total woody canopy cover generally $25 \%$ or more within the overall wetland/riparian area. Any purely herbaceous patches are less than 0.5 hectares and occur within a mosaic of woody vegetation. Note: Relictual woody vegetation such as standing dead trees and shrubs are included here GO TO KEY A: Woodland and Shrubland Ecological Systems

2b. Total woody canopy cover generally less than $25 \%$ within the overall wetland/riparian area. Any woody vegetation patches are less than 0.5 hectares and occur within a mosaic of herbaceous wetland vegetation GO TO KEY B: Herbaceous Ecological Systems

\section{KEY A: Woodland and Shrubland Ecological Systems}

1a. Woody wetland associated with any stream channel, including ephemeral, intermittent, or perennial (Riverine HGM Class).

1b. Woody wetland associated with the discharge of groundwater to the surface or fed by snowmelt or precipitation. This system often occurs on slopes, lakeshores, or around ponds. Sites may experience overland flow but no channel formation. (Slope, Flat, Lacustrine, or Depressional HGM Classes)

2a. Riparian woodlands and shrublands of the montane or subalpine zone 3

2b. Riparian woodlands and shrublands of the plains, foothills, or lower montane zone 4

3a. Montane or subalpine riparian woodlands (canopy dominated by trees), occurring as a narrow streamside forest lining small, confined low- to mid-order streams. Common tree species include Abies lasiocarpa, Picea engelmannii, Pseudotsuga menziesii, and Populus tremuloides. Rocky Mountain Subalpine-Montane Riparian Woodland

3b. Montane or subalpine riparian shrublands (canopy dominated by shrubs with sparse tree cover), occurring as either a narrow band of shrubs lining the streambank of steep V-shaped canyons or as a wide, extensive shrub stand (sometimes referred to as a shrub carr) on alluvial terraces in low-gradient valley bottoms. Beaver activity is common within the wider occurrences. Species of Salix, Alnus, or Betula are typically dominant ..Rocky Mountain Subalpine-Montane Riparian Shrubland

4a. Riparian woodlands and shrublands of the foothills or lower montane zones of the Northern and Middle Rockies and the Wyoming Basin

4b. Riparian woodlands and shrublands of the Northwestern or Western Great Plains of eastern Montana 
5a. Foothill or lower montane riparian woodlands and shrublands associated with mountain ranges of the Northern Rockies in northwestern Montana. This type excludes island mountain ranges east of the Continental Divide in Montana. Populus balsamifera ssp. trichocarpa is typically the canopy dominant in woodlands. Other common tree species include Populus tremuloides, Betula papyrifera, Betula occidentalis, and Picea glauca. Shrub understory species include Cornus sericea, Acer glabrum, Alnus incana, Oplopanax horridus, and Symphoricarpos albus. Areas of riparian shrubland and open wet meadow are common .......... Northern Rocky Mountain Lower Montane Riparian Woodland and Shrubland

5b. Foothill or lower montane riparian woodlands and shrublands associated with mountain ranges of the Middle Rockies and the Wyoming Basin. This type also includes island mountain ranges in central and eastern Montana. Woodlands are dominated by Populus spp. including Populus angustifolia, Populus balsamifera ssp. trichocarpa, Populus deltoides, and Populus fremontii. Common shrub species include Salix spp., Alnus incana, Crataegus spp., Cornus sericea, and Betula occidentalis ....... Rocky Mountain Lower Montane-Foothill Riparian Woodland and Shrubland

6a. Woodlands and shrublands of draws and ravines associated with permanent or ephemeral streams, steep north-facing slopes, or canyon bottoms that do not experience flooding. Common tree species include Fraxinus spp., Acer negundo, Populus tremuloides, and Ulmus spp. Important shrub species include Crataegus spp., Prunus virginiana, Rhus spp., Rosa woodsii, Symphoricarpos occidentalis, and Shepherdia argentea ..... Western Great Plains Wooded Draw and Ravine

6b. Woodlands and shrublands of small to large streams and rivers of the Northwestern or Western Great Plains. Overall vegetation is lusher than above and includes more wetland indicator species. Dominant species include Populus balsamifera ssp. trichocarpa, Populus deltoides, and Salix spp......

7a. Woodlands and shrublands of riparian areas of medium and small rivers and streams with little or no floodplain development and typically flashy hydrology .........Northwestern/Western Great Plains Riparian

7b. Woodlands and shrublands of riparian areas along medium and large rivers with extensive floodplain development and periodic flooding ...... Northwestern/Western Great Plains Floodplain

8a. Woody wetland associated with small, shallow ponds in northwestern Montana. Ponds are ringed by trees including Populus balsamifera ssp. trichocarpa, Populus tremuloides, Betula papyrifera, Abies grandis, Abies lasiocarpa, Picea engelmannii, Pinus contorta, and Pseudotsuga menziesii. Typical shrub species include Cornus sericea, Amelanchier alnifolia, and Salix spp. Northern Rocky Mountain Wooded Vernal Pool

8b. Woody wetland associated with the discharge of groundwater to the surface, or sites with overland flow but no channel formation

9a. Coniferous woodlands associated with poorly drained soils that are saturated year round or seasonally flooded. Soils can be woody peat but tend toward mineral. Common tree species include Thuja plicata, Tsuga heterophylla, and Picea engelmannii. Common species of the herbaceous understory include Mitella spp., Calamagrostis spp., and Equisetum arvense. Northern Rocky Mountain Conifer Swamp

9b. Woody wetlands dominated by shrubs .10 
10a. Subalpine to montane shrubby wetlands that occur around seeps, fens, and isolated springs on slopes away from valley bottoms. This system can also occur within a mosaic of multiple shrub- and herb-dominated communities within snowmelt-fed basins. This example of the system has the same species composition as the riverine example of this system and is dominated by species of Salix, Alnus, or Betula

Rocky Mountain Subalpine-Montane Riparian Shrubland

10b. Lower foothills to valley bottom shrublands restricted to temporarily or intermittently flooded drainages or flats and dominated by Sarcobatus vermiculatus Inter-Mountain Basins Greasewood Flat

\section{KEY B: Herbaceous Wetland Ecological Systems}

1a. Herbaceous wetlands of the Northwestern Glaciated Plains, Northwestern Great Plains, or Western Great Plains regions of eastern Montana

1b. Herbaceous wetlands of other regions

2a. Wetland occurs as a complex of depressional wetlands within the glaciated plains of northern Montana. Typical species include Schoenoplectus spp. and Typha latifolia on wetter, semi-permanently flooded sites, and Eleocharis spp., Pascopyrum smithii, and Hordeum jubatum on drier, temporarily flooded sites Great Plains Prairie Pothole

2b. Wetland does not occur as a complex of depressional wetlands within the glaciated plains of Montana

3a. Depressional wetlands in the Western Great Plains with saline soils. Salt encrustations can occur on the surface. Species are typically salt-tolerant such as Distichlis spicata, Puccinellia spp., Salicornia spp., and Schoenoplectus maritimus Western Great Plains Saline Depression Wetland

3b. Depressional wetlands in the Western Great Plains with obvious vegetation zonation dominated by emergent herbaceous vegetation, including Eleocharis spp., Schoenoplectus spp., Phalaris arundinacea, Calamagrostis canadensis, Hordeum jubatum, and Pascopyrum smithii.....

4a. Depressional wetlands in the Western Great Plains associated with open basins that have an obvious connection to the groundwater table. This system can also occurs along stream margins where it is linked to the basin via groundwater flow. Typical plant species include species of Typha, Carex, Schoenoplectus, Eleocharis, Juncus, and floating genera such as Potamogeton, Sagittaria, and Ceratophyllum .... Western Great Plains Open Freshwater Depression Wetland

4b. Depressional wetlands in the Western Great Plains primarily within upland basins having an impermeable layer such as dense clay. Recharge is typically via precipitation and runoff, so this system typically lacks a groundwater connection. Wetlands in this system tend to have standing water for a shorter duration than Western Great Plains Open Freshwater Depression Wetlands. Common species include Eleocharis spp., Hordeum jubatum, and Pascopyrum smithii Western Great Plains Closed Depression Wetland 
5a. Depressional wetlands occurring in areas with alkaline to saline clay soils with hardpans. Salt encrustations can occur on the surface. Species are typically salttolerant such as Distichlis spicata, Puccinellia spp., Leymus sp., Poa secunda, Salicornia spp., and Schoenoplectus maritimus. Communities within this system often occur in alkaline basins and swales and along the drawdown zones of lakes and ponds. Inter-Mountain Basins Alkaline Closed Depression

5b. Herbaceous wetlands not associated with alkaline to saline hardpan clay soils...

6a. Wetlands with a permanent water source throughout all or most of the year. Water is at or above the surface throughout the growing season, except in drought years. This system can occur around ponds, as fringes around lakes and along slow-moving streams and rivers. If the wetland occurs within a mosaic of wetland or riparian systems, then the patch must be at least 0.1 hectares $(0.25$ acres $)$. If the wetland occurs as an isolated patch surrounded by upland, then there is no minimum size criteria. The vegetation is dominated by common emergent and floating leaved species including species of Scirpus, Schoenoplectus, Typha, Juncus, Carex, Potamogeton, Polygonum, and Nuphar Western North American Emergent Marsh

6b. Herbaceous wetlands associated with a high water table or overland flow, but typically lacking standing water. Sites with no channel formation are typically associated with snowmelt and not subjected to high disturbance events such as flooding (Slope HGM Class). Sites associated with a stream channel are more tightly connected to overbank flooding from the stream channel than with snowmelt and groundwater discharge and may be subjected to high disturbance events such as flooding (Riverine HGM Class). Vegetation is dominated by herbaceous species; typically graminoids have the highest canopy cover including Carex spp., Calamagrostis spp., and Deschampsia cespitosa Rocky Mountain Alpine-Montane Wet Meadow 
Appendix C. Level 1 Digital Data Set Sources and Scoring 



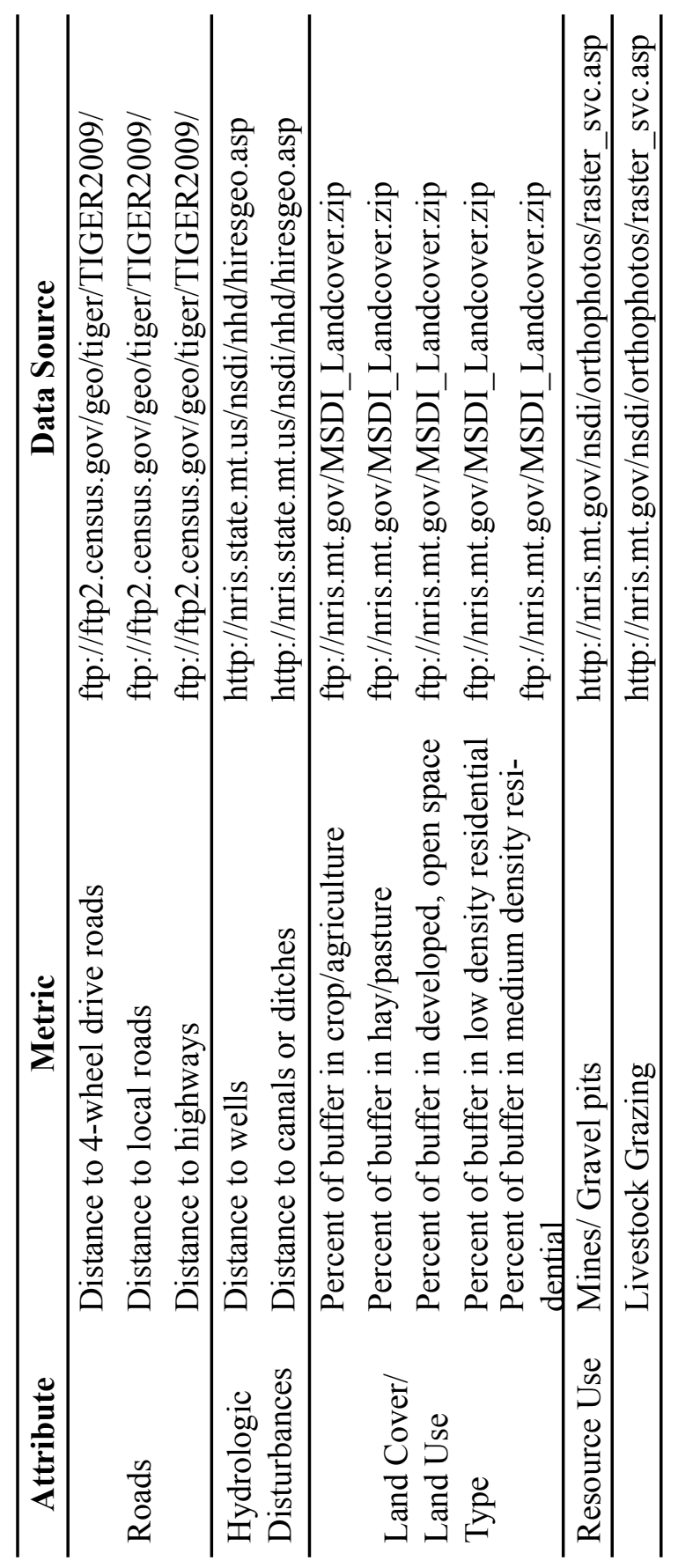

Appendix C - 1 


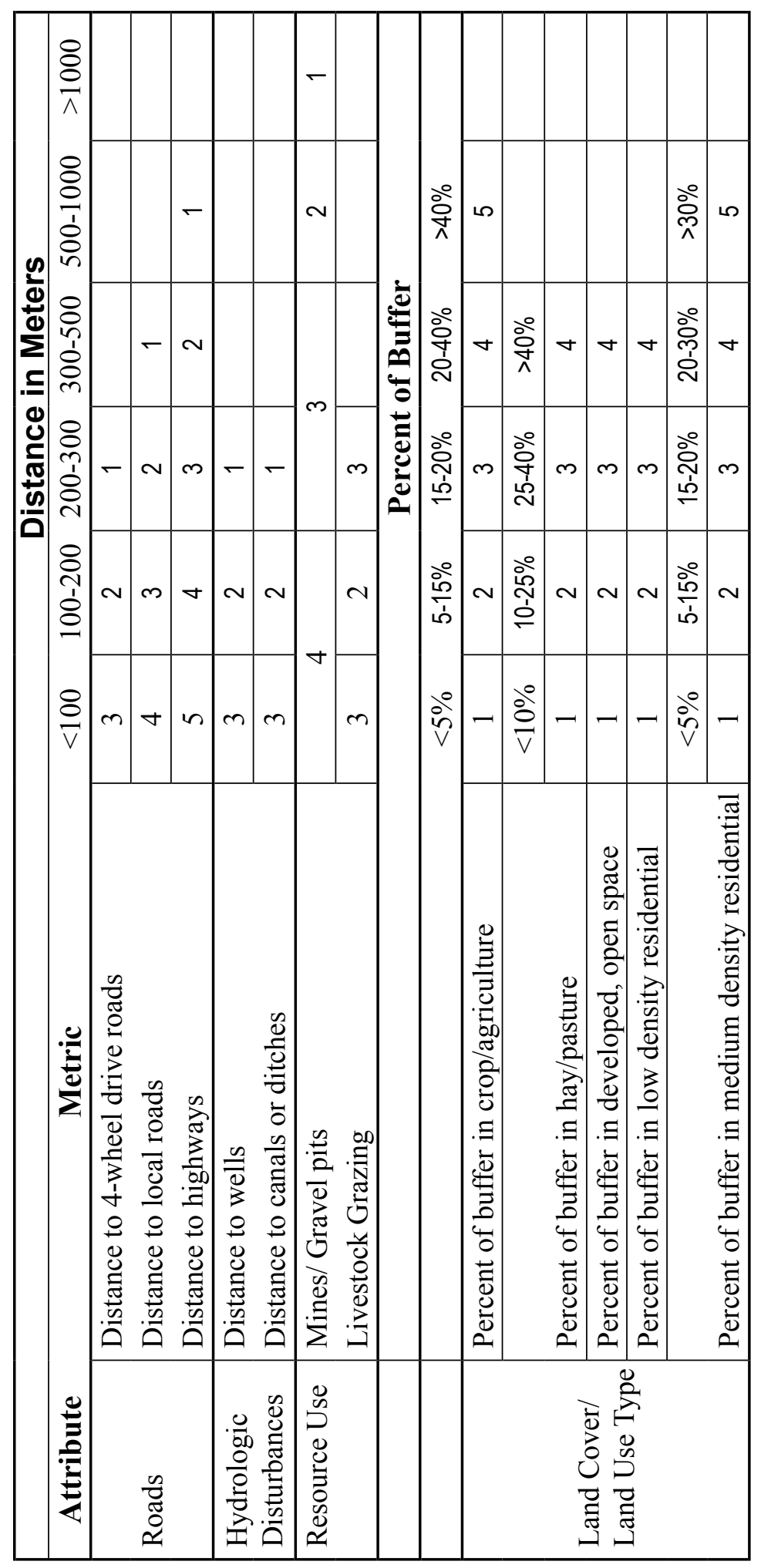

Appendix C- 2 
Appendix D. Montana Natural Heritage Program Level 2

Ecological Integrity Assessment Form 



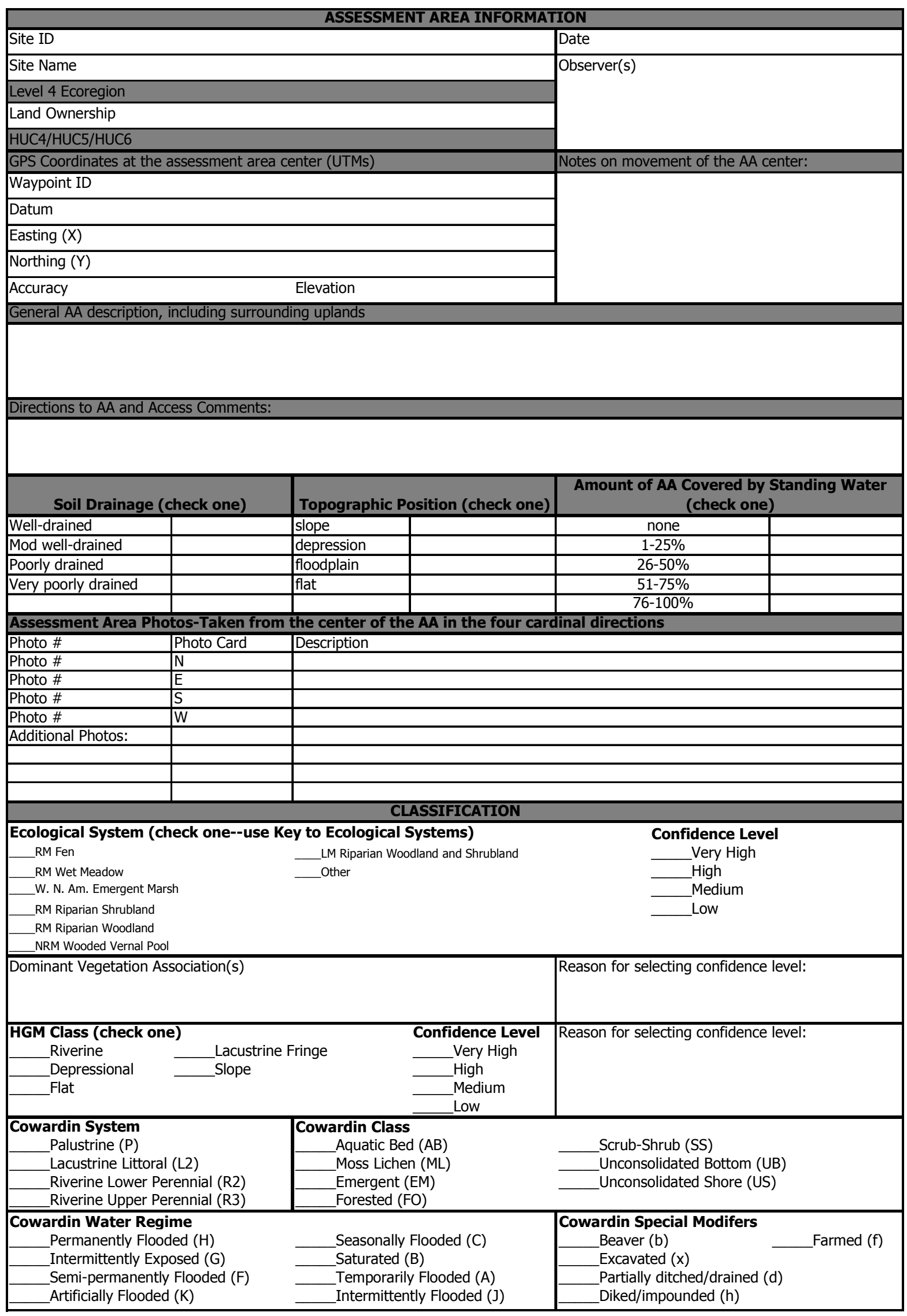


ASSESSMENT AREA DRAWING (add north arrow, document plant zones, indicate direction of drainage into or out of wetland, and include sketch of vegetation plot and soil pit placement). ALSO INDICATE ALL PLANT

ZONES ON AERIAL PHOTO, IF POSSIBLE

Notes:

Appendix D - 2 


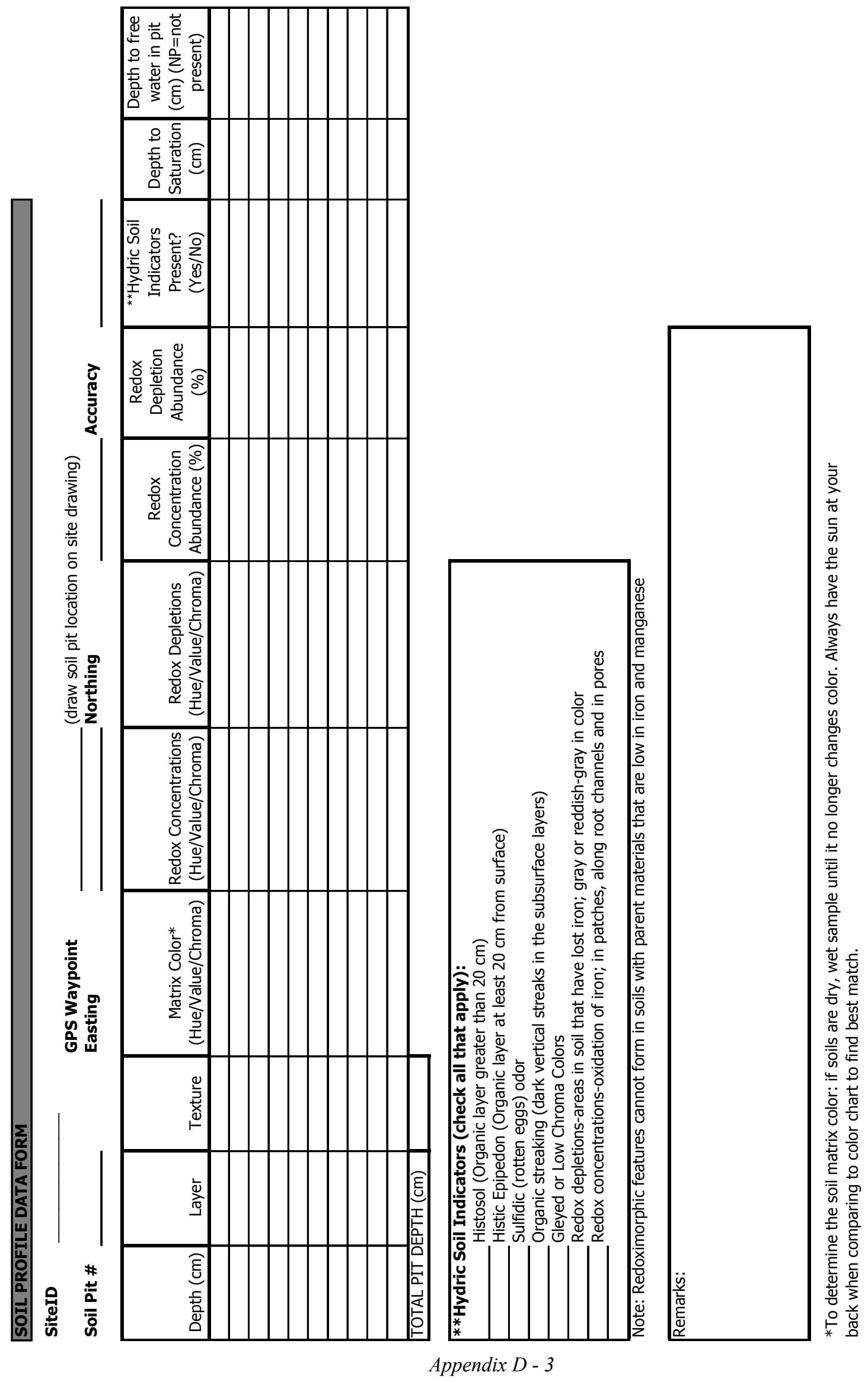




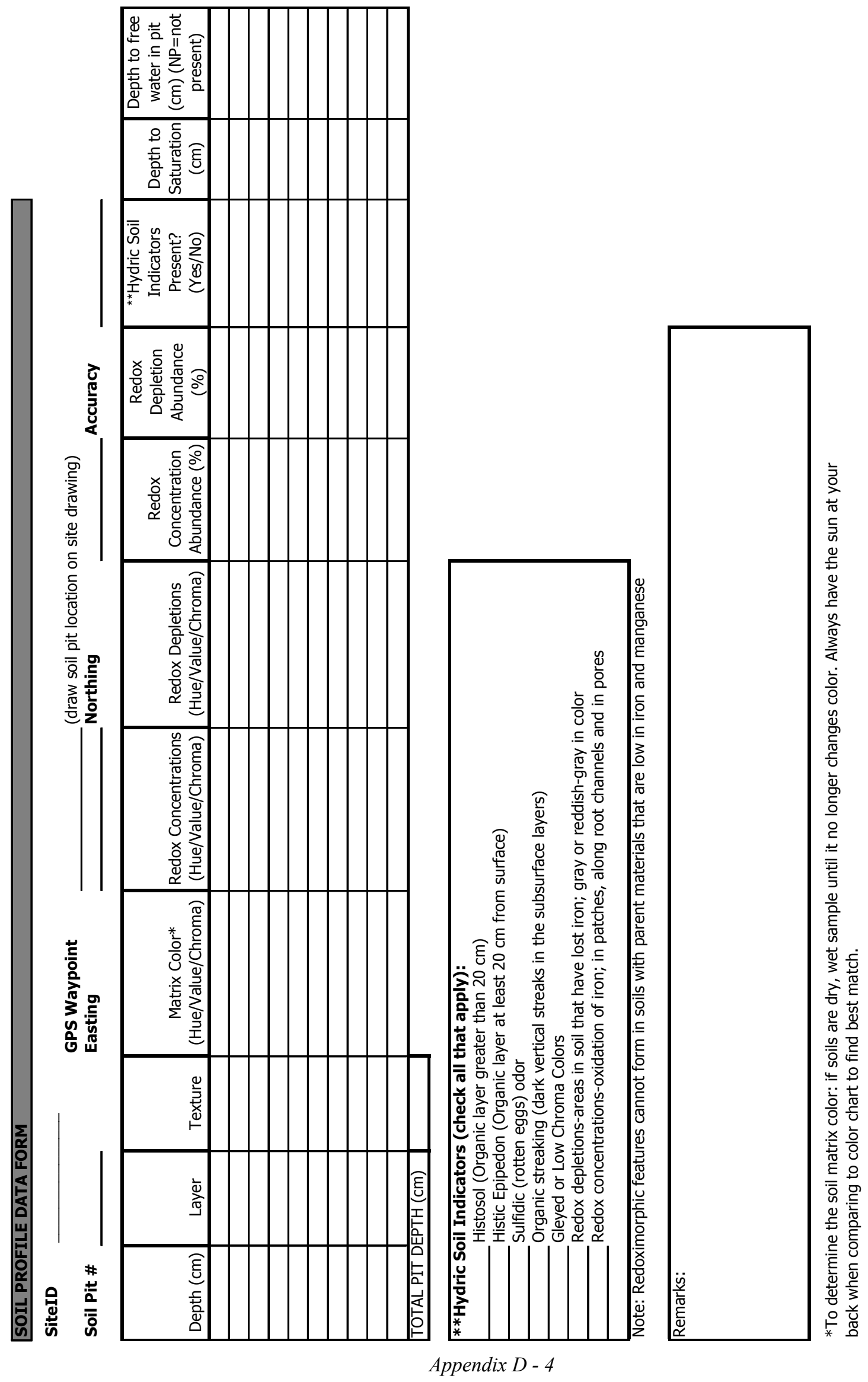




\begin{tabular}{|c|c|c|c|c|c|c|c|}
\hline \multirow{2}{*}{\multicolumn{4}{|c|}{ Height Scale for Each Plant Zone }} & \multirow{2}{*}{\multicolumn{4}{|c|}{ Cover Scale for Each Plant Zone }} \\
\hline & & & & & & & \\
\hline 1 & $<0.5 \mathrm{~m}$ & 6 & $10-15 \mathrm{~m}$ & 1 & Trace & 6 & $10-<25 \%$ \\
\hline 2 & $0.5-1 \mathrm{~m}$ & 7 & $15-20 \mathrm{~m}$ & 2 & $<1 \%$ & 7 & $25-<50 \%$ \\
\hline 3 & $1-2 m$ & 8 & $20-35 \mathrm{~m}$ & 3 & $1-<2 \%$ & 8 & $50-<75 \%$ \\
\hline 4 & $2-5 m$ & 9 & $35-50 m$ & 4 & $2-<5 \%$ & 9 & $75-<95 \%$ \\
\hline 5 & $5-10 m$ & 10 & $>50 \mathrm{~m}$ & 5 & $5-<10 \%$ & 10 & $>95 \%$ \\
\hline
\end{tabular}

Identify and describe the plant zones that occur within the assessment area. A plant zone should be described if it meets the following rules: 1a. The plant zone is dominated by a stratum distinctly different from the stratum that dominates other plant zones; OR 1b. the plant zone is dominated by the same stratum as other plant zones, BUT each plant zone is dominated by different species AND the average height of the dominant species differs by $>1 \mathrm{~m}$ (e.g., Typha latifolia vs. Juncus balticus). 2. The plant zone makes up more than $5 \%$ of the AA (e.g., 250 $\mathrm{m}^{2}$ for an AA of $0.5 \mathrm{ha}$ ). 3. Each individual patch of the plant zone is greater than $10 \mathrm{~m}^{2}$.

Plant Zone \#1 (indicate location on site drawing) Stratum

Forest/Woodland (Trees/Shrubs $>5 \mathrm{~m})$

Shrubland (Shrubs $>0.5-5 \mathrm{~m}$ )

Dwarf Shrubland $(<0.5 \mathrm{~m})$

Herbaceous (e.g., Graminoids, Forbs, Ferns)

Nonvascular (Bryophytes, cryptogamic crusts)

Submerged/Floating (Rooted or floating-exclude emergent)

Sparsely Vegetated (including bare ground)

\begin{tabular}{|l|l|l|l|}
\hline \hline Dominant Species & $\begin{array}{c}\text { Height } \\
\text { Class }\end{array}$ & $\begin{array}{c}\text { Cover } \\
\text { Class }\end{array}$ & Comments \\
\hline & & & \\
\hline & & & \\
\hline & & & \\
\hline & & & \\
\hline & & & \\
\hline & & & \\
\hline & & & \\
\hline & & & \\
\hline & & & \\
\hline & & & \\
\hline & & & \\
\hline
\end{tabular}

Stratum \#2 (indicate location on site drawing)

Stratum

Forest/Woodland (Trees/Shrubs $>5 \mathrm{~m}$ )

Shrubland (Shrubs $>0.5-5 \mathrm{~m}$ )

Dwarf Shrubland $(<0.5 \mathrm{~m})$

Herbaceous (e.g., Graminoids, Forbs, Ferns)

Nonvascular (Bryophytes, cryptogamic crusts)

Submerged/Floating (Rooted or floating-exclude emergent)

Sparsely Vegetated (including bare ground)

\begin{tabular}{|l|l|l|l|}
\hline Sparsely Vegetated (including bare ground) & $\begin{array}{c}\text { Height } \\
\text { Class }\end{array}$ & $\begin{array}{c}\text { Cover } \\
\text { Class }\end{array}$ & Comments \\
\hline & & & \\
\hline & & & \\
\hline & & & \\
\hline & & & \\
\hline & & & \\
\hline & & & \\
\hline & & & \\
\hline & & & \\
\hline & & & \\
\hline & & & \\
\hline & & & \\
\hline
\end{tabular}

Leaf Type (can check more than one)

Broad-leaved

Broad-leaved

Broad-leaved

Graminoid

Needle-leaved
Needle-leaved
Needle-leaved
Forb

Microphyllous Microphyllous Fern

Appendix D - 5 


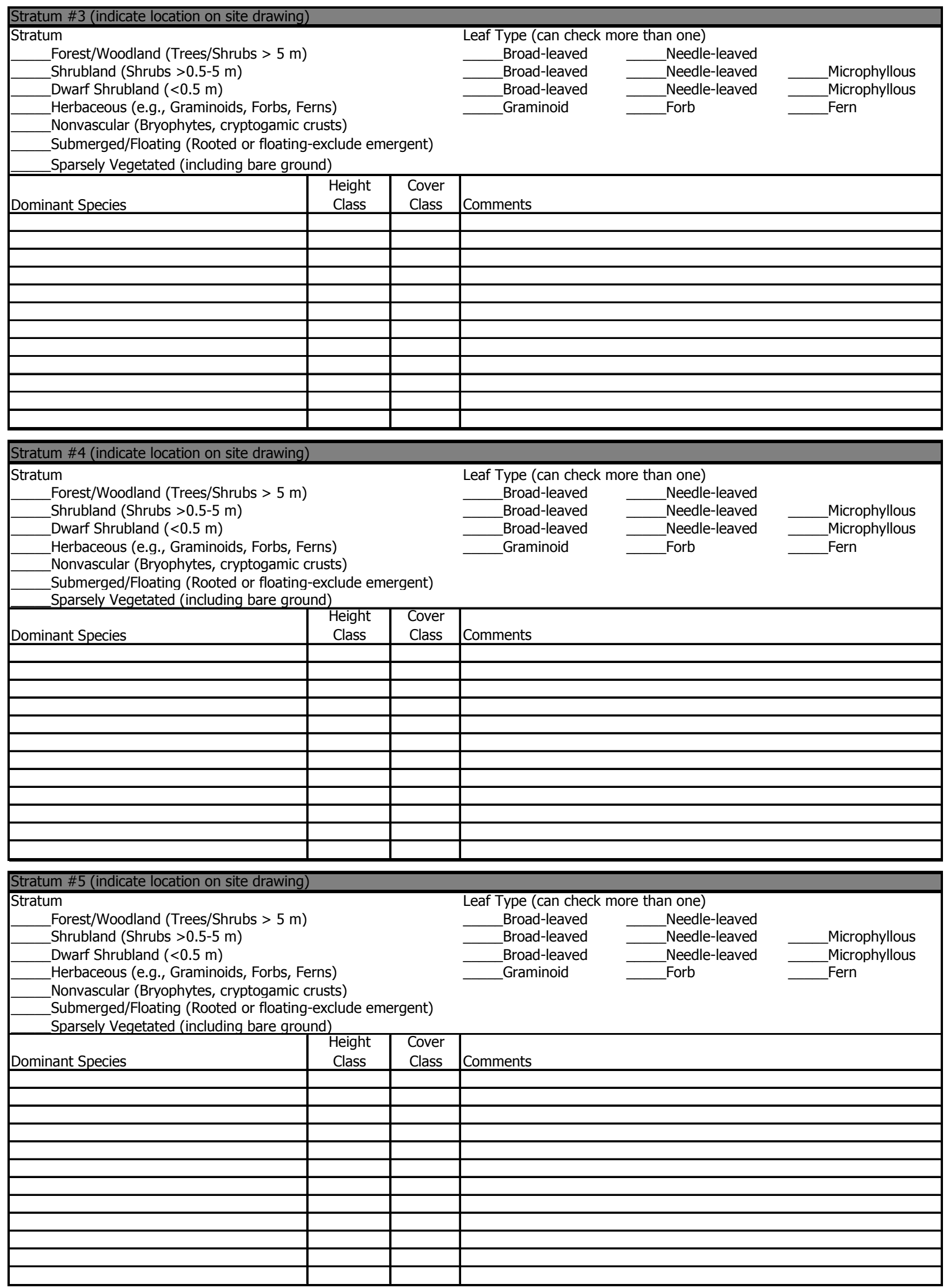




\begin{tabular}{|c|c|}
\hline \multicolumn{2}{|l|}{ LANDSCAPE CONTEXT } \\
\hline \multicolumn{2}{|l|}{ Connectivity } \\
\hline Non-riverine & $\begin{array}{l}\text { Select the statement that best describes the landscape connectivity within a } 500 \text { m buffer of the AA: 1. Intact: } \\
\text { AA embedded in } 90-100 \% \text { unfragmented, natural landscape. 2. Variegated: AA embedded in } 60-90 \% \\
\text { unfragmented, natural landscape. 3. Fragmented: AA embedded in } 20-60 \% \text { unfragmented, natural landscape. } \mathbf{4} \text {. } \\
\text { Relictual: AA embedded in }<20 \% \text { unfragmented, natural landscape. }\end{array}$ \\
\hline Riverine & $\begin{array}{l}\text { Select the statement that best describes the landscape connectivity within } 500 \text { m upstream and downstream of } \\
\text { the AA: 1. Intact: AA embedded in } 90-100 \% \text { unfragmented, natural landscape. 2. Variegated: AA embedded in } 60 \\
90 \% \text { unfragmented, natural landscape. 3. Fragmented: AA embedded in } 20-60 \% \text { unfragmented, natural } \\
\text { landscape. 4. Relictual: AA embedded in }<20 \% \text { unfragmented, natural landscape. }\end{array}$ \\
\hline \multicolumn{2}{|l|}{ Buffer } \\
\hline Length & $\begin{array}{l}\text { Select the statement that best describes the buffer length of the AA: 1. Buffer is } 76-100 \% \text { of the AA perimeter. } \\
\text { 2. Buffer is } 51-75 \% \text { of the AA perimeter. 3. Buffer is } 25-50 \% \text { of the AA perimeter. } \mathbf{4} \text {. Buffer is }<25 \% \text { of the AA } \\
\text { perimeter, OR no buffer exists. }\end{array}$ \\
\hline Width & $\begin{array}{l}\text { Select the statement that best describes the buffer width of the AA: 1. Average buffer width between edge of } \\
\text { the } A A \text { and the edge of the buffer is }>200 \mathrm{~m} \text {. 2. Average buffer width between edge of AA and the edge of the } \\
\text { buffer is }>100-200 \mathrm{~m} \text {. 3. Average buffer width between edge of the AA and the edge of the buffer is } 50-100 \mathrm{~m} \text {. } \\
\text { 4. Average buffer width between edge of the AA and the edge of the buffer is }<50 \mathrm{~m} \text {, OR no buffer exists. }\end{array}$ \\
\hline Condition & $\begin{array}{l}\text { Select the statement that best describes the buffer condition of the AA: 1. Abundant ( }>95 \%) \text { native vegetation } \\
\text { cover, little or no }(<5 \%) \text { cover of non-native plants, intact soils, AND little or no trash. } \mathbf{2} \text {. Substantial }(>75-95 \%) \\
\text { native vegetation cover, low }(5-25 \%) \text { cover of non-native plants, intact or moderately disturbed soils, moderate } \\
\text { or lesser amounts of trash, OR evidence of minor human visitation or recreation. 3. Moderate }(50-75 \%) \text { native } \\
\text { vegetation cover, moderate or extensive soil disturbance, moderate or greater amounts of trash, OR evidence of } \\
\text { moderate human visitation or recreation. } \mathbf{4} \text {. Low }(<50 \%) \text { cover of native vegetation, barren ground and highly } \\
\text { disturbed soils, moderate or greater amounts of trash, evidence of high intensity human visitation or recreation, } \\
\text { OR no buffer exists. }\end{array}$ \\
\hline \multirow[t]{2}{*}{ Buffer Condition Comments } & Describe elements that are NOT considered part of the buffer (e.g., roads, agriculture, etc.) \\
\hline & SIZE \\
\hline Relative Patch Size & $\begin{array}{l}\text { Select the statement that best describes the relative patch size of the entire wetland (current size of the } \\
\text { wetland divided by the historic size of the wetland): } \mathbf{1} \text {. Wetland is }>95 \% \text { of original size. } \mathbf{2} \text {. Wetland is }>80-95 \% \\
\text { of original size. } \mathbf{3} \text {. Wetland is }>50-80 \% \text { of original size. } \mathbf{4} \text {. Wetland is }<50 \% \text { of original size. }\end{array}$ \\
\hline Absolute Patch Size & $\begin{array}{l}\text { Estimate the size of the entire wetland (from the aerial photo OR from the GIS). IF YOU ARE UNABLE TO } \\
\text { ESTIMATE SIZE, PLEASE INDICATE ON THE FORM THAT THE SIZE SHOULD BE ESTIMATED IN THE OFFICE. }\end{array}$ \\
\hline \multicolumn{2}{|c|}{ VEGETATION STRUCTURE (BIOTA) } \\
\hline $\begin{array}{l}\text { Relative Cover of Native } \\
\text { Plant Species }\end{array}$ & 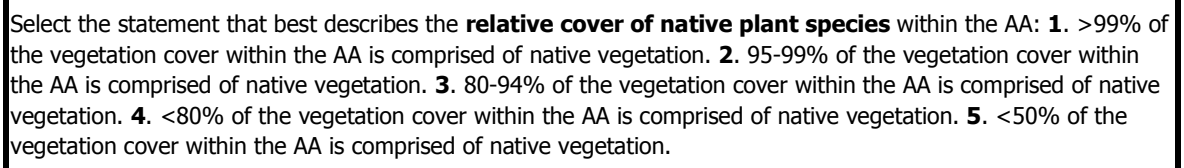 \\
\hline Invasive exotic species & $\begin{array}{l}\text { Select the statement that best describes invasive exotic species within the AA: } \mathbf{1 .}<1 \% \text { of the vegetation cover } \\
\text { within the AA is comprised of invasive exotic species. } \mathbf{2} .1-3 \% \text { of the vegetation cover within the AA is comprised } \\
\text { of invasive exotic species. } 3 .>3-5 \% \text { of the vegetation cover within the AA is comprised of invasive exotic species. } \\
\text { 4. }>5 \% \text { of the vegetation cover within the AA is comprised of invasive exotic species. }\end{array}$ \\
\hline $\begin{array}{l}\text { Invasive or highly } \\
\text { tolerant natives }\end{array}$ & $\begin{array}{l}\text { Select the statement that best describes the invasive or highly tolerant natives within the AA: } \mathbf{1} .<5 \% \text { of the } \\
\text { vegetation cover within the AA is comprised of invasive or tolerant native plant species. } \mathbf{2 .} 5-10 \% \text { of the } \\
\text { vegetation cover within the AA is comprised of invasive or tolerant native plant species. } \mathbf{3} .>10-25 \% \text { of the } \\
\text { vegetation cover within the AA is comprised of invasive or tolerant native plant species. } \mathbf{4} .>25 \% \text { of the } \\
\text { vegetation cover within the AA is comprised of invasive or tolerant native plant species. }\end{array}$ \\
\hline
\end{tabular}




\begin{tabular}{|c|c|}
\hline $\begin{array}{l}\text { Organic Matter } \\
\text { Accumulation }\end{array}$ & $\begin{array}{l}\text { Select the statement that best describes the organic matter accumulation of the site: } \mathbf{1} \text {. Site has moderate } \\
\text { amount of fine organic matter. New growth is more prevalent than previous years' growth. Layers of litter in pools } \\
\text { or areas of topographic lows are thin. } \mathbf{2} \text {. Site is characterized by small amounts of coarse organic debris, with little } \\
\text { plant recruitment, OR debris is somewhat excessive. 3. Site has little coarse debris and/or only scant fine debris } \\
\text { OR debris is excessive. }\end{array}$ \\
\hline Physical Patch Types & How many physical patch types occur within the site (refer to physical patch type table)? \\
\hline Patch Interspersion & $\begin{array}{l}\text { Select the statement that best describes the patch interspersion of the site: } \mathbf{1} \text {. Horizontal structure consists of a } \\
\text { very complex array of nested or interspersed irregular biotic/abiotic patches with no single dominant type. } \mathbf{2 .} \\
\text { Horizontal structure consists of a moderately complex array of nested or interspersed irregular biotic/abiotic } \\
\text { patches with no single dominant type. 3. Horizontal structure consists of a simple array of nested or interspersed } \\
\text { irregular biotic/abiotic patches with no single dominant type. } \mathbf{4} \text {. Horizontal structure consists of one dominant } \\
\text { patch type with no interspersion. }\end{array}$ \\
\hline \multicolumn{2}{|l|}{ PHYSICOCHEMICAL } \\
\hline Soil Surface Integrity & $\begin{array}{l}\text { Select the statement that describes the soil surface integrity of the site: } \mathbf{1} \text {. Bare soil is limited to naturally } \\
\text { caused disturbances such as flood deposition or game trails. 2. Some bare soil due to human causes (including } \\
\text { livestock) is present but the extent and impact is minimal. The depth of disturbance is limited to only a few inches } \\
\text { and does not show evidence of ponding or channeling water. Any disturbance is likely to recover within a few } \\
\text { years after the disturbance is removed. } 3 \text {. Bare soil due to human causes is common and will be slow to recover. } \\
\text { There may be pugging due to livestock resulting in several inches of soil disturbance. ORVs or other machinery } \\
\text { may have left some shallow ruts. Damage is not excessive and the site will recover with the removal of degrading } \\
\text { human influences and moderate recovery times. 4. Bare soil substantially degrades the site due to altered } \\
\text { hydrology or other long-lasting impacts. Deep ruts from ORVs or machinery may be present, or livestock pugging } \\
\text { and/or trails are widespread. Water, if present, would be channeled or ponded. The site will not recover without } \\
\text { restoration and/or long recovery times. }\end{array}$ \\
\hline Water Quality & $\begin{array}{l}\text { Select the statement that best describes the water quality of the site: 1. No visual evidence of degraded water } \\
\text { quality. Wetland species that respond to high nutrient levels are minimally present, if at all. Water is clear with no } \\
\text { strong green tint or sheen. } \mathbf{2} \text {. Some negative water quality indicators are present, but limited to small and } \\
\text { localized areas within the wetland. Wetland species that respond to high nutrient levels may be present but are } \\
\text { not dominant. Water may have a minimal greenish tint, cloudiness, or sheen. 3. Negative water quality indicators } \\
\text { or wetland species that respond to high nutrient levels are common. Sources of water quality degradation are } \\
\text { apparent. Water may have a moderate greenish tint, sheen or other turbidity with algae common. } \mathbf{4} \text {. Wetland is } \\
\text { dominated by vegetation species that respond to high nutrient levels or there is widespread evidence of other } \\
\text { negative water quality indicators. Algal mats may be extensive, blocking light to the bottom. Sources of water } \\
\text { quality degradation are typically apparent. Water has strong greenish tint, sheen, or turbidity. The bottom difficult } \\
\text { to see during the growing season. }\end{array}$ \\
\hline \multicolumn{2}{|l|}{ HYDROLOGY } \\
\hline Water Source & $\begin{array}{l}\text { Select the statement that best describes the water source under dry season conditions of the AA: } \mathbf{1 .} \\
\text { Sources are precipitation, groundwater, and/or natural runoff, or natural flow from an adjacent freshwater body, } \\
\text { or the AA naturally lacks water in the dry season. 2. Sources are mostly natural but can include occasional or } \\
\text { small effects of modified hydrology (e.g., developed land or irrigated agricultural land comprising less than } 20 \% \text { of } \\
\text { the drainage basin within } 2 \mathrm{~km} \text { of the AA, presence of a few small stormdrains or scattered homes with septic } \\
\text { systems). No large point sources or dams control the overall hydrology. 3. Sources or withdrawals are primarily } \\
\text { from anthropogenic sources (e.g., urban runoff, direct irrigation, diversions, pumped water, impoundments, } \\
\text { regulated releases through a dam, developed or irrigated agricultural land comprising more than } 20 \% \text { of the } \\
\text { drainage basin within } 2 \mathrm{~km} \text { of the AA, presence of major drainage point source discharges that obviously control } \\
\text { the hydrology of the AA). } \mathbf{4} \text {. Natural sources have been eliminated based on the following indicators: } \\
\text { impoundment of all wet season inflows, diversions of all dry-season inflows, predominance of xeric vegetation, etc. }\end{array}$ \\
\hline $\begin{array}{l}\text { Hydroperiod (for } \\
\text { depressional, lacustrine, } \\
\text { and slope wetlands--NOT } \\
\text { fens) }\end{array}$ & $\begin{array}{l}\text { Which of the following statements best describes the hydroperiod of the site: 1. Hydroperiod of the AA is } \\
\text { characterized by natural patterns of filling or inundation and drying or drawdowns. 2. The filling or inundation } \\
\text { patterns in the AA are of greater magnitude or duration than would be expected under natural conditions, but } \\
\text { thereafter the AA is subject to natural drawdown or drying. 3. Hydroperiod of the AA is characterized by natural } \\
\text { patterns of filling or inundation, but thereafter, is subject to more rapid or extreme drawdown or drying, as } \\
\text { compared to more natural wetlands. OR The filling or inundation patterns in the AA are of substantially lower } \\
\text { magnitude or duration than would be expected under natural conditions, but thereafter, the AA is subject to } \\
\text { natural drawdown or drying. 4. Both the inundation and drawdown of the AA deviate from natural conditions } \\
\text { (either increased or decreased in magnitude and/or duration). }\end{array}$ \\
\hline
\end{tabular}




\begin{tabular}{|c|c|}
\hline Hydroperiod (for fens) & $\begin{array}{l}\text { Select the statement that best describes the hydroperiod of the site: } \mathbf{1} \text {. Hydroperiod of the site is characterized } \\
\text { by stable, saturated hydrology, or by naturally damped cycles of saturation and partial drying. 2. Hydroperiod of } \\
\text { the site experiences minor altered inflows or drawdown/drying, as compared to more natural wetlands (e.g., } \\
\text { ditching). 3. Hydroperiod of the site is somewhat altered by greater increased inflow from runoff, or experiences } \\
\text { moderate drawdown or drying, as compared to more natural wetlands (e.g., ditching). 4. Hydroperiod of the site } \\
\text { is greatly altered by increased inflow from runoff or experiences large drawdown or drying, as compared to more } \\
\text { natural wetlands (e.g., ditching). }\end{array}$ \\
\hline $\begin{array}{l}\text { Hydroperiod (for riverine } \\
\text { sites) }\end{array}$ & $\begin{array}{l}\text { Select the statement that best describes the hydroperiod of the site (based on field indicators in the worksheet): } \\
\text { 1. Most of the channel through the AA is characterized by equilibrium conditions, with little evidence of } \\
\text { aggradation or degradation. 2. Most of the channel through the AA is characterized by some aggradation or } \\
\text { degradation, none of which is severe, and the channel seems to be approaching an equilibrium form. } 3 \text {. There is } \\
\text { evidence of severe aggradation or degradation of most of the channel through the AA, or the channel is artificially } \\
\text { hardened through less than half of the AA. } 4 \text {. The channel is concrete or otherwise artificially hardened through } \\
\text { most of the AA. }\end{array}$ \\
\hline $\begin{array}{l}\text { Groundwater } \\
\text { Connectivity }\end{array}$ & $\begin{array}{l}\text { Are there areas within the assessment area buffer that indicate groundwater connectivity (e.g., visually confirmed, } \\
\text { temporary surface water connection to an upslope wetland; areas of vigorous growth of upland vegetation relative } \\
\text { to the surrounding uplands). }\end{array}$ \\
\hline $\begin{array}{l}\text { Hydrologic Connectivity } \\
\text { (for depressional, } \\
\text { lacustrine, and slope } \\
\text { wetlands--NOT isolated } \\
\text { fens) }\end{array}$ & $\begin{array}{l}\text { Select the statement that best describes the hydrologic connectivity of the site: } \mathbf{1} \text {. Rising water in the AA has } \\
\text { unrestricted access to adjacent areas without levees or other obstructions to the lateral movement of flood } \\
\text { waters. } 2 \text {. Unnatural features such as levees or road grades limit the amount of adjacent transition zone or the } \\
\text { lateral movement of floodwaters, relative to what is expected for the setting, but the limitations exist for less than } \\
50 \% \text { of the AA perimeter. Restrictions may be intermittent along the margins of the AA, or they may occur only } \\
\text { along one bank or shore. 3. The amount of adjacent transition zone or the lateral movement of flood waters to } \\
\text { and from the AA is limited, relative to what is expected for the setting, by unnatural features such as levees or } \\
\text { road grades, for } 50-90 \% \text { of the AA perimeter. Flood flows may exceed the obstructions, but drainage out of the } \\
\text { AA is probably obstructed. } \mathbf{4} \text {. The amount of adjacent transition zone or the lateral movement of flood waters is } \\
\text { limited, relative to what is expected for the setting, by unnatural features such as levees or road grades, for more } \\
\text { than } 90 \% \text { of the AA perimeter. }\end{array}$ \\
\hline $\begin{array}{l}\text { Hydrologic Connectivity } \\
\text { (for naturally isolated } \\
\text { fens) }\end{array}$ & $\begin{array}{l}\text { Select the statement that best describes the hydrologic connectivity of the site: } \mathbf{1} \text {. No natural connectivity with } \\
\text { the surrounding water bodies. } 2 \text {. Partial connectivity (e.g., ditching or draining to dry the fen). } \mathbf{3} \text {. Substantial to } \\
\text { full connectivity that has obvious effects of drying the peat body. }\end{array}$ \\
\hline $\begin{array}{l}\text { Hydrologic Connectivity } \\
\text { (for confined riverine } \\
\text { wetlands) }\end{array}$ & $\begin{array}{l}\text { Select the statement that best describes the hydrologic connectivity of the site based on the entrenchment } \\
\text { ratio calculation: } \mathbf{1} \text {. Entrenchment ratio }>2.0 \text {. 2. Entrenchment ratio 1.6-2.0. 3. Entrenchment ratio 1.2-1.5. 4. } \\
\text { Entrenchment ratio }<1.2 \text {. }\end{array}$ \\
\hline $\begin{array}{l}\text { Hydrologic Connectivity } \\
\text { (for unconfined riverine } \\
\text { wetlands) }\end{array}$ & $\begin{array}{l}\text { Select the statement that best describes the hydrologic connectivity of the site based on the entrenchment } \\
\text { ratio calculation: } \mathbf{1} \text {. Entrenchment ratio }>2.2 \text {. 2. Entrenchment ratio 1.9-2.2. 3. Entrenchment ratio 1.5-1.8. 4. } \\
\text { Entrenchment ratio }<1.5 \text {. }\end{array}$ \\
\hline
\end{tabular}




\begin{tabular}{|l|l|}
\hline PHYSICAL PATCH TYPE & $\begin{array}{c}\text { CHECK } \\
\text { ONE }\end{array}$ \\
\hline Open water-pond or lake & \\
\hline Open water -pools & \\
\hline Open water-river/stream & \\
\hline Open water-oxbow/backwater channel & \\
\hline Open water-tributary/secondary channel & \\
\hline Open water-beaver pond & \\
\hline Deep emergent plants (> 0.5 m water depth) & \\
\hline Shallow emergent plants (<0.5 m water depth) & \\
\hline Submerged/floating vegetation & \\
\hline Active beaver dam & \\
\hline Adjacent or onsite springs/seeps & \\
\hline Shrubs/Trees & \\
\hline Transitional meadow & \\
\hline Saline meadow & \\
\hline Debris jams/woody debris & \\
\hline Pool/riffle complex & \\
\hline Point bars & \\
\hline Mudflats & \\
\hline Wet meadow patches & \\
\hline Plant hummocks/sediment mounds & \\
\hline Water tracks/hollows & \\
\hline Tall herbaceous vegetation $(>0.5 \mathrm{~m}$ tall) & \\
\hline Low herbaceous vegetation $(<0.5 \mathrm{~m}$ tall) & \\
\hline Floating mat & \\
\hline Vegetation cover dominated by sedges/moss & \\
\hline Number of observed patches & \\
\hline
\end{tabular}




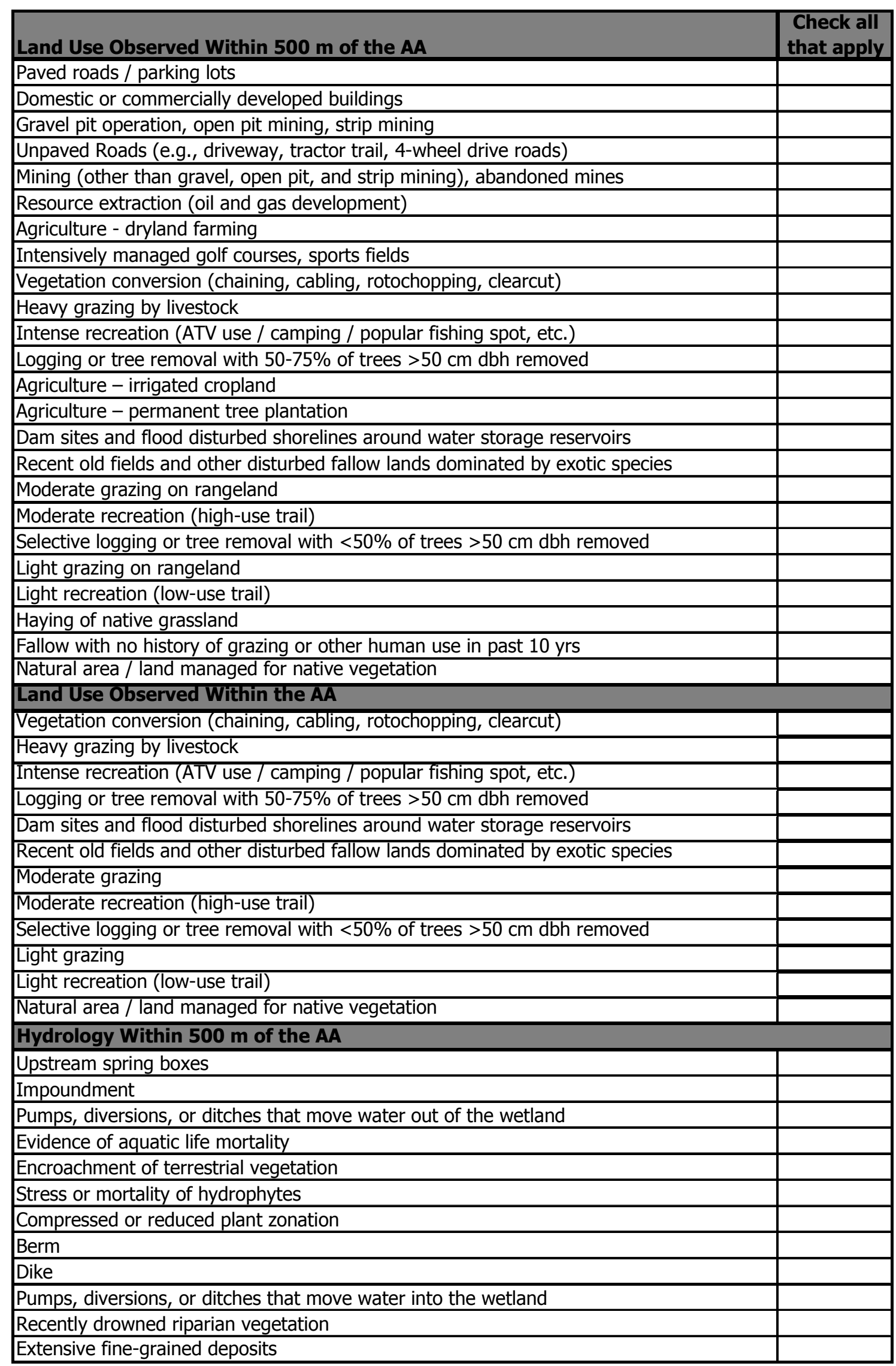

Appendix D - 11 


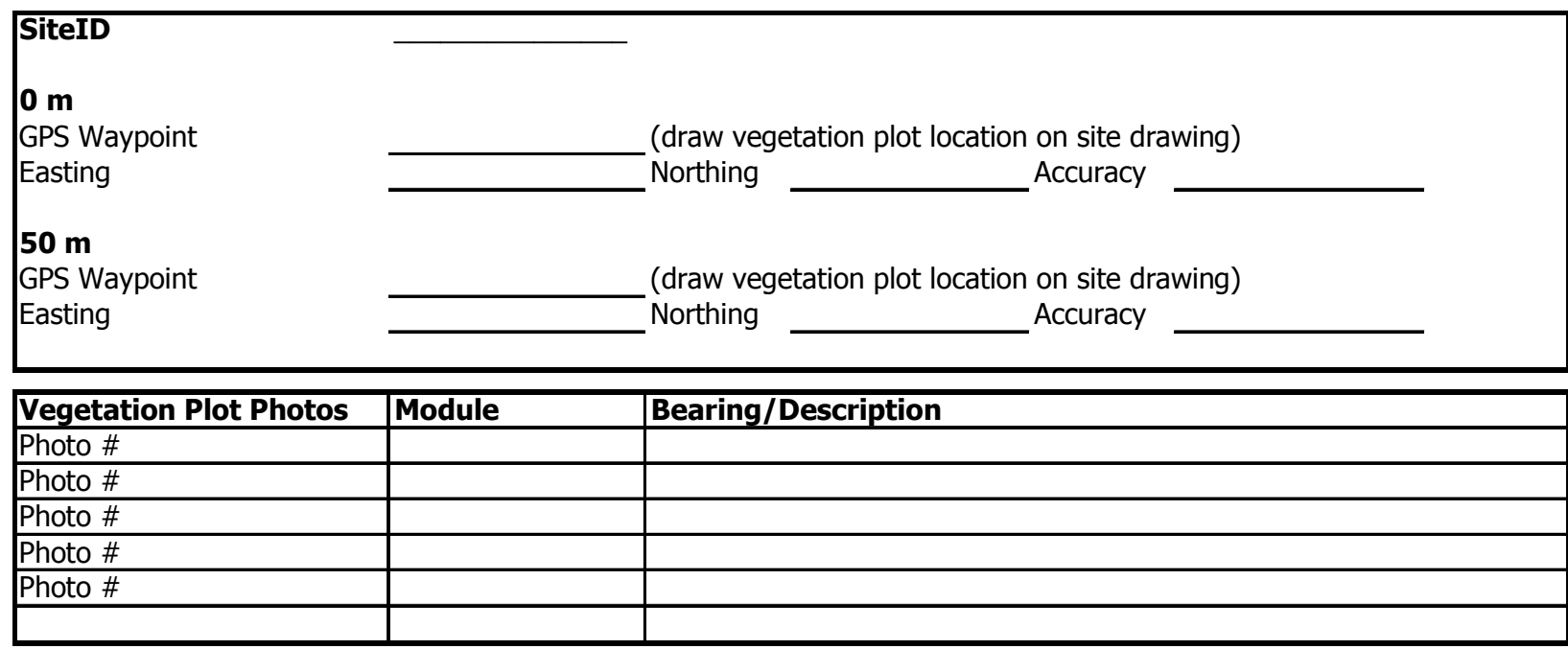

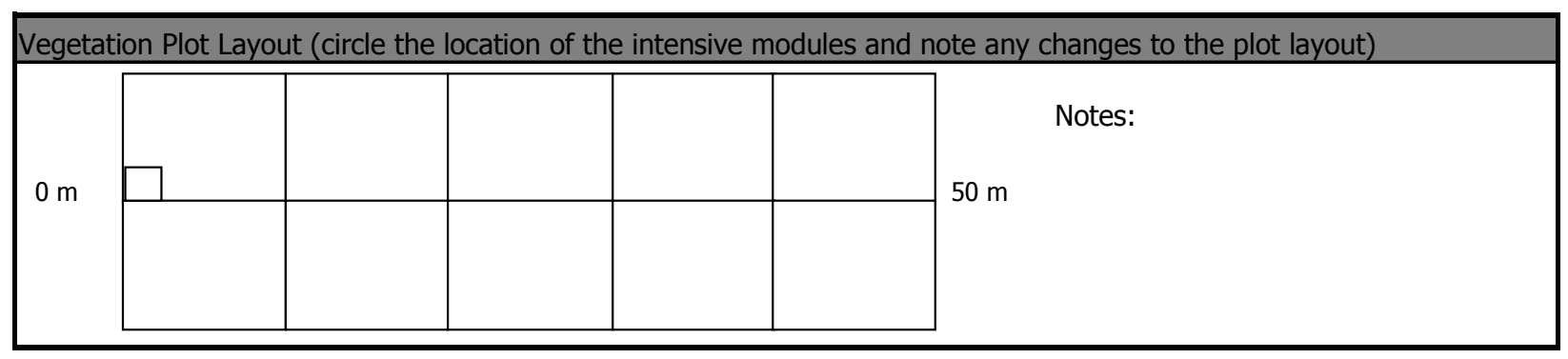

Plot Representativeness (discuss decisions for placement and/or whether the plot is representative of the assessment area) 


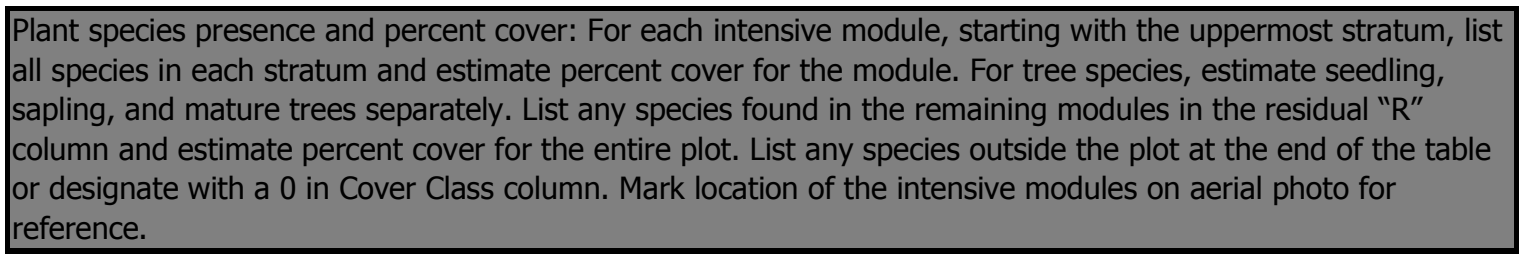

\begin{tabular}{|l|l|l|l|}
\hline Cover Scale for Strata & \multicolumn{3}{l|}{} \\
\hline 1 & Trace & 6 & $10-<25 \%$ \\
\hline 2 & $<1 \%$ & 7 & $25-<50 \%$ \\
\hline 3 & $1-<2 \%$ & 8 & $50-<75 \%$ \\
\hline 4 & $2-<5 \%$ & 9 & $75-<95 \%$ \\
\hline 5 & $5-<10 \%$ & 10 & $>95 \%$ \\
\hline
\end{tabular}

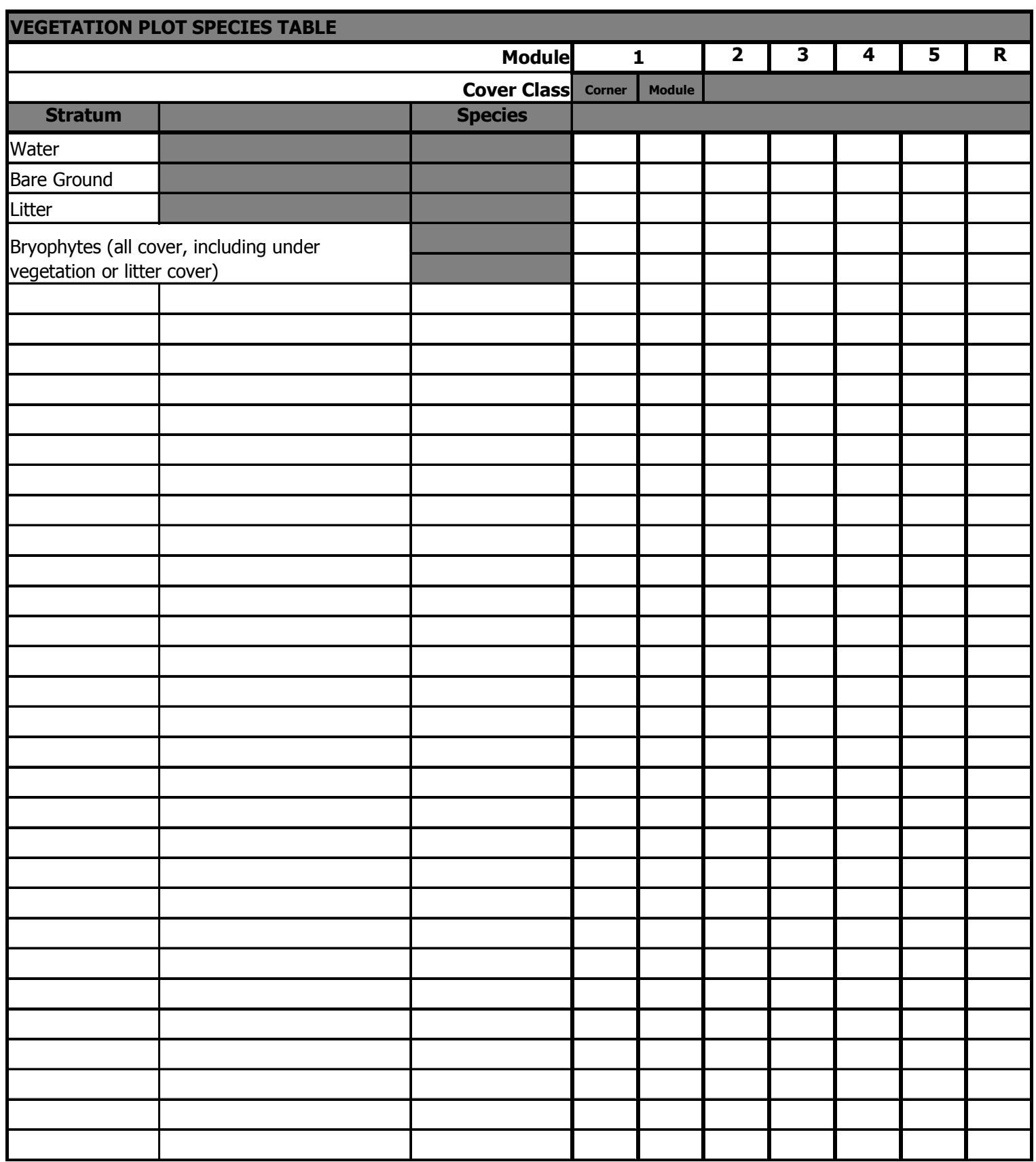

Appendix D - 13 

Appendix E. Calculation of Level 2 Attribute and Overall AA Scores 

1. For each metric, convert narrative rating score $(1,2,3$, and 4$)$ into the corresponding metric score: $1=12,2=9,3=6$, and $4=3$.

2. Each final attribute score was calculated according to the following:

Landscape Context (LC) Attribute Score:

Raw score $=\left[\text { Buffer Condition } \mathrm{x}(\text { Buffer width } \mathrm{x} \text { Buffer length })^{1 / 2}\right]^{1 / 2}+$ Landscape Connectivity

Final Attribute score $=$ Raw Landscape Context Score $\mathrm{x} 100$

Total possible points allowed (24)

Relative Patch Size Attribute Score:

Final Attribute score $=$ Relative Patch Size Score $\mathrm{x} 100$ Total possible points allowed (12)

Biotic Attribute Score:

Raw score $=($ Invasive native + Native + Invasive scores $)+\mathrm{OM}$ accumulation + patch interspersion 3

Final Attribute Score $=$

Raw Biotic Score $\mathrm{x} 100$

Total possible points allowed (36)

Hydrology Attribute Score:

Raw score $=$ Hydrological Source + Hydroperiod + Hydrologic Connectivity scores

Final Attribute Score $=$ Raw Hydrology Score $\mathrm{x} 100$

Total possible points allowed (36)

Physicochemical Attribute Score:

Raw score $=$ Soil Surface Integrity + Water Quality scores

Final Attribute Score $=$ Raw Physicochemical Score $\mathrm{x} 100$ Total possible points allowed (24)

3. Final AA Score $=\underline{\text { Final LC }+ \text { Final Patch Size }+ \text { Final Biotic }+ \text { Final Hydro }+ \text { Final Physicochemical }}$ 5 $\underline{\text { score }}$ 



\section{Appendix F. Montana Natural Heritage Program Level 3 Intensive Vegetation Assessment Form}





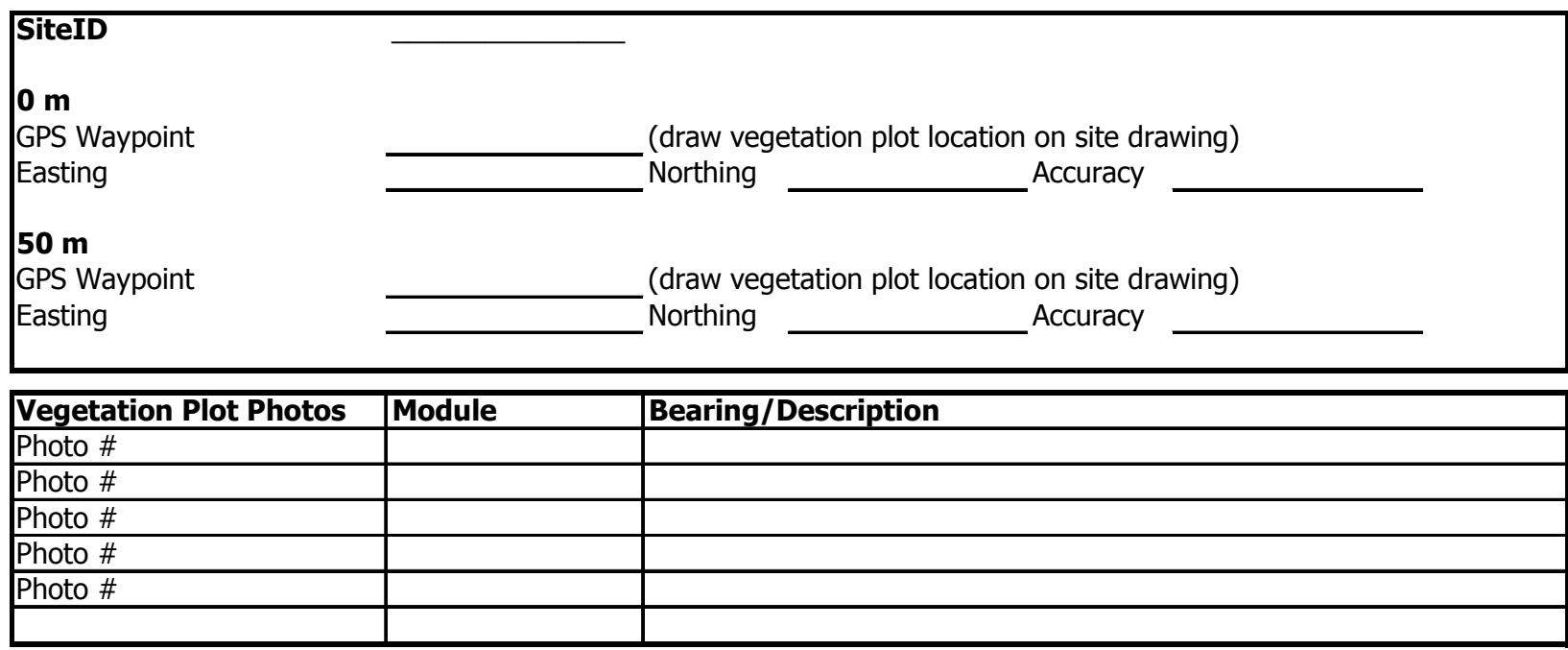

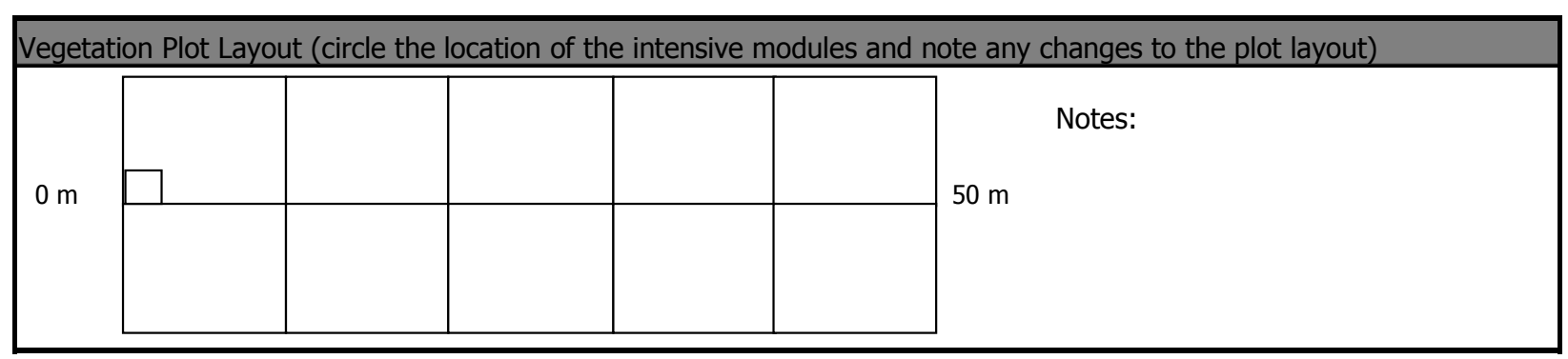

\section{Plot Representativeness (discuss decisions for placement and/or whether the plot is representative of the assessment} area) 
Plant species presence and percent cover: For each intensive module, starting with the uppermost stratum, list all species in each stratum and estimate percent cover for the module. For tree species, estimate seedling, sapling, and mature trees separately. List any species found in the remaining modules in the residual " $\mathrm{R}^{\text {" }}$ column and estimate percent cover for the entire plot. List any species outside the plot at the end of the table or designate with a 0 in Cover Class column. Mark location of the intensive modules on aerial photo for reference.

\begin{tabular}{|l|l|l|l|}
\hline \multicolumn{4}{|l|}{ Cover Scale for Strata } \\
\hline 1 & Trace & 6 & $10-<25 \%$ \\
\hline 2 & $<1 \%$ & 7 & $25-<50 \%$ \\
\hline 3 & $1-<2 \%$ & 8 & $50-<75 \%$ \\
\hline 4 & $2-<5 \%$ & 9 & $75-<95 \%$ \\
\hline 5 & $5-<10 \%$ & 10 & $>95 \%$ \\
\hline
\end{tabular}

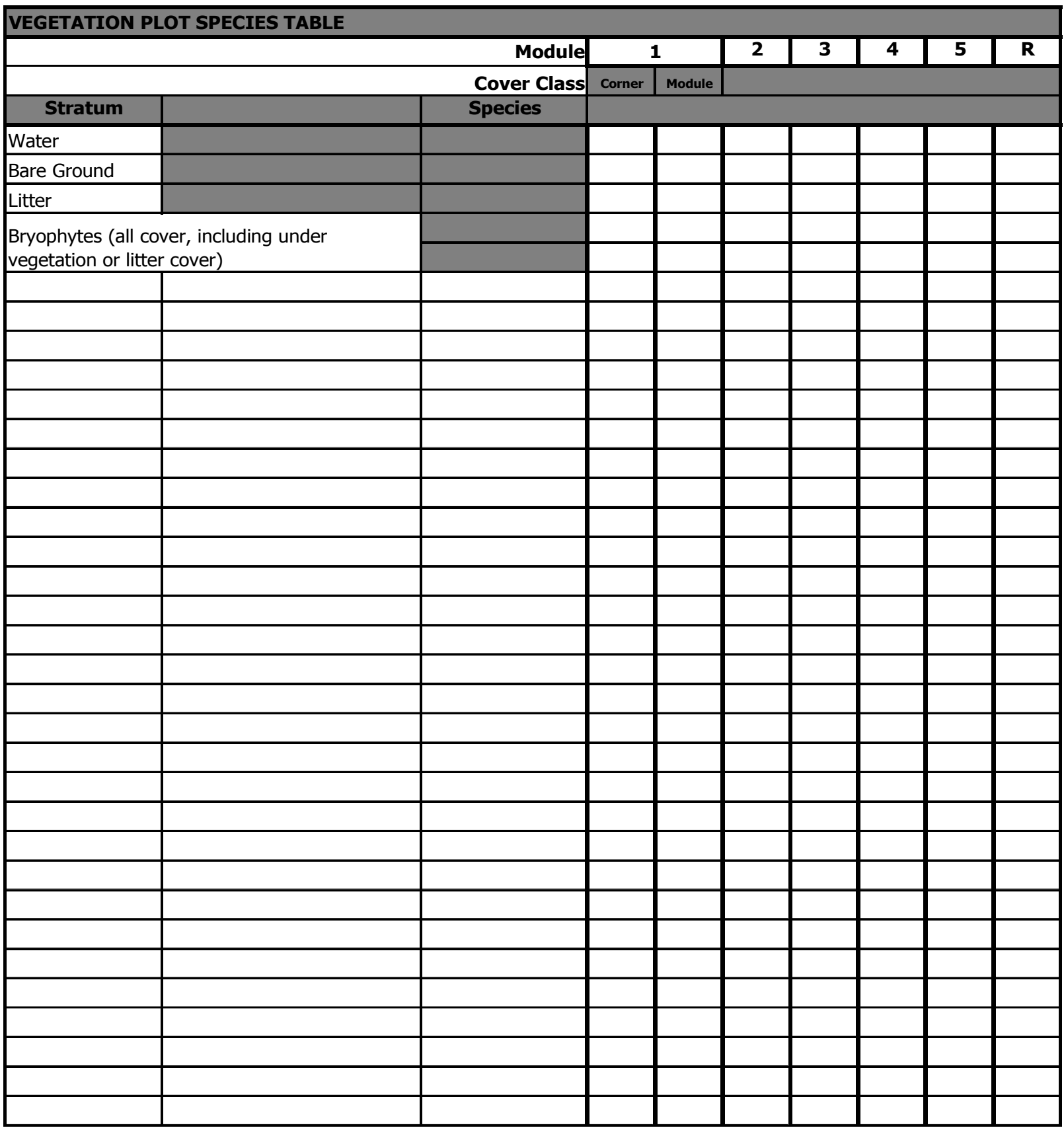

Appendix F - 2 
Appendix G. Vegetation Cover Classes and Relevé layout 

The following cover classes were used to estimate vegetation cover:

$\begin{array}{ll}1=\text { trace (one individual) } & 6 \geq 10-25 \% \\ 2<1 \% & 7 \geq 25-50 \% \\ 3 \geq 1-2 \% & 8 \geq 50-75 \% \\ 4 \geq 2-5 \% & 9 \geq 75-95 \% \\ 5 \geq 5-10 \% & 10 \geq 95 \%\end{array}$

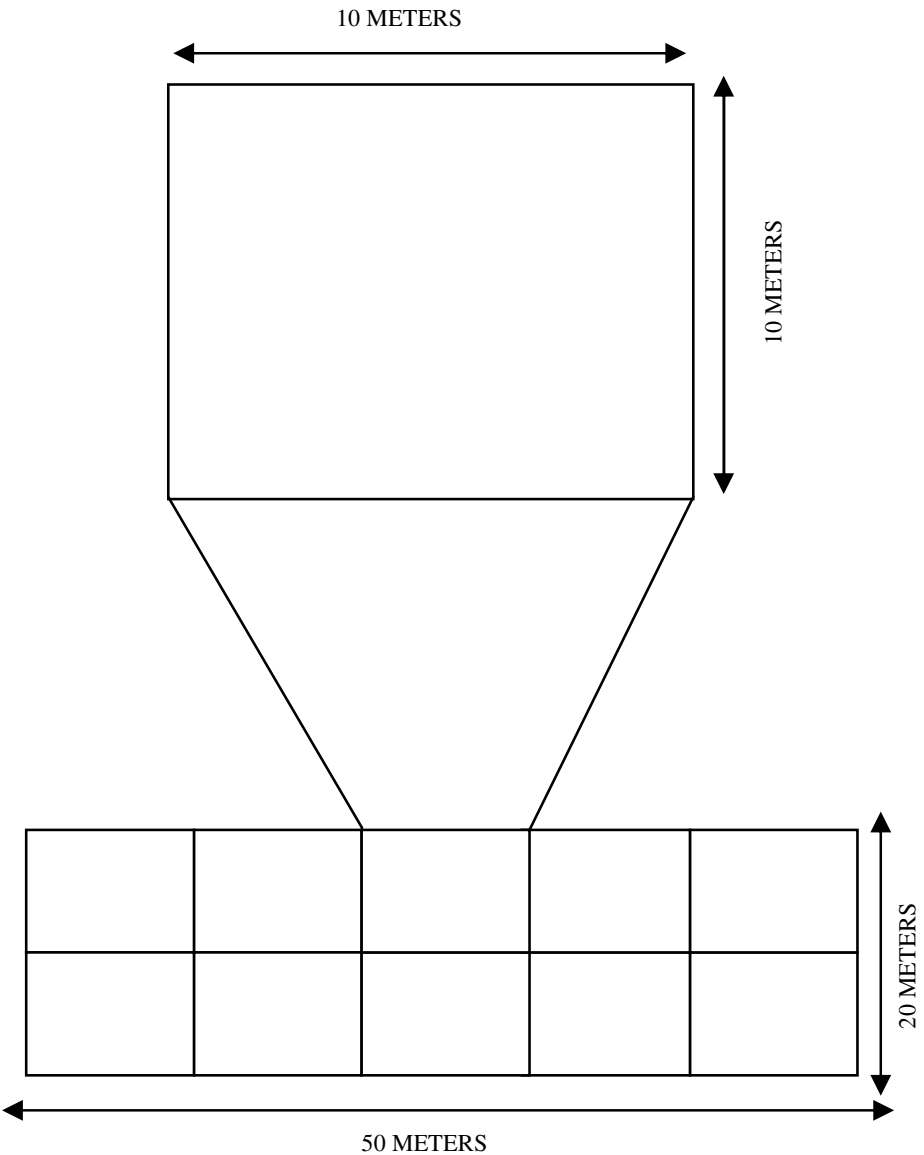





\section{Appendix H. Calculation and Description of Floristic Quality Assessment Indices}



Indices

Total species Richness

Native species richness

Non-native species richness

Mean C ( $\bar{C}$ all $)$

Mean $\mathrm{C}$ of natives ( $\bar{C}$ nat $)$

Cover-weighted Mean C (CW $\bar{C}$ all)

Cover-weighted Mean $\mathrm{C}$ of natives (CW $\bar{C}$ nat)

Floristic Quality Index for natives (FQI)

Floristic Quality Index for all species (FQlall)

Cover-weighted FQI for natives (CWFQI)

Cover-weighted FQI for all species (CWFQlall)

Adjusted FQI (AdjFQI)

Adjusted cover-weighted FQI (adjCWFQI)

\section{Formulas}

$$
N+A
$$

$N$

A

$\bar{C}=\sum_{j=1}^{N+A} C_{i} / N+A$

$\bar{C}=\sum_{j=1}^{N} C_{i} / N$

$\bar{C}=\sum_{j=1}^{N+A} p_{i} C_{i} / N+A$

$\bar{C}=\sum_{j=1}^{N} p_{i} C_{i} / N$

$F Q I=\bar{C} \sqrt{N}$

FQIall $=\bar{C} \sqrt{N+A}$

CWFQInat $=\left(\sum_{j=1}^{N} p_{j} C_{j}\right) \sqrt{N}$

$\mathrm{CWFQI}=\left(\sum_{j=1}^{N+A} p_{j} C_{j}\right) \sqrt{N+A}$

$\operatorname{adjF} Q I=(\bar{C} / 10)(\sqrt{N} / \sqrt{N+A}) * 100$

$\operatorname{adjCWFQI}=(C W \overline{C n a t} / 10)(\sqrt{N} / \sqrt{N+A}) * 100$

A Floristic Quality Index (FQI) was then calculated for each site assessed with a Level 3 using the following formula:

$$
F Q I=\bar{C} \sqrt{N}
$$

Where $\bar{C}$ is the mean $\mathrm{C}$-value and $N$ is the number of native species within the entire plot.

A FQI including both native and non-native species was calculated using the following formula:

$$
\text { FQIall }=\bar{C} \sqrt{N+A}
$$


The adjusted FQI score for each site was calculated for each site using the following formula:

$$
\operatorname{adjFQI}=(\bar{C} / 10)(\sqrt{N} / \sqrt{N+A}) * 100
$$

where $\bar{C}$ is the mean $\mathrm{C}$-value of native plant species, $N$ is the number of native species, and $A$ is the number of non-native species.

A cover-weighted index was calculated for each site using the following formula:

$$
\text { Cover-weighted FQI }=\left(\sum_{j=1}^{N+A} p_{j} C_{j}\right) \sqrt{N+A}
$$

Where $p$ stands for the relative average cover of a species and $C$ is the $\mathrm{C}$-value of each species $(j), \mathrm{N}$ is the number of native species, and $\mathrm{A}$ is the number of non-native species.

A cover weighted adjusted FQI was also calculated for each site using the following formula:

$$
\text { Adjusted cover-weighted } \mathrm{FQI}=(C W \overline{C n a t} / 10)(\sqrt{N} / \sqrt{N+A}) * 100
$$


Appendix I. Wetland Landscape Profiling 



\section{5th Code HUC Wetland Profiles}

Wetland Landscape Profiling of Palustrine Wetlands: Fifth-Code Hydrological Unit

\begin{tabular}{|c|c|c|c|c|c|c|c|c|}
\hline 5th Code HUC Name & HUC Number & Private & State & Federal & Tribal & Protected & Natural & Altered \\
\hline Headwaters Saint Mary River & 1001000201 & $0 \%$ & $0 \%$ & $100 \%$ & $0 \%$ & $100 \%$ & $100 \%$ & $0 \%$ \\
\hline Swiftcurrent Creek & 1001000202 & $0 \%$ & $0 \%$ & $60 \%$ & $40 \%$ & $100 \%$ & $85 \%$ & $15 \%$ \\
\hline Upper Saint Mary River & 1001000203 & $0 \%$ & $0 \%$ & $11 \%$ & $89 \%$ & $79 \%$ & $99 \%$ & $1 \%$ \\
\hline Lee Creek & 1001000204 & $0 \%$ & $0 \%$ & $4 \%$ & $96 \%$ & $85 \%$ & $100 \%$ & $0 \%$ \\
\hline Willow Creek & 1001000205 & $16 \%$ & $1 \%$ & $17 \%$ & $67 \%$ & $5 \%$ & $85 \%$ & $15 \%$ \\
\hline Upper Two Medicine River & 1003020101 & $0 \%$ & $0 \%$ & $28 \%$ & $72 \%$ & $87 \%$ & $99 \%$ & $1 \%$ \\
\hline Badger Creek & 1003020102 & $0 \%$ & $0 \%$ & $5 \%$ & $95 \%$ & $95 \%$ & $99 \%$ & $1 \%$ \\
\hline Middle Two Medicine River & 1003020103 & $0 \%$ & $0 \%$ & $0 \%$ & $100 \%$ & $82 \%$ & $98 \%$ & $2 \%$ \\
\hline Blacktail Creek & 1003020104 & $0 \%$ & $0 \%$ & $0 \%$ & $100 \%$ & $84 \%$ & $96 \%$ & $4 \%$ \\
\hline Dupuyer Creek & 1003020105 & $45 \%$ & $0 \%$ & $55 \%$ & $0 \%$ & $10 \%$ & $98 \%$ & $2 \%$ \\
\hline Birch Creek & 1003020106 & $40 \%$ & $0 \%$ & $10 \%$ & $49 \%$ & $68 \%$ & $97 \%$ & $3 \%$ \\
\hline Lower Two Medicine River & 1003020107 & $6 \%$ & $0 \%$ & $0 \%$ & $94 \%$ & $53 \%$ & $88 \%$ & $12 \%$ \\
\hline Upper Cut Bank Creek & 1003020201 & $0 \%$ & $0 \%$ & $3 \%$ & $97 \%$ & $86 \%$ & $100 \%$ & $0 \%$ \\
\hline Willow Creek & 1003020202 & $16 \%$ & $1 \%$ & $17 \%$ & $67 \%$ & $51 \%$ & $85 \%$ & $15 \%$ \\
\hline Middle Cut Bank Creek & 1003020203 & $0 \%$ & $0 \%$ & $0 \%$ & $100 \%$ & $64 \%$ & $93 \%$ & $7 \%$ \\
\hline Little Rock Coulee & 1003020204 & $0 \%$ & $0 \%$ & $0 \%$ & $100 \%$ & $70 \%$ & $86 \%$ & $14 \%$ \\
\hline Big Rock Coulee & 1003020205 & $52 \%$ & $4 \%$ & $0 \%$ & $44 \%$ & $25 \%$ & $89 \%$ & $11 \%$ \\
\hline Spring Creek & 1003020206 & $0 \%$ & $0 \%$ & $0 \%$ & $100 \%$ & $91 \%$ & $90 \%$ & $10 \%$ \\
\hline Lower Cut Bank Creek & 1003020207 & $25 \%$ & $1 \%$ & $0 \%$ & $74 \%$ & $71 \%$ & $97 \%$ & $3 \%$ \\
\hline Marias River-Schultz Coulee & 1003020301 & $100 \%$ & $0 \%$ & $0 \%$ & $0 \%$ & $9 \%$ & $90 \%$ & $10 \%$ \\
\hline Sunburst & 1003020302 & $96 \%$ & $3 \%$ & $1 \%$ & $0 \%$ & $49 \%$ & $94 \%$ & $6 \%$ \\
\hline Rocky Spring Coulee & 1003020303 & $94 \%$ & $2 \%$ & $5 \%$ & $0 \%$ & $100 \%$ & $91 \%$ & $9 \%$ \\
\hline Spring Coulee & 1003020304 & $99 \%$ & $1 \%$ & $0 \%$ & $0 \%$ & $1 \%$ & $95 \%$ & $5 \%$ \\
\hline Aloe Lake & 1003020305 & $97 \%$ & $3 \%$ & $0 \%$ & $0 \%$ & $100 \%$ & $94 \%$ & $6 \%$ \\
\hline Upper Dry Fork Marias River & 1003020306 & $64 \%$ & $0 \%$ & $36 \%$ & $0 \%$ & $13 \%$ & $45 \%$ & $55 \%$ \\
\hline Lower Dry Fork Marias River & 1003020307 & $98 \%$ & $2 \%$ & $0 \%$ & $0 \%$ & $5 \%$ & $66 \%$ & $34 \%$ \\
\hline Marias River-Pearson Coulee & 1003020308 & $88 \%$ & $4 \%$ & $8 \%$ & $0 \%$ & $12 \%$ & $82 \%$ & $18 \%$ \\
\hline Upper Pondera Coulee & 1003020309 & $99 \%$ & $1 \%$ & $0 \%$ & $0 \%$ & $2 \%$ & $74 \%$ & $26 \%$ \\
\hline South Pondera Coulee & 1003020310 & $96 \%$ & $4 \%$ & $0 \%$ & $0 \%$ & $12 \%$ & $62 \%$ & $38 \%$ \\
\hline Rocky Coulee & 1003020311 & $86 \%$ & $14 \%$ & $0 \%$ & $0 \%$ & $36 \%$ & $82 \%$ & $18 \%$ \\
\hline Powder Coulee & 1003020312 & $100 \%$ & $0 \%$ & $0 \%$ & $0 \%$ & $0 \%$ & $71 \%$ & $29 \%$ \\
\hline Lower Pondera Coulee & 1003020313 & $95 \%$ & $5 \%$ & $0 \%$ & $0 \%$ & $7 \%$ & $66 \%$ & $34 \%$ \\
\hline Basin Coulee & 1003020314 & $88 \%$ & $12 \%$ & $0 \%$ & $0 \%$ & $26 \%$ & $33 \%$ & $67 \%$ \\
\hline Dugout Coulee & 1003020315 & $91 \%$ & $9 \%$ & $0 \%$ & $0 \%$ & $9 \%$ & $22 \%$ & $78 \%$ \\
\hline Upper Cottonwood Creek & 1003020316 & $96 \%$ & $4 \%$ & $0 \%$ & $0 \%$ & $6 \%$ & $80 \%$ & $20 \%$ \\
\hline Middle Cottonwood Creek & 1003020317 & $92 \%$ & $8 \%$ & $0 \%$ & $0 \%$ & $9 \%$ & $68 \%$ & $32 \%$ \\
\hline Lower Cottonwood Creek & 1003020318 & $97 \%$ & $3 \%$ & $0 \%$ & $0 \%$ & $3 \%$ & $64 \%$ & $36 \%$ \\
\hline East Fork Black Coulee & 1003020319 & $98 \%$ & $2 \%$ & $0 \%$ & $0 \%$ & $2 \%$ & $93 \%$ & $7 \%$ \\
\hline Black Coulee & 1003020320 & $80 \%$ & $7 \%$ & $13 \%$ & $0 \%$ & $3 \%$ & $85 \%$ & $15 \%$ \\
\hline Marias River-Dead Indian Coulee & 1003020321 & $81 \%$ & $2 \%$ & $16 \%$ & $0 \%$ & $14 \%$ & $54 \%$ & $46 \%$ \\
\hline Marias River-Chip Creek & 1003020322 & $91 \%$ & $9 \%$ & $1 \%$ & $0 \%$ & $11 \%$ & $50 \%$ & $50 \%$ \\
\hline Black Coulee & 1003020401 & $80 \%$ & $7 \%$ & $13 \%$ & $0 \%$ & $5 \%$ & $85 \%$ & $15 \%$ \\
\hline Trail Creek & 1003020402 & $92 \%$ & $6 \%$ & $2 \%$ & $0 \%$ & $11 \%$ & $69 \%$ & $31 \%$ \\
\hline Upper Willow Creek & 1003020403 & $88 \%$ & $11 \%$ & $1 \%$ & $0 \%$ & $18 \%$ & $76 \%$ & $24 \%$ \\
\hline West Fork Willow Creek & 1003020404 & $97 \%$ & $3 \%$ & $0 \%$ & $0 \%$ & $7 \%$ & $73 \%$ & $27 \%$ \\
\hline Eagle Creek & 1003020405 & $82 \%$ & $18 \%$ & $0 \%$ & $0 \%$ & $22 \%$ & $77 \%$ & $23 \%$ \\
\hline Lower Willow Creek & 1003020406 & $91 \%$ & $1 \%$ & $8 \%$ & $0 \%$ & $3 \%$ & $54 \%$ & $46 \%$ \\
\hline Teton River-North Fork Teton Riv & er1003020501 & $60 \%$ & $0 \%$ & $40 \%$ & $0 \%$ & $86 \%$ & $100 \%$ & $0 \%$ \\
\hline Willow Creek & 1003020502 & $16 \%$ & $1 \%$ & $17 \%$ & $67 \%$ & $11 \%$ & $85 \%$ & $15 \%$ \\
\hline Deep Creek & 1003020503 & $53 \%$ & $3 \%$ & $44 \%$ & $0 \%$ & $13 \%$ & $78 \%$ & $22 \%$ \\
\hline
\end{tabular}


Wetland Landscape Profiling of Palustrine Wetlands: Fifth-Code Hydrological Unit

\begin{tabular}{|c|c|c|c|c|c|c|c|c|}
\hline 5th Code HUC Name & HUC Number & Private & State & Federal & Tribal & Protected & Natural & Altered \\
\hline Teton River-Choteau & 1003020504 & $45 \%$ & $52 \%$ & $3 \%$ & $0 \%$ & $67 \%$ & $66 \%$ & $34 \%$ \\
\hline Spring Coulee & 1003020505 & $99 \%$ & $1 \%$ & $0 \%$ & $0 \%$ & $23 \%$ & $95 \%$ & $5 \%$ \\
\hline Upper Muddy Creek & 1003020506 & $66 \%$ & $13 \%$ & $21 \%$ & $0 \%$ & $41 \%$ & $97 \%$ & $3 \%$ \\
\hline Middle Muddy Creek & 1003020507 & $56 \%$ & $0 \%$ & $44 \%$ & $0 \%$ & $80 \%$ & $97 \%$ & $3 \%$ \\
\hline Lower Muddy Creek & 1003020508 & $92 \%$ & $7 \%$ & $1 \%$ & $0 \%$ & $23 \%$ & $97 \%$ & $3 \%$ \\
\hline Teton River-Dutton & 1003020509 & $89 \%$ & $11 \%$ & $0 \%$ & $0 \%$ & $12 \%$ & $90 \%$ & $10 \%$ \\
\hline Teton River-Timber Coulee & 1003020510 & $92 \%$ & $7 \%$ & $1 \%$ & $0 \%$ & $31 \%$ & $79 \%$ & $21 \%$ \\
\hline Teton River-Weatherman Coulee & 1003020511 & $95 \%$ & $5 \%$ & $0 \%$ & $0 \%$ & $17 \%$ & $82 \%$ & $18 \%$ \\
\hline Teton River-Dry Fork Coulee & 1003020512 & $91 \%$ & $9 \%$ & $0 \%$ & $0 \%$ & $11 \%$ & $49 \%$ & $51 \%$ \\
\hline South Fork Milk River & 1005000101 & $0 \%$ & $0 \%$ & $0 \%$ & $100 \%$ & $79 \%$ & $99 \%$ & $1 \%$ \\
\hline North Fork Milk River & 1005000102 & $0 \%$ & $0 \%$ & $0 \%$ & $100 \%$ & $41 \%$ & $96 \%$ & $4 \%$ \\
\hline Milk River-Kennedy Coulee & 1005000103 & $0 \%$ & $0 \%$ & $0 \%$ & $100 \%$ & $68 \%$ & $93 \%$ & $7 \%$ \\
\hline Red River & 1005000201 & $90 \%$ & $9 \%$ & $0 \%$ & $0 \%$ & $18 \%$ & $87 \%$ & $13 \%$ \\
\hline Sweetgrass & 1005000202 & $100 \%$ & $0 \%$ & $0 \%$ & $0 \%$ & $0 \%$ & $89 \%$ & $11 \%$ \\
\hline Beaupre Coulee & 1005000203 & $97 \%$ & $2 \%$ & $1 \%$ & $0 \%$ & $36 \%$ & $87 \%$ & $13 \%$ \\
\hline Miners Coulee & 1005000204 & $84 \%$ & $4 \%$ & $12 \%$ & $0 \%$ & $11 \%$ & $78 \%$ & $22 \%$ \\
\hline Milk River-Spring Coulee & 1005000205 & $49 \%$ & $8 \%$ & $43 \%$ & $0 \%$ & $88 \%$ & $87 \%$ & $13 \%$ \\
\hline Ninemile Coulee & 1005000206 & $66 \%$ & $14 \%$ & $21 \%$ & $0 \%$ & $52 \%$ & $55 \%$ & $45 \%$ \\
\hline Dry Lake Coulee & 1005000207 & $81 \%$ & $5 \%$ & $14 \%$ & $0 \%$ & $44 \%$ & $93 \%$ & $7 \%$ \\
\hline Milk River-Fresno Reservoir & 1005000208 & $36 \%$ & $3 \%$ & $61 \%$ & $0 \%$ & $88 \%$ & $69 \%$ & $31 \%$ \\
\hline Wild Horse Lake & 1005000301 & $99 \%$ & $0 \%$ & $0 \%$ & $0 \%$ & $100 \%$ & $99 \%$ & $1 \%$ \\
\hline Beaver Creek & 1005000401 & $81 \%$ & $1 \%$ & $0 \%$ & $7 \%$ & $46 \%$ & $68 \%$ & $32 \%$ \\
\hline Little Boxelder Creek & 1005000402 & $99 \%$ & $1 \%$ & $0 \%$ & $0 \%$ & $1 \%$ & $83 \%$ & $17 \%$ \\
\hline Clear Creek & 1005000403 & $97 \%$ & $2 \%$ & $1 \%$ & $0 \%$ & $9 \%$ & $87 \%$ & $13 \%$ \\
\hline Milk River-Bullhook Creek & 1005000404 & $74 \%$ & $26 \%$ & $0 \%$ & $0 \%$ & $38 \%$ & $63 \%$ & $37 \%$ \\
\hline Redrock Coulee & 1005000405 & $93 \%$ & $4 \%$ & $3 \%$ & $0 \%$ & $19 \%$ & $78 \%$ & $22 \%$ \\
\hline Milk River-Fifteen Mile Creek & 1005000406 & $85 \%$ & $5 \%$ & $10 \%$ & $0 \%$ & $22 \%$ & $80 \%$ & $20 \%$ \\
\hline Box Elder Creek & 1005000407 & $81 \%$ & $19 \%$ & $0 \%$ & $0 \%$ & $27 \%$ & $59 \%$ & $41 \%$ \\
\hline Snake Creek & 1005000408 & $96 \%$ & $3 \%$ & $1 \%$ & $0 \%$ & $6 \%$ & $64 \%$ & $36 \%$ \\
\hline Thirtymile Creek & 1005000409 & $72 \%$ & $8 \%$ & $20 \%$ & $0 \%$ & $46 \%$ & $77 \%$ & $23 \%$ \\
\hline Wayne Creek & 1005000410 & $86 \%$ & $7 \%$ & $7 \%$ & $0 \%$ & $34 \%$ & $93 \%$ & $7 \%$ \\
\hline Savoy Creek & 1005000411 & $81 \%$ & $9 \%$ & $10 \%$ & $0 \%$ & $35 \%$ & $81 \%$ & $19 \%$ \\
\hline White Bear Creek & 1005000412 & $13 \%$ & $16 \%$ & $0 \%$ & $71 \%$ & $93 \%$ & $80 \%$ & $20 \%$ \\
\hline Milk River-Milk Creek & 1005000413 & $55 \%$ & $3 \%$ & $3 \%$ & $40 \%$ & $79 \%$ & $76 \%$ & $24 \%$ \\
\hline Dodson Creek & 1005000414 & $72 \%$ & $2 \%$ & $26 \%$ & $0 \%$ & $46 \%$ & $76 \%$ & $24 \%$ \\
\hline Milk River-Exeter Creek & 1005000415 & $80 \%$ & $3 \%$ & $17 \%$ & $0 \%$ & $45 \%$ & $84 \%$ & $16 \%$ \\
\hline Alkali Creek & 1005000416 & $78 \%$ & $6 \%$ & $16 \%$ & $0 \%$ & $100 \%$ & $81 \%$ & $19 \%$ \\
\hline Assiniboine Creek & 1005000417 & $88 \%$ & $6 \%$ & $5 \%$ & $0 \%$ & $15 \%$ & $82 \%$ & $18 \%$ \\
\hline Little Cottonwood Creek & 1005000418 & $63 \%$ & $7 \%$ & $29 \%$ & $2 \%$ & $69 \%$ & $89 \%$ & $11 \%$ \\
\hline Milk River-Hewitt Lake & 1005000419 & $75 \%$ & $3 \%$ & $22 \%$ & $1 \%$ & $86 \%$ & $76 \%$ & $24 \%$ \\
\hline Stinky Creek & 1005000420 & $76 \%$ & $8 \%$ & $16 \%$ & $0 \%$ & $31 \%$ & $62 \%$ & $38 \%$ \\
\hline Milk River-Snieder Coulee & 1005000421 & $96 \%$ & $3 \%$ & $1 \%$ & $0 \%$ & $77 \%$ & $94 \%$ & $6 \%$ \\
\hline Lonesome Lake & 1005000501 & $98 \%$ & $2 \%$ & $0 \%$ & $0 \%$ & $46 \%$ & $94 \%$ & $6 \%$ \\
\hline Big Sandy Creek-Gorman Creek & 1005000502 & $80 \%$ & $11 \%$ & $0 \%$ & $9 \%$ & $28 \%$ & $84 \%$ & $16 \%$ \\
\hline Big Sandy Creek-Boxelder Creek & 1005000503 & $65 \%$ & $7 \%$ & $9 \%$ & $18 \%$ & $68 \%$ & $73 \%$ & $27 \%$ \\
\hline Big Sandy Creek-Gravel Coulee & 1005000504 & $75 \%$ & $2 \%$ & $0 \%$ & $23 \%$ & $30 \%$ & $51 \%$ & $49 \%$ \\
\hline Upper Sage Creek & 1005000601 & $94 \%$ & $5 \%$ & $0 \%$ & $0 \%$ & $12 \%$ & $67 \%$ & $33 \%$ \\
\hline Little Sage Creek & 1005000602 & $88 \%$ & $12 \%$ & $0 \%$ & $0 \%$ & $17 \%$ & $78 \%$ & $22 \%$ \\
\hline O'Brien Coulee & 1005000603 & $93 \%$ & $7 \%$ & $0 \%$ & $0 \%$ & $10 \%$ & $73 \%$ & $27 \%$ \\
\hline England Coulee & 1005000604 & $98 \%$ & $2 \%$ & $0 \%$ & $0 \%$ & $8 \%$ & $92 \%$ & $8 \%$ \\
\hline Lower Sage Creek & 1005000605 & $92 \%$ & $8 \%$ & $0 \%$ & $0 \%$ & $18 \%$ & $63 \%$ & $37 \%$ \\
\hline Lodge Creek & 1005000701 & $85 \%$ & $8 \%$ & $7 \%$ & $0 \%$ & $24 \%$ & $56 \%$ & $44 \%$ \\
\hline
\end{tabular}


Wetland Landscape Profiling of Palustrine Wetlands: Fifth-Code Hydrological Unit

\begin{tabular}{|c|c|c|c|c|c|c|c|c|}
\hline 5th Code HUC Name & HUC Number & Private & State 1 & Federal & Tribal $\mathbf{P}$ & Protected & Natural & Altered \\
\hline East Fork Battle Creek & 1005000801 & $50 \%$ & $18 \%$ & $32 \%$ & $0 \%$ & $66 \%$ & $62 \%$ & $38 \%$ \\
\hline Battle Creek & 1005000802 & $81 \%$ & $4 \%$ & $15 \%$ & $0 \%$ & $100 \%$ & $40 \%$ & $60 \%$ \\
\hline South Fork Peoples Creek & 1005000901 & $10 \%$ & $0 \%$ & $0 \%$ & $90 \%$ & $97 \%$ & $77 \%$ & $23 \%$ \\
\hline Upper Peoples Creek & 1005000902 & $35 \%$ & $20 \%$ & $0 \%$ & $45 \%$ & $73 \%$ & $81 \%$ & $19 \%$ \\
\hline Lone Tree Coulee & 1005000903 & $7 \%$ & $0 \%$ & $0 \%$ & $93 \%$ & $92 \%$ & $58 \%$ & $42 \%$ \\
\hline Lower Peoples Creek & 1005000904 & $34 \%$ & $0 \%$ & $5 \%$ & $61 \%$ & $77 \%$ & $83 \%$ & $17 \%$ \\
\hline Murray Coulee & 1005001001 & $97 \%$ & $3 \%$ & $0 \%$ & $0 \%$ & $35 \%$ & $99 \%$ & $1 \%$ \\
\hline Buckley Creek & 1005001002 & $96 \%$ & $4 \%$ & $0 \%$ & $0 \%$ & $30 \%$ & $100 \%$ & $0 \%$ \\
\hline Woody Island Coulee & 1005001003 & $72 \%$ & $3 \%$ & $22 \%$ & $2 \%$ & $88 \%$ & $98 \%$ & $2 \%$ \\
\hline Black Coulee & 1005001004 & $80 \%$ & $7 \%$ & $13 \%$ & $0 \%$ & $26 \%$ & $85 \%$ & $15 \%$ \\
\hline Cottonwood Creek & 1005001005 & $65 \%$ & $5 \%$ & $29 \%$ & $0 \%$ & $43 \%$ & $85 \%$ & $15 \%$ \\
\hline East Fork Whitewater Creek & 1005001101 & $53 \%$ & $7 \%$ & $38 \%$ & $1 \%$ & $100 \%$ & $92 \%$ & $8 \%$ \\
\hline Whitewater Creek & 1005001102 & $59 \%$ & $3 \%$ & $38 \%$ & $1 \%$ & $92 \%$ & $94 \%$ & $6 \%$ \\
\hline Bear Creek & 1005001201 & $84 \%$ & $2 \%$ & $14 \%$ & $0 \%$ & $62 \%$ & $54 \%$ & $46 \%$ \\
\hline Buggy Creek & 1005001202 & $36 \%$ & $26 \%$ & $38 \%$ & $0 \%$ & $74 \%$ & $38 \%$ & $62 \%$ \\
\hline Antelope Creek & 1005001203 & $67 \%$ & $5 \%$ & $28 \%$ & $0 \%$ & $44 \%$ & $21 \%$ & $79 \%$ \\
\hline Milk River-Hinsdale & 1005001204 & $92 \%$ & $5 \%$ & $3 \%$ & $0 \%$ & $30 \%$ & $79 \%$ & $21 \%$ \\
\hline Brazil Creek & 1005001205 & $72 \%$ & $2 \%$ & $27 \%$ & $0 \%$ & $75 \%$ & $3 \%$ & $97 \%$ \\
\hline Cherry Creek & 1005001206 & $60 \%$ & $30 \%$ & $10 \%$ & $0 \%$ & $65 \%$ & $59 \%$ & $41 \%$ \\
\hline Lone Tree Creek & 1005001207 & $40 \%$ & $1 \%$ & $59 \%$ & $0 \%$ & $99 \%$ & $3 \%$ & $97 \%$ \\
\hline Little Beaver Creek & 1005001208 & $2 \%$ & $3 \%$ & $95 \%$ & $0 \%$ & $100 \%$ & $2 \%$ & $98 \%$ \\
\hline Willow Creek & 1005001209 & $16 \%$ & $1 \%$ & $17 \%$ & $67 \%$ & $11 \%$ & $85 \%$ & $15 \%$ \\
\hline Milk River-Glasgow & 1005001210 & $58 \%$ & $1 \%$ & $0 \%$ & $41 \%$ & $24 \%$ & $92 \%$ & $8 \%$ \\
\hline Frenchman Creek & 1005001301 & $82 \%$ & $8 \%$ & $9 \%$ & $0 \%$ & $27 \%$ & $78 \%$ & $22 \%$ \\
\hline Big Warm Creek & 1005001401 & $66 \%$ & $4 \%$ & $13 \%$ & $17 \%$ & $73 \%$ & $65 \%$ & $35 \%$ \\
\hline Upper Beaver Creek & 1005001402 & $65 \%$ & $5 \%$ & $29 \%$ & $1 \%$ & $44 \%$ & $71 \%$ & $29 \%$ \\
\hline Flat Creek & 1005001403 & $80 \%$ & $1 \%$ & $19 \%$ & $0 \%$ & $100 \%$ & $73 \%$ & $27 \%$ \\
\hline Middle Beaver Creek & 1005001404 & $83 \%$ & $3 \%$ & $14 \%$ & $0 \%$ & $56 \%$ & $73 \%$ & $27 \%$ \\
\hline Lake Bowdion & 1005001405 & $34 \%$ & $2 \%$ & $65 \%$ & $0 \%$ & $100 \%$ & $94 \%$ & $6 \%$ \\
\hline Larb Creek & 1005001406 & $60 \%$ & $2 \%$ & $38 \%$ & $0 \%$ & $50 \%$ & $36 \%$ & $64 \%$ \\
\hline Lower Beaver Creek & 1005001407 & $80 \%$ & $3 \%$ & $16 \%$ & $0 \%$ & $55 \%$ & $91 \%$ & $9 \%$ \\
\hline Upper Rock Creek & 1005001501 & $46 \%$ & $0 \%$ & $54 \%$ & $0 \%$ & $79 \%$ & $49 \%$ & $51 \%$ \\
\hline South Creek & 1005001502 & $33 \%$ & $1 \%$ & $66 \%$ & $0 \%$ & $100 \%$ & $17 \%$ & $83 \%$ \\
\hline Crow Creek & 1005001503 & $32 \%$ & $8 \%$ & $60 \%$ & $0 \%$ & $76 \%$ & $43 \%$ & $57 \%$ \\
\hline Big Snake Creek & 1005001504 & $70 \%$ & $1 \%$ & $28 \%$ & $0 \%$ & $36 \%$ & $47 \%$ & $53 \%$ \\
\hline Willow Creek & 1005001505 & $16 \%$ & $1 \%$ & $17 \%$ & $67 \%$ & $3 \%$ & $85 \%$ & $15 \%$ \\
\hline Lower Rock Creek & 1005001506 & $57 \%$ & $4 \%$ & $40 \%$ & $0 \%$ & $77 \%$ & $61 \%$ & $39 \%$ \\
\hline Snow Coulee & 1005001601 & $56 \%$ & $1 \%$ & $0 \%$ & $44 \%$ & $26 \%$ & $87 \%$ & $13 \%$ \\
\hline Middle Fork Porcupine Creek & 1005001602 & $82 \%$ & $2 \%$ & $1 \%$ & $15 \%$ & $14 \%$ & $68 \%$ & $32 \%$ \\
\hline West Fork Porcupine Creek & 1005001603 & $21 \%$ & $32 \%$ & $38 \%$ & $9 \%$ & $85 \%$ & $75 \%$ & $25 \%$ \\
\hline East Fork Porcupine Creek & 1005001604 & $0 \%$ & $0 \%$ & $0 \%$ & $100 \%$ & $27 \%$ & $84 \%$ & $16 \%$ \\
\hline Porcupine Creek & 1005001605 & $18 \%$ & $28 \%$ & $2 \%$ & $52 \%$ & $52 \%$ & $87 \%$ & $13 \%$ \\
\hline
\end{tabular}


The Milk, Marias, and Saint Mary Rivers Fifth-code Hydrologic Units

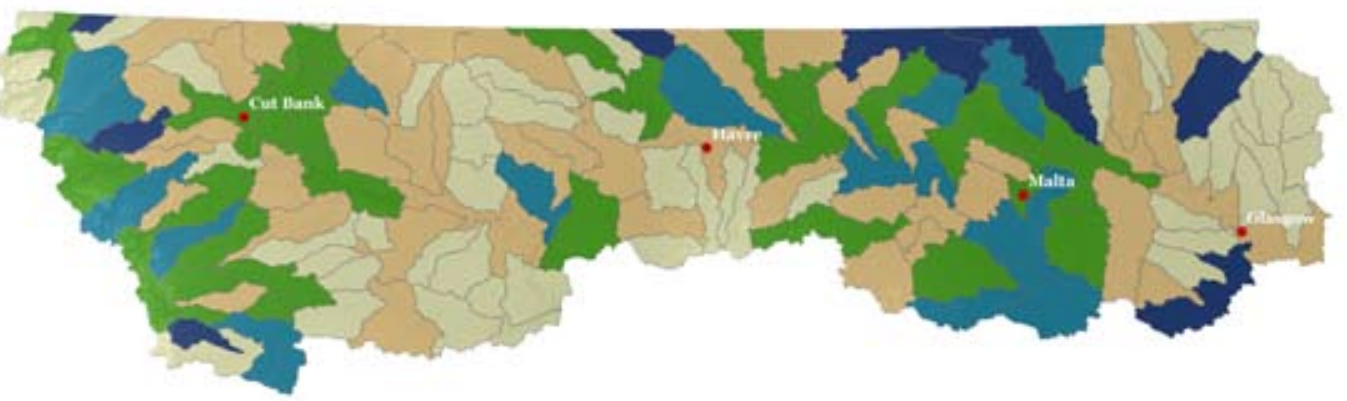

Acres of Mapped Wetlands NWIAcres

$104-1,024$

$1,025-2,329$

$2,330-4,191$

$4,192-7,201$

$7,202 \cdot 15,411$

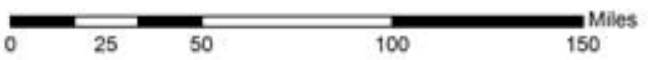

n-Streams

The Milk, Marias, and Saint Mary Rivers Fifth-code Hydrologic Units
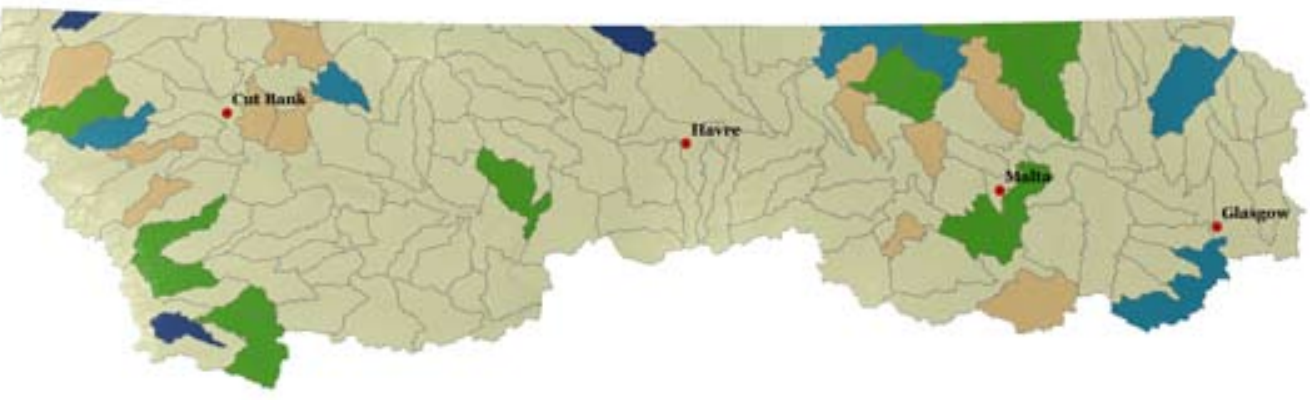

Wotland Density

Density

$\square 0.2$

$\square$

4.6

$7-14$

$15-47$

- Streams

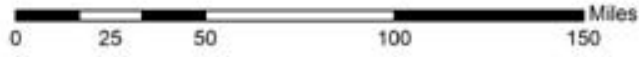

Appendix I - 4 
The Milk, Marias, and Saint Mary Rivers

Fifth-code Hydrologic Units

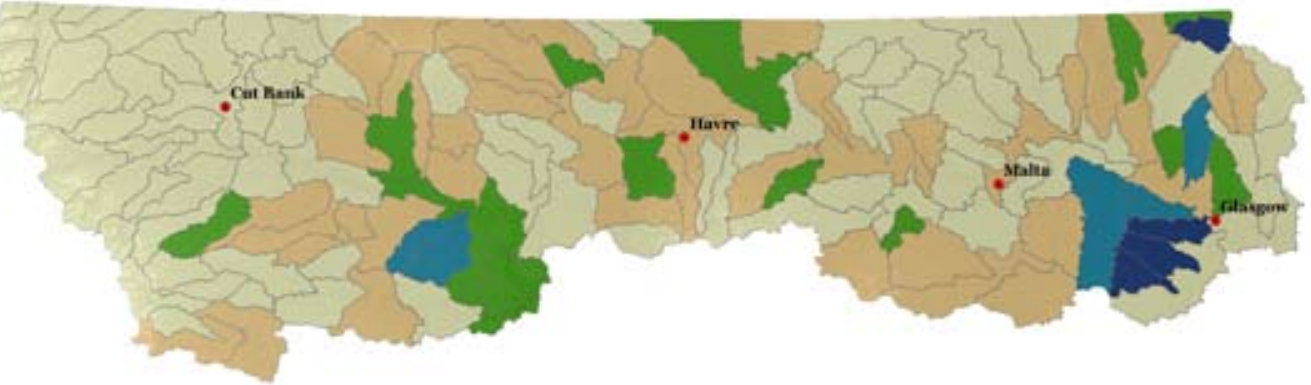

Percent of Altered Wetlands

$0 \%-20 \%$

$21 \%-40 \%$

$41 \%-60 \%$

$61 \% .80 \%$

D1\% - $100 \%$

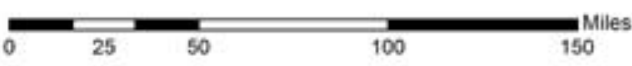

- Streams.

The Milk, Marias, and Saint Mary Rivers Fifth-code Hydrologic Units

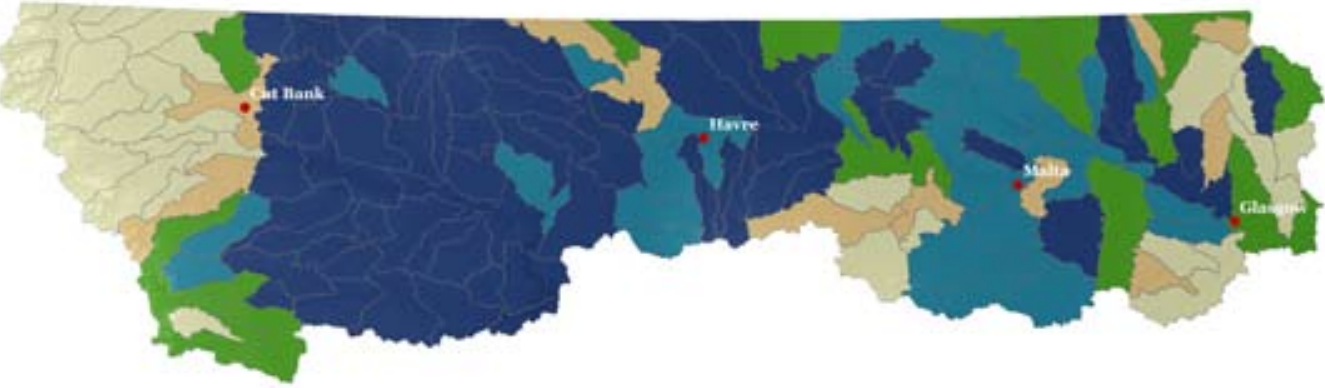

Percent of Mapped Wetlands on Private Land

$0 \%-20 \%$

$21 \%-40 \%$

$41 \%-60 \%$

$61 \%-80 \%$

$81 \%-100 \%$

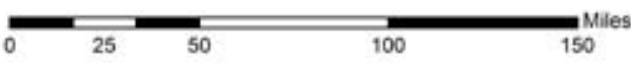




\section{6th Code HUC Wetland Profiles}

Wetland Landscape Profiling of Palustrine Wetlands: Sixth-Code Hydrological Unit

6th Code HUC Name

Headwaters Belly River

Upper Belly River

Headwaters Saint Mary River

Reynolds Creek

Red Eagle Creek

Saint Mary Lake

Swiftcurrent Lake

Boulder Creek

Swiftcurrent Creek

Duck Lake

Otatso Creek

Kennedy Creek

Lower Saint Mary Lakes

Saint Mary RiverInternational Border

West Fork Lee Creek

East Fork Lee Creek

Upper Willow Creek

Upper Lake Creek

Lower Lake Creek

Benton Lake

Huntley Coulee

Missouri River-Black Coulee

Missouri River-Bullhead Coulee

Missouri River-Bird Coulee

Missouri River-Fort Benton

Missouri River-Rowe Bench

Headwaters North Fork Sun River

Route Creek

Upper North Fork Sun River

Biggs Creek

Middle North Fork Sun River

Beaver Creek

Sun River-Alkali Flat

Sun River-Split Rock Lake

Sun River-Pishkun Reservoir

Sun River-Shed Coulee

School Section Coulee

Upper Big Coulee

North Fork Muddy Creek

Muddy Creek Headwaters

Power

Upper Muddy Creek

Third Bench

Spring Coulee

Two Medicine Lake

Two Medicine RiverMidvail Creek

Upper South Fork Two Medicine River

HUC Number Private State Federal Tribal Prot

\begin{tabular}{|c|c|c|c|c|c|c|c|}
\hline 100100010201 & $0 \%$ & $0 \%$ & $0 \%$ & $0 \%$ & $0 \%$ & $0 \%$ & $0 \%$ \\
\hline 100100010203 & $0 \%$ & $0 \%$ & $0 \%$ & $0 \%$ & $100 \%$ & $0 \%$ & $0 \%$ \\
\hline 100100020101 & $0 \%$ & $0 \%$ & $100 \%$ & $0 \%$ & $83 \%$ & $100 \%$ & $0 \%$ \\
\hline 100100020102 & $0 \%$ & $0 \%$ & $100 \%$ & $0 \%$ & $73 \%$ & $100 \%$ & $0 \%$ \\
\hline 100100020103 & $0 \%$ & $0 \%$ & $100 \%$ & $0 \%$ & $55 \%$ & $100 \%$ & $0 \%$ \\
\hline 100100020104 & $0 \%$ & $0 \%$ & $100 \%$ & $0 \%$ & $41 \%$ & $100 \%$ & $0 \%$ \\
\hline 100100020201 & $0 \%$ & $0 \%$ & $100 \%$ & $0 \%$ & $0 \%$ & $100 \%$ & $0 \%$ \\
\hline 100100020202 & $0 \%$ & $0 \%$ & $58 \%$ & $42 \%$ & $52 \%$ & $100 \%$ & $0 \%$ \\
\hline 100100020203 & $0 \%$ & $0 \%$ & $54 \%$ & $46 \%$ & $74 \%$ & $71 \%$ & $29 \%$ \\
\hline 100100020301 & $0 \%$ & $0 \%$ & $1 \%$ & $99 \%$ & $22 \%$ & $100 \%$ & $0 \%$ \\
\hline 100100020302 & $0 \%$ & $0 \%$ & $16 \%$ & $84 \%$ & $6 \%$ & $100 \%$ & $0 \%$ \\
\hline 100100020303 & $0 \%$ & $0 \%$ & $37 \%$ & $63 \%$ & $8 \%$ & $100 \%$ & $0 \%$ \\
\hline 100100020304 & $0 \%$ & $0 \%$ & $5 \%$ & $95 \%$ & $100 \%$ & $99 \%$ & $1 \%$ \\
\hline 100100020305 & $0 \%$ & $0 \%$ & $14 \%$ & $86 \%$ & $16 \%$ & $98 \%$ & $2 \%$ \\
\hline 100100020401 & $0 \%$ & $0 \%$ & $32 \%$ & $68 \%$ & $82 \%$ & $100 \%$ & $0 \%$ \\
\hline 100100020402 & $0 \%$ & $0 \%$ & $0 \%$ & $100 \%$ & $100 \%$ & $100 \%$ & $0 \%$ \\
\hline 100100020501 & $0 \%$ & $0 \%$ & $1 \%$ & $99 \%$ & $0 \%$ & $100 \%$ & $0 \%$ \\
\hline 100301021101 & $0 \%$ & $0 \%$ & $0 \%$ & $0 \%$ & $84 \%$ & $0 \%$ & $0 \%$ \\
\hline 100301021102 & $0 \%$ & $0 \%$ & $0 \%$ & $0 \%$ & $0 \%$ & $0 \%$ & $0 \%$ \\
\hline 100301021103 & $0 \%$ & $0 \%$ & $0 \%$ & $0 \%$ & $2 \%$ & $0 \%$ & $0 \%$ \\
\hline 100301021403 & $0 \%$ & $0 \%$ & $0 \%$ & $0 \%$ & $95 \%$ & $0 \%$ & $0 \%$ \\
\hline 100301021404 & $0 \%$ & $0 \%$ & $0 \%$ & $0 \%$ & $23 \%$ & $0 \%$ & $0 \%$ \\
\hline 100301021406 & $0 \%$ & $0 \%$ & $0 \%$ & $0 \%$ & $63 \%$ & $0 \%$ & $0 \%$ \\
\hline 100301021601 & $0 \%$ & $0 \%$ & $0 \%$ & $0 \%$ & $47 \%$ & $0 \%$ & $0 \%$ \\
\hline 100301021602 & $0 \%$ & $0 \%$ & $0 \%$ & $0 \%$ & $42 \%$ & $0 \%$ & $0 \%$ \\
\hline 100301021605 & $0 \%$ & $0 \%$ & $0 \%$ & $0 \%$ & $49 \%$ & $0 \%$ & $0 \%$ \\
\hline 100301040103 & $0 \%$ & $0 \%$ & $0 \%$ & $0 \%$ & $39 \%$ & $0 \%$ & $0 \%$ \\
\hline 100301040104 & $0 \%$ & $0 \%$ & $0 \%$ & $0 \%$ & $56 \%$ & $0 \%$ & $0 \%$ \\
\hline 100301040107 & $0 \%$ & $0 \%$ & $0 \%$ & $0 \%$ & $2 \%$ & $0 \%$ & $0 \%$ \\
\hline 100301040108 & $0 \%$ & $0 \%$ & $0 \%$ & $0 \%$ & $65 \%$ & $0 \%$ & $0 \%$ \\
\hline 100301040110 & $0 \%$ & $0 \%$ & $0 \%$ & $0 \%$ & $98 \%$ & $0 \%$ & $0 \%$ \\
\hline 100301040403 & $0 \%$ & $0 \%$ & $0 \%$ & $0 \%$ & $5 \%$ & $0 \%$ & $0 \%$ \\
\hline 100301040404 & $0 \%$ & $0 \%$ & $0 \%$ & $0 \%$ & $98 \%$ & $0 \%$ & $0 \%$ \\
\hline 100301040405 & $0 \%$ & $0 \%$ & $0 \%$ & $0 \%$ & $97 \%$ & $0 \%$ & $0 \%$ \\
\hline 100301040406 & $0 \%$ & $0 \%$ & $0 \%$ & $0 \%$ & $100 \%$ & $0 \%$ & $0 \%$ \\
\hline 100301040601 & $0 \%$ & $0 \%$ & $0 \%$ & $0 \%$ & $4 \%$ & $0 \%$ & $0 \%$ \\
\hline 100301040701 & $0 \%$ & $0 \%$ & $0 \%$ & $0 \%$ & $42 \%$ & $0 \%$ & $0 \%$ \\
\hline 100301040705 & $0 \%$ & $0 \%$ & $0 \%$ & $0 \%$ & $37 \%$ & $0 \%$ & $0 \%$ \\
\hline 100301040801 & $0 \%$ & $0 \%$ & $0 \%$ & $0 \%$ & $11 \%$ & $0 \%$ & $0 \%$ \\
\hline 100301040802 & $0 \%$ & $0 \%$ & $0 \%$ & $0 \%$ & $70 \%$ & $0 \%$ & $0 \%$ \\
\hline 100301040803 & $0 \%$ & $0 \%$ & $0 \%$ & $0 \%$ & $8 \%$ & $0 \%$ & $0 \%$ \\
\hline 100301040804 & $0 \%$ & $0 \%$ & $0 \%$ & $0 \%$ & $7 \%$ & $0 \%$ & $0 \%$ \\
\hline 100301040805 & $0 \%$ & $0 \%$ & $0 \%$ & $0 \%$ & $95 \%$ & $0 \%$ & $0 \%$ \\
\hline 100301040806 & $0 \%$ & $0 \%$ & $0 \%$ & $0 \%$ & $100 \%$ & $0 \%$ & $0 \%$ \\
\hline 100302010101 & $0 \%$ & $0 \%$ & $92 \%$ & $8 \%$ & $22 \%$ & $92 \%$ & $8 \%$ \\
\hline 100302010102 & $0 \%$ & $0 \%$ & $62 \%$ & $38 \%$ & $59 \%$ & $98 \%$ & $2 \%$ \\
\hline 100302010103 & $0 \%$ & $0 \%$ & $100 \%$ & $0 \%$ & $7 \%$ & $100 \%$ & $0 \%$ \\
\hline
\end{tabular}


Wetland Landscape Profiling of Palustrine Wetlands: Sixth-Code Hydrological Unit 6th Code HUC Name HUC Number Private State Federal Tribal Protected Natural Altered

Lower South Fork Two Medicine River

Little Badger Creek

Two Medicine River-Elk Creek

Headwaters Badger Creek

Badger Creek-Lonesome Creek

Badger Creek-Mitten Lake

Badger Creek-Hay Coulee

Whitetail Creek

Lower Badger Creek

Two Medicine River-

Big Nose Coulee

Two Medicine River-Hagan Flat

Upper Blacktail Creek

Lower Blacktail Creek

Upper Dupuyer Creek

Sheep Creek

Middle Dupuyer Creek

Lower Dupuyer Creek

Middle Fork Birch Creek

South Fork Birch Creek

North Fork Birch Creek

Upper Birch Creek

Cartwright Coulee

Middle Birch Creek

Rocky Ridge Coulee

Lower Birch Creek

Kipps Coulee

Two Medicine River-

Shields Crossing

North Fork Cut Bank Creek

Upper Cut Bank Creek-

Running Crane Lake

Greasewood Creek

Upper Cut Bank Creek-Sharp Lake

Depot Creek

Upper Willow Creek

Middle Willow Creek

Lower Willow Creek

Trail Coulee

Cut Bank John Coulee

Cobell Coulee

Powell Coulee

Middle Cut Bank Creek-Ford

Upper Little Rock Coulee

Middle Little Rock Coulee

South Fork Little Rock Coulee

Lower Little Rock Coulee

East Fork Big Rock Coulee

Headwaters Big Rock Coulee

Upper Big Rock Coulee

Middle Big Rock Coulee

100302010104

100302010105

100302010106

100302010201

100302010202

100302010203

100302010204

100302010205

100302010206

100302010301

100302010302

100302010401

100302010402

100302010501

100302010502

100302010503

100302010504

100302010601

100302010602

100302010603

100302010604

100302010605

100302010606

100302010607

100302010608

100302010701

100302010702

100302020101

100302020102

100302020103

100302020104

100302020201

100302020202

100302020203

100302020204

100302020301

100302020302

100302020303

100302020304

100302020305

100302020401

100302020402

100302020403

100302020404

100302020501

100302020502

100302020503

100302020504

$0 \% \quad 0 \%$

$0 \%$

$0 \%$

$0 \%$

$0 \%$

$0 \%$

$0 \%$

$0 \%$

$0 \%$

$0 \%$

$0 \%$

$0 \%$

$0 \%$
$50 \%$

$50 \%$

$28 \% \quad 0 \%$

$33 \% \quad 0 \%$

$98 \% \quad 2 \%$

$0 \% \quad 0 \%$

$0 \%$

$0 \%$

$0 \% \quad 0 \%$

$8 \% \quad 0 \%$

$97 \% \quad 3 \%$

$49 \% \quad 0 \%$

$0 \% \quad 0 \%$

$59 \% \quad 0 \%$

$0 \%$

$6 \%$

$0 \%$

$0 \%$

$0 \%$

$0 \%$

$0 \%$

$0 \%$

$0 \% \quad 0 \% \quad 0 \%$

$0 \%$

$0 \%$

$0 \%$

$0 \%$

$0 \%$

$0 \%$

$0 \%$

$0 \%$

$0 \%$

$0 \%$

$0 \%$

$0 \%$

$0 \%$

$0 \%$

$0 \%$

$0 \%$

$0 \%$

$0 \%$

$0 \%$

$0 \%$

$0 \%$

$0 \%$

$0 \%$

$0 \%$

$0 \% \quad 0 \%$

$0 \% \quad 0 \%$

$46 \% \quad 2 \%$

$0 \% \quad 0 \%$

$5 \% \quad 0 \%$

$89 \% \quad 10 \%$

$0 \%$

$0 \%$

$0 \%$

$0 \%$

$0 \%$

$0 \%$

$1 \%$

$0 \%$

$0 \%$

$0 \%$

$0 \%$

$0 \%$

$0 \%$

$0 \%$

$0 \%$

$0 \%$

$0 \%$

$0 \%$

$0 \%$

$0 \%$

$0 \%$

$0 \%$

$0 \%$

$0 \%$

$0 \%$
$55 \%$

$45 \%$

$100 \%$

$100 \% \quad 0 \%$

\section{$2 \%$}

$0 \%$

$100 \%$

$100 \%$

$0 \%$

$0 \%$

$50 \%$

$72 \%$

$67 \%$

$0 \%$

$100 \%$

$100 \%$

$100 \%$

$50 \%$

$0 \%$

$22 \%$

$1 \%$

$0 \%$

$23 \%$

$0 \%$

$0 \%$

$98 \% \quad 100 \% \quad 100 \% \quad 0 \%$

$100 \% \quad 0 \% \quad 99 \% \quad 1 \%$

$0 \% \quad 79 \% \quad 100 \% \quad 0 \%$

$0 \% \quad 63 \% \quad 100 \% \quad 0 \%$

$100 \% \quad 43 \% \quad 98 \% \quad 2 \%$

$100 \% \quad 15 \% \quad 99 \% \quad 1 \%$

$100 \% \quad 11 \% \quad 100 \% \quad 0 \%$

$100 \% \quad 52 \% \quad 99 \% \quad 1 \%$

$100 \% \quad 50 \% \quad 99 \% \quad 1 \%$

$\begin{array}{llll}100 \% & 49 \% & 97 \% & 3 \% \\ 100 \% & 47 \% & 99 \% & 1 \% \\ 100 \% & 11 \% & 88 \% & 12 \% \\ 0 \% & 6 \% & 99 \% & 1 \% \\ 0 \% & 10 \% & 99 \% & 1 \% \\ 0 \% & 100 \% & 97 \% & 3 \% \\ 0 \% & 46 \% & 96 \% & 4 \% \\ 0 \% & 6 \% & 100 \% & 0 \% \\ 0 \% & 95 \% & 100 \% & 0 \% \\ 0 \% & 100 \% & 100 \% & 0 \% \\ 43 \% & 100 \% & 99 \% & 1 \% \\ 0 \% & 100 \% & 90 \% & 10 \% \\ 50 \% & 100 \% & 99 \% & 1 \% \\ 100 \% & 0 \% & 96 \% & 4 \% \\ 41 \% & 18 \% & 97 \% & 3 \% \\ 100 \% & 45 \% & 62 \% & 38 \% \\ 94 \% & 45 \% & 90 \% & 10 \%\end{array}$

$78 \% \quad 0 \% \quad 100 \% \quad 0 \%$

$99 \% \quad 66 \% \quad 100 \% \quad 0 \%$

$100 \% \quad 96 \% \quad 99 \% \quad 1 \%$

$100 \% \quad 41 \% \quad 99 \% \quad 1 \%$

$77 \% \quad 9 \% \quad 88 \% \quad 12 \%$

$100 \% \quad 29 \% \quad 99 \% \quad 1 \%$

$100 \% \quad 0 \% \quad 99 \% \quad 1 \%$

$100 \% \quad 2 \% \quad 99 \% \quad 1 \%$

$100 \% \quad 1 \% \quad 50 \% \quad 50 \%$

$100 \% \quad 0 \% \quad 69 \% \quad 31 \%$

$100 \% \quad 7 \% \quad 48 \% \quad 52 \%$

$100 \% \quad 0 \% \quad 77 \% \quad 23 \%$

$100 \% \quad 24 \% \quad 99 \% \quad 1 \%$

$100 \% \quad 36 \% \quad 82 \% \quad 18 \%$

$100 \% \quad 100 \% \quad 76 \% \quad 24 \%$

$100 \% \quad 0 \% \quad 93 \% \quad 7 \%$

$100 \% \quad 0 \% \quad 68 \% \quad 32 \%$

$52 \% \quad 60 \% \quad 83 \% \quad 17 \%$

$100 \% \quad 29 \% \quad 77 \% \quad 23 \%$

$95 \% \quad 0 \% \quad 84 \% \quad 16 \%$

$1 \% \quad 41 \% \quad 99 \% \quad 1 \%$ 
Wetland Landscape Profiling of Palustrine Wetlands: Sixth-Code Hydrological Unit

\section{6th Code HUC Name}

Lower Big Rock Coulee

Guardipee Lake

Mission Lake

Upper Spring Creek

Lower Spring Creek

Gillam Coulee

Cut Bank Creek-Wasteway Coulee

Snake Coulee

Old Maids Coulee

Cut Bank Creek-Hope Lake

Cut Bank Creek

Marias River-Appott Coulee

Bullhead Creek

Schultz Coulee

Marias River-Interfluvial

East Fork Red River

Rim Rock Colony

Gravel Pit

Sunburst

Willshaw Flats

Kevin

Healy Coulee

Upper Rocky Spring Coulee

Lower Rocky Spring Coulee

Sand Coulee

Upper Spring Coulee

Lower Spring Coulee

Aloe Lake

Mead Coulee

South Fork Dry Fork Marias River 100302030601

Middle Fork Dry Fork Marias River100302030602

Lake Frances

100302030603

North Fork Dry Fork Marias River

Lone Man Coulee

Dry Fork Marias River-

New Miami Colony

Spring Creek

Dry Fork Marias River-Williams

Big Flat Coulee

Little Flat Coulee

Dry Fork Marias River-Latz Lake

Dry Fork Marias River-Fowler

Pearson Coulee

Marias River-Shelby

Marias River-Williamson Park

Marias River-F Bridge

Marias River-Hoffman Coulee

Upper Upper Pondera Coulee

Middle Upper Pondera Coulee

Favot Coulee

Lower Upper Pondera Coulee

Upper South Pondera Coulee

100302020601

100302020602

100302020603

100302020604

100302020701

100302020703

100302020704

100302020705

100302020706

100302030101

100302030102

100302030103

100302030104

100302030201

100302030202

100302030203

100302030204

100302030205

100302030301

100302030302

100302030303

100302030304

100302030401

100302030402

100302030403

100302030501

100302030502

100302030605

100302030606

100302030701

100302030702

100302030703

100302030704

100302030705

100302030706

100302030801

100302030802

100302030803

100302030804

100302030805

100302030901

100302030902

100302030904

100302031001

HUC Number Private State Federal Tribal Protected Natural Altered

100302020505

$72 \% \quad 0 \%$

$97 \% \quad 3 \% \quad 0 \%$

100302030903

$40 \% \quad 0 \%$

$0 \%$

$\begin{array}{lll}0 \% & 0 \% & 0 \% \\ 0 \% & 0 \% & 0 \%\end{array}$

$0 \% \quad 0 \% \quad 0 \%$

$0 \% \quad 0 \% \quad 0 \%$

$0 \% \quad 0 \% \quad 0 \%$

$98 \% \quad 2 \%$

$97 \% \quad 3 \%$

$6 \% \quad 0 \%$

$32 \% \quad 1 \%$

$100 \% \quad 0 \%$

$100 \% \quad 0 \%$

$99 \% \quad 1 \%$

$99 \% \quad 1 \%$

$98 \% \quad 2 \%$

$91 \% \quad 8 \%$

$100 \% \quad 0 \%$

$99 \% \quad 0 \%$

$96 \% \quad 3 \%$

$91 \% \quad 4 \%$

$99 \% \quad 1 \%$

$94 \% \quad 1 \%$

$96 \% \quad 0 \%$

$98 \% \quad 2 \%$

$98 \% \quad 2 \%$

$94 \% \quad 6 \%$

$95 \% \quad 5 \%$

$99 \% \quad 1 \%$

$7 \% \quad 0 \%$

$97 \% \quad 3 \%$

$99 \% \quad 1 \%$

$100 \% \quad 0 \%$

$76 \% \quad 24 \%$

$0 \%$

$0 \%$

$0 \%$

$0 \%$

$0 \%$

$0 \%$

$0 \%$

$0 \%$

$0 \%$

$0 \%$

$0 \%$

$1 \%$

$1 \%$

$5 \%$

$0 \%$

$5 \%$

$4 \%$

$0 \%$

$0 \%$

$0 \%$

$0 \%$

$0 \%$

$28 \%$

$93 \%$

$0 \%$

$0 \%$

$0 \%$

$0 \%$

$60 \%$

$100 \% \quad 80 \%$

$100 \% \quad 54 \%$

$100 \% \quad 17 \%$

$0 \% \quad 55 \%$

$0 \% \quad 100 \%$

$94 \% \quad 49 \%$

$67 \% \quad 27 \%$

$0 \% \quad 5 \%$

$0 \% \quad 56 \%$

$0 \% \quad 10 \%$

$0 \% \quad 53 \%$

$0 \% \quad 63 \%$

$0 \% \quad 7 \%$

$0 \%$

$0 \%$

$0 \%$

$0 \%$

$0 \%$

$0 \%$

$0 \%$

$0 \%$

$0 \%$

$0 \%$

$0 \%$

$0 \%$

$0 \%$

$0 \%$

$0 \%$

$100 \% \quad 0 \% \quad 0 \%$

$93 \% \quad 7 \% \quad 0 \%$

$100 \% \quad 0 \% \quad 0 \%$

$100 \% \quad 0 \% \quad 0 \%$

$98 \% \quad 2 \% \quad 0 \%$

$97 \% \quad 3 \% \quad 0 \%$

$97 \% \quad 0 \% \quad 2 \%$

$94 \% \quad 6 \% \quad 0 \%$

$77 \% \quad 4 \% \quad 19 \%$

$90 \% \quad 5 \%$

$99 \% \quad 1 \%$

$98 \% \quad 2 \%$

$99 \% \quad 1 \%$

$99 \% \quad 1 \%$

$94 \% \quad 6 \%$

$5 \%$

$0 \%$

$0 \%$

$0 \%$

$0 \%$

$0 \%$
$100 \% \quad 14 \%$

$100 \% \quad 7 \%$

$0 \% \quad 73 \%$

$0 \% \quad 76 \%$

$0 \%$

\begin{tabular}{ll}
$80 \%$ & $20 \%$ \\
$97 \%$ & $3 \%$ \\
$58 \%$ & $42 \%$ \\
$99 \%$ & $1 \%$ \\
$97 \%$ & $3 \%$ \\
$61 \%$ & $39 \%$ \\
$99 \%$ & $1 \%$ \\
$100 \%$ & $0 \%$ \\
$83 \%$ & $17 \%$ \\
$90 \%$ & $10 \%$ \\
$80 \%$ & $20 \%$ \\
$97 \%$ & $3 \%$ \\
$95 \%$ & $5 \%$ \\
$85 \%$ & $15 \%$ \\
$78 \%$ & $22 \%$ \\
$77 \%$ & $23 \%$ \\
$93 \%$ & $7 \%$ \\
$93 \%$ & $7 \%$ \\
$95 \%$ & $5 \%$ \\
$96 \%$ & $4 \%$ \\
$92 \%$ & $8 \%$ \\
$89 \%$ & $11 \%$ \\
$71 \%$ & $29 \%$ \\
$93 \%$ & $7 \%$ \\
$81 \%$ & $19 \%$ \\
$93 \%$ & $7 \%$ \\
$87 \%$ & $13 \%$ \\
$94 \%$ & $6 \%$ \\
$95 \%$ & $5 \%$ \\
$23 \%$ & $77 \%$ \\
$94 \%$ & $6 \%$ \\
$77 \%$ & $23 \%$ \\
$70 \%$ & $30 \%$ \\
$9 \%$ & $91 \%$ \\
$35 \%$ & $65 \%$ \\
& \\
$71 \%$ & $29 \%$ \\
\hline 0
\end{tabular}

$71 \% \quad 29 \%$

$70 \% \quad 30 \%$

$82 \% \quad 18 \%$

$64 \% \quad 36 \%$

$59 \% \quad 41 \%$

$61 \% \quad 39 \%$

$87 \% \quad 13 \%$

$70 \% \quad 30 \%$

$86 \% \quad 14 \%$

$74 \% \quad 26 \%$

$90 \% \quad 10 \%$

$79 \% \quad 21 \%$

$70 \% \quad 30 \%$

$69 \% \quad 31 \%$

$\begin{array}{llll}0 \% & 15 \% & 75 \% & 25 \% \\ 0 \% & 0 \% & 69 \% & 31 \%\end{array}$ 
Wetland Landscape Profiling of Palustrine Wetlands: Sixth-Code Hydrological Unit

6th Code HUC Name

Lower South Pondera Coulee

Upper Rocky Coulee

Lower Rocky Coulee

Upper Powder River

Lower Powder River

Flat Coulee

Dead Indian Coulee

Upper Lower Pondera Coulee

Middle Lower Pondera Coulee

Timber Coulee

Lower Lower Pondera Coulee

Upper Basin Coulee

Middle Basin Coulee

Lower Basin Coulee

North Fork Dugout Coulee

Upper Dugout Coulee

East Fork Dugout Coulee

Lower Dugout Coulee

Corral Creek

Government Creek

Horse Creek

Upper Cottonwood Creek

Cottonwood Creek

Tiber Coulee

Cottonwood Creek-Chester

Cox Coulee

Twelvemile Coulee

Sixmile Coulee

Cottonwood Creek-Larson Coulee 100302031804

Headwaters East Fork Black Coulee100302031901

East Fork Black Coulee-Joplin

100302031902

East Fork Black Coulee-Inverness

100302031904

100302031903

100302031904

East Fork Black Coulee-Ean School100302031905

Lower East Fork Black Coulee

Headwaters Black Coulee

Upper Black Coulee

Rocky Coulee

Middle Black Coulee

Flat Coulee

Lower Black Coulee

Marias River-Bootlegger Trail

Marias River-Smith Coulee

Marias River-Spring Coulee

Hay Coulee

Marias River-Horse Coulee

Dead Indian Coulee

Marias River-Eightmile Coulee

Marias River-Fourmile Coulee

Sheep Coulee

Lone Tree Coulee

Dry Fork Coulee West

100302031601

00302031603

100302031604

100302031703

100302031906

100302032001

100302032002

100302032003

100302032004

100302032005

100302032006

100302032102

100302032103

100302032104

100302032105

100302032106

00302032107

100302032108

100302032201

100302032202

100302032203
HUC Number Private State Federal Tribal Protected Natural Altered

$\begin{array}{llll} & & \end{array}$

$99 \% \quad 1 \% \quad 0 \%$

$100302031201 \quad 100 \% \quad 0 \% \quad 0 \%$

$100302031202 \quad 100 \% \quad 0 \% \quad 0 \%$

$100302031301 \quad 96 \% \quad 4 \% \quad 0 \%$

$100302031302 \quad 98 \% \quad 2 \% \quad 0 \%$

$100302031303 \quad 83 \% \quad 17 \% \quad 0 \%$

$100302031304 \quad 99 \% \quad 1 \% \quad 0 \%$

$100302031305 \quad 100 \% \quad 0 \% \quad 0 \%$

$100302031306 \quad 81 \% \quad 19 \% \quad 0 \%$

$100302031401 \quad 86 \% \quad 14 \% \quad 0 \%$

$100302031402 \quad 97 \% \quad 3 \% \quad 0 \%$

$100302031403 \quad 77 \% \quad 23 \% \quad 0 \%$

$100302031501 \quad 99 \% \quad 1 \% \quad 0 \%$

$100302031502 \quad 95 \% \quad 5 \% \quad 0 \%$

$100302031503 \quad 89 \% \quad 11 \% \quad 0 \%$

$100302031504 \quad 81 \% \quad 19 \% \quad 0 \%$

100302031602

100302031702

100302031801

100302031802

$100 \% \quad 0 \% \quad 0 \%$

$88 \% \quad 12 \% \quad 0 \%$

$96 \% \quad 4 \% \quad 0 \%$

$99 \% \quad 1 \% \quad 0 \%$

$95 \% \quad 5 \% \quad 0 \%$

$86 \% \quad 14 \% \quad 0 \%$

$96 \% \quad 4 \% \quad 0 \%$

$96 \% \quad 4 \% \quad 0 \%$

$100 \% \quad 0 \% \quad 0 \%$

$98 \% \quad 2 \% \quad 0 \%$

$94 \% \quad 6 \% \quad 0 \%$

$98 \% \quad 2 \% \quad 0 \%$

$100 \% \quad 0 \% \quad 0 \%$

$94 \% \quad 6 \% \quad 0 \%$

$100 \% \quad 0 \% \quad 0 \%$

$100 \% \quad 0 \% \quad 0 \%$

$99 \% \quad 1 \% \quad 0 \%$

$85 \% \quad 15 \% \quad 0 \%$

$99 \% \quad 1 \% \quad 0 \%$

$100 \% \quad 0 \% \quad 0 \%$

$97 \% \quad 3 \% \quad 0 \%$

$96 \% \quad 4 \% \quad 0 \%$

$95 \% \quad 5 \% \quad 0 \%$

$92 \% \quad 1 \%$

$15 \% \quad 2 \%$

$50 \% \quad 3 \%$

$83 \%$

$91 \%$

$0 \%$

$47 \%$

$87 \% \quad 10 \%$

$8 \%$

$99 \%$

$1 \% \quad 0 \%$

$0 \%$

$0 \%$

$0 \%$

$0 \%$

$0 \%$

$0 \%$

$0 \%$

$0 \%$

$0 \%$

$0 \%$

$0 \%$

$0 \%$

$0 \%$

$0 \%$

$0 \%$

$0 \%$

$0 \%$

$0 \%$

$0 \%$

$0 \%$

$0 \%$

$0 \%$

$0 \%$

$0 \%$

$0 \%$

$0 \%$

$0 \%$

$0 \%$

$0 \%$

$0 \%$

$0 \%$

$0 \%$

$0 \%$

$0 \%$

$0 \%$

$0 \%$

$0 \%$

$0 \%$

$0 \%$

$0 \%$

$0 \%$

$0 \%$

$0 \%$

$0 \%$

$0 \%$

$0 \%$

$0 \%$

$0 \%$

$0 \%$

$0 \%$

$0 \%$

$0 \%$

$0 \%$

$29 \%$

$50 \%$

$61 \% \quad 39 \%$

$5 \% \quad 92 \% \quad 8 \%$

$4 \% \quad 70 \% \quad 30 \%$

$15 \% \quad 75 \% \quad 25 \%$

$7 \% \quad 47 \% \quad 53 \%$

$100 \% \quad 46 \% \quad 54 \%$

$27 \% \quad 74 \% \quad 26 \%$

$68 \% \quad 87 \% \quad 13 \%$

$100 \% \quad 81 \% \quad 19 \%$

$10 \% \quad 16 \% \quad 84 \%$

$20 \% \quad 38 \% \quad 62 \%$

$16 \% \quad 43 \% \quad 57 \%$

$13 \% \quad 11 \% \quad 89 \%$

$7 \% \quad 15 \% \quad 85 \%$

$13 \% \quad 38 \% \quad 62 \%$

$0 \% \quad 14 \% \quad 86 \%$

$1 \% \quad 11 \% \quad 89 \%$

$31 \% \quad 86 \% \quad 14 \%$

$12 \% \quad 87 \% \quad 13 \%$

$100 \% \quad 72 \% \quad 28 \%$

$44 \% \quad 77 \% \quad 23 \%$

$21 \% \quad 65 \% \quad 35 \%$

$15 \% \quad 73 \% \quad 27 \%$

$76 \% \quad 65 \% \quad 35 \%$

$59 \% \quad 53 \% \quad 47 \%$

$49 \% \quad 29 \% \quad 71 \%$

$88 \% \quad 87 \% \quad 13 \%$

$40 \% \quad 26 \% \quad 74 \%$

$9 \% \quad 96 \% \quad 4 \%$

$27 \% \quad 96 \% \quad 4 \%$

$50 \% \quad 82 \% \quad 18 \%$

$35 \%$

$67 \%$

$76 \%$

$56 \%$

$47 \%$

$7 \%$

$40 \%$

$27 \%$

$0 \%$

$26 \%$

$11 \%$

$14 \%$

$37 \%$

$24 \%$

$28 \%$

$46 \%$

$8 \%$

$80 \%$

$19 \%$

$37 \%$
$98 \% \quad 2 \%$

$90 \% \quad 10 \%$

$66 \% \quad 34 \%$

$93 \% \quad 7 \%$

$47 \% \quad 53 \%$

$67 \% \quad 33 \%$

$41 \% \quad 59 \%$

$47 \% \quad 53 \%$

93\% $7 \%$

$74 \% \quad 26 \%$

$16 \% \quad 84 \%$

$90 \% \quad 10 \%$

$47 \% \quad 53 \%$

$44 \% \quad 56 \%$

$36 \% \quad 64 \%$

$68 \% \quad 32 \%$

$5 \% \quad 95 \%$

$14 \% \quad 86 \%$

$0 \% \quad 100 \%$

$72 \% \quad 28 \%$ 
Wetland Landscape Profiling of Palustrine Wetlands: Sixth-Code Hydrological Unit 6th Code HUC Name HUC Number Private State Federal Tribal Protected Natural Altered

\begin{tabular}{|c|c|c|c|c|c|c|c|c|}
\hline Chip Creek & 100302032204 & $96 \%$ & $3 \%$ & $1 \%$ & $0 \%$ & $100 \%$ & $65 \%$ & $35 \%$ \\
\hline Dry Fork Coulee East & 100302032205 & $81 \%$ & $19 \%$ & $0 \%$ & $0 \%$ & $100 \%$ & $12 \%$ & $88 \%$ \\
\hline Marias River-Loma & 100302032206 & $93 \%$ & $4 \%$ & $3 \%$ & $0 \%$ & $9 \%$ & $67 \%$ & $33 \%$ \\
\hline Fifteenmile Coulee & 100302040101 & $84 \%$ & $15 \%$ & $1 \%$ & $0 \%$ & $88 \%$ & $89 \%$ & $11 \%$ \\
\hline Black Coulee & 100302040102 & $92 \%$ & $8 \%$ & $0 \%$ & $0 \%$ & $34 \%$ & $63 \%$ & $37 \%$ \\
\hline Upper Trail Creek & 100302040201 & $93 \%$ & $5 \%$ & $2 \%$ & $0 \%$ & $100 \%$ & $72 \%$ & $28 \%$ \\
\hline Lower Trail Creek & 100302040202 & $90 \%$ & $10 \%$ & $0 \%$ & $0 \%$ & $0 \%$ & $55 \%$ & $45 \%$ \\
\hline Upper Miners Coulee & 100302040301 & $94 \%$ & $1 \%$ & $4 \%$ & $0 \%$ & $25 \%$ & $81 \%$ & $19 \%$ \\
\hline Lower Miners Coulee & 100302040302 & $84 \%$ & $16 \%$ & $0 \%$ & $0 \%$ & $20 \%$ & $78 \%$ & $22 \%$ \\
\hline Upper-Upper Willow Creek & 100302040303 & $92 \%$ & $8 \%$ & $0 \%$ & $0 \%$ & $25 \%$ & $78 \%$ & $22 \%$ \\
\hline Middle-Upper Willow Creek & 100302040304 & $91 \%$ & $9 \%$ & $0 \%$ & $0 \%$ & $16 \%$ & $69 \%$ & $31 \%$ \\
\hline Sheep Creek & 100302040305 & $82 \%$ & $18 \%$ & $0 \%$ & $0 \%$ & $100 \%$ & $69 \%$ & $31 \%$ \\
\hline Lower-Upper Willow Creek & 100302040306 & $67 \%$ & $33 \%$ & $0 \%$ & $0 \%$ & $86 \%$ & $73 \%$ & $27 \%$ \\
\hline Upper Dunkirk Coulee & 100302040401 & $100 \%$ & $0 \%$ & $0 \%$ & $0 \%$ & $100 \%$ & $46 \%$ & $54 \%$ \\
\hline Lower Dunkirk Coulee & 100302040402 & $100 \%$ & $0 \%$ & $0 \%$ & $0 \%$ & $0 \%$ & $86 \%$ & $14 \%$ \\
\hline Upper West Fork Willow Creek & 100302040403 & $94 \%$ & $6 \%$ & $0 \%$ & $0 \%$ & $3 \%$ & $76 \%$ & $24 \%$ \\
\hline Antelope Coulee & 100302040404 & $96 \%$ & $4 \%$ & $0 \%$ & $0 \%$ & $8 \%$ & $65 \%$ & $35 \%$ \\
\hline Crooked Coulee & 100302040405 & $91 \%$ & $9 \%$ & $0 \%$ & $0 \%$ & $33 \%$ & $75 \%$ & $25 \%$ \\
\hline Lower West Fork Willow Creek & 100302040406 & $98 \%$ & $2 \%$ & $0 \%$ & $0 \%$ & $80 \%$ & $63 \%$ & $37 \%$ \\
\hline Upper Eagle Creek & 100302040501 & $79 \%$ & $21 \%$ & $0 \%$ & $0 \%$ & $3 \%$ & $78 \%$ & $22 \%$ \\
\hline Lower Eagle Creek & 100302040502 & $84 \%$ & $16 \%$ & $0 \%$ & $0 \%$ & $44 \%$ & $76 \%$ & $24 \%$ \\
\hline Upper-Lower Willow Creek & 100302040601 & $99 \%$ & $1 \%$ & $0 \%$ & $0 \%$ & $34 \%$ & $31 \%$ & $69 \%$ \\
\hline Kinyon Coulee & 100302040602 & $98 \%$ & $2 \%$ & $0 \%$ & $0 \%$ & $54 \%$ & $62 \%$ & $38 \%$ \\
\hline Middle-Lower Willow Creek & 100302040603 & $98 \%$ & $2 \%$ & $0 \%$ & $0 \%$ & $100 \%$ & $37 \%$ & $63 \%$ \\
\hline Lower-Lower Willow Creek & 100302040604 & $71 \%$ & $1 \%$ & $28 \%$ & $0 \%$ & $19 \%$ & $52 \%$ & $48 \%$ \\
\hline Upper North Fork Teton River & 100302050101 & $0 \%$ & $0 \%$ & $100 \%$ & $0 \%$ & $8 \%$ & $100 \%$ & $0 \%$ \\
\hline Lower North Fork Teton River & 100302050102 & $0 \%$ & $0 \%$ & $100 \%$ & $0 \%$ & $21 \%$ & $99 \%$ & $1 \%$ \\
\hline South Fork Teton River & 100302050103 & $0 \%$ & $0 \%$ & $100 \%$ & $0 \%$ & $83 \%$ & $100 \%$ & $0 \%$ \\
\hline Middle Fork Teton River & 100302050104 & $2 \%$ & $0 \%$ & $98 \%$ & $0 \%$ & $78 \%$ & $99 \%$ & $1 \%$ \\
\hline Teton River-McDonald Creek & 100302050105 & $61 \%$ & $0 \%$ & $39 \%$ & $0 \%$ & $6 \%$ & $100 \%$ & $0 \%$ \\
\hline South Fork Willow Creek & 100302050201 & $0 \%$ & $0 \%$ & $100 \%$ & $0 \%$ & $64 \%$ & $95 \%$ & $5 \%$ \\
\hline North Fork Willow Creek & 100302050202 & $86 \%$ & $0 \%$ & $14 \%$ & $0 \%$ & $60 \%$ & $100 \%$ & $0 \%$ \\
\hline Upper Willow Creek & 100302050203 & $0 \%$ & $0 \%$ & $100 \%$ & $0 \%$ & $42 \%$ & $96 \%$ & $4 \%$ \\
\hline Lower Willow Creek & 100302050204 & $3 \%$ & $0 \%$ & $97 \%$ & $0 \%$ & $23 \%$ & $89 \%$ & $11 \%$ \\
\hline Upper Deep Creek & 100302050301 & $0 \%$ & $0 \%$ & $100 \%$ & $0 \%$ & $100 \%$ & $81 \%$ & $19 \%$ \\
\hline Hay Coulee & 100302050302 & $49 \%$ & $0 \%$ & $51 \%$ & $0 \%$ & $100 \%$ & $63 \%$ & $37 \%$ \\
\hline Nunemaker Coulee & 100302050303 & $81 \%$ & $18 \%$ & $1 \%$ & $0 \%$ & $36 \%$ & $68 \%$ & $32 \%$ \\
\hline Dog Creek & 100302050304 & $51 \%$ & $1 \%$ & $48 \%$ & $0 \%$ & $2 \%$ & $51 \%$ & $49 \%$ \\
\hline Middle Deep Creek & 100302050305 & $44 \%$ & $1 \%$ & $54 \%$ & $0 \%$ & $46 \%$ & $84 \%$ & $16 \%$ \\
\hline Lower Deep Creek & 100302050306 & $98 \%$ & $2 \%$ & $0 \%$ & $0 \%$ & $18 \%$ & $92 \%$ & $8 \%$ \\
\hline Teton River-Hod Main Coulee & 100302050401 & $84 \%$ & $14 \%$ & $2 \%$ & $0 \%$ & $46 \%$ & $87 \%$ & $13 \%$ \\
\hline Upper Freezeout Lake & 100302050402 & $22 \%$ & $75 \%$ & $3 \%$ & $0 \%$ & $19 \%$ & $63 \%$ & $37 \%$ \\
\hline Roundup Coulee & 100302050403 & $74 \%$ & $26 \%$ & $0 \%$ & $0 \%$ & $62 \%$ & $54 \%$ & $46 \%$ \\
\hline Lower Freezeout Lake & 100302050404 & $23 \%$ & $73 \%$ & $4 \%$ & $0 \%$ & $79 \%$ & $45 \%$ & $55 \%$ \\
\hline Teton River-Spring Coulee & 100302050405 & $74 \%$ & $26 \%$ & $0 \%$ & $0 \%$ & $92 \%$ & $100 \%$ & $0 \%$ \\
\hline Teton River-Gamble Coulee & 100302050406 & $100 \%$ & $0 \%$ & $0 \%$ & $0 \%$ & $83 \%$ & $91 \%$ & $9 \%$ \\
\hline Upper Spring Coulee & 100302050501 & $100 \%$ & $0 \%$ & $0 \%$ & $0 \%$ & $29 \%$ & $99 \%$ & $1 \%$ \\
\hline Lower Spring Coulee & 100302050502 & $100 \%$ & $0 \%$ & $0 \%$ & $0 \%$ & $66 \%$ & $90 \%$ & $10 \%$ \\
\hline Muddy Creek-Rinker Creek & 100302050601 & $11 \%$ & $42 \%$ & $47 \%$ & $0 \%$ & $83 \%$ & $69 \%$ & $31 \%$ \\
\hline Blindhorse Creek & 100302050602 & $48 \%$ & $48 \%$ & $4 \%$ & $0 \%$ & $17 \%$ & $95 \%$ & $5 \%$ \\
\hline Blackleaf Creek & 100302050603 & $72 \%$ & $0 \%$ & $27 \%$ & $0 \%$ & $14 \%$ & $98 \%$ & $2 \%$ \\
\hline Muddy Creek-Miller Creek & 100302050604 & $78 \%$ & $0 \%$ & $22 \%$ & $0 \%$ & $37 \%$ & $94 \%$ & $6 \%$ \\
\hline
\end{tabular}


Wetland Landscape Profiling of Palustrine Wetlands: Sixth-Code Hydrological Unit 6th Code HUC Name HUC Number Private State Federal Tribal Protected Natural Altered

\begin{tabular}{|c|c|c|c|c|c|c|c|c|}
\hline Muddy Creek-Bynum & 100302050701 & $25 \%$ & $0 \%$ & $75 \%$ & $0 \%$ & $6 \%$ & $91 \%$ & $9 \%$ \\
\hline Muddy Creek-Foster Creek & 100302050702 & $65 \%$ & $0 \%$ & $35 \%$ & $0 \%$ & $100 \%$ & $98 \%$ & $2 \%$ \\
\hline Jones Creek & 100302050801 & $99 \%$ & $1 \%$ & $0 \%$ & $0 \%$ & $38 \%$ & $95 \%$ & $5 \%$ \\
\hline Farmer Coulee & 100302050802 & $97 \%$ & $2 \%$ & $0 \%$ & $0 \%$ & $100 \%$ & $86 \%$ & $14 \%$ \\
\hline Kropp Coulee & 100302050803 & $91 \%$ & $9 \%$ & $0 \%$ & $0 \%$ & $9 \%$ & $97 \%$ & $3 \%$ \\
\hline Muddy Creek-Eyraud Lakes & 100302050804 & $85 \%$ & $11 \%$ & $3 \%$ & $0 \%$ & $24 \%$ & $100 \%$ & $0 \%$ \\
\hline Muddy Creek & 100302050805 & $96 \%$ & $4 \%$ & $0 \%$ & $0 \%$ & $80 \%$ & $95 \%$ & $5 \%$ \\
\hline Teton River-Alkali Flat & 100302050901 & $100 \%$ & $0 \%$ & $0 \%$ & $0 \%$ & $26 \%$ & $97 \%$ & $3 \%$ \\
\hline Teton River-Collins & 100302050902 & $100 \%$ & $0 \%$ & $0 \%$ & $0 \%$ & $51 \%$ & $80 \%$ & $20 \%$ \\
\hline Old Railroad Coulee & 100302050903 & $100 \%$ & $0 \%$ & $0 \%$ & $0 \%$ & $91 \%$ & $69 \%$ & $31 \%$ \\
\hline Upper Muddy Creek & 100302050904 & $99 \%$ & $1 \%$ & $0 \%$ & $0 \%$ & $49 \%$ & $57 \%$ & $43 \%$ \\
\hline Kerr Bridge & 100302050905 & $77 \%$ & $23 \%$ & $0 \%$ & $0 \%$ & $33 \%$ & $99 \%$ & $1 \%$ \\
\hline Kinnerely Coulee & 100302051001 & $95 \%$ & $1 \%$ & $4 \%$ & $0 \%$ & $36 \%$ & $88 \%$ & $12 \%$ \\
\hline Flat Coulee & 100302051002 & $99 \%$ & $1 \%$ & $0 \%$ & $0 \%$ & $9 \%$ & $68 \%$ & $32 \%$ \\
\hline Teton River-Rye Coulee & 100302051003 & $81 \%$ & $19 \%$ & $0 \%$ & $0 \%$ & $20 \%$ & $95 \%$ & $5 \%$ \\
\hline East Fork Timber Coulee & 100302051004 & $89 \%$ & $11 \%$ & $0 \%$ & $0 \%$ & $8 \%$ & $45 \%$ & $55 \%$ \\
\hline Timber Coulee & 100302051005 & $100 \%$ & $0 \%$ & $0 \%$ & $0 \%$ & $91 \%$ & $42 \%$ & $58 \%$ \\
\hline Berry Coulee & 100302051006 & $95 \%$ & $5 \%$ & $0 \%$ & $0 \%$ & $25 \%$ & $82 \%$ & $18 \%$ \\
\hline Teton River-Sheep Coulee & 100302051007 & $99 \%$ & $1 \%$ & $0 \%$ & $0 \%$ & $100 \%$ & $68 \%$ & $32 \%$ \\
\hline East-West Knee & 100302051101 & $96 \%$ & $4 \%$ & $0 \%$ & $0 \%$ & $63 \%$ & $80 \%$ & $20 \%$ \\
\hline Teton River-100302051102 & 100302051102 & $97 \%$ & $3 \%$ & $0 \%$ & $0 \%$ & $50 \%$ & $13 \%$ & $87 \%$ \\
\hline Teton River-Dent Bridge & 100302051103 & $72 \%$ & $28 \%$ & $0 \%$ & $0 \%$ & $84 \%$ & $78 \%$ & $22 \%$ \\
\hline Antelope Coulee & 100302051104 & $98 \%$ & $2 \%$ & $0 \%$ & $0 \%$ & $3 \%$ & $96 \%$ & $4 \%$ \\
\hline Weatherman Coulee & 100302051105 & $97 \%$ & $3 \%$ & $0 \%$ & $0 \%$ & $24 \%$ & $78 \%$ & $22 \%$ \\
\hline Teton River-Frank Gilbert & 100302051106 & $100 \%$ & $0 \%$ & $0 \%$ & $0 \%$ & $91 \%$ & $88 \%$ & $12 \%$ \\
\hline Chimney Rock Coulee & 100302051201 & $94 \%$ & $6 \%$ & $0 \%$ & $0 \%$ & $69 \%$ & $47 \%$ & $53 \%$ \\
\hline West Fork Dry Coulee & 100302051202 & $100 \%$ & $0 \%$ & $0 \%$ & $0 \%$ & $10 \%$ & $8 \%$ & $92 \%$ \\
\hline Dry Fork Coulee & 100302051203 & $98 \%$ & $2 \%$ & $0 \%$ & $0 \%$ & $0 \%$ & $14 \%$ & $86 \%$ \\
\hline Teton River-Eightmile Coulee & 100302051204 & $92 \%$ & $8 \%$ & $0 \%$ & $0 \%$ & $12 \%$ & $78 \%$ & $22 \%$ \\
\hline Teton River-Collins School & 100302051205 & $46 \%$ & $52 \%$ & $3 \%$ & $0 \%$ & $48 \%$ & $87 \%$ & $13 \%$ \\
\hline Lower Little Sandy Creek & 100401010101 & $0 \%$ & $0 \%$ & $0 \%$ & $0 \%$ & $100 \%$ & $0 \%$ & $0 \%$ \\
\hline Upper Little Sandy Creek & 100401010102 & $100 \%$ & $0 \%$ & $0 \%$ & $0 \%$ & $49 \%$ & $100 \%$ & $0 \%$ \\
\hline Little Eagle Creek & 100401010201 & $0 \%$ & $0 \%$ & $0 \%$ & $0 \%$ & $28 \%$ & $0 \%$ & $0 \%$ \\
\hline Missouri River-Archers Island & 100401010302 & $0 \%$ & $0 \%$ & $0 \%$ & $0 \%$ & $4 \%$ & $0 \%$ & $0 \%$ \\
\hline Six Mile Coulee & 100401010303 & $0 \%$ & $0 \%$ & $0 \%$ & $0 \%$ & $19 \%$ & $0 \%$ & $0 \%$ \\
\hline Spring Coulee & 100401010304 & $0 \%$ & $0 \%$ & $0 \%$ & $0 \%$ & $30 \%$ & $0 \%$ & $0 \%$ \\
\hline Coal Banks Coulee & 100401010305 & $0 \%$ & $0 \%$ & $0 \%$ & $0 \%$ & $58 \%$ & $0 \%$ & $0 \%$ \\
\hline Upper Birch Creek & 100401010801 & $0 \%$ & $0 \%$ & $0 \%$ & $0 \%$ & $10 \%$ & $0 \%$ & $0 \%$ \\
\hline Upper Suction Creek & 100401040101 & $0 \%$ & $0 \%$ & $0 \%$ & $0 \%$ & $69 \%$ & $0 \%$ & $0 \%$ \\
\hline Upper Little Suction Creek & 100401040103 & $0 \%$ & $0 \%$ & $0 \%$ & $0 \%$ & $46 \%$ & $0 \%$ & $0 \%$ \\
\hline Lower Little Suction Creek & 100401040104 & $0 \%$ & $0 \%$ & $0 \%$ & $0 \%$ & $11 \%$ & $0 \%$ & $0 \%$ \\
\hline Lower Suction Creek & 100401040105 & $0 \%$ & $0 \%$ & $0 \%$ & $0 \%$ & $78 \%$ & $0 \%$ & $0 \%$ \\
\hline North Fork of Cow Creek & 100401040201 & $0 \%$ & $0 \%$ & $0 \%$ & $0 \%$ & $21 \%$ & $0 \%$ & $0 \%$ \\
\hline South Fork of Cow Creek & 100401040202 & $0 \%$ & $0 \%$ & $0 \%$ & $0 \%$ & $30 \%$ & $0 \%$ & $0 \%$ \\
\hline Gap Creek & 100401040203 & $0 \%$ & $0 \%$ & $0 \%$ & $0 \%$ & $4 \%$ & $0 \%$ & $0 \%$ \\
\hline Upper Cow Creek & 100401040205 & $0 \%$ & $0 \%$ & $0 \%$ & $0 \%$ & $98 \%$ & $0 \%$ & $0 \%$ \\
\hline Squaw Creek & 100401040207 & $0 \%$ & $0 \%$ & $0 \%$ & $0 \%$ & $49 \%$ & $0 \%$ & $0 \%$ \\
\hline Upper Rock Creek & 100401040602 & $0 \%$ & $0 \%$ & $0 \%$ & $0 \%$ & $74 \%$ & $0 \%$ & $0 \%$ \\
\hline Bull Creek & 100401040701 & $0 \%$ & $0 \%$ & $0 \%$ & $0 \%$ & $6 \%$ & $0 \%$ & $0 \%$ \\
\hline Upper CK Creek & 100401040801 & $0 \%$ & $0 \%$ & $0 \%$ & $0 \%$ & $37 \%$ & $0 \%$ & $0 \%$ \\
\hline Upper Beauchamp Creek & 100401040901 & $0 \%$ & $0 \%$ & $0 \%$ & $0 \%$ & $9 \%$ & $0 \%$ & $0 \%$ \\
\hline Dry Fork Creek & 100401040903 & $0 \%$ & $0 \%$ & $0 \%$ & $0 \%$ & $23 \%$ & $0 \%$ & $0 \%$ \\
\hline
\end{tabular}


Wetland Landscape Profiling of Palustrine Wetlands: Sixth-Code Hydrological Unit 6th Code HUC Name HUC Number Private State Federal Tribal Protected Natural Altered

\begin{tabular}{|c|c|c|c|c|c|c|c|c|}
\hline Tank Coulee & 100401041201 & $0 \%$ & $0 \%$ & $0 \%$ & $0 \%$ & $35 \%$ & $0 \%$ & $0 \%$ \\
\hline Second Creek & 100401041202 & $0 \%$ & $0 \%$ & $0 \%$ & $0 \%$ & $0 \%$ & $0 \%$ & $0 \%$ \\
\hline Upper Telegraph Creek & 100401041204 & $0 \%$ & $0 \%$ & $0 \%$ & $0 \%$ & $98 \%$ & $0 \%$ & $0 \%$ \\
\hline Lone Tree Coulee & 100401041501 & $0 \%$ & $0 \%$ & $0 \%$ & $0 \%$ & $35 \%$ & $0 \%$ & $0 \%$ \\
\hline Square Creek & 100401041502 & $0 \%$ & $0 \%$ & $0 \%$ & $0 \%$ & $22 \%$ & $0 \%$ & $0 \%$ \\
\hline Shotgun Coulee & 100401041503 & $0 \%$ & $0 \%$ & $0 \%$ & $0 \%$ & $78 \%$ & $0 \%$ & $0 \%$ \\
\hline Upper Timber Creek & 100401041504 & $0 \%$ & $0 \%$ & $0 \%$ & $0 \%$ & $29 \%$ & $0 \%$ & $0 \%$ \\
\hline Plum Coulee & 100401041505 & $0 \%$ & $0 \%$ & $0 \%$ & $0 \%$ & $18 \%$ & $0 \%$ & $0 \%$ \\
\hline Upper Sutherland Creek & 100401041901 & $0 \%$ & $0 \%$ & $0 \%$ & $0 \%$ & $43 \%$ & $0 \%$ & $0 \%$ \\
\hline Lower Sutherland Creek & 100401041903 & $0 \%$ & $0 \%$ & $0 \%$ & $0 \%$ & $29 \%$ & $0 \%$ & $0 \%$ \\
\hline Duck Creek & 100401042005 & $0 \%$ & $0 \%$ & $0 \%$ & $0 \%$ & $0 \%$ & $0 \%$ & $0 \%$ \\
\hline Upper Eighth Coulee & 100401042006 & $0 \%$ & $0 \%$ & $0 \%$ & $0 \%$ & $40 \%$ & $0 \%$ & $0 \%$ \\
\hline Middle Eighth Coulee & 100401042007 & $0 \%$ & $0 \%$ & $0 \%$ & $0 \%$ & $31 \%$ & $0 \%$ & $0 \%$ \\
\hline Seventh Coulee & 100401042701 & $0 \%$ & $0 \%$ & $0 \%$ & $0 \%$ & $94 \%$ & $0 \%$ & $0 \%$ \\
\hline Sixth Coulee & 100401042703 & $0 \%$ & $0 \%$ & $0 \%$ & $0 \%$ & $0 \%$ & $0 \%$ & $0 \%$ \\
\hline Fifth Coulee & 100401042704 & $0 \%$ & $0 \%$ & $0 \%$ & $0 \%$ & $0 \%$ & $0 \%$ & $0 \%$ \\
\hline South Fork Duck Creek & 100401042707 & $0 \%$ & $0 \%$ & $0 \%$ & $0 \%$ & $24 \%$ & $0 \%$ & $0 \%$ \\
\hline $\begin{array}{l}\text { Missouri River- } \\
\quad \text { North Fork Duck Creek }\end{array}$ & 100401042709 & $0 \%$ & $0 \%$ & $0 \%$ & $0 \%$ & $82 \%$ & $0 \%$ & $0 \%$ \\
\hline Upper South Fork Milk River & 100500010101 & $0 \%$ & $0 \%$ & $0 \%$ & $100 \%$ & $84 \%$ & $100 \%$ & $0 \%$ \\
\hline Middle South Fork Milk River & 100500010102 & $0 \%$ & $0 \%$ & $0 \%$ & $100 \%$ & $96 \%$ & $100 \%$ & $0 \%$ \\
\hline Livermore Creek & 100500010103 & $0 \%$ & $0 \%$ & $0 \%$ & $100 \%$ & $3 \%$ & $98 \%$ & $2 \%$ \\
\hline Upper Middle Fork Milk River & 100500010104 & $0 \%$ & $0 \%$ & $0 \%$ & $100 \%$ & $89 \%$ & $97 \%$ & $3 \%$ \\
\hline Lower Middle Fork Milk River & 100500010105 & $0 \%$ & $0 \%$ & $0 \%$ & $100 \%$ & $5 \%$ & $97 \%$ & $3 \%$ \\
\hline Lower South Fork Milk River & 100500010106 & $0 \%$ & $0 \%$ & $0 \%$ & $100 \%$ & $2 \%$ & $95 \%$ & $5 \%$ \\
\hline Upper North Fork Milk River & 100500010201 & $0 \%$ & $0 \%$ & $0 \%$ & $100 \%$ & $89 \%$ & $99 \%$ & $1 \%$ \\
\hline Middle North Fork Milk River & 100500010202 & $0 \%$ & $0 \%$ & $0 \%$ & $100 \%$ & $100 \%$ & $78 \%$ & $22 \%$ \\
\hline Lower North Fork Milk River & 100500010203 & $0 \%$ & $0 \%$ & $0 \%$ & $100 \%$ & $18 \%$ & $98 \%$ & $2 \%$ \\
\hline Milk River-Red Buttes & 100500010301 & $0 \%$ & $0 \%$ & $0 \%$ & $100 \%$ & $97 \%$ & $28 \%$ & $72 \%$ \\
\hline Milk River-Kennedy Coulee & 100500010302 & $0 \%$ & $0 \%$ & $0 \%$ & $100 \%$ & $15 \%$ & $93 \%$ & $7 \%$ \\
\hline Milk River-Coal Bank Coulee & 100500010303 & $0 \%$ & $0 \%$ & $0 \%$ & $100 \%$ & $100 \%$ & $95 \%$ & $5 \%$ \\
\hline Milk River-Antelope Spring & 100500010304 & $0 \%$ & $0 \%$ & $0 \%$ & $100 \%$ & $63 \%$ & $94 \%$ & $6 \%$ \\
\hline Oil Field & 100500020101 & $89 \%$ & $11 \%$ & $0 \%$ & $0 \%$ & $7 \%$ & $93 \%$ & $7 \%$ \\
\hline Fitzpatrick Coulee & 100500020102 & $93 \%$ & $7 \%$ & $0 \%$ & $0 \%$ & $100 \%$ & $80 \%$ & $20 \%$ \\
\hline Rim Rock Colony & 100500020103 & $85 \%$ & $15 \%$ & $0 \%$ & $0 \%$ & $59 \%$ & $86 \%$ & $14 \%$ \\
\hline Red River & 100500020104 & $93 \%$ & $7 \%$ & $0 \%$ & $0 \%$ & $49 \%$ & $87 \%$ & $13 \%$ \\
\hline Sweetgrass & 100500020200 & $100 \%$ & $0 \%$ & $0 \%$ & $0 \%$ & $38 \%$ & $89 \%$ & $11 \%$ \\
\hline Beaupre Coulee & 100500020301 & $97 \%$ & $2 \%$ & $1 \%$ & $0 \%$ & $4 \%$ & $89 \%$ & $11 \%$ \\
\hline Police Creek & 100500020302 & $98 \%$ & $2 \%$ & $0 \%$ & $0 \%$ & $0 \%$ & $63 \%$ & $37 \%$ \\
\hline Upper Miners Coulee & 100500020401 & $84 \%$ & $4 \%$ & $13 \%$ & $0 \%$ & $96 \%$ & $82 \%$ & $18 \%$ \\
\hline Breed Creek & 100500020402 & $79 \%$ & $2 \%$ & $19 \%$ & $0 \%$ & $1 \%$ & $80 \%$ & $20 \%$ \\
\hline Police Creek & 100500020403 & $78 \%$ & $22 \%$ & $0 \%$ & $0 \%$ & $43 \%$ & $86 \%$ & $14 \%$ \\
\hline Bear Gulch & 100500020404 & $97 \%$ & $3 \%$ & $0 \%$ & $0 \%$ & $51 \%$ & $74 \%$ & $26 \%$ \\
\hline Lower Miners Coulee & 100500020405 & $87 \%$ & $1 \%$ & $12 \%$ & $0 \%$ & $18 \%$ & $70 \%$ & $30 \%$ \\
\hline Upper Spring Coulee & 100500020501 & $93 \%$ & $7 \%$ & $0 \%$ & $0 \%$ & $2 \%$ & $61 \%$ & $39 \%$ \\
\hline Lower Springe Coulee & 100500020502 & $32 \%$ & $8 \%$ & $60 \%$ & $0 \%$ & $7 \%$ & $97 \%$ & $3 \%$ \\
\hline Upper Ninemile Coulee & 100500020601 & $90 \%$ & $10 \%$ & $0 \%$ & $0 \%$ & $86 \%$ & $35 \%$ & $65 \%$ \\
\hline Middle Ninemile Coulee & 100500020602 & $68 \%$ & $31 \%$ & $1 \%$ & $0 \%$ & $90 \%$ & $55 \%$ & $45 \%$ \\
\hline Lower Ninemile Coulee & 100500020603 & $22 \%$ & $0 \%$ & $78 \%$ & $0 \%$ & $95 \%$ & $90 \%$ & $10 \%$ \\
\hline Dry Lake Coulee & 100500020701 & $79 \%$ & $9 \%$ & $12 \%$ & $0 \%$ & $17 \%$ & $98 \%$ & $2 \%$ \\
\hline Upper Chain of Lakes Coulee & 100500020702 & $82 \%$ & $2 \%$ & $16 \%$ & $0 \%$ & $66 \%$ & $90 \%$ & $10 \%$ \\
\hline Milk River-Kennedy Coulee & 100500020801 & $95 \%$ & $5 \%$ & $0 \%$ & $0 \%$ & $1 \%$ & $87 \%$ & $13 \%$ \\
\hline
\end{tabular}


Wetland Landscape Profiling of Palustrine Wetlands: Sixth-Code Hydrological Unit 6th Code HUC Name HUC Number Private State Federal Tribal Protected Natural Altered

\begin{tabular}{|c|c|c|c|c|c|c|c|c|}
\hline Milk RIver-Lost River & 100500020802 & $94 \%$ & $6 \%$ & $0 \%$ & $0 \%$ & $20 \%$ & $73 \%$ & $27 \%$ \\
\hline Milk River-Spring Coulee & 100500020803 & $27 \%$ & $3 \%$ & $71 \%$ & $0 \%$ & $10 \%$ & $98 \%$ & $2 \%$ \\
\hline 100500020804 & 100500020804 & $90 \%$ & $10 \%$ & $0 \%$ & $0 \%$ & $0 \%$ & $63 \%$ & $37 \%$ \\
\hline 100500020805 & 100500020805 & $90 \%$ & $9 \%$ & $1 \%$ & $0 \%$ & $100 \%$ & $74 \%$ & $26 \%$ \\
\hline Archie Coulee & 100500020806 & $47 \%$ & $2 \%$ & $51 \%$ & $0 \%$ & $40 \%$ & $65 \%$ & $35 \%$ \\
\hline Milk River-Upper Fresno Reservoi & ir 100500020807 & $7 \%$ & $1 \%$ & $92 \%$ & $0 \%$ & $15 \%$ & $64 \%$ & $36 \%$ \\
\hline Cottonwood Coulee & 100500020808 & $86 \%$ & $4 \%$ & $10 \%$ & $0 \%$ & $65 \%$ & $70 \%$ & $30 \%$ \\
\hline Milk River-Lower Fresno Reservo & ir100500020809 & $72 \%$ & $5 \%$ & $24 \%$ & $0 \%$ & $100 \%$ & $61 \%$ & $39 \%$ \\
\hline Wild Horse Lake & 100500030100 & $99 \%$ & $0 \%$ & $0 \%$ & $0 \%$ & $5 \%$ & $99 \%$ & $1 \%$ \\
\hline Upper Beaver Creek & 100500040101 & $43 \%$ & $0 \%$ & $0 \%$ & $41 \%$ & $8 \%$ & $85 \%$ & $15 \%$ \\
\hline Middle Beaver Creek & 100500040102 & $53 \%$ & $2 \%$ & $0 \%$ & $0 \%$ & $62 \%$ & $76 \%$ & $24 \%$ \\
\hline Lower Beaver Creek & 100500040103 & $96 \%$ & $1 \%$ & $0 \%$ & $0 \%$ & $5 \%$ & $62 \%$ & $38 \%$ \\
\hline Upper Little Boxelder Creek & 100500040201 & $100 \%$ & $0 \%$ & $0 \%$ & $0 \%$ & $33 \%$ & $97 \%$ & $3 \%$ \\
\hline Lower Little Boxelder Creek & 100500040202 & $98 \%$ & $2 \%$ & $0 \%$ & $0 \%$ & $43 \%$ & $74 \%$ & $26 \%$ \\
\hline Upper Clear Creek & 100500040301 & $98 \%$ & $2 \%$ & $0 \%$ & $0 \%$ & $1 \%$ & $93 \%$ & $7 \%$ \\
\hline Middle Clear Creek & 100500040302 & $100 \%$ & $0 \%$ & $0 \%$ & $0 \%$ & $26 \%$ & $83 \%$ & $17 \%$ \\
\hline Lower Clear Creek & 100500040303 & $95 \%$ & $3 \%$ & $2 \%$ & $0 \%$ & $57 \%$ & $87 \%$ & $13 \%$ \\
\hline Fresno Coulee & 100500040401 & $99 \%$ & $1 \%$ & $0 \%$ & $0 \%$ & $6 \%$ & $43 \%$ & $57 \%$ \\
\hline Milk River-Nelson Coulee & 100500040402 & $86 \%$ & $14 \%$ & $0 \%$ & $0 \%$ & $77 \%$ & $30 \%$ & $70 \%$ \\
\hline Bullhook Creek & 100500040403 & $99 \%$ & $1 \%$ & $0 \%$ & $0 \%$ & $15 \%$ & $55 \%$ & $45 \%$ \\
\hline Milk River-Havre & 100500040404 & $57 \%$ & $43 \%$ & $0 \%$ & $0 \%$ & $8 \%$ & $73 \%$ & $27 \%$ \\
\hline Milk River-Davey Coulee & 100500040405 & $74 \%$ & $26 \%$ & $0 \%$ & $0 \%$ & $52 \%$ & $75 \%$ & $25 \%$ \\
\hline Dog Coulee & 100500040501 & $95 \%$ & $5 \%$ & $0 \%$ & $0 \%$ & $29 \%$ & $74 \%$ & $26 \%$ \\
\hline Staton Coulee & 100500040502 & $94 \%$ & $6 \%$ & $0 \%$ & $0 \%$ & $6 \%$ & $65 \%$ & $35 \%$ \\
\hline Lohman Coulee & 100500040503 & $97 \%$ & $1 \%$ & $1 \%$ & $0 \%$ & $1 \%$ & $91 \%$ & $9 \%$ \\
\hline Upper Redrock Coulee & 100500040504 & $88 \%$ & $12 \%$ & $0 \%$ & $0 \%$ & $8 \%$ & $56 \%$ & $44 \%$ \\
\hline Coal Coulee & 100500040505 & $79 \%$ & $21 \%$ & $0 \%$ & $0 \%$ & $38 \%$ & $48 \%$ & $52 \%$ \\
\hline Middle Redrock Coulee & 100500040506 & $93 \%$ & $1 \%$ & $5 \%$ & $0 \%$ & $0 \%$ & $87 \%$ & $13 \%$ \\
\hline Lower Redrock Coulee & 100500040507 & $75 \%$ & $1 \%$ & $25 \%$ & $0 \%$ & $0 \%$ & $63 \%$ & $37 \%$ \\
\hline Black Coulee & 100500040601 & $95 \%$ & $5 \%$ & $0 \%$ & $0 \%$ & $0 \%$ & $60 \%$ & $40 \%$ \\
\hline Lone Tree Coulee & 100500040602 & $100 \%$ & $0 \%$ & $0 \%$ & $0 \%$ & $86 \%$ & $48 \%$ & $52 \%$ \\
\hline Milk River-Sixteen Mile Creek & 100500040603 & $98 \%$ & $2 \%$ & $0 \%$ & $0 \%$ & $0 \%$ & $87 \%$ & $13 \%$ \\
\hline Fifteen Mile Creek & 100500040604 & $68 \%$ & $8 \%$ & $24 \%$ & $0 \%$ & $0 \%$ & $66 \%$ & $34 \%$ \\
\hline Milk River-Harlem Canal & 100500040605 & $90 \%$ & $4 \%$ & $6 \%$ & $0 \%$ & $11 \%$ & $92 \%$ & $8 \%$ \\
\hline Little Box Elder Coulee & 100500040701 & $45 \%$ & $55 \%$ & $0 \%$ & $0 \%$ & $40 \%$ & $73 \%$ & $27 \%$ \\
\hline Upper Box Elder Creek & 100500040702 & $91 \%$ & $9 \%$ & $0 \%$ & $0 \%$ & $71 \%$ & $55 \%$ & $45 \%$ \\
\hline Lower Box Elder Creek & 100500040703 & $98 \%$ & $2 \%$ & $0 \%$ & $0 \%$ & $2 \%$ & $52 \%$ & $48 \%$ \\
\hline Upper Snake Creek & 100500040801 & $95 \%$ & $5 \%$ & $0 \%$ & $0 \%$ & $92 \%$ & $64 \%$ & $36 \%$ \\
\hline Middle Snake Creek & 100500040802 & $93 \%$ & $4 \%$ & $3 \%$ & $0 \%$ & $0 \%$ & $49 \%$ & $51 \%$ \\
\hline Bean Creek & 100500040803 & $97 \%$ & $3 \%$ & $0 \%$ & $0 \%$ & $22 \%$ & $72 \%$ & $28 \%$ \\
\hline Lower Snake Creek & 100500040804 & $97 \%$ & $3 \%$ & $0 \%$ & $0 \%$ & $95 \%$ & $61 \%$ & $39 \%$ \\
\hline Northwest Fork Thirtymile Creek & 100500040901 & $83 \%$ & $5 \%$ & $11 \%$ & $1 \%$ & $8 \%$ & $70 \%$ & $30 \%$ \\
\hline Upper Thirtymile Creek & 100500040902 & $75 \%$ & $2 \%$ & $23 \%$ & $0 \%$ & $15 \%$ & $79 \%$ & $21 \%$ \\
\hline East Branch Thirtymile Creek & 100500040903 & $73 \%$ & $11 \%$ & $15 \%$ & $1 \%$ & $4 \%$ & $74 \%$ & $26 \%$ \\
\hline Lower Thirtymile Creek & 100500040904 & $59 \%$ & $14 \%$ & $27 \%$ & $0 \%$ & $5 \%$ & $80 \%$ & $20 \%$ \\
\hline West Fork Wayne Creek & 100500041001 & $88 \%$ & $0 \%$ & $12 \%$ & $0 \%$ & $0 \%$ & $78 \%$ & $22 \%$ \\
\hline East Fork Wayne Creek & 100500041002 & $93 \%$ & $3 \%$ & $4 \%$ & $0 \%$ & $78 \%$ & $97 \%$ & $3 \%$ \\
\hline Wayne Creek & 100500041003 & $69 \%$ & $19 \%$ & $12 \%$ & $0 \%$ & $0 \%$ & $88 \%$ & $12 \%$ \\
\hline Black Creek & 100500041101 & $82 \%$ & $5 \%$ & $13 \%$ & $0 \%$ & $18 \%$ & $78 \%$ & $22 \%$ \\
\hline Upper Savoy Creek & 100500041102 & $78 \%$ & $19 \%$ & $2 \%$ & $0 \%$ & $73 \%$ & $75 \%$ & $25 \%$ \\
\hline Lower Savoy Creek & 100500041103 & $84 \%$ & $0 \%$ & $16 \%$ & $0 \%$ & $0 \%$ & $93 \%$ & $7 \%$ \\
\hline Upper White Bear Creek & 100500041201 & $28 \%$ & $39 \%$ & $0 \%$ & $33 \%$ & $45 \%$ & $77 \%$ & $23 \%$ \\
\hline
\end{tabular}


Wetland Landscape Profiling of Palustrine Wetlands: Sixth-Code Hydrological Unit 6th Code HUC Name HUC Number Private State Federal Tribal Protected Natural Altered

\begin{tabular}{|c|c|c|c|c|c|c|c|c|}
\hline Upper Fifteen Mile Creek & 100500041202 & $16 \%$ & $14 \%$ & $0 \%$ & $70 \%$ & $8 \%$ & $83 \%$ & $17 \%$ \\
\hline Lower Fifteen Mile Creek & 100500041203 & $0 \%$ & $0 \%$ & $0 \%$ & $100 \%$ & $96 \%$ & $91 \%$ & $9 \%$ \\
\hline Lower White Bear Creek & 100500041204 & $0 \%$ & $0 \%$ & $0 \%$ & $100 \%$ & $33 \%$ & $58 \%$ & $42 \%$ \\
\hline Forgey Creek & 100500041301 & $74 \%$ & $10 \%$ & $16 \%$ & $0 \%$ & $95 \%$ & $52 \%$ & $48 \%$ \\
\hline Milk River-Harlem & 100500041302 & $45 \%$ & $0 \%$ & $0 \%$ & $54 \%$ & $51 \%$ & $92 \%$ & $8 \%$ \\
\hline Threemile Creek & 100500041303 & $6 \%$ & $0 \%$ & $0 \%$ & $94 \%$ & $24 \%$ & $61 \%$ & $39 \%$ \\
\hline Milk River -Threemile Reservoir & 100500041304 & $58 \%$ & $1 \%$ & $1 \%$ & $40 \%$ & $90 \%$ & $95 \%$ & $5 \%$ \\
\hline Milk Creek & 100500041305 & $78 \%$ & $11 \%$ & $10 \%$ & $0 \%$ & $0 \%$ & $74 \%$ & $26 \%$ \\
\hline Milk River-Milk Creek & 100500041306 & $52 \%$ & $1 \%$ & $1 \%$ & $46 \%$ & $1 \%$ & $52 \%$ & $48 \%$ \\
\hline 100500041401 & 100500041401 & $59 \%$ & $1 \%$ & $39 \%$ & $0 \%$ & $0 \%$ & $69 \%$ & $31 \%$ \\
\hline Upper Dodson Creek & 100500041402 & $83 \%$ & $3 \%$ & $14 \%$ & $0 \%$ & $39 \%$ & $88 \%$ & $12 \%$ \\
\hline Lower Dodson CreeK & 100500041403 & $96 \%$ & $2 \%$ & $1 \%$ & $0 \%$ & $100 \%$ & $75 \%$ & $25 \%$ \\
\hline Spring Coulee & 100500041501 & $99 \%$ & $0 \%$ & $1 \%$ & $0 \%$ & $0 \%$ & $88 \%$ & $12 \%$ \\
\hline Milk River-Cow Creek & 100500041502 & $92 \%$ & $0 \%$ & $8 \%$ & $0 \%$ & $7 \%$ & $73 \%$ & $27 \%$ \\
\hline Davison Coulee & 100500041503 & $91 \%$ & $4 \%$ & $5 \%$ & $0 \%$ & $0 \%$ & $86 \%$ & $14 \%$ \\
\hline Exeter Creek & 100500041504 & $88 \%$ & $7 \%$ & $4 \%$ & $0 \%$ & $0 \%$ & $73 \%$ & $27 \%$ \\
\hline Milk River-Dodson North Canal & 100500041505 & $66 \%$ & $4 \%$ & $30 \%$ & $0 \%$ & $0 \%$ & $88 \%$ & $12 \%$ \\
\hline Upper Alkali Creek & 100500041601 & $75 \%$ & $5 \%$ & $20 \%$ & $0 \%$ & $26 \%$ & $86 \%$ & $14 \%$ \\
\hline West Alkali Creek & 100500041602 & $74 \%$ & $2 \%$ & $24 \%$ & $0 \%$ & $30 \%$ & $67 \%$ & $33 \%$ \\
\hline Halfway Coulee & 100500041603 & $80 \%$ & $0 \%$ & $20 \%$ & $0 \%$ & $0 \%$ & $59 \%$ & $41 \%$ \\
\hline Middle Alkali Creek & 100500041604 & $84 \%$ & $13 \%$ & $3 \%$ & $0 \%$ & $85 \%$ & $81 \%$ & $19 \%$ \\
\hline Lower Alkali Creek & 100500041605 & $77 \%$ & $2 \%$ & $21 \%$ & $0 \%$ & $57 \%$ & $86 \%$ & $14 \%$ \\
\hline Upper Assiniboine Creek & 100500041701 & $93 \%$ & $6 \%$ & $1 \%$ & $0 \%$ & $0 \%$ & $82 \%$ & $18 \%$ \\
\hline Middle Assiniboine Creek & 100500041702 & $86 \%$ & $7 \%$ & $7 \%$ & $0 \%$ & $0 \%$ & $85 \%$ & $15 \%$ \\
\hline Lower Assiniboine Creek & 100500041703 & $62 \%$ & $5 \%$ & $33 \%$ & $0 \%$ & $26 \%$ & $65 \%$ & $35 \%$ \\
\hline Martin Lake & 100500041801 & $58 \%$ & $7 \%$ & $33 \%$ & $1 \%$ & $79 \%$ & $90 \%$ & $10 \%$ \\
\hline 100500041802 & 100500041802 & $90 \%$ & $8 \%$ & $0 \%$ & $2 \%$ & $0 \%$ & $66 \%$ & $34 \%$ \\
\hline Austin Coulee & 100500041803 & $88 \%$ & $4 \%$ & $2 \%$ & $6 \%$ & $10 \%$ & $87 \%$ & $13 \%$ \\
\hline Little Cottonwood Creek & 100500041804 & $86 \%$ & $2 \%$ & $10 \%$ & $2 \%$ & $100 \%$ & $83 \%$ & $17 \%$ \\
\hline Milk River-Malta & 100500041901 & $90 \%$ & $2 \%$ & $7 \%$ & $1 \%$ & $0 \%$ & $80 \%$ & $20 \%$ \\
\hline Milk River-Horse Camp Coulee & 100500041902 & $51 \%$ & $1 \%$ & $48 \%$ & $0 \%$ & $7 \%$ & $92 \%$ & $8 \%$ \\
\hline Martins Coulee & 100500041903 & $51 \%$ & $7 \%$ & $34 \%$ & $8 \%$ & $51 \%$ & $66 \%$ & $34 \%$ \\
\hline $\begin{array}{l}\text { Milk River- } \\
\text { Little Cottonwood Creek }\end{array}$ & 100500041904 & $94 \%$ & $0 \%$ & $6 \%$ & $0 \%$ & $49 \%$ & $97 \%$ & $3 \%$ \\
\hline Milk River-Hewitt Lake & 100500041905 & $77 \%$ & $4 \%$ & $19 \%$ & $0 \%$ & $96 \%$ & $59 \%$ & $41 \%$ \\
\hline Upper Stinky Creek & 100500042001 & $70 \%$ & $16 \%$ & $15 \%$ & $0 \%$ & $80 \%$ & $58 \%$ & $42 \%$ \\
\hline Eask Fork Stinky Creek & 100500042002 & $77 \%$ & $1 \%$ & $22 \%$ & $0 \%$ & $28 \%$ & $62 \%$ & $38 \%$ \\
\hline Lower Stinky Creek & 100500042003 & $87 \%$ & $11 \%$ & $2 \%$ & $0 \%$ & $50 \%$ & $74 \%$ & $26 \%$ \\
\hline Milk River-Dry Stinky Creek & 100500042101 & $92 \%$ & $7 \%$ & $1 \%$ & $0 \%$ & $13 \%$ & $91 \%$ & $9 \%$ \\
\hline Milk River-Snieder Coulee & 100500042102 & $98 \%$ & $1 \%$ & $1 \%$ & $0 \%$ & $11 \%$ & $95 \%$ & $5 \%$ \\
\hline Twelvemile Coulee & 100500050101 & $100 \%$ & $0 \%$ & $0 \%$ & $0 \%$ & $92 \%$ & $64 \%$ & $36 \%$ \\
\hline Upper Sixmile Coulee & 100500050102 & $93 \%$ & $7 \%$ & $0 \%$ & $0 \%$ & $44 \%$ & $63 \%$ & $37 \%$ \\
\hline Lower Sixmile Coulee & 100500050103 & $93 \%$ & $7 \%$ & $0 \%$ & $0 \%$ & $78 \%$ & $97 \%$ & $3 \%$ \\
\hline Fourteenmile Coulee & 100500050104 & $96 \%$ & $4 \%$ & $0 \%$ & $0 \%$ & $9 \%$ & $95 \%$ & $5 \%$ \\
\hline Twelvemile Coulee & 100500050105 & $97 \%$ & $3 \%$ & $0 \%$ & $0 \%$ & $36 \%$ & $90 \%$ & $10 \%$ \\
\hline Lonesome Lake & 100500050106 & $99 \%$ & $0 \%$ & $1 \%$ & $0 \%$ & $3 \%$ & $96 \%$ & $4 \%$ \\
\hline Muddy Creek & 100500050201 & $0 \%$ & $0 \%$ & $0 \%$ & $100 \%$ & $13 \%$ & $96 \%$ & $4 \%$ \\
\hline Big Sandy Creek-Godfrey Creek & 100500050202 & $85 \%$ & $6 \%$ & $0 \%$ & $9 \%$ & $17 \%$ & $88 \%$ & $12 \%$ \\
\hline Big Sandy Creek-Rattlesnake Butte & 100500050203 & $84 \%$ & $16 \%$ & $0 \%$ & $0 \%$ & $5 \%$ & $83 \%$ & $17 \%$ \\
\hline Gorman Creek & 100500050204 & $88 \%$ & $3 \%$ & $0 \%$ & $9 \%$ & $78 \%$ & $79 \%$ & $21 \%$ \\
\hline Big Sandy Creek- & 100500050301 & $47 \%$ & $22 \%$ & $31 \%$ & $0 \%$ & $5 \%$ & $75 \%$ & $25 \%$ \\
\hline
\end{tabular}


Wetland Landscape Profiling of Palustrine Wetlands: Sixth-Code Hydrological Unit

\begin{tabular}{|c|c|c|c|c|c|c|c|c|}
\hline 6th Code HUC Name & HUC Number & Private & State & Federal & Tribal & Protected & Natural & Altered \\
\hline Duck Creek & 100500050302 & $66 \%$ & $1 \%$ & $0 \%$ & $34 \%$ & $1 \%$ & $30 \%$ & $70 \%$ \\
\hline Boxelder Creek & 100500050303 & $20 \%$ & $0 \%$ & $0 \%$ & $80 \%$ & $41 \%$ & $86 \%$ & $14 \%$ \\
\hline Big Sandy Creek-Barneys Coulee & 100500050304 & $97 \%$ & $2 \%$ & $0 \%$ & $1 \%$ & $19 \%$ & $75 \%$ & $25 \%$ \\
\hline Big Sandy Creek-Schwartz Creek & 100500050401 & $52 \%$ & $1 \%$ & $0 \%$ & $47 \%$ & $12 \%$ & $34 \%$ & $66 \%$ \\
\hline Gravel Coulee & 100500050402 & $23 \%$ & $1 \%$ & $0 \%$ & $76 \%$ & $10 \%$ & $29 \%$ & $71 \%$ \\
\hline Spring Coulee & 100500050403 & $99 \%$ & $0 \%$ & $0 \%$ & $1 \%$ & $80 \%$ & $33 \%$ & $67 \%$ \\
\hline Sprinkle Coulee & 100500050404 & $89 \%$ & $11 \%$ & $0 \%$ & $0 \%$ & $97 \%$ & $58 \%$ & $42 \%$ \\
\hline Big Sandy Creek-Antelope Coulee & 100500050405 & $99 \%$ & $1 \%$ & $0 \%$ & $0 \%$ & $55 \%$ & $71 \%$ & $29 \%$ \\
\hline Laird Creek & 100500060101 & $91 \%$ & $7 \%$ & $2 \%$ & $0 \%$ & $2 \%$ & $68 \%$ & $32 \%$ \\
\hline Headwaters of Sage Creek & 100500060102 & $94 \%$ & $6 \%$ & $0 \%$ & $0 \%$ & $21 \%$ & $83 \%$ & $17 \%$ \\
\hline age Creek-Lost Coulee & 100500060103 & $90 \%$ & $10 \%$ & $0 \%$ & $0 \%$ & $92 \%$ & $70 \%$ & $30 \%$ \\
\hline Sage Creek-Immanuel Church & 100500060104 & $94 \%$ & $6 \%$ & $0 \%$ & $0 \%$ & $1 \%$ & $56 \%$ & $44 \%$ \\
\hline Sage Creek-Strode & 100500060105 & $94 \%$ & $6 \%$ & $0 \%$ & $0 \%$ & $0 \%$ & $38 \%$ & $62 \%$ \\
\hline _aird Lake & 100500060106 & $98 \%$ & $2 \%$ & $0 \%$ & $0 \%$ & $100 \%$ & $68 \%$ & $32 \%$ \\
\hline Rudyard Road & 100500060107 & $99 \%$ & $1 \%$ & $0 \%$ & $0 \%$ & $3 \%$ & $60 \%$ & $40 \%$ \\
\hline Oreana School & 100500060108 & $100 \%$ & $0 \%$ & $0 \%$ & $0 \%$ & $11 \%$ & $83 \%$ & $17 \%$ \\
\hline Sage Creek-Mckinnsey Reservoir & 100500060109 & $96 \%$ & $4 \%$ & $0 \%$ & $0 \%$ & $92 \%$ & $65 \%$ & $35 \%$ \\
\hline Upper Little Sage Creek & 100500060201 & $87 \%$ & $13 \%$ & $0 \%$ & $0 \%$ & $50 \%$ & $84 \%$ & $16 \%$ \\
\hline Varer Reservoir & 100500060202 & $99 \%$ & $1 \%$ & $0 \%$ & $0 \%$ & $77 \%$ & $65 \%$ & $35 \%$ \\
\hline Big Coulee & 100500060203 & $89 \%$ & $11 \%$ & $0 \%$ & $0 \%$ & $58 \%$ & $88 \%$ & $12 \%$ \\
\hline Lower Little Sage Creek & 100500060204 & $82 \%$ & $18 \%$ & $0 \%$ & $0 \%$ & $20 \%$ & $72 \%$ & $28 \%$ \\
\hline Fourmile Coulee & 100500060301 & $90 \%$ & $10 \%$ & $0 \%$ & $0 \%$ & $57 \%$ & $79 \%$ & $21 \%$ \\
\hline Upper O’Brien Coulee & 100500060302 & $95 \%$ & $5 \%$ & $0 \%$ & $0 \%$ & $100 \%$ & $34 \%$ & $66 \%$ \\
\hline Lower O'Brien Coulee & 100500060303 & $100 \%$ & $0 \%$ & $0 \%$ & $0 \%$ & $61 \%$ & $84 \%$ & $16 \%$ \\
\hline Middle O'Brien Coulee & 100500060304 & $91 \%$ & $9 \%$ & $0 \%$ & $0 \%$ & $40 \%$ & $85 \%$ & $15 \%$ \\
\hline ingham Coulee & 100500060401 & $82 \%$ & $18 \%$ & $0 \%$ & $0 \%$ & $0 \%$ & $46 \%$ & $54 \%$ \\
\hline Upper England Coulee & 100500060402 & $100 \%$ & $0 \%$ & $0 \%$ & $0 \%$ & $8 \%$ & $97 \%$ & $3 \%$ \\
\hline Lower England Coulee & 100500060403 & $94 \%$ & $6 \%$ & $0 \%$ & $0 \%$ & $3 \%$ & $86 \%$ & $14 \%$ \\
\hline $\begin{array}{l}\text { Sage Creek- } \\
\text { Burkhartsmeyer Reservoir }\end{array}$ & 10050006 & $96 \%$ & $4 \%$ & $0 \%$ & $0 \%$ & $100^{\circ}$ & $41 \%$ & $59 \%$ \\
\hline aulkners Coulee & 100500060502 & $93 \%$ & $7 \%$ & $0 \%$ & $0 \%$ & $8 \%$ & $80 \%$ & $20 \%$ \\
\hline age Creek-Sage Lake & 100500060503 & $80 \%$ & $20 \%$ & $0 \%$ & $0 \%$ & $53 \%$ & $70 \%$ & $30 \%$ \\
\hline ailey Reservoir & 100500060504 & $100 \%$ & $0 \%$ & $0 \%$ & $0 \%$ & $83 \%$ & $48 \%$ & $52 \%$ \\
\hline alfway Coulee & 100500060505 & $90 \%$ & $10 \%$ & $0 \%$ & $0 \%$ & $16 \%$ & $93 \%$ & $7 \%$ \\
\hline Lower Sage Creek & 100500060506 & $97 \%$ & $3 \%$ & $0 \%$ & $0 \%$ & $41 \%$ & $78 \%$ & $22 \%$ \\
\hline Creedman Coulee & 100500070101 & $97 \%$ & $1 \%$ & $3 \%$ & $0 \%$ & $46 \%$ & $57 \%$ & $43 \%$ \\
\hline Upper Lodger Creek & 100500070102 & $91 \%$ & $9 \%$ & $0 \%$ & $0 \%$ & $3 \%$ & $47 \%$ & $53 \%$ \\
\hline Middle Lodge Creek & 100500070103 & $94 \%$ & $4 \%$ & $2 \%$ & $0 \%$ & $0 \%$ & $54 \%$ & $46 \%$ \\
\hline Hay Coulee & 100500070104 & $40 \%$ & $30 \%$ & $30 \%$ & $0 \%$ & $100 \%$ & $50 \%$ & $50 \%$ \\
\hline Lower Lodger Creek & 100500070105 & $87 \%$ & $2 \%$ & $11 \%$ & $0 \%$ & $33 \%$ & $74 \%$ & $26 \%$ \\
\hline Upper East Fork Battle Creek & 100500080101 & $36 \%$ & $39 \%$ & $25 \%$ & $0 \%$ & $15 \%$ & $80 \%$ & $20 \%$ \\
\hline Middle East Fork Battle Creek & 100500080102 & $50 \%$ & $4 \%$ & $46 \%$ & $0 \%$ & $6 \%$ & $22 \%$ & $78 \%$ \\
\hline Lyons Coulee & 100500080103 & $67 \%$ & $1 \%$ & $32 \%$ & $0 \%$ & $13 \%$ & $79 \%$ & $21 \%$ \\
\hline Corral Coulee & 100500080104 & $62 \%$ & $5 \%$ & $33 \%$ & $0 \%$ & $29 \%$ & $58 \%$ & $42 \%$ \\
\hline 100500080105 & 100500080105 & $54 \%$ & $2 \%$ & $44 \%$ & $0 \%$ & $80 \%$ & $29 \%$ & $71 \%$ \\
\hline Lower East Fork Battle Creek & 100500080106 & $66 \%$ & $2 \%$ & $32 \%$ & $0 \%$ & $0 \%$ & $55 \%$ & $45 \%$ \\
\hline Upper Battle Creek & 100500080201 & $66 \%$ & $15 \%$ & $19 \%$ & $0 \%$ & $93 \%$ & $47 \%$ & $53 \%$ \\
\hline Middle Battle Creek & 100500080202 & $84 \%$ & $0 \%$ & $16 \%$ & $0 \%$ & $1 \%$ & $20 \%$ & $80 \%$ \\
\hline Chouteau Creek & 100500080203 & $68 \%$ & $3 \%$ & $28 \%$ & $1 \%$ & $91 \%$ & $58 \%$ & $42 \%$ \\
\hline Dry Fork Battle Creek & 100500080204 & $74 \%$ & $9 \%$ & $16 \%$ & $0 \%$ & $62 \%$ & $66 \%$ & $34 \%$ \\
\hline Coal Creek & 100500080205 & $82 \%$ & $3 \%$ & $16 \%$ & $0 \%$ & $0 \%$ & $60 \%$ & $40 \%$ \\
\hline Lower Battle Creek & 100500080206 & $94 \%$ & $5 \%$ & $2 \%$ & $0 \%$ & $61 \%$ & $47 \%$ & $53 \%$ \\
\hline
\end{tabular}


Wetland Landscape Profiling of Palustrine Wetlands: Sixth-Code Hydrological Unit 6th Code HUC Name HUC Number Private State Federal Tribal Protected Natural Altered

\begin{tabular}{|c|c|c|c|c|c|c|c|c|}
\hline$\overline{\text { Duck Creek }}$ & 100500090101 & $18 \%$ & $0 \%$ & $0 \%$ & $82 \%$ & $58 \%$ & $74 \%$ & $26 \%$ \\
\hline Little Peoples Creek & 100500090102 & $0 \%$ & $0 \%$ & $2 \%$ & $98 \%$ & $31 \%$ & $84 \%$ & $16 \%$ \\
\hline Jim Brown Creek & 100500090103 & $0 \%$ & $0 \%$ & $0 \%$ & $100 \%$ & $94 \%$ & $84 \%$ & $16 \%$ \\
\hline Lodge Pole Creek & 100500090104 & $0 \%$ & $0 \%$ & $0 \%$ & $100 \%$ & $88 \%$ & $75 \%$ & $25 \%$ \\
\hline South Fork Peoples Creek & 100500090105 & $0 \%$ & $0 \%$ & $0 \%$ & $100 \%$ & $0 \%$ & $83 \%$ & $17 \%$ \\
\hline $\begin{array}{l}\text { Peoples Creek- } \\
\quad \text { South Branch Peoples Creek }\end{array}$ & 100500090201 & $80 \%$ & $20 \%$ & $0 \%$ & $0 \%$ & $51 \%$ & $76 \%$ & $24 \%$ \\
\hline $\begin{array}{l}\text { Peoples Creek- } \\
\text { Nicholson Bluff Creek }\end{array}$ & 100500090202 & $95 \%$ & $5 \%$ & $0 \%$ & $0 \%$ & $25 \%$ & $64 \%$ & $36 \%$ \\
\hline Peoples Creek-Maggie Creek & 100500090203 & $51 \%$ & $49 \%$ & $0 \%$ & $0 \%$ & $35 \%$ & $90 \%$ & $10 \%$ \\
\hline Peoples Creek-Saint Johns Coulee & 100500090204 & $5 \%$ & $16 \%$ & $0 \%$ & $79 \%$ & $3 \%$ & $90 \%$ & $10 \%$ \\
\hline Fogarty Coulee & 100500090205 & $31 \%$ & $11 \%$ & $0 \%$ & $58 \%$ & $0 \%$ & $73 \%$ & $27 \%$ \\
\hline Peoples Creek-Wildhorse Butte & 100500090206 & $0 \%$ & $0 \%$ & $0 \%$ & $100 \%$ & $100 \%$ & $82 \%$ & $18 \%$ \\
\hline Upper Lone Tree Coulee & 100500090301 & $0 \%$ & $0 \%$ & $0 \%$ & $100 \%$ & $0 \%$ & $95 \%$ & $5 \%$ \\
\hline Lower Lone Tree Coulee & 100500090302 & $10 \%$ & $0 \%$ & $0 \%$ & $90 \%$ & $45 \%$ & $43 \%$ & $57 \%$ \\
\hline Mud Creek & 100500090401 & $0 \%$ & $0 \%$ & $0 \%$ & $100 \%$ & $7 \%$ & $56 \%$ & $44 \%$ \\
\hline Peoples Creek-Corral Coulee & 100500090402 & $65 \%$ & $0 \%$ & $9 \%$ & $25 \%$ & $42 \%$ & $94 \%$ & $6 \%$ \\
\hline Peoples Creek-Willow Coulee & 100500090403 & $0 \%$ & $0 \%$ & $0 \%$ & $100 \%$ & $0 \%$ & $82 \%$ & $18 \%$ \\
\hline Upper Murray Coulee & 100500100101 & $96 \%$ & $3 \%$ & $0 \%$ & $1 \%$ & $100 \%$ & $98 \%$ & $2 \%$ \\
\hline Lower Murray Coulee & 100500100102 & $97 \%$ & $3 \%$ & $0 \%$ & $0 \%$ & $4 \%$ & $100 \%$ & $0 \%$ \\
\hline Turner & 100500100201 & $95 \%$ & $5 \%$ & $0 \%$ & $0 \%$ & $96 \%$ & $100 \%$ & $0 \%$ \\
\hline Buckley Creek & 100500100202 & $95 \%$ & $5 \%$ & $0 \%$ & $0 \%$ & $89 \%$ & $100 \%$ & $0 \%$ \\
\hline $\begin{array}{l}\text { Woody Island Coulee- } \\
\text { Silverbow Lake }\end{array}$ & 100500100301 & $91 \%$ & $2 \%$ & $2 \%$ & $4 \%$ & $65 \%$ & $95 \%$ & $5 \%$ \\
\hline $\begin{array}{l}\text { Woody Island Coulee- } \\
100500100302\end{array}$ & 100500100302 & $84 \%$ & $5 \%$ & $0 \%$ & $11 \%$ & $100 \%$ & $96 \%$ & $4 \%$ \\
\hline Woody Island Coulee-Alkali Lake & 100500100303 & $87 \%$ & $1 \%$ & $8 \%$ & $4 \%$ & $67 \%$ & $99 \%$ & $1 \%$ \\
\hline Middle Woody Island Coulee & 100500100304 & $37 \%$ & $3 \%$ & $59 \%$ & $0 \%$ & $100 \%$ & $99 \%$ & $1 \%$ \\
\hline $\begin{array}{l}\text { Woody Island Coulee- } \\
\text { Buckley Creek }\end{array}$ & 100500100305 & $90 \%$ & $3 \%$ & $7 \%$ & $0 \%$ & $2 \%$ & $93 \%$ & $7 \%$ \\
\hline Woody Island Coulee-Big Butte & 100500100306 & $74 \%$ & $3 \%$ & $23 \%$ & $0 \%$ & $36 \%$ & $99 \%$ & $1 \%$ \\
\hline $\begin{array}{l}\text { Woody Island Coulee- } \\
100500100307\end{array}$ & 100500100307 & $82 \%$ & $3 \%$ & $16 \%$ & $0 \%$ & $21 \%$ & $98 \%$ & $2 \%$ \\
\hline Lower Woody Island Coulee & 100500100308 & $65 \%$ & $6 \%$ & $29 \%$ & $0 \%$ & $4 \%$ & $91 \%$ & $9 \%$ \\
\hline Little Jewel Coulee & 100500100401 & $78 \%$ & $6 \%$ & $16 \%$ & $0 \%$ & $99 \%$ & $93 \%$ & $7 \%$ \\
\hline Coburg Coulee & 100500100402 & $62 \%$ & $1 \%$ & $37 \%$ & $0 \%$ & $35 \%$ & $80 \%$ & $20 \%$ \\
\hline Black Coulee & 100500100403 & $67 \%$ & $1 \%$ & $31 \%$ & $0 \%$ & $29 \%$ & $92 \%$ & $8 \%$ \\
\hline Headwaters Cottonwood Creek & 100500100501 & $33 \%$ & $9 \%$ & $58 \%$ & $0 \%$ & $24 \%$ & $86 \%$ & $14 \%$ \\
\hline Upper Cottonwood Creek & 100500100502 & $71 \%$ & $2 \%$ & $27 \%$ & $0 \%$ & $100 \%$ & $89 \%$ & $11 \%$ \\
\hline Middle Cottonwood Creek & 100500100503 & $87 \%$ & $2 \%$ & $12 \%$ & $0 \%$ & $9 \%$ & $91 \%$ & $9 \%$ \\
\hline Lambing Coulee & 100500100504 & $27 \%$ & $13 \%$ & $60 \%$ & $1 \%$ & $59 \%$ & $65 \%$ & $35 \%$ \\
\hline Lower Cottonwood Creek & 100500100505 & $82 \%$ & $4 \%$ & $14 \%$ & $0 \%$ & $20 \%$ & $88 \%$ & $12 \%$ \\
\hline Garland Creek & 100500100506 & $71 \%$ & $17 \%$ & $13 \%$ & $0 \%$ & $70 \%$ & $87 \%$ & $13 \%$ \\
\hline Pea Lake & 100500110101 & $20 \%$ & $1 \%$ & $80 \%$ & $0 \%$ & $11 \%$ & $92 \%$ & $8 \%$ \\
\hline Lester Reservoir & 100500110102 & $62 \%$ & $14 \%$ & $24 \%$ & $0 \%$ & $57 \%$ & $89 \%$ & $11 \%$ \\
\hline Upper East Fork Whitewater Creek & 100500110103 & $58 \%$ & $10 \%$ & $32 \%$ & $0 \%$ & $99 \%$ & $83 \%$ & $17 \%$ \\
\hline Lower East Fork Whitewater Creek & 100500110104 & $61 \%$ & $6 \%$ & $31 \%$ & $2 \%$ & $80 \%$ & $95 \%$ & $5 \%$ \\
\hline 100500110201 & 100500110201 & $62 \%$ & $4 \%$ & $35 \%$ & $0 \%$ & $5 \%$ & $96 \%$ & $4 \%$ \\
\hline Headwaters Cottonwood Coulee & 100500110202 & $70 \%$ & $3 \%$ & $26 \%$ & $1 \%$ & $3 \%$ & $97 \%$ & $3 \%$ \\
\hline Whitewater Creek- & 100500110203 & $24 \%$ & $3 \%$ & $71 \%$ & $3 \%$ & $100 \%$ & $94 \%$ & $6 \%$ \\
\hline
\end{tabular}


Wetland Landscape Profiling of Palustrine Wetlands: Sixth-Code Hydrological Unit

\section{6th Code HUC Name}

Whitewater Creek-

Lone Tree Coulee

Dibble Creek

Whitewater Creek-Austin Lake

Whitewater Creek-Clark Coulee

Whitewater Creek-Hymer Coulee

Lime Creek

Bear Creek

Upper Buggy Creek

Canyon Creek

Lower Buggy Creek

Hardscrabble Creek

Upper Antelope Creek

Lower Antelope Creek

Milk River-Hinsdale

Milk River-Buffalo Coulee

Mooney Coulee

Milk River-Tampico

Upper Brazil Creek

Lower Brazil Creek

Upper Cherry Creek

Upper East Fork Cherry Creek

Lower East Fork Cherry Creek

Lower Cherry Creek

South Fork Lone Tree Creek

North Fork Lone Tree Creek

Lone Tree Creek

Upper Little Beaver Creek

Middle Little Beaver Creek

South Fork Little Beaver Creek

Lower Little Beaver Creek

Headwaters Willow Creek

Desert Coulee

Hard Pan Creek

Willow Creek-Collins Reservoir

Willow Creek-Pearson Coulee

Willow Creek-Wilderness Coulee

Willow Creek-Archambeault Flats

Willow Creek-Dry Lake

Milk River-Glasgow

Milk River-Nashua

Milk River Coulee

Lower Milk River

Frenchman Creek-Canada

Frenchman Creek-Peck Coulee

Cottonwood Creek

Corral Coulee

Frenchman Creek-

Frenchman Reservoir

Frenchman Creek-

Panhandle Coulee

Lower Frenchman Creek
HUC Number Private State Federal Tribal Protected Natural Altered

$\begin{array}{llllllll}100500110204 & 39 \% & 3 \% & 58 \% & 0 \% & 2 \% & 94 \% & 6 \%\end{array}$

100500110205

100500110206

100500110207

100500110208

100500120101

100500120102

100500120201

100500120202

100500120203

100500120301

100500120302

100500120303

100500120401

100500120402

100500120403

100500120404

100500120501

100500120502

100500120601

100500120602

100500120603

100500120604

100500120701

100500120702

100500120703

100500120801

100500120802

100500120803

100500120804

100500120901

100500120902

100500120903

100500120904

100500120905

100500120906

100500120907

100500120908

100500121001

100500121002

100500121003

100500121004

100500130101

100500130102

100500130103

100500130104

100500130105

$59 \% \quad 1 \% \quad 39 \%$

$75 \% \quad 2 \%$

$75 \% \quad 1 \% \quad 23 \%$

$78 \% \quad 3 \% \quad 19 \%$

$80 \% \quad 3 \% \quad 18 \%$

$87 \% \quad 1 \% \quad 11 \%$

$26 \% \quad 40 \% \quad 34 \%$

$30 \% \quad 0 \% \quad 70 \%$

$59 \% \quad 32 \% \quad 9 \%$

$92 \% \quad 0 \% \quad 8 \%$

$46 \% \quad 9 \% \quad 44 \%$

$86 \% \quad 1 \% \quad 13 \%$

$97 \% \quad 2 \% \quad 1 \%$

$97 \% \quad 0 \% \quad 3 \%$

$41 \% \quad 0 \% \quad 59 \%$

$80 \% \quad 16 \% \quad 4 \%$

$9 \% \quad 3 \% \quad 88 \%$

$84 \% \quad 1 \% \quad 14 \%$

$31 \% \quad 64 \% \quad 5 \%$

$75 \%$

$2 \% \quad 23 \%$

$76 \% \quad 14 \% \quad 10 \%$

$88 \% \quad 1 \% \quad 11 \%$

$68 \% \quad 0 \% \quad 32 \%$

$0 \% \quad 0 \% \quad 100 \%$

$26 \% \quad 4 \% \quad 71 \%$

$0 \% \quad 0 \% \quad 100 \%$

$0 \% \quad 6 \% \quad 94 \%$

$5 \% \quad 0 \% \quad 95 \%$

$0 \% \quad 8 \% \quad 92 \%$

$2 \% \quad 11 \% \quad 87 \%$

$84 \% \quad 0 \% \quad 16 \%$

$0 \% \quad 0 \% \quad 100 \%$

$25 \% \quad 8 \%$

$11 \% \quad 0 \%$

$67 \%$

$89 \%$

$0 \% \quad 0 \%$

$15 \% \quad 0 \%$

$94 \% \quad 3 \%$

$100 \% \quad 0 \%$

$98 \% \quad 2 \%$

$0 \% \quad 0 \%$

$7 \% \quad 0 \%$

$74 \% \quad 3 \% \quad 23 \%$

$67 \% \quad 20 \% \quad 14 \%$

$41 \% \quad 11 \% \quad 49 \%$

$77 \% \quad 0 \% \quad 23 \%$

$93 \% \quad 3 \% \quad 4 \%$

100500130106

$95 \% \quad 4 \% \quad 1 \%$

100500130107
$2 \%$

$1 \% \quad 18 \%$

$0 \% \quad 18 \%$

$0 \% \quad 24 \%$

$0 \%$

$0 \%$

$0 \%$

$0 \%$

$0 \%$

$0 \%$

$0 \%$

$0 \%$

$0 \%$

$0 \%$

$0 \%$

$0 \%$

$0 \%$

$0 \%$

$0 \%$

$0 \%$

$0 \%$

$0 \%$

$0 \%$

$0 \%$

$0 \%$

$0 \%$

$0 \%$

$0 \%$

$0 \%$

$0 \%$

$0 \%$

$0 \%$

$0 \%$

$0 \%$

$0 \%$
$0 \%$

$0 \%$
$0 \%$

$0 \%$

$0 \%$

$100 \%$

$93 \%$

$0 \% \quad 38 \%$

$0 \% \quad 0 \%$

$0 \%$

$0 \%$

$0 \%$

$75 \%$

$1 \% \quad 19 \%$

$90 \%$
$2 \% \quad 14 \%$

$0 \% \quad 3 \%$

$93 \% \quad 7 \%$

$92 \% \quad 8 \%$

$88 \% \quad 12 \%$

$90 \% \quad 10 \%$

$30 \% \quad 70 \%$

$72 \% \quad 28 \%$

$56 \% \quad 44 \%$

$20 \% \quad 80 \%$

$31 \% \quad 69 \%$

$20 \% \quad 80 \%$

$20 \% \quad 80 \%$

$28 \% \quad 72 \%$

$86 \% \quad 14 \%$

$54 \% \quad 46 \%$

$42 \% \quad 58 \%$

$89 \% \quad 11 \%$

$20 \% \quad 80 \%$

$0 \% \quad 100 \%$

$68 \% \quad 32 \%$

$45 \% \quad 55 \%$

$49 \% \quad 51 \%$

$74 \% \quad 26 \%$

$100 \% \quad 0 \% \quad 100 \%$

$0 \% \quad 5 \% \quad 95 \%$

$100 \% \quad 8 \% \quad 92 \%$

$100 \% \quad 4 \% \quad 96 \%$

$\begin{array}{lll}9 \% & 3 \% & 97 \%\end{array}$

$1 \% \quad 99 \%$

$2 \% \quad 98 \%$

$7 \% \quad 93 \%$

$0 \% \quad 100 \%$

$0 \% \quad 100 \%$

$0 \% \quad 100 \%$

$1 \% \quad 99 \%$

$89 \% \quad 11 \%$

$77 \% \quad 23 \%$

$96 \% \quad 4 \%$

$95 \% \quad 5 \%$

$93 \% \quad 7 \%$

$85 \% \quad 15 \%$

$85 \% \quad 15 \%$

$52 \% \quad 48 \%$

$61 \% \quad 39 \%$

$78 \% \quad 22 \%$

$71 \% \quad 29 \%$

$88 \% \quad 11 \% \quad 0 \%$

Appendix I - 17 
Wetland Landscape Profiling of Palustrine Wetlands: Sixth-Code Hydrological Unit 6th Code HUC Name HUC Number Private State Federal Tribal Prot

\begin{tabular}{|c|c|c|c|c|c|c|c|c|}
\hline Upper Big Warm Creek & 100500140101 & $12 \%$ & $0 \%$ & $3 \%$ & $85 \%$ & $100 \%$ & $65 \%$ & $35 \%$ \\
\hline Middle Big Warm Creek & 100500140102 & $72 \%$ & $0 \%$ & $7 \%$ & $21 \%$ & $100 \%$ & $45 \%$ & $55 \%$ \\
\hline Little Warm Creek & 100500140103 & $76 \%$ & $10 \%$ & $7 \%$ & $8 \%$ & $6 \%$ & $74 \%$ & $26 \%$ \\
\hline Chicken Coulee & 100500140104 & $8 \%$ & $0 \%$ & $0 \%$ & $92 \%$ & $0 \%$ & $72 \%$ & $28 \%$ \\
\hline Tressler Coulee & 100500140105 & $86 \%$ & $6 \%$ & $6 \%$ & $2 \%$ & $21 \%$ & $78 \%$ & $22 \%$ \\
\hline Wild Horse Creek & 100500140106 & $80 \%$ & $1 \%$ & $8 \%$ & $11 \%$ & $96 \%$ & $49 \%$ & $51 \%$ \\
\hline White Rock Coulee & 100500140107 & $58 \%$ & $3 \%$ & $39 \%$ & $0 \%$ & $5 \%$ & $57 \%$ & $43 \%$ \\
\hline Lower Big Warm Creek & 100500140108 & $56 \%$ & $7 \%$ & $37 \%$ & $0 \%$ & $0 \%$ & $76 \%$ & $24 \%$ \\
\hline Beaver Creek-Bear Gulch & 100500140201 & $32 \%$ & $17 \%$ & $1 \%$ & $51 \%$ & $5 \%$ & $47 \%$ & $53 \%$ \\
\hline Beaver Creek-Coburn Butte & 100500140202 & $51 \%$ & $1 \%$ & $48 \%$ & $0 \%$ & $0 \%$ & $60 \%$ & $40 \%$ \\
\hline Veseth Reservoir & 100500140203 & $62 \%$ & $1 \%$ & $37 \%$ & $0 \%$ & $21 \%$ & $23 \%$ & $77 \%$ \\
\hline Beaver Creek-Holzhey Reservoir & 100500140204 & $48 \%$ & $2 \%$ & $50 \%$ & $0 \%$ & $12 \%$ & $59 \%$ & $41 \%$ \\
\hline Beaver Creek-100500140205 & 100500140205 & $84 \%$ & $4 \%$ & $12 \%$ & $0 \%$ & $51 \%$ & $77 \%$ & $23 \%$ \\
\hline Beaver Creek-Nelson Coulee & 100500140206 & $76 \%$ & $4 \%$ & $20 \%$ & $0 \%$ & $6 \%$ & $86 \%$ & $14 \%$ \\
\hline Beaver Creek-Horse Pasture Coulee & e100500140207 & $53 \%$ & $7 \%$ & $40 \%$ & $0 \%$ & $63 \%$ & $80 \%$ & $20 \%$ \\
\hline First Creek & 100500140301 & $47 \%$ & $7 \%$ & $46 \%$ & $0 \%$ & $59 \%$ & $52 \%$ & $48 \%$ \\
\hline Sun Prairie Flats & 100500140302 & $79 \%$ & $2 \%$ & $20 \%$ & $0 \%$ & $9 \%$ & $65 \%$ & $35 \%$ \\
\hline Sheep Coulee & 100500140303 & $56 \%$ & $1 \%$ & $43 \%$ & $0 \%$ & $0 \%$ & $64 \%$ & $36 \%$ \\
\hline Flat Creek & 100500140304 & $92 \%$ & $0 \%$ & $8 \%$ & $0 \%$ & $100 \%$ & $88 \%$ & $12 \%$ \\
\hline Sage Creek & 100500140305 & $74 \%$ & $7 \%$ & $19 \%$ & $0 \%$ & $19 \%$ & $0 \%$ & $100 \%$ \\
\hline Little Sevenmile Creek & 100500140306 & $65 \%$ & $1 \%$ & $34 \%$ & $0 \%$ & $67 \%$ & $85 \%$ & $15 \%$ \\
\hline Tallow Creek & 100500140307 & $86 \%$ & $0 \%$ & $14 \%$ & $0 \%$ & $93 \%$ & $0 \%$ & $100 \%$ \\
\hline Spring Creek & 100500140308 & $40 \%$ & $6 \%$ & $54 \%$ & $0 \%$ & $0 \%$ & $19 \%$ & $81 \%$ \\
\hline Flat Creek & 100500140309 & $83 \%$ & $0 \%$ & $16 \%$ & $0 \%$ & $97 \%$ & $59 \%$ & $41 \%$ \\
\hline DHS Creek & 100500140401 & $90 \%$ & $5 \%$ & $5 \%$ & $0 \%$ & $54 \%$ & $58 \%$ & $42 \%$ \\
\hline Beaver Creek-Grove Coulee & 100500140402 & $69 \%$ & $1 \%$ & $30 \%$ & $0 \%$ & $97 \%$ & $68 \%$ & $32 \%$ \\
\hline Beaver Creek-Pickhandle & 100500140403 & $76 \%$ & $3 \%$ & $21 \%$ & $0 \%$ & $98 \%$ & $71 \%$ & $29 \%$ \\
\hline Sevenmile Creek & 100500140404 & $98 \%$ & $2 \%$ & $0 \%$ & $0 \%$ & $2 \%$ & $86 \%$ & $14 \%$ \\
\hline Moss Coulee & 100500140405 & $96 \%$ & $0 \%$ & $3 \%$ & $0 \%$ & $4 \%$ & $65 \%$ & $35 \%$ \\
\hline Beaver Creek-Guston Coulee & 100500140406 & $77 \%$ & $8 \%$ & $15 \%$ & $0 \%$ & $100 \%$ & $92 \%$ & $8 \%$ \\
\hline Beaver Creek-Lenoir Coulee & 100500140407 & $89 \%$ & $4 \%$ & $7 \%$ & $0 \%$ & $0 \%$ & $74 \%$ & $26 \%$ \\
\hline Black Coulee & 100500140501 & $36 \%$ & $1 \%$ & $62 \%$ & $0 \%$ & $46 \%$ & $81 \%$ & $19 \%$ \\
\hline Lake Bowdion & 100500140502 & $33 \%$ & $2 \%$ & $65 \%$ & $0 \%$ & $77 \%$ & $99 \%$ & $1 \%$ \\
\hline Larb Creek-Ten Trees Creek & 100500140601 & $41 \%$ & $3 \%$ & $55 \%$ & $0 \%$ & $59 \%$ & $29 \%$ & $71 \%$ \\
\hline Larb Creek-Craig Coulee & 100500140602 & $30 \%$ & $6 \%$ & $65 \%$ & $0 \%$ & $74 \%$ & $22 \%$ & $78 \%$ \\
\hline Larb Creek-Grant Coulee & 100500140603 & $19 \%$ & $1 \%$ & $80 \%$ & $0 \%$ & $0 \%$ & $18 \%$ & $82 \%$ \\
\hline Larb Creek-Box Elder Coulee & 100500140604 & $53 \%$ & $0 \%$ & $47 \%$ & $0 \%$ & $23 \%$ & $54 \%$ & $46 \%$ \\
\hline Larb Creek-Whites Coulee & 100500140605 & $46 \%$ & $0 \%$ & $54 \%$ & $0 \%$ & $11 \%$ & $54 \%$ & $46 \%$ \\
\hline Larb Creek-Lost Coulee & 100500140606 & $71 \%$ & $6 \%$ & $23 \%$ & $0 \%$ & $4 \%$ & $42 \%$ & $58 \%$ \\
\hline Square Creek & 100500140607 & $82 \%$ & $0 \%$ & $18 \%$ & $0 \%$ & $32 \%$ & $26 \%$ & $74 \%$ \\
\hline Fourth Creek & 100500140608 & $88 \%$ & $1 \%$ & $11 \%$ & $0 \%$ & $0 \%$ & $8 \%$ & $92 \%$ \\
\hline McNab Coulee & 100500140609 & $66 \%$ & $0 \%$ & $34 \%$ & $0 \%$ & $20 \%$ & $41 \%$ & $59 \%$ \\
\hline Second Creek & 100500140610 & $52 \%$ & $0 \%$ & $48 \%$ & $0 \%$ & $34 \%$ & $32 \%$ & $68 \%$ \\
\hline First Creek & 100500140611 & $66 \%$ & $3 \%$ & $31 \%$ & $0 \%$ & $2 \%$ & $29 \%$ & $71 \%$ \\
\hline Larb Creek-Third Creek & 100500140612 & $93 \%$ & $4 \%$ & $4 \%$ & $0 \%$ & $0 \%$ & $56 \%$ & $44 \%$ \\
\hline Beaver Creek-Gilbertson Coulee & 100500140701 & $95 \%$ & $2 \%$ & $2 \%$ & $0 \%$ & $100 \%$ & $89 \%$ & $11 \%$ \\
\hline Nelson Reservoir & 100500140702 & $63 \%$ & $3 \%$ & $34 \%$ & $0 \%$ & $68 \%$ & $98 \%$ & $2 \%$ \\
\hline Beaver Creek-Hay Coulee & 100500140703 & $58 \%$ & $6 \%$ & $36 \%$ & $0 \%$ & $35 \%$ & $93 \%$ & $7 \%$ \\
\hline Beaver Creek-Nelson South Canal & 100500140704 & $97 \%$ & $1 \%$ & $2 \%$ & $0 \%$ & $0 \%$ & $77 \%$ & $23 \%$ \\
\hline Beaver Creek-Limekiln Coulee & 100500140705 & $94 \%$ & $5 \%$ & $1 \%$ & $0 \%$ & $43 \%$ & $95 \%$ & $5 \%$ \\
\hline Morgan Creek & 100500150101 & $96 \%$ & $0 \%$ & $4 \%$ & $0 \%$ & $0 \%$ & $19 \%$ & $81 \%$ \\
\hline Upper Rock Creek & 100500150102 & $28 \%$ & $0 \%$ & $72 \%$ & $0 \%$ & $58 \%$ & $59 \%$ & $41 \%$ \\
\hline
\end{tabular}


Wetland Landscape Profiling of Palustrine Wetlands: Sixth-Code Hydrological Unit

6th Code HUC Name

\begin{tabular}{|c|c|c|c|c|c|c|c|c|}
\hline North Fork South Creek & 100500150201 & $44 \%$ & $2 \%$ & $54 \%$ & $0 \%$ & $100 \%$ & $14 \%$ & $86 \%$ \\
\hline South Creek & 100500150202 & $30 \%$ & $0 \%$ & $70 \%$ & $0 \%$ & $0 \%$ & $17 \%$ & $83 \%$ \\
\hline East Fork Crow Creek & 100500150301 & $11 \%$ & $12 \%$ & $77 \%$ & $0 \%$ & $54 \%$ & $48 \%$ & $52 \%$ \\
\hline Crow Creek & 100500150302 & $47 \%$ & $4 \%$ & $49 \%$ & $0 \%$ & $74 \%$ & $39 \%$ & $61 \%$ \\
\hline Jack Creek & 100500150401 & $79 \%$ & $1 \%$ & $20 \%$ & $0 \%$ & $45 \%$ & $44 \%$ & $56 \%$ \\
\hline Big Snake Creek & 100500150402 & $58 \%$ & $2 \%$ & $40 \%$ & $0 \%$ & $86 \%$ & $52 \%$ & $48 \%$ \\
\hline Upper Willow Creek & 100500150501 & $65 \%$ & $3 \%$ & $32 \%$ & $0 \%$ & $4 \%$ & $17 \%$ & $83 \%$ \\
\hline Lone Tree Coulee & 100500150502 & $0 \%$ & $2 \%$ & $98 \%$ & $0 \%$ & $4 \%$ & $3 \%$ & $97 \%$ \\
\hline Middle Willow Creek & 100500150503 & $15 \%$ & $15 \%$ & $70 \%$ & $0 \%$ & $19 \%$ & $23 \%$ & $77 \%$ \\
\hline Deep Creek & 100500150504 & $16 \%$ & $11 \%$ & $73 \%$ & $0 \%$ & $0 \%$ & $20 \%$ & $80 \%$ \\
\hline Bitter Creek & 100500150505 & $0 \%$ & $0 \%$ & $100 \%$ & $0 \%$ & $0 \%$ & $23 \%$ & $77 \%$ \\
\hline Chisholm Creek & 100500150506 & $32 \%$ & $2 \%$ & $66 \%$ & $0 \%$ & $1 \%$ & $15 \%$ & $85 \%$ \\
\hline Eagle Creek & 100500150507 & $8 \%$ & $8 \%$ & $85 \%$ & $0 \%$ & $0 \%$ & $22 \%$ & $78 \%$ \\
\hline Lower Willow Creek & 100500150508 & $87 \%$ & $8 \%$ & $6 \%$ & $0 \%$ & $0 \%$ & $26 \%$ & $74 \%$ \\
\hline McEachern Creek & 100500150601 & $86 \%$ & $0 \%$ & $14 \%$ & $0 \%$ & $0 \%$ & $24 \%$ & $76 \%$ \\
\hline Bluff Creek & 100500150602 & $39 \%$ & $2 \%$ & $59 \%$ & $0 \%$ & $99 \%$ & $45 \%$ & $55 \%$ \\
\hline Rock Creek-Thoeny School & 100500150603 & $47 \%$ & $0 \%$ & $52 \%$ & $0 \%$ & $54 \%$ & $72 \%$ & $28 \%$ \\
\hline Rock Creek-Lake Grable & 100500150604 & $34 \%$ & $2 \%$ & $64 \%$ & $0 \%$ & $9 \%$ & $56 \%$ & $44 \%$ \\
\hline Rock Creek-Rock Creek Canyon & 100500150605 & $58 \%$ & $2 \%$ & $40 \%$ & $0 \%$ & $0 \%$ & $75 \%$ & $25 \%$ \\
\hline Cache Coulee & 100500150606 & $86 \%$ & $8 \%$ & $6 \%$ & $0 \%$ & $45 \%$ & $74 \%$ & $26 \%$ \\
\hline Lower Rock Creek & 100500150607 & $74 \%$ & $8 \%$ & $18 \%$ & $0 \%$ & $0 \%$ & $67 \%$ & $33 \%$ \\
\hline Bog Coulee & 100500160101 & $97 \%$ & $3 \%$ & $0 \%$ & $0 \%$ & $0 \%$ & $80 \%$ & $20 \%$ \\
\hline Headwaters of Snow Coulee & 100500160102 & $87 \%$ & $0 \%$ & $0 \%$ & $13 \%$ & $90 \%$ & $76 \%$ & $24 \%$ \\
\hline East Fork Snow Coulee & 100500160103 & $79 \%$ & $0 \%$ & $0 \%$ & $20 \%$ & $0 \%$ & $85 \%$ & $15 \%$ \\
\hline Lower Snow Coulee & 100500160104 & $5 \%$ & $0 \%$ & $0 \%$ & $95 \%$ & $4 \%$ & $96 \%$ & $4 \%$ \\
\hline $\begin{array}{l}\text { Upper Middle Fork } \\
\text { Porcupine Creek }\end{array}$ & 100500160201 & $100 \%$ & $0 \%$ & $0 \%$ & $0 \%$ & $0 \%$ & $60 \%$ & $40 \%$ \\
\hline $\begin{array}{l}\text { Middle Middle Fork } \\
\text { Porcupine Creek }\end{array}$ & 100500160202 & $94 \%$ & $3 \%$ & $1 \%$ & $2 \%$ & $0 \%$ & $67 \%$ & $33 \%$ \\
\hline $\begin{array}{l}\text { Lower Middle Fork } \\
\text { Porcupine Creek }\end{array}$ & 100500160203 & $7 \%$ & $1 \%$ & $0 \%$ & $92 \%$ & $27 \%$ & $86 \%$ & $14 \%$ \\
\hline Upper West Fork Porcupine Creek & 100500160301 & $18 \%$ & $11 \%$ & $72 \%$ & $0 \%$ & $13 \%$ & $60 \%$ & $40 \%$ \\
\hline Lower West Fork Porcupine Creek & 100500160302 & $24 \%$ & $55 \%$ & $3 \%$ & $18 \%$ & $0 \%$ & $91 \%$ & $9 \%$ \\
\hline Upper East Fork Porcupine Creek & 100500160401 & $0 \%$ & $0 \%$ & $0 \%$ & $100 \%$ & $33 \%$ & $80 \%$ & $20 \%$ \\
\hline Lower East Fork Porcupine Creek & 100500160402 & $0 \%$ & $0 \%$ & $0 \%$ & $100 \%$ & $49 \%$ & $86 \%$ & $14 \%$ \\
\hline Dry Fork Creek & 100500160501 & $8 \%$ & $91 \%$ & $1 \%$ & $0 \%$ & $7 \%$ & $88 \%$ & $12 \%$ \\
\hline Porcupine Creek-Olson Spring & 100500160502 & $24 \%$ & $54 \%$ & $3 \%$ & $18 \%$ & $0 \%$ & $74 \%$ & $26 \%$ \\
\hline Porcupine Creek-Enright Coulee & 100500160503 & $64 \%$ & $15 \%$ & $3 \%$ & $18 \%$ & $0 \%$ & $86 \%$ & $14 \%$ \\
\hline Porcupine Creek-Johnson Coulee & 100500160504 & $3 \%$ & $0 \%$ & $8 \%$ & $89 \%$ & $18 \%$ & $86 \%$ & $14 \%$ \\
\hline Sargent Creek & 100500160505 & $0 \%$ & $0 \%$ & $0 \%$ & $100 \%$ & $0 \%$ & $88 \%$ & $12 \%$ \\
\hline Lower Porcupine Creek & 100500160506 & $2 \%$ & $0 \%$ & $0 \%$ & $98 \%$ & $0 \%$ & $92 \%$ & $8 \%$ \\
\hline Galpin Coulee & 100600010101 & $0 \%$ & $0 \%$ & $0 \%$ & $0 \%$ & $0 \%$ & $0 \%$ & $0 \%$ \\
\hline Missouri River-Fort Peck Dam & 100600010102 & $0 \%$ & $0 \%$ & $0 \%$ & $0 \%$ & $0 \%$ & $0 \%$ & $0 \%$ \\
\hline $\begin{array}{l}\text { Upper East Fork Little } \\
\text { Porcupine Creek }\end{array}$ & 100600010201 & $0 \%$ & $0 \%$ & $0 \%$ & $0 \%$ & $0 \%$ & $0 \%$ & $0 \%$ \\
\hline West Fork Little Porcupine & 100600010203 & $0 \%$ & $0 \%$ & $0 \%$ & $0 \%$ & $0 \%$ & $0 \%$ & $0 \%$ \\
\hline Tomato Can Creek & 100600010301 & $0 \%$ & $0 \%$ & $0 \%$ & $0 \%$ & $11 \%$ & $0 \%$ & $0 \%$ \\
\hline Upper Charley Creek & 100600010302 & $0 \%$ & $0 \%$ & $0 \%$ & $100 \%$ & $2 \%$ & $100 \%$ & $0 \%$ \\
\hline Lower Charley Creek & 100600010303 & $0 \%$ & $0 \%$ & $0 \%$ & $0 \%$ & $0 \%$ & $0 \%$ & $0 \%$ \\
\hline Lower Little Porcupine Creek & 100600010304 & $0 \%$ & $0 \%$ & $0 \%$ & $0 \%$ & $0 \%$ & $0 \%$ & $0 \%$ \\
\hline Missouri River-Lost Creek & 100600010802 & $0 \%$ & $0 \%$ & $0 \%$ & $0 \%$ & $0 \%$ & $0 \%$ & $0 \%$ \\
\hline Lower Roanwood Creek & 100600040101 & $0 \%$ & $0 \%$ & $0 \%$ & $0 \%$ & $0 \%$ & $0 \%$ & $0 \%$ \\
\hline
\end{tabular}


Wetland Landscape Profiling of Palustrine Wetlands: Sixth-Code Hydrological Unit 6th Code HUC Name

\begin{tabular}{cccccccc} 
HUC Number & Private & State & Federal & Tribal & Protected & Natural Altered \\
\hline 100600040102 & $0 \%$ & $0 \%$ & $0 \%$ & $0 \%$ & $42 \%$ & $0 \%$ & $0 \%$ \\
100600040201 & $0 \%$ & $0 \%$ & $0 \%$ & $0 \%$ & $0 \%$ & $0 \%$ & $0 \%$ \\
& & & & & & & \\
100600040204 & $0 \%$ & $0 \%$ & $0 \%$ & $0 \%$ & $0 \%$ & $0 \%$ & $0 \%$ \\
100600040205 & $0 \%$ & $0 \%$ & $0 \%$ & $0 \%$ & $14 \%$ & $0 \%$ & $0 \%$ \\
& & & & & & & \\
100600040301 & $0 \%$ & $0 \%$ & $0 \%$ & $0 \%$ & $0 \%$ & $0 \%$ & $0 \%$ \\
170102070101 & $0 \%$ & $0 \%$ & $0 \%$ & $0 \%$ & $0 \%$ & $0 \%$ & $0 \%$ \\
170102070102 & $0 \%$ & $0 \%$ & $0 \%$ & $0 \%$ & $0 \%$ & $0 \%$ & $0 \%$ \\
& & & & & & & \\
170102070103 & $0 \%$ & $0 \%$ & $0 \%$ & $0 \%$ & $19 \%$ & $0 \%$ & $0 \%$ \\
170102070104 & $0 \%$ & $0 \%$ & $0 \%$ & $0 \%$ & $0 \%$ & $0 \%$ & $0 \%$ \\
170102070201 & $0 \%$ & $0 \%$ & $0 \%$ & $0 \%$ & $0 \%$ & $0 \%$ & $0 \%$ \\
170102070203 & $0 \%$ & $0 \%$ & $0 \%$ & $0 \%$ & $0 \%$ & $0 \%$ & $0 \%$ \\
170102070301 & $0 \%$ & $0 \%$ & $0 \%$ & $0 \%$ & $0 \%$ & $0 \%$ & $0 \%$ \\
& & & & & & & \\
170102070303 & $0 \%$ & $0 \%$ & $0 \%$ & $0 \%$ & $0 \%$ & $0 \%$ & $0 \%$ \\
170102070304 & $0 \%$ & $0 \%$ & $0 \%$ & $0 \%$ & $29 \%$ & $0 \%$ & $0 \%$ \\
170102070401 & $0 \%$ & $0 \%$ & $0 \%$ & $0 \%$ & $92 \%$ & $0 \%$ & $0 \%$ \\
170102070403 & $0 \%$ & $0 \%$ & $0 \%$ & $0 \%$ & $0 \%$ & $0 \%$ & $0 \%$ \\
170102070404 & $0 \%$ & $0 \%$ & $0 \%$ & $0 \%$ & $0 \%$ & $0 \%$ & $0 \%$ \\
170102070501 & $0 \%$ & $0 \%$ & $0 \%$ & $0 \%$ & $0 \%$ & $0 \%$ & $0 \%$ \\
170102070502 & $0 \%$ & $0 \%$ & $100 \%$ & $0 \%$ & $0 \%$ & $10 \%$ & $0 \%$
\end{tabular}

Upper Roanwood Creek

West Fork Poplar RiverHappy Valley

Spring Coulee

West Fork Poplar RiverDolson Coulee

Upper Hell Creek

Strawberry Creek

Middle Fork Flathead RiverTrail Creek

Bowl Creek

Cox Creek

Morrison Creek

Granite Creek

Middle Fork Flathead RiverBear Creek

Ole Creek

Park Creek

Upper Nyack Creek

Harrison Creek

Lincoln Creek

McDonald Creek Headwaters

McDonald Creek

170102070502 

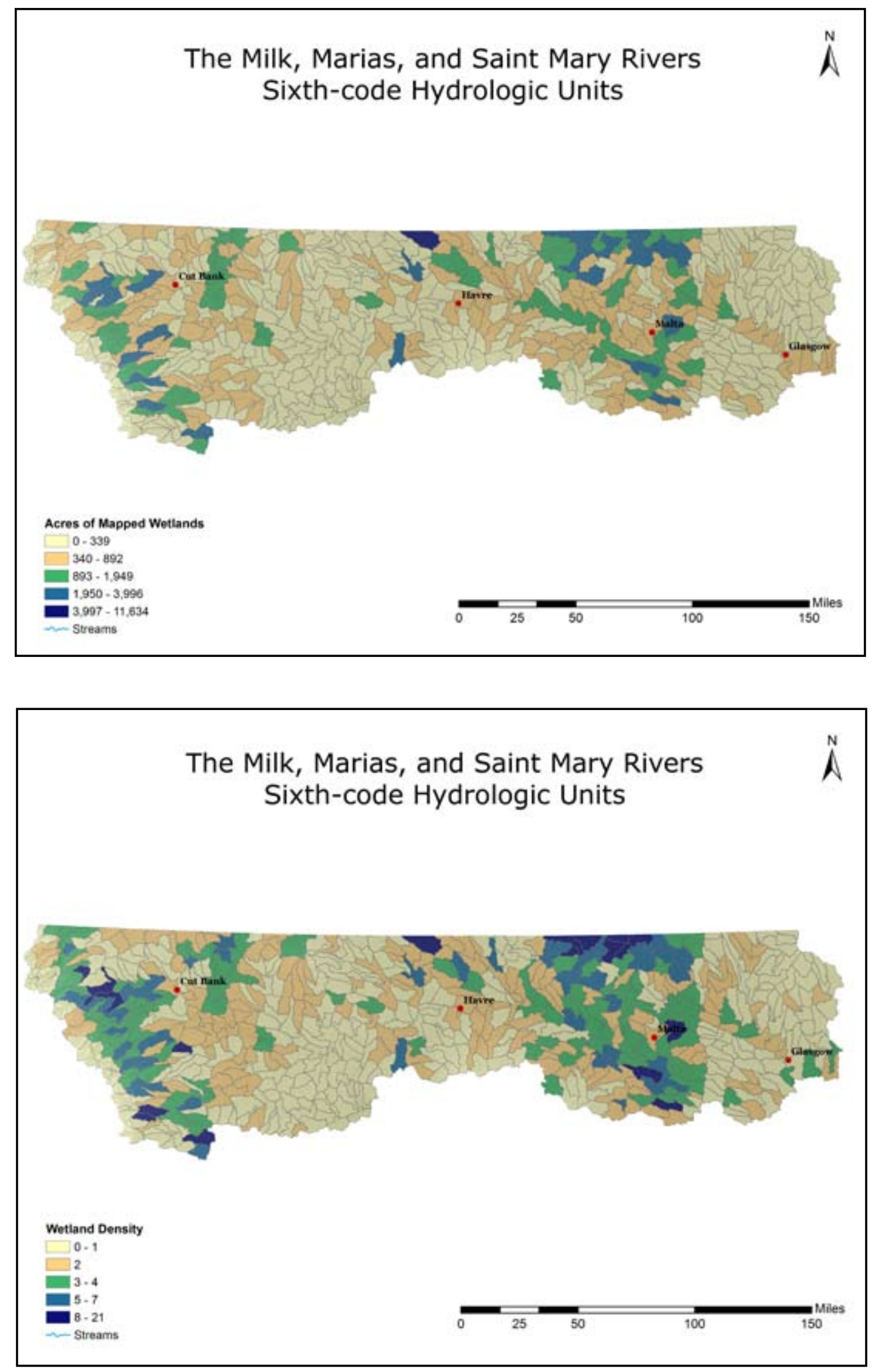

Appendix I- 21 
The Milk, Marias, and Saint Mary Rivers

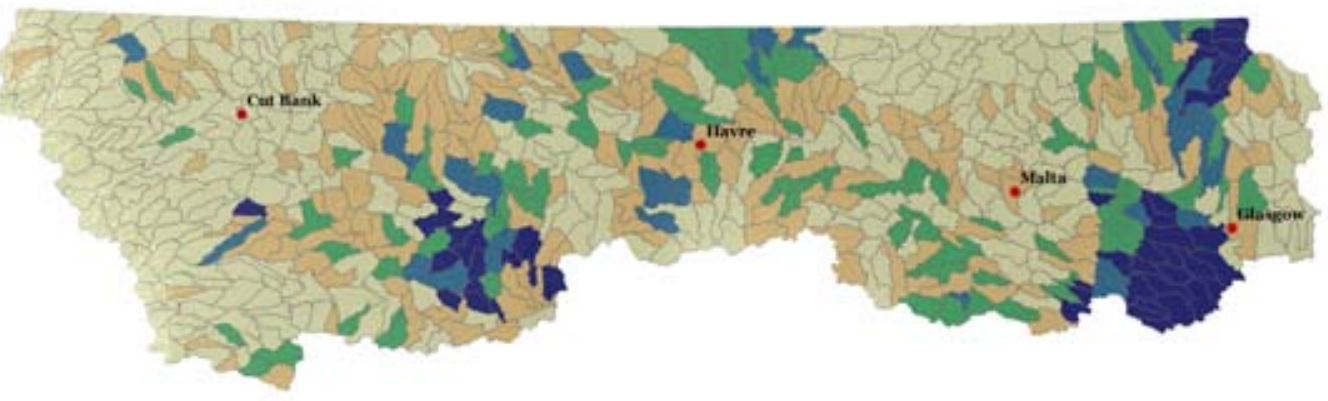

Percent of Altered Wetlands

$0 \%-20 \%$

$21 \%-40 \%$

$41 \%-60 \%$

$61 \%-80 \%$

$81 \%-100 \%$

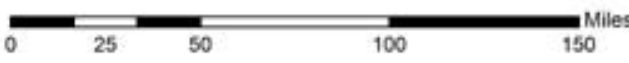

- Streams

The Milk, Marias, and Saint Mary Rivers Sixth-code Hydrologic Units

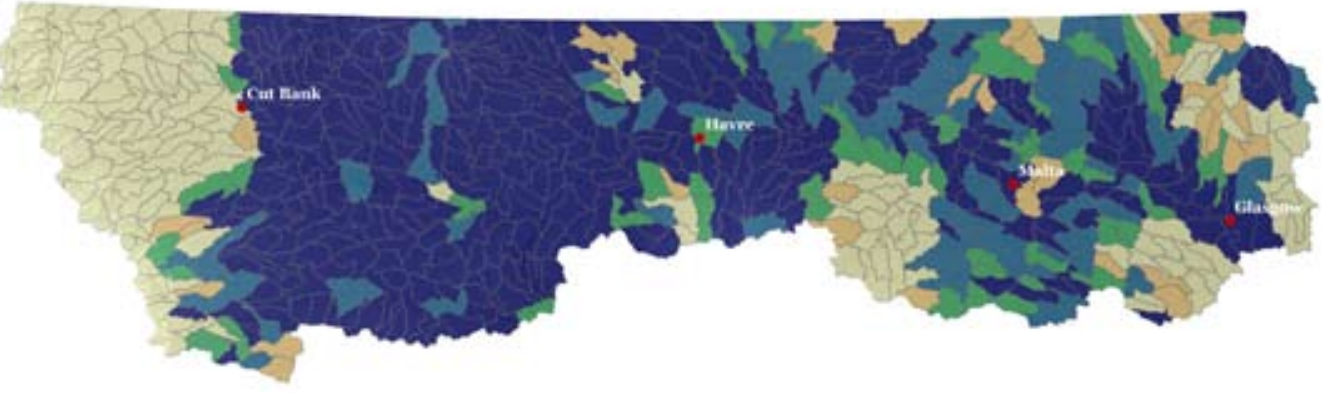

Percent of Mapped Wotlands on Private Land

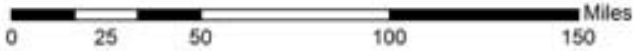

- Streams 


\section{Appendix J. Level 1 Attribute Frequency Histograms for Three Landscape Scales}




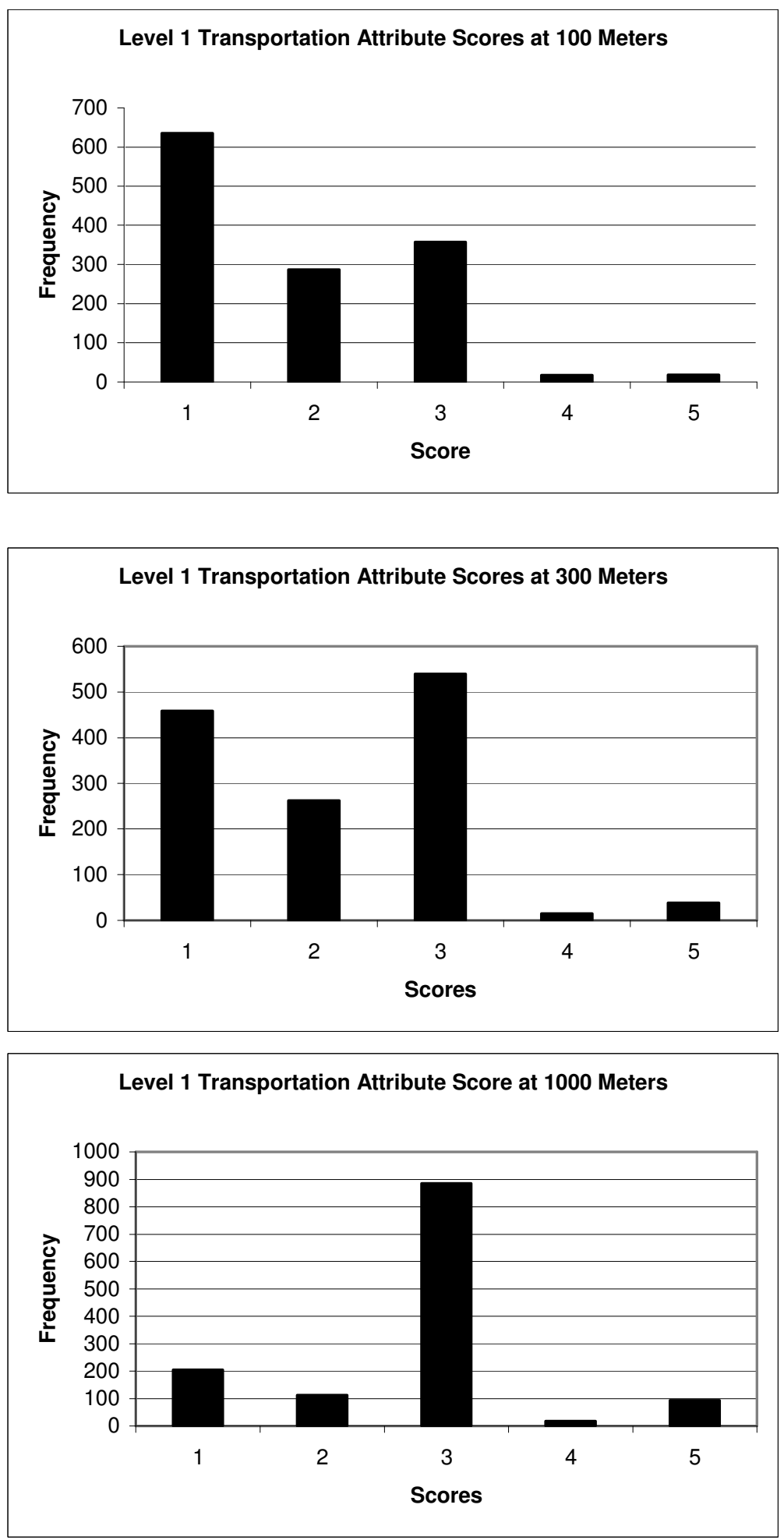

Appendix $J$ - 1 

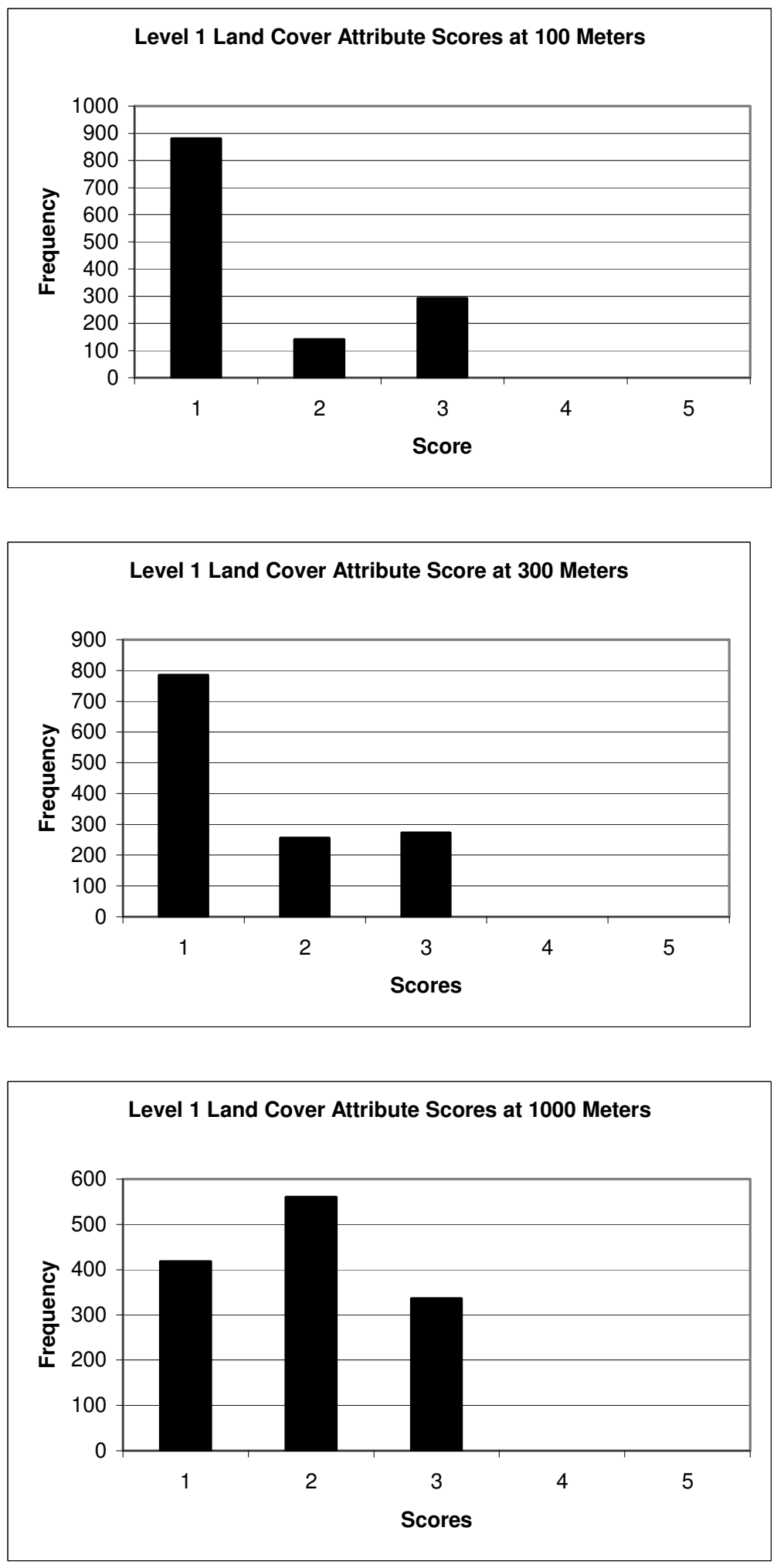

Appendix $J$ - 2 

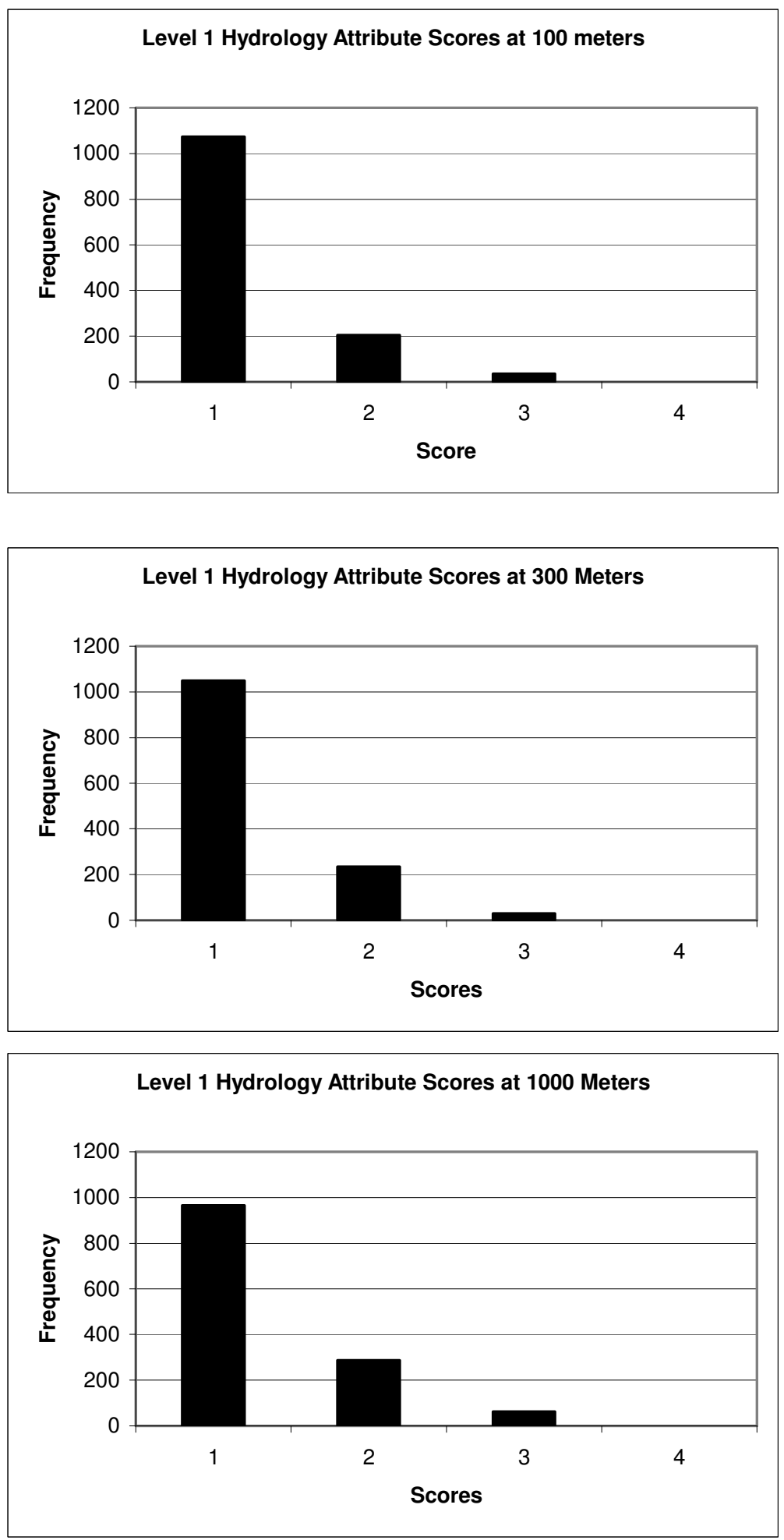

Appendix $J$ - 3 

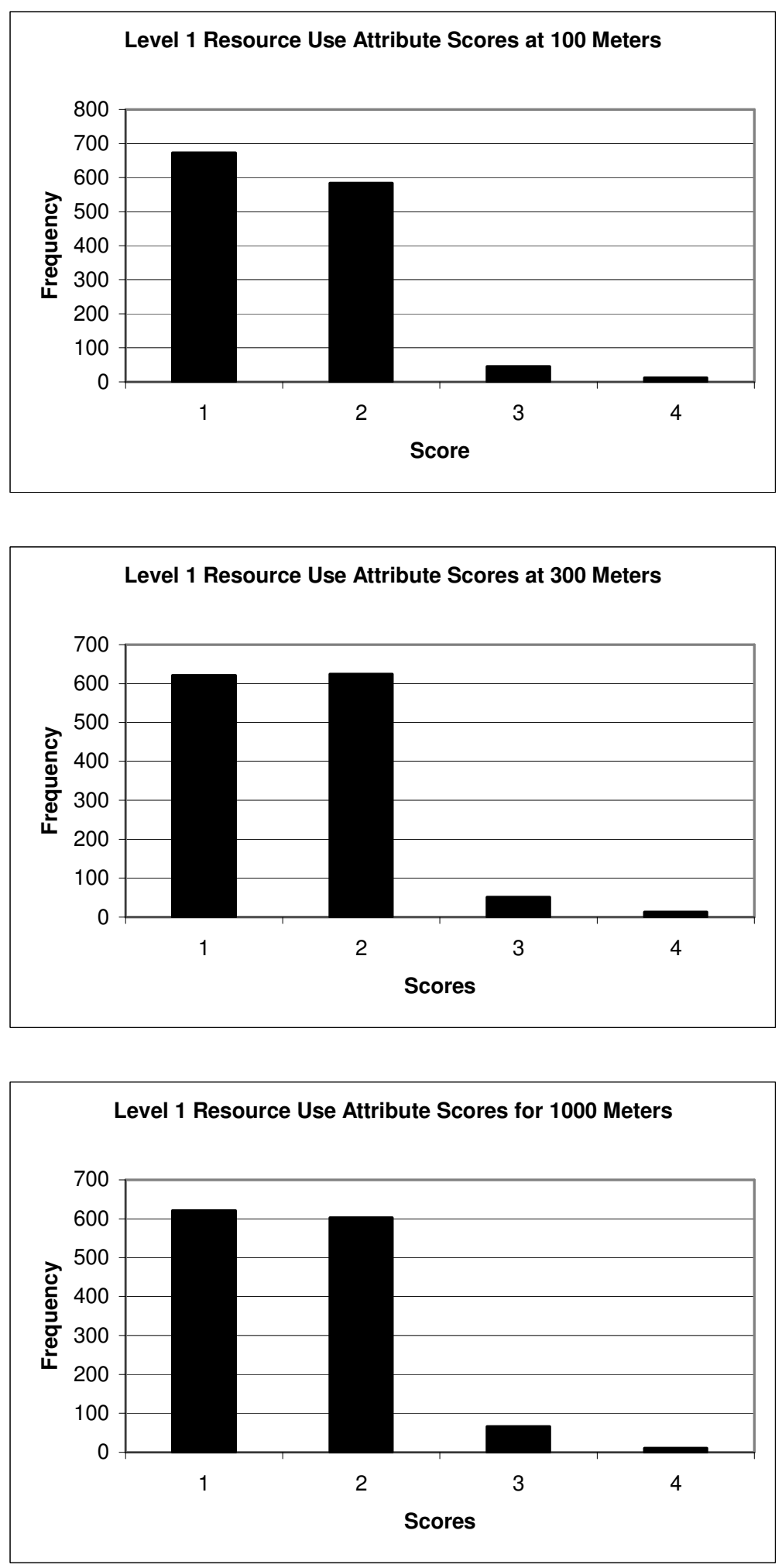

Appendix $J$ - 4 

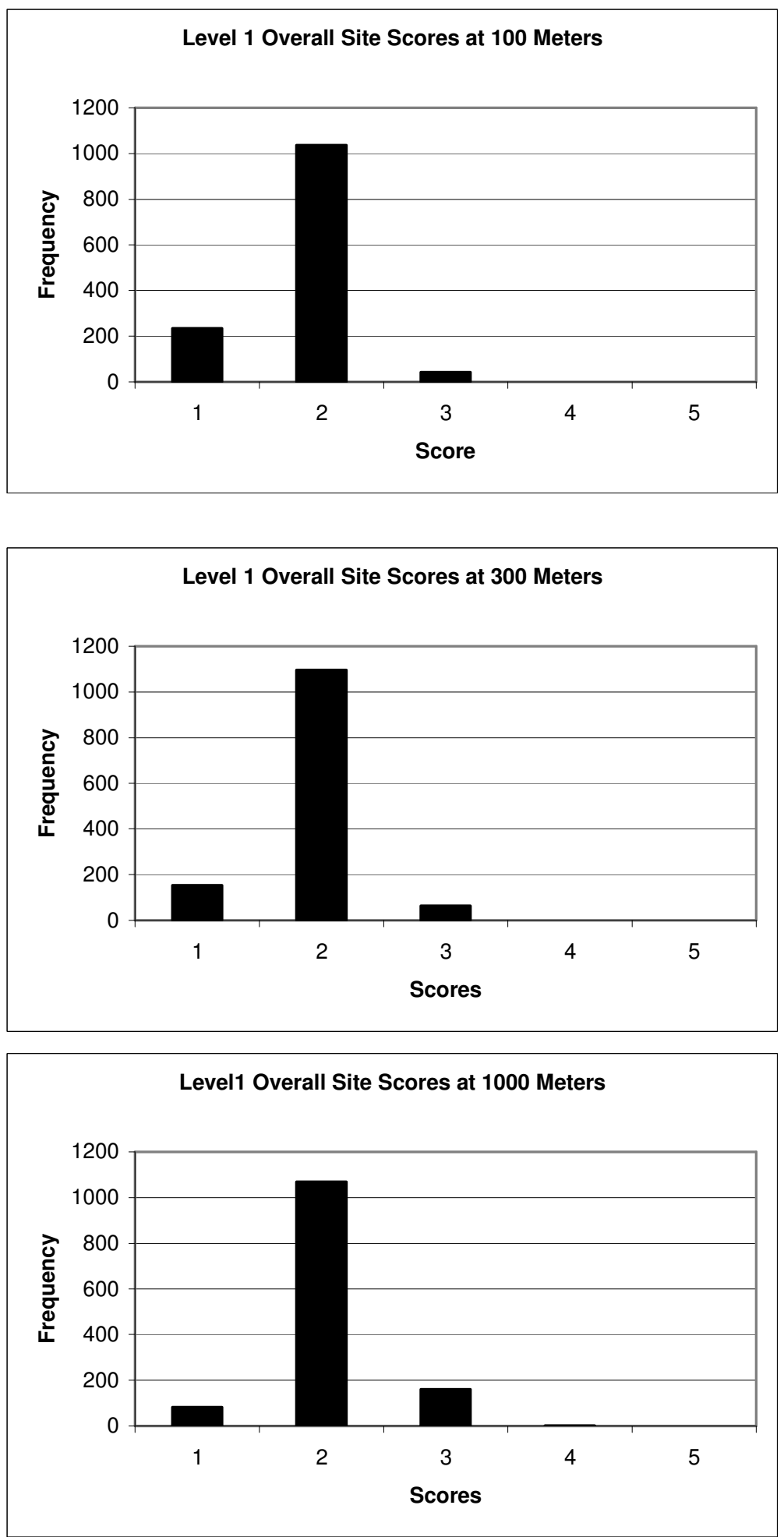

Appendix $J$ - 5 

Appendix K. Level 2 Attribute Frequency Histograms 


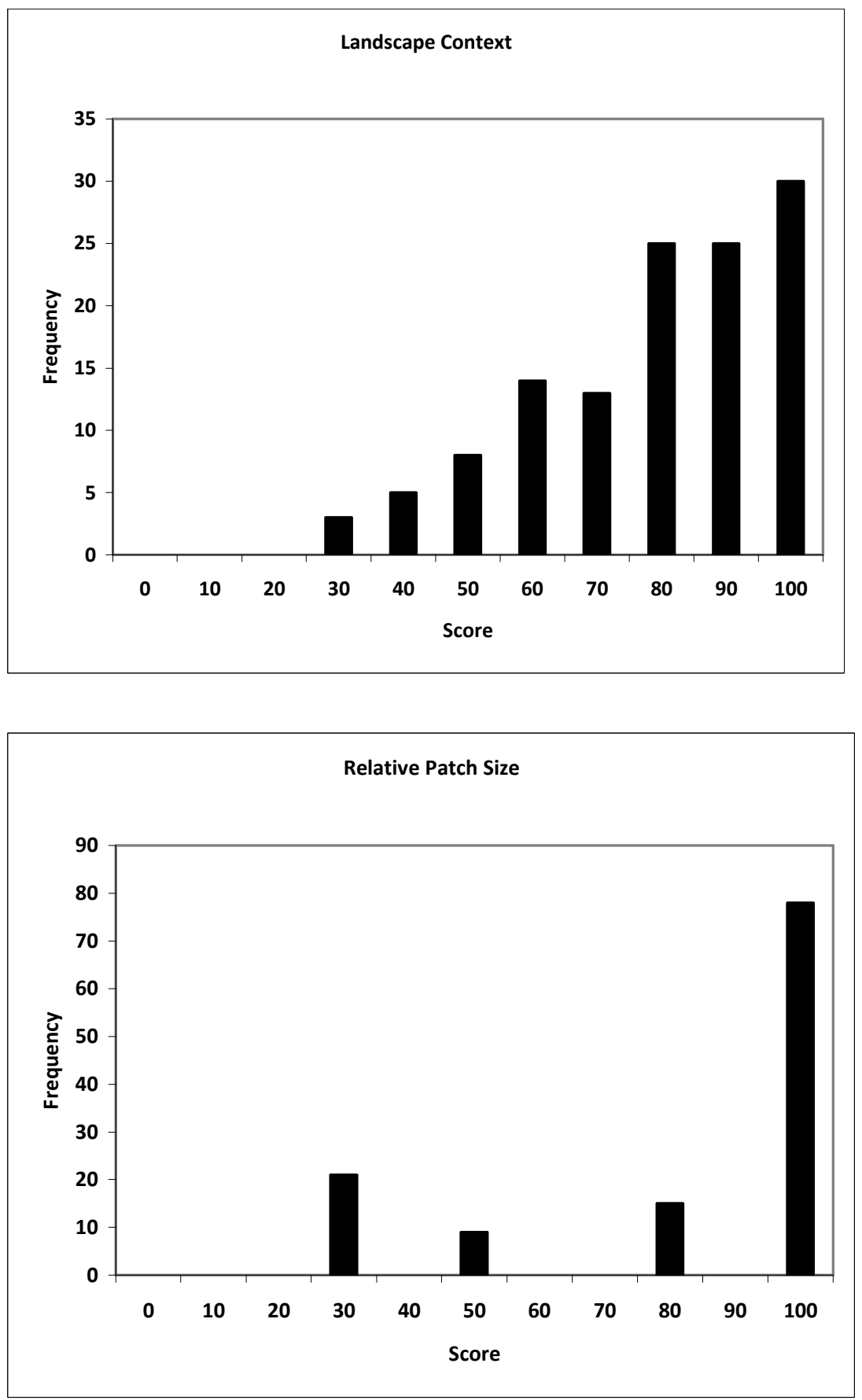

Appendix K - 1 

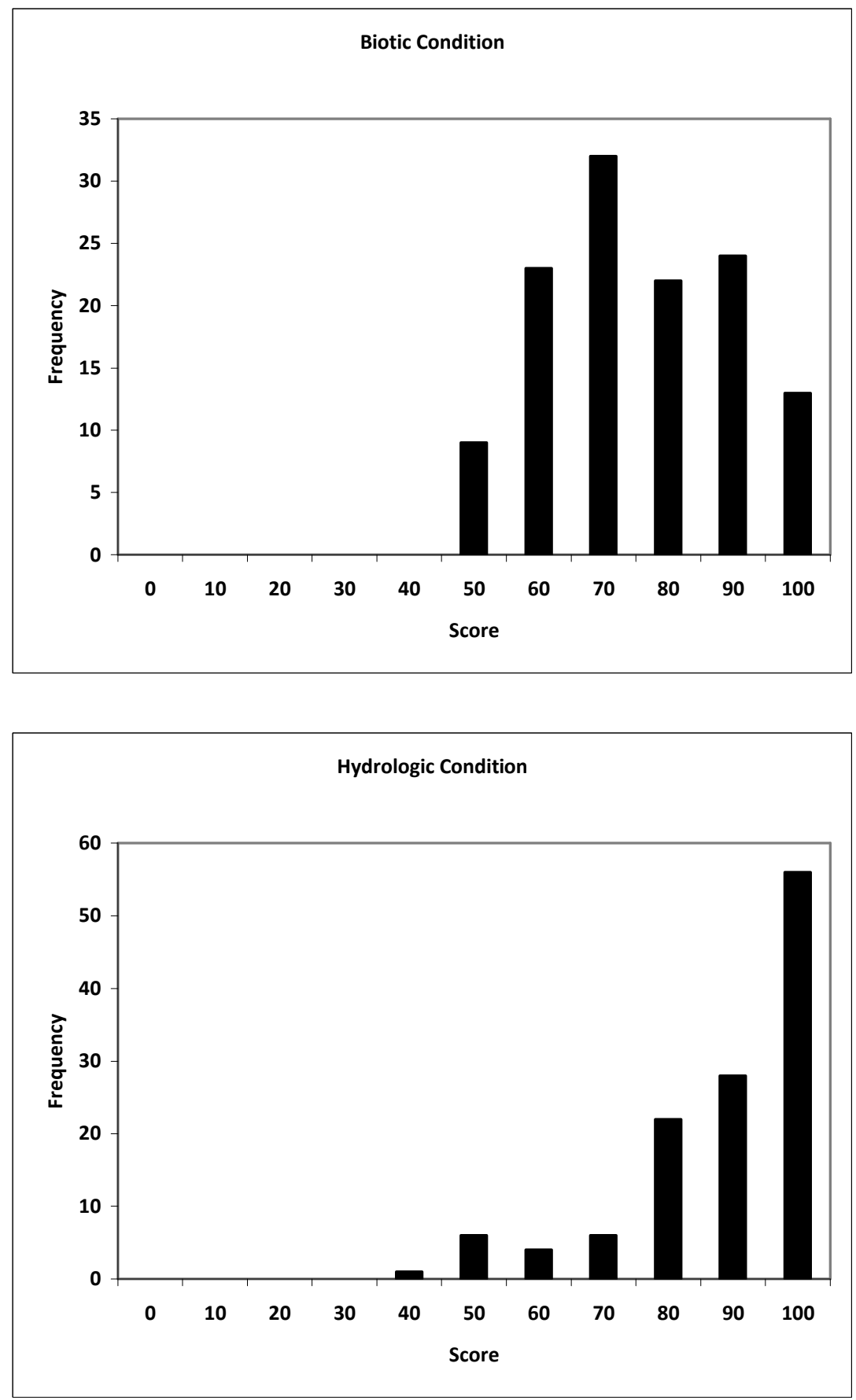

Appendix K - 2 


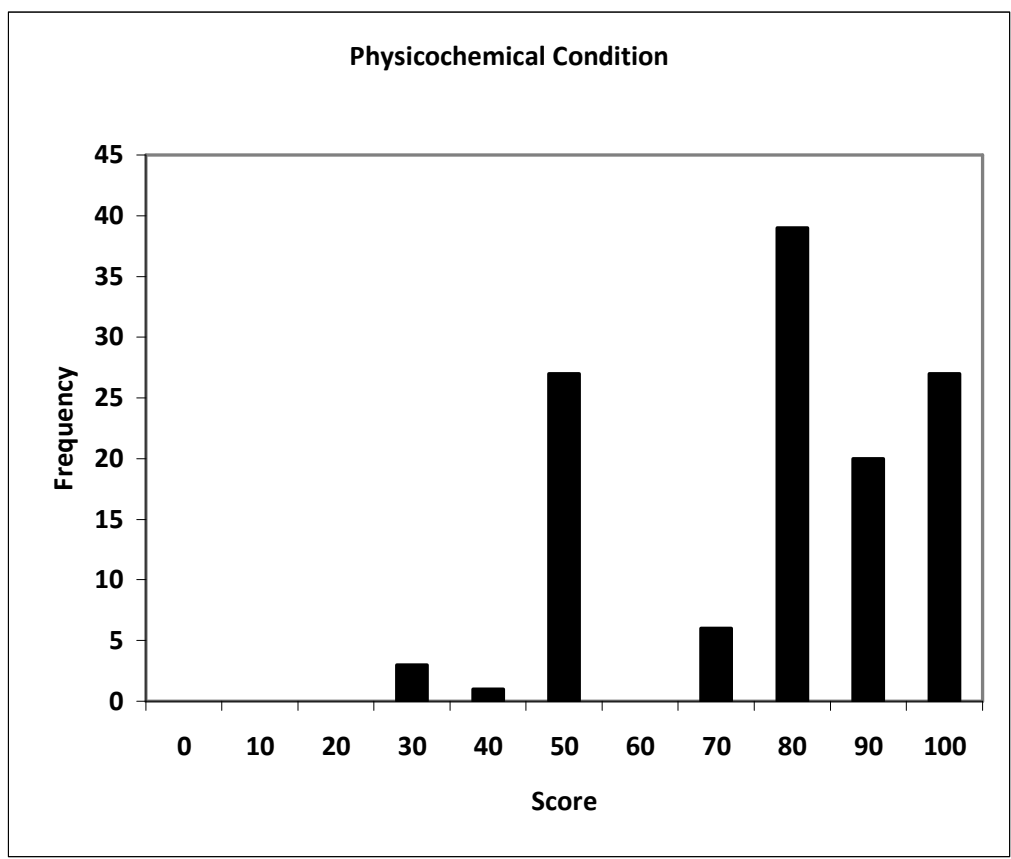

Appendix K - 3 

Appendix L. Level 2 Scores for Each Ecological System 

Great Plains Prairie Pothole N=19

\begin{tabular}{lcccc}
\hline & Mean & S.D. & Min & Max \\
\hline \hline & & & & \\
Landscape Condition & 83.6 & 14.5 & 55.6 & 100.0 \\
Patch Size & 82.9 & 26.4 & 25.0 & 100.0 \\
Biotic & 79.5 & 11.3 & 52.8 & 94.4 \\
Hydrologic & 89.9 & 12.6 & 66.7 & 100.0 \\
Physiochemical & 82.2 & 19.7 & 25.0 & 100.0 \\
Total AA & 83.6 & 11.1 & 57.5 & 98.3
\end{tabular}

North American Arid West Emergent Marsh N=5

\begin{tabular}{lcccc}
\hline & Mean & S.D. & Min & Max \\
\hline \hline Landscape Condition & 66.2 & 19.1 & 42.7 & 93.3 \\
Patch Size & 100.0 & 0.0 & 100.0 & 100.0 \\
Biotic & 76.7 & 14.8 & 55.6 & 88.9 \\
Hydrologic & 80.0 & 19.2 & 50.0 & 100.0 \\
Physiochemical & 87.5 & 15.3 & 62.5 & 100.0 \\
Total AA & 82.1 & 6.5 & 74.9 & 89.8
\end{tabular}

Northwestern Great Plains Riparian N=15

\begin{tabular}{lcccc}
\hline & Mean & S.D. & Min & Max \\
\hline \hline Landscape Condition & 77.0 & 15.6 & 50.0 & 100.0 \\
Patch Size & 68.3 & 34.7 & 25.0 & 100.0 \\
Biotic & 65.9 & 13.0 & 41.7 & 88.9 \\
Hydrologic & 81.7 & 19.7 & 50.0 & 100.0 \\
Physiochemical & 68.3 & 22.1 & 25.0 & 100.0 \\
Total AA & 72.2 & 12.1 & 53.2 & 92.2
\end{tabular}

Rocky Mountain Alpine-Montane Wet Meadow N=6

\begin{tabular}{lcccc}
\hline & Mean & S.D. & Min & Max \\
\hline \hline Landscape Condition & 67.7 & 23.2 & 35.8 & 100.0 \\
Patch Size & 95.8 & 10.2 & 75.0 & 100.0 \\
Biotic & 82.9 & 11.6 & 66.7 & 97.2 \\
Hydrologic & 87.5 & 17.3 & 58.3 & 100.0 \\
Physiochemical & 93.8 & 10.5 & 75.0 & 100.0 \\
Total AA & 85.5 & 10.2 & 71.6 & 98.3
\end{tabular}

Western Great Plains Closed Depression Wetland N=13

\begin{tabular}{lcccc}
\hline & Mean & S.D. & Min & Max \\
\hline \hline Landscape Condition & 64.8 & 18.7 & 30.2 & 90.3 \\
Patch Size & 76.9 & 33.0 & 25.0 & 100.0 \\
Biotic & 67.3 & 11.6 & 55.6 & 91.7 \\
Hydrologic & 84.6 & 19.5 & 33.3 & 100.0 \\
Physiochemical & 73.1 & 21.6 & 25.0 & 100.0 \\
Total AA & 73.4 & 13.7 & 42.7 & 87.7
\end{tabular}


Western Great Plains Open Freshwater Depression Wetland N=49

\begin{tabular}{lcccc}
\hline & Mean & S.D. & Min & Max \\
\hline \hline Landscape Condition & 71.3 & 26.1 & 25.0 & 100.0 \\
Patch Size & 77.0 & 24.1 & 25.0 & 100.0 \\
Biotic & 65.5 & 15.8 & 41.7 & 91.7 \\
Hydrologic & 83.2 & 16.7 & 50.0 & 100.0 \\
Physiochemical & 69.9 & 14.8 & 37.5 & 100.0 \\
Total AA & 73.4 & 11.7 & 47.7 & 98.3
\end{tabular}

Western Great Plains Saline Depression Wetland N=8

\begin{tabular}{lcccc}
\hline & Mean & S.D. & Min & Max \\
\hline \hline Landscape Condition & 86.2 & 11.3 & 67.0 & 100.0 \\
Patch Size & 96.9 & 8.8 & 75.0 & 100.0 \\
Biotic & 76.7 & 13.3 & 58.3 & 97.2 \\
Hydrologic & 93.8 & 7.4 & 83.3 & 100.0 \\
Physiochemical & 82.8 & 16.3 & 50.0 & 100.0 \\
Total AA & 87.3 & 7.9 & 73.7 & 96.7
\end{tabular}

Rocky Mountain Subalpine-Montane Riparian Shrubland N=2

\begin{tabular}{lcccc}
\hline & Mean & S.D. & Min & Max \\
\hline \hline Landscape Condition & 93.8 & 8.8 & 87.5 & 100.0 \\
Patch Size & 100.0 & 0.0 & 100.0 & 100.0 \\
Biotic & 88.9 & 7.9 & 83.3 & 94.4 \\
Hydrologic & 100.0 & 0.0 & 100.0 & 100.0 \\
Physiochemical & 87.5 & 17.7 & 75.0 & 100.0 \\
Total AA & 94.0 & 3.3 & 91.7 & 96.4
\end{tabular}




\section{Appendix M. Level 2 Attribute and Overall Condition Score Frequency Histograms by Wetland Ecological Systems WITH $N=\geq 8$ SITES}



Landscape Context Scores-Great Plains Prairie Pothole

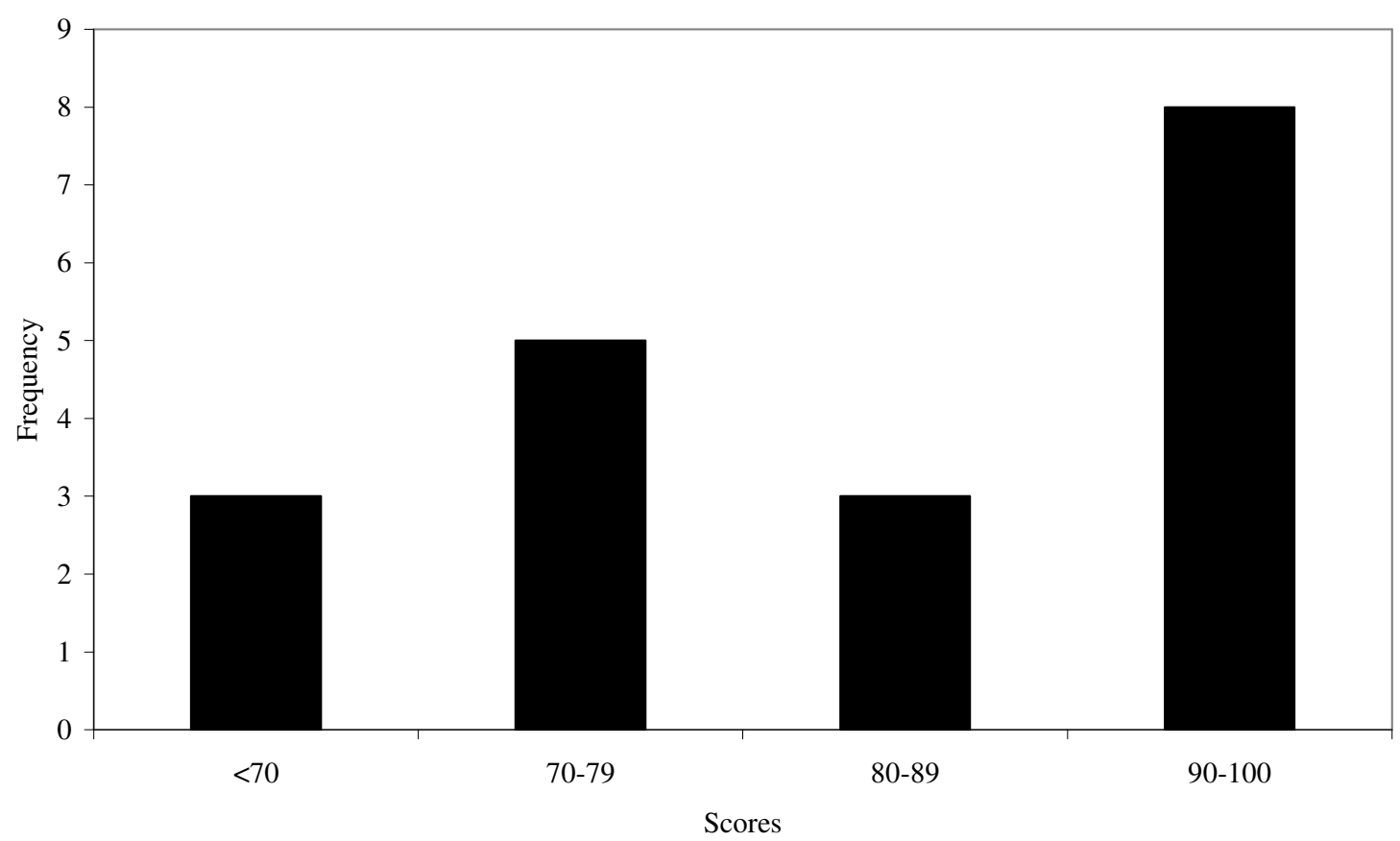

Landscape Context Scores-Western Great Plains Closed Depression Wetland

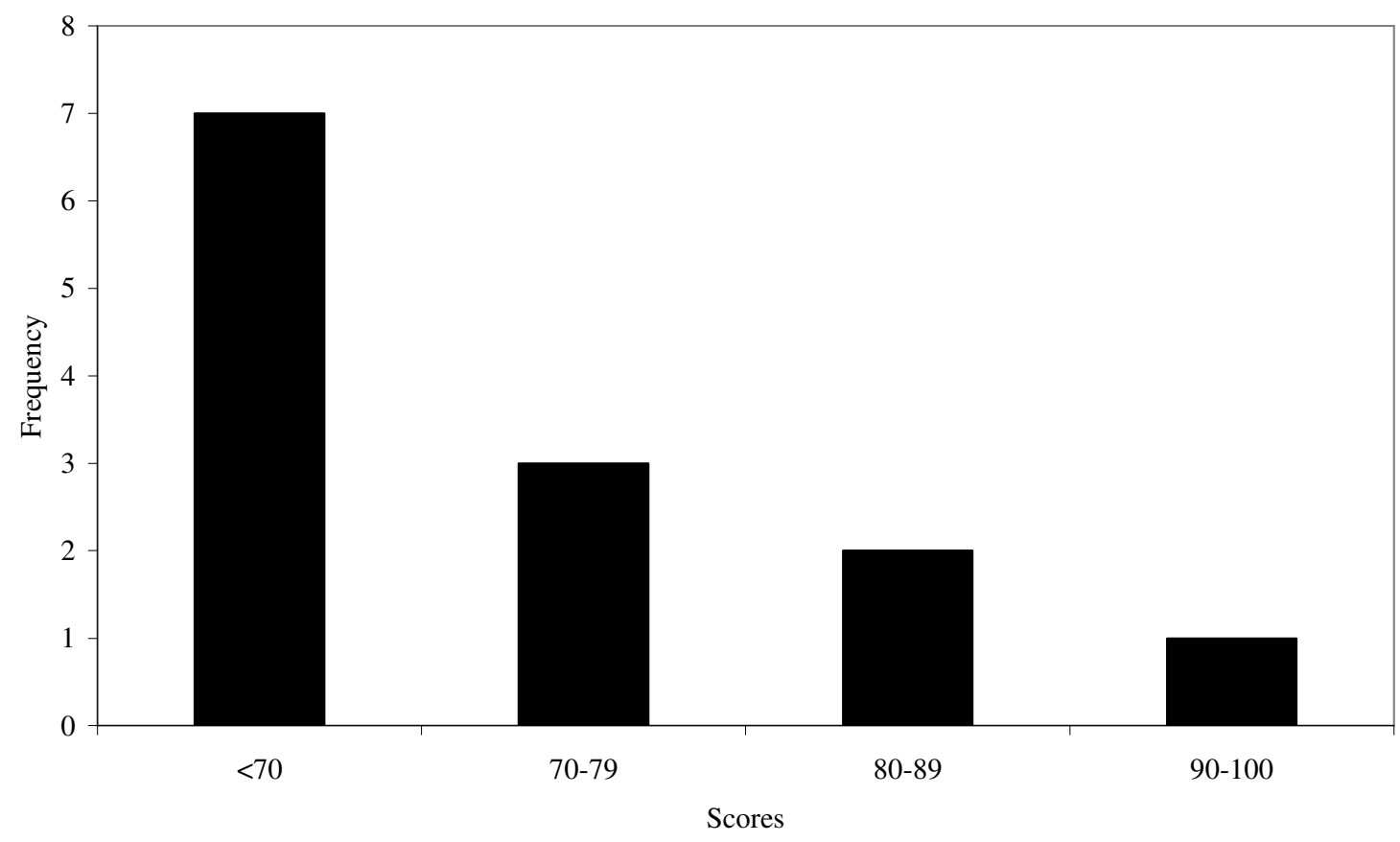


Landscape Context Scores-Western Great Plains Open Freshwater Depression Wetland

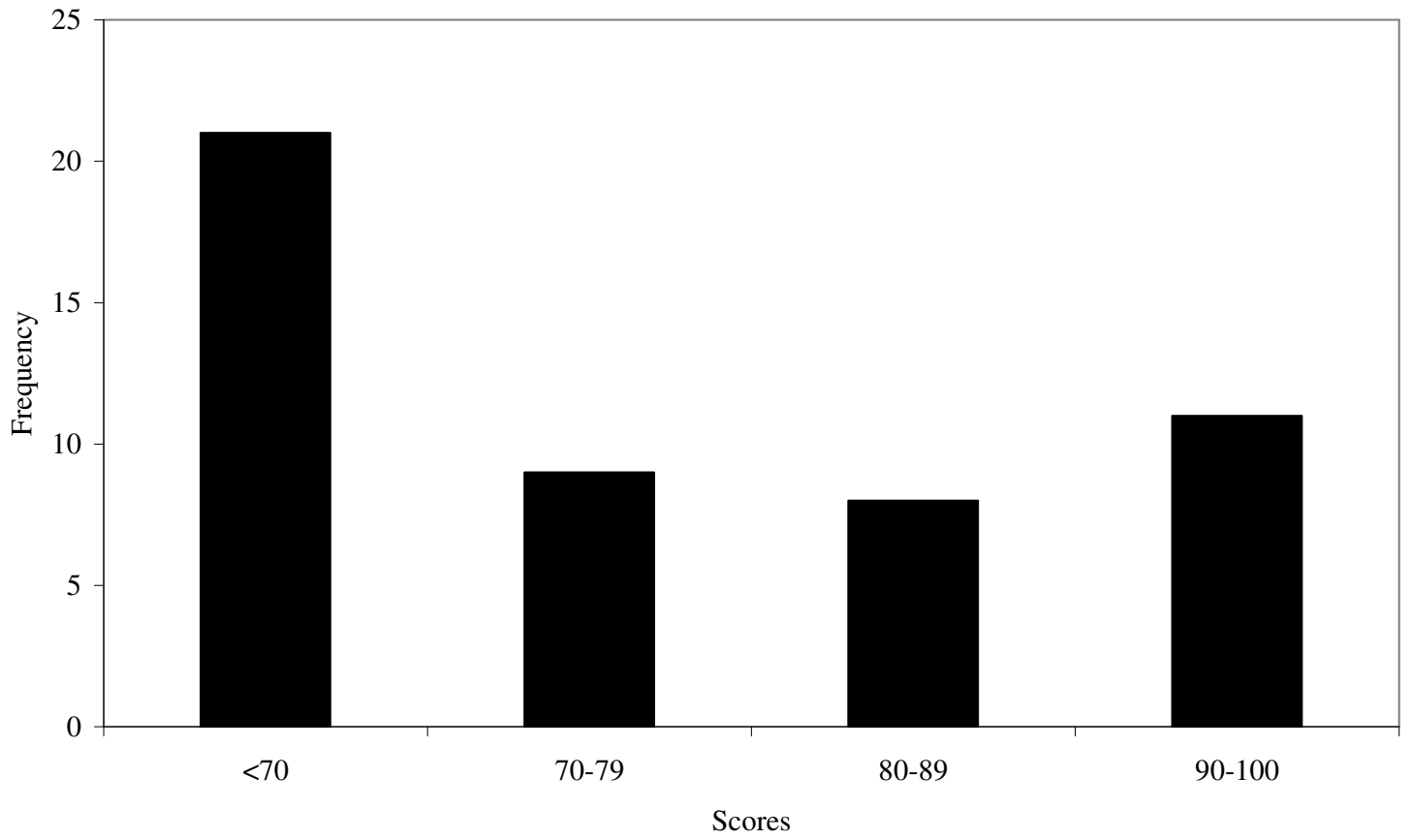

Landscape Context Scores-Western Great Plains Saline Depression Wetland

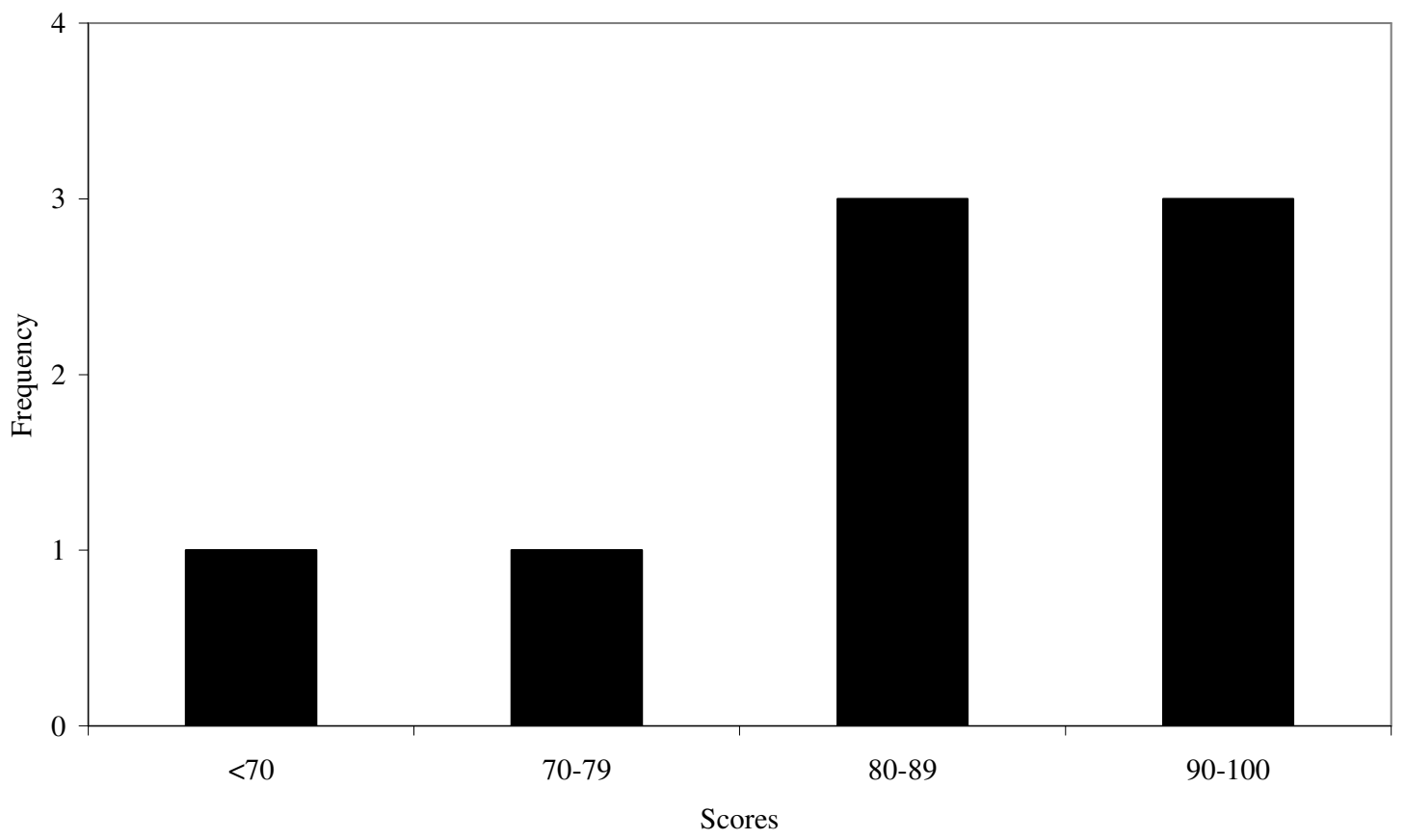


Landscape Context Scores-Northwestern Great Plains Riparian

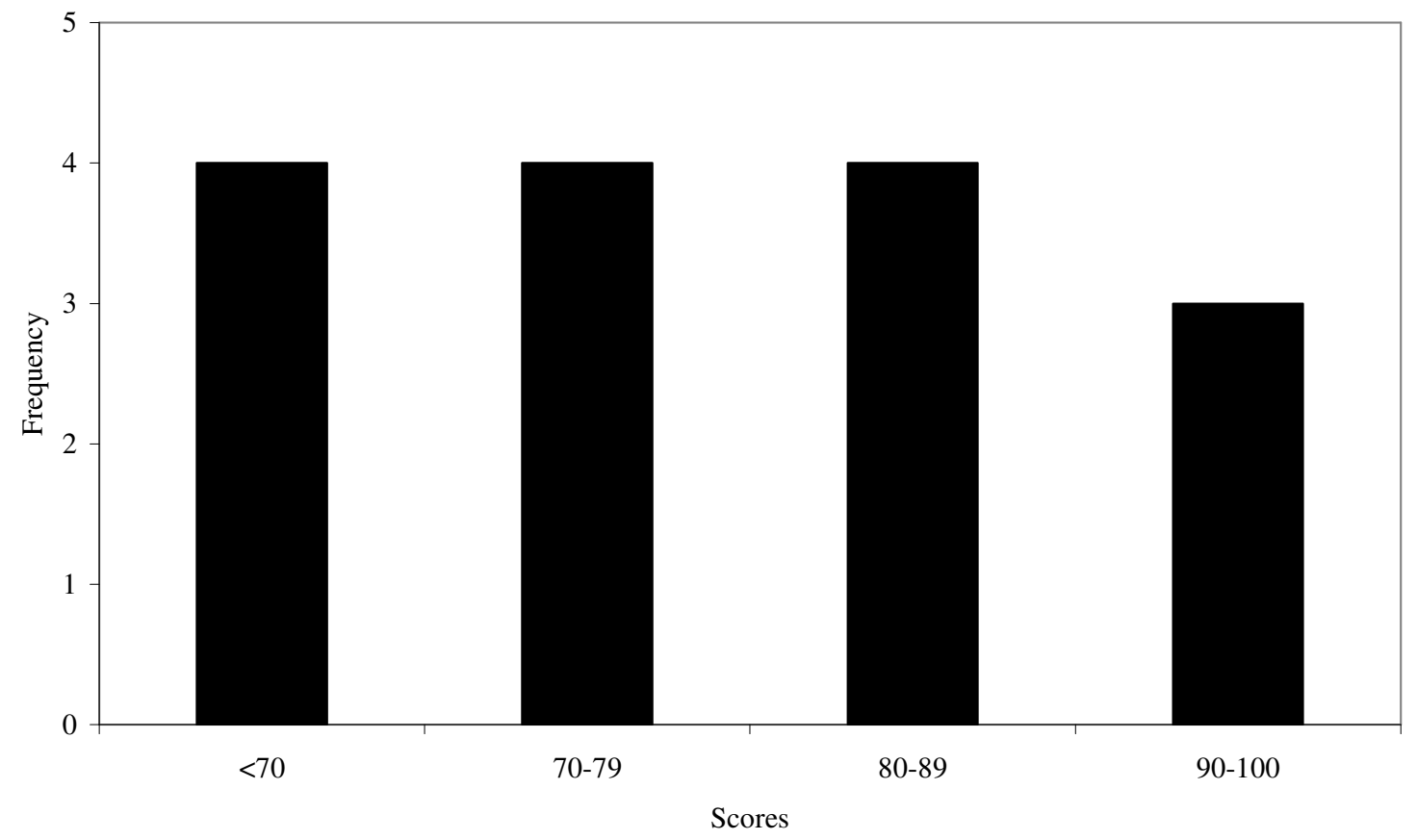

Relative Wetland Size Scores-Great Plains Prairie Pothole

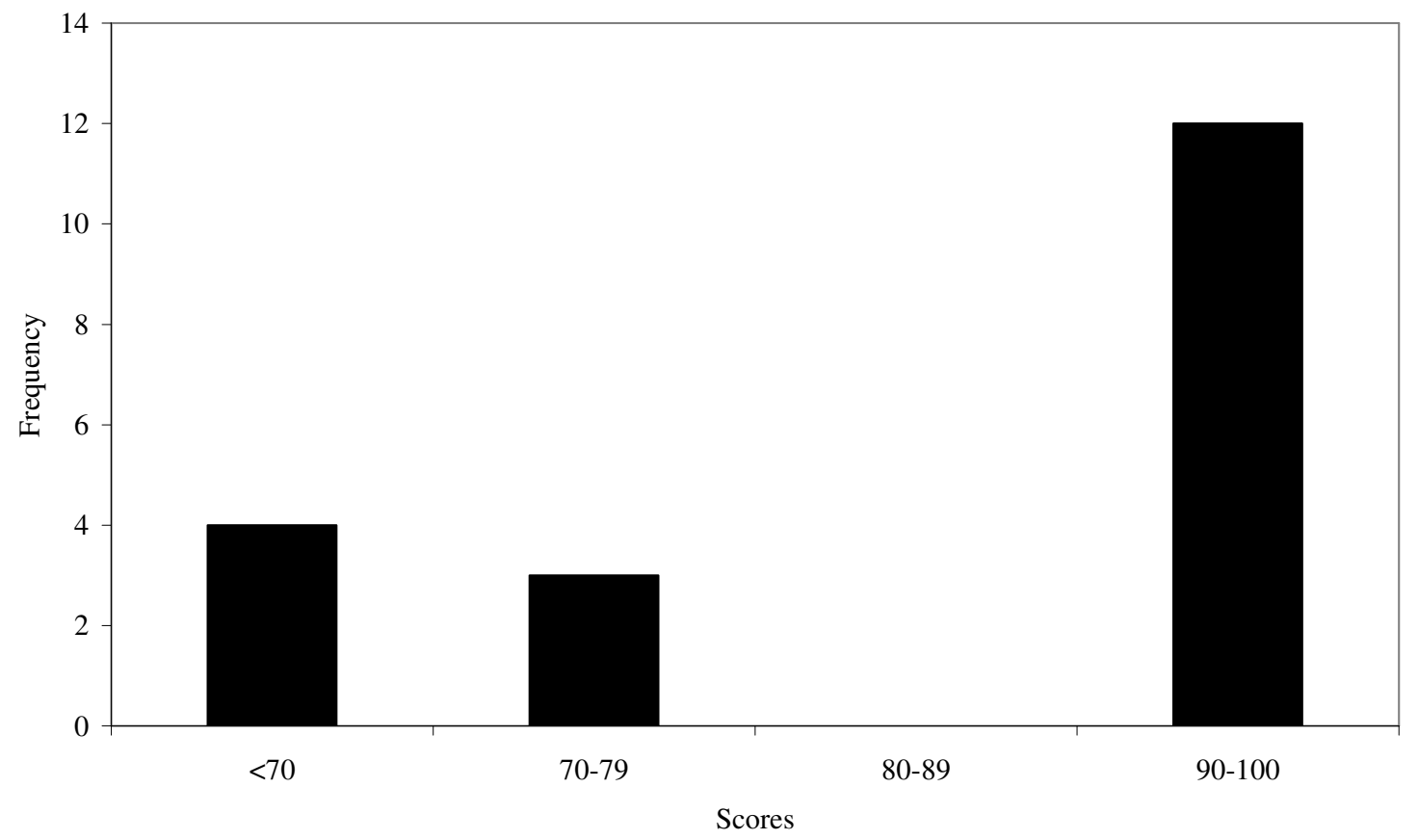


Relative Wetland Size Scores-Western Great Plains Closed Depression Wetland

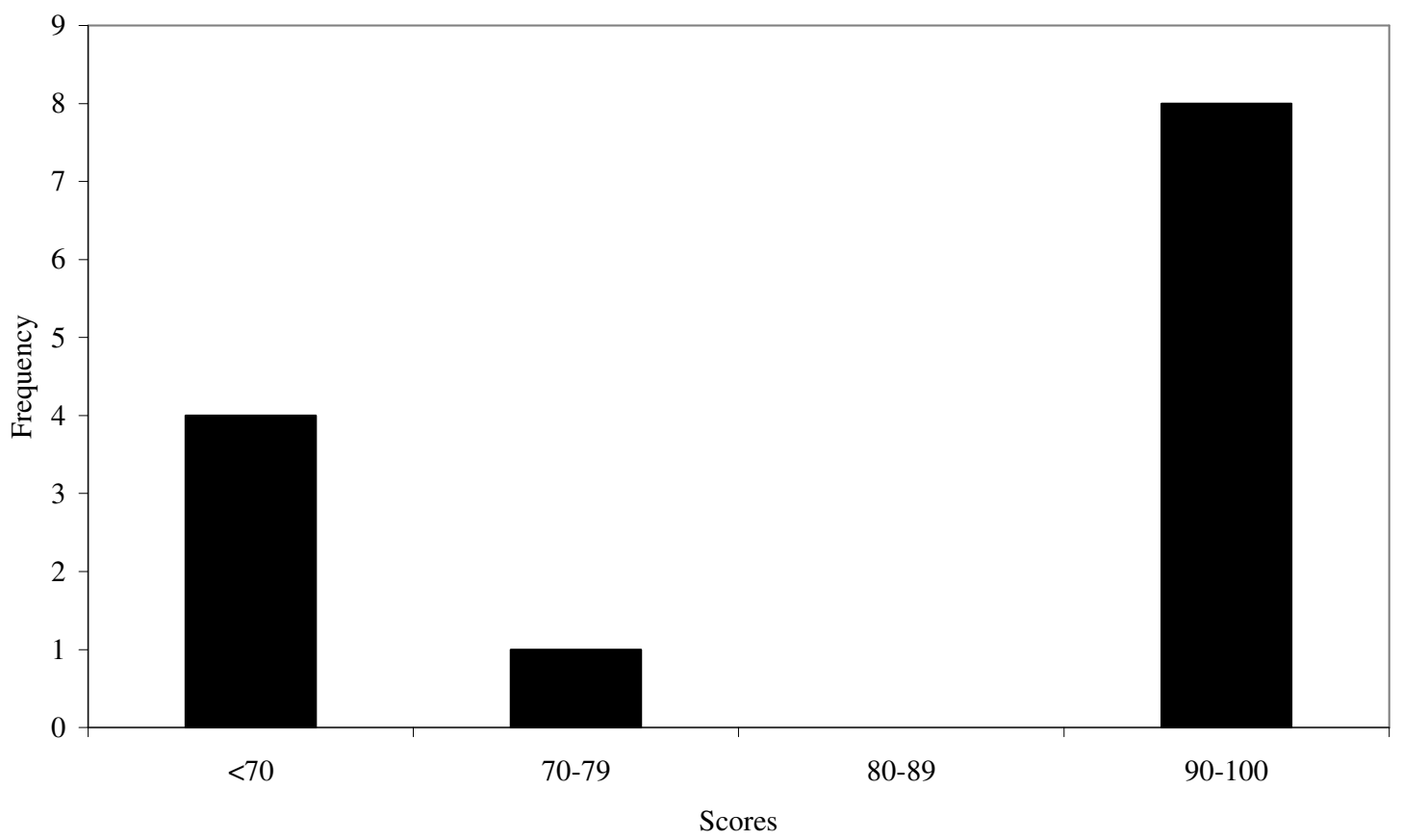

Relative Wetland Size Scores-Western Great Plains Open Freshwater Depression Wetland

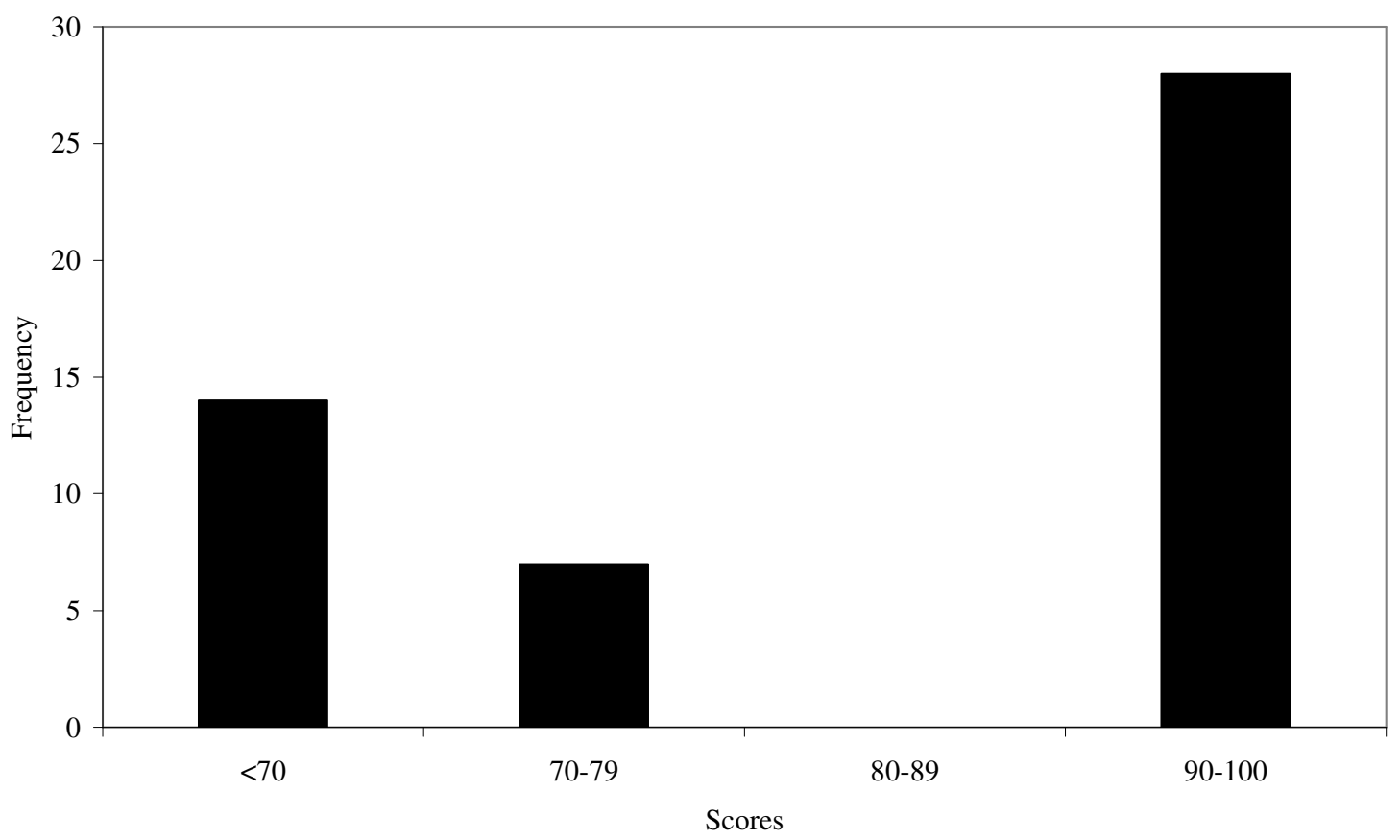


Relative Wetland Size Scores-Western Great Plains Saline Depression Wetland

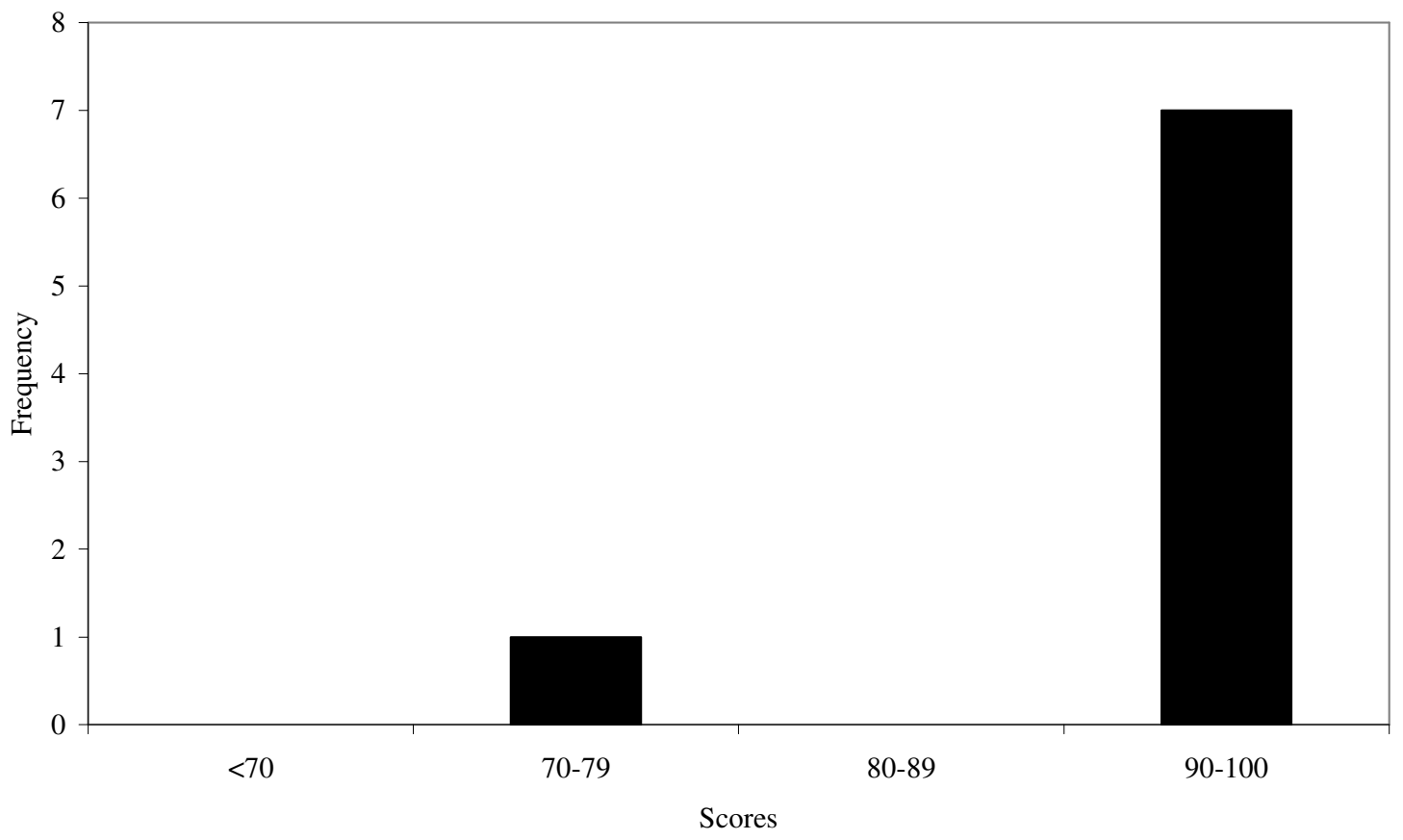

Relative Wetland Size Scores-Northwestern Great Plains Riparian

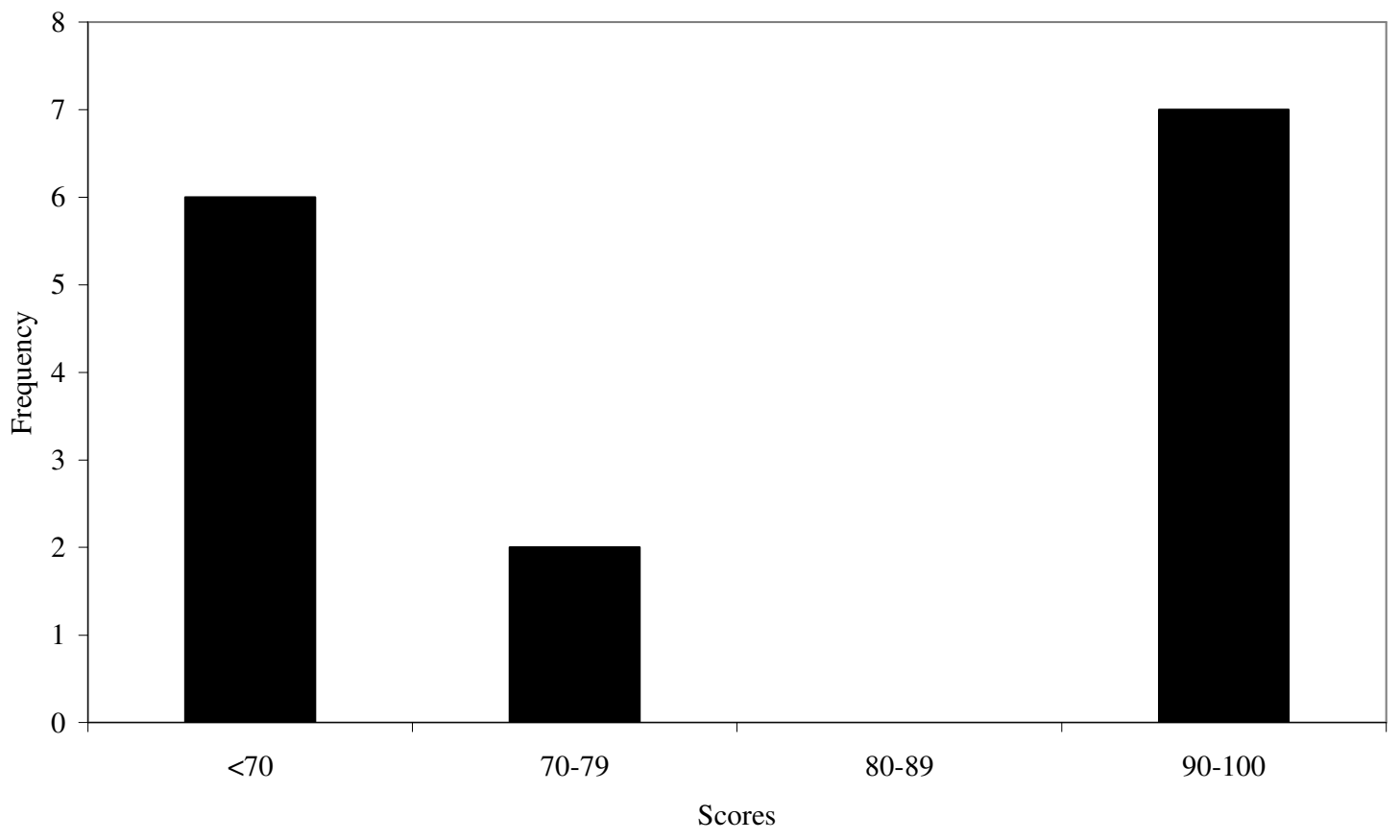


Biotic Composition and Structure Scores-Great Plains Prairie Pothole

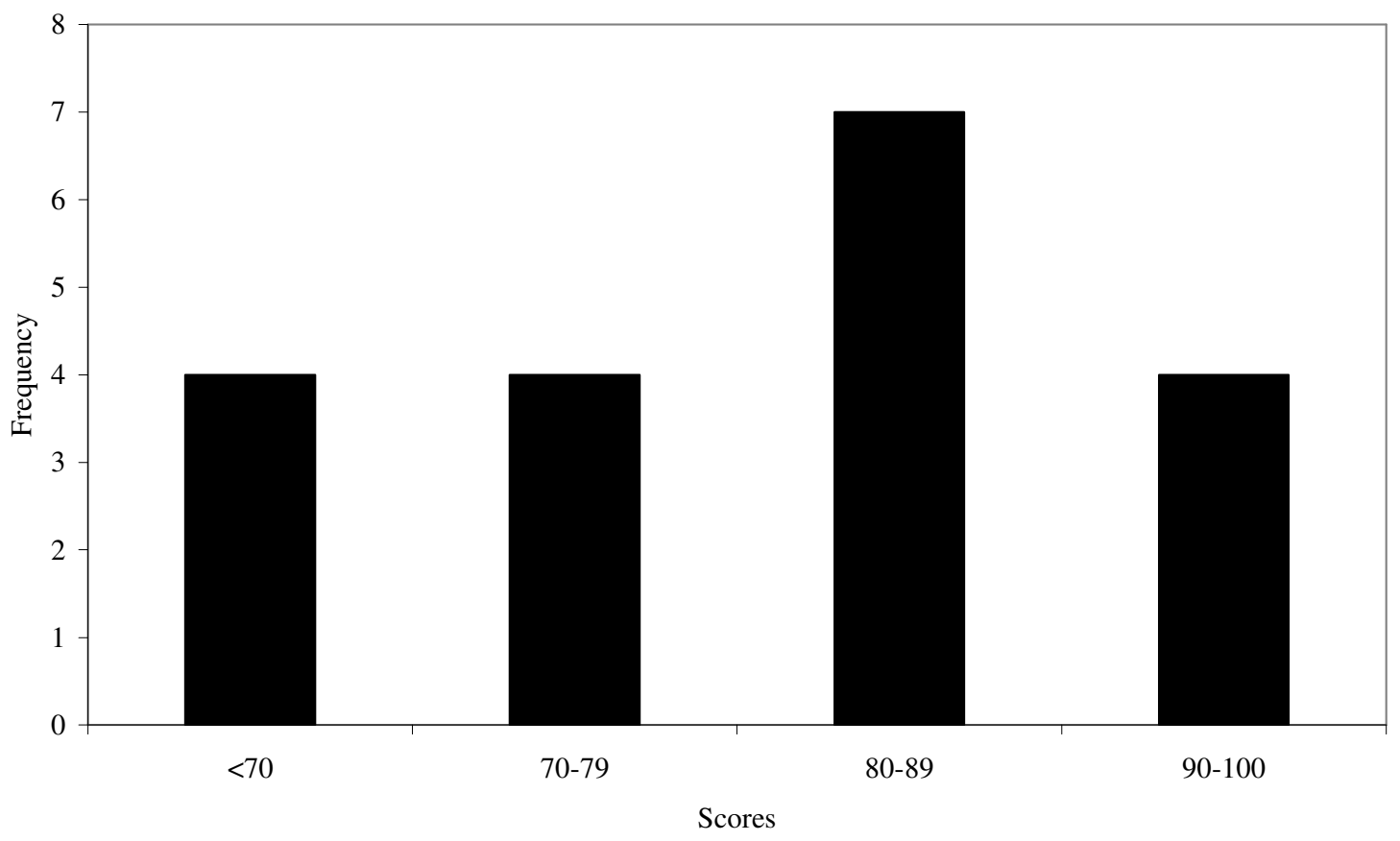

Biotic Composition and Structure Scores-Western Great Plains Closed Depression Wetland

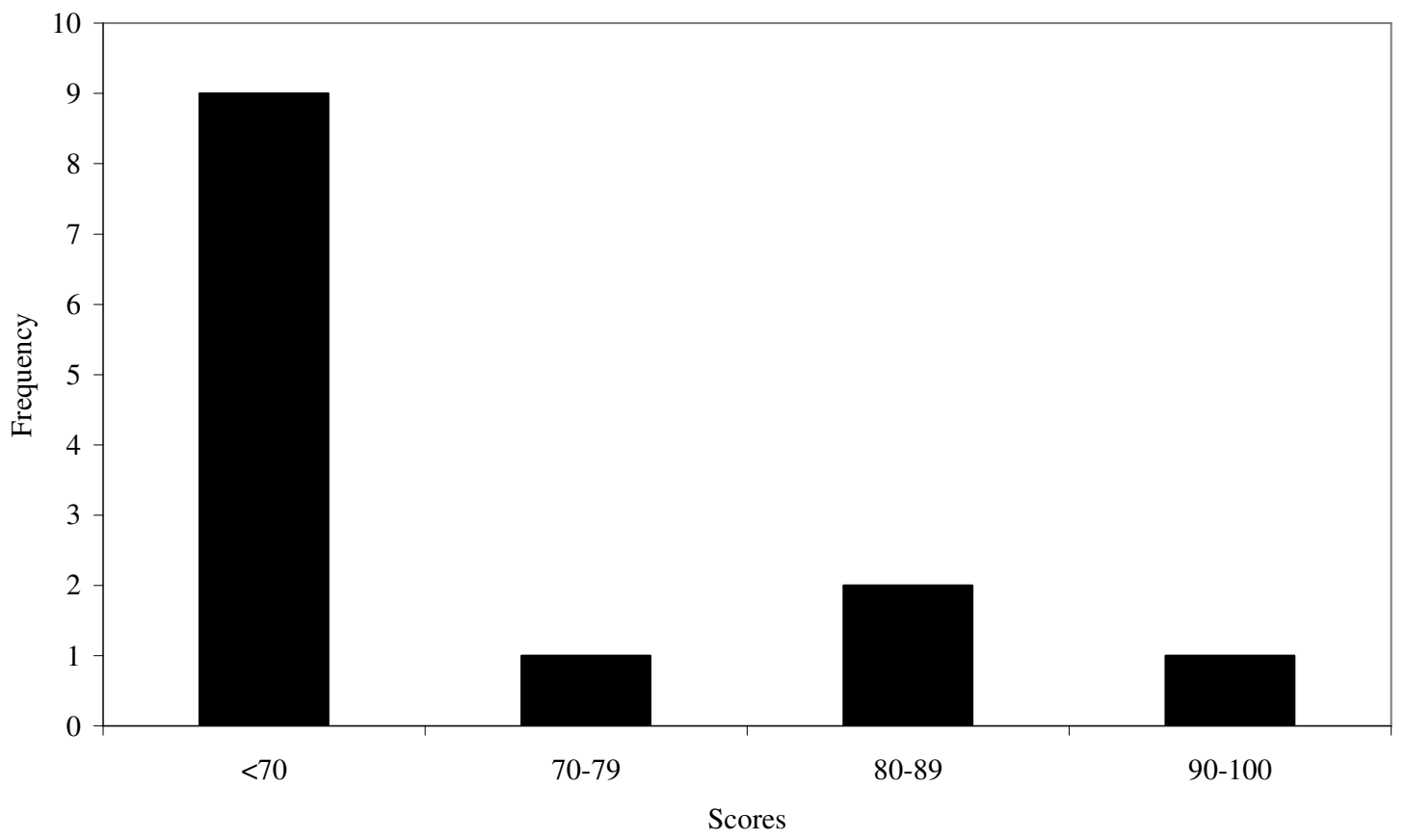


Biotic Composition and Structure Scores-Western Great Plains Open Freshwater Depression Wetland

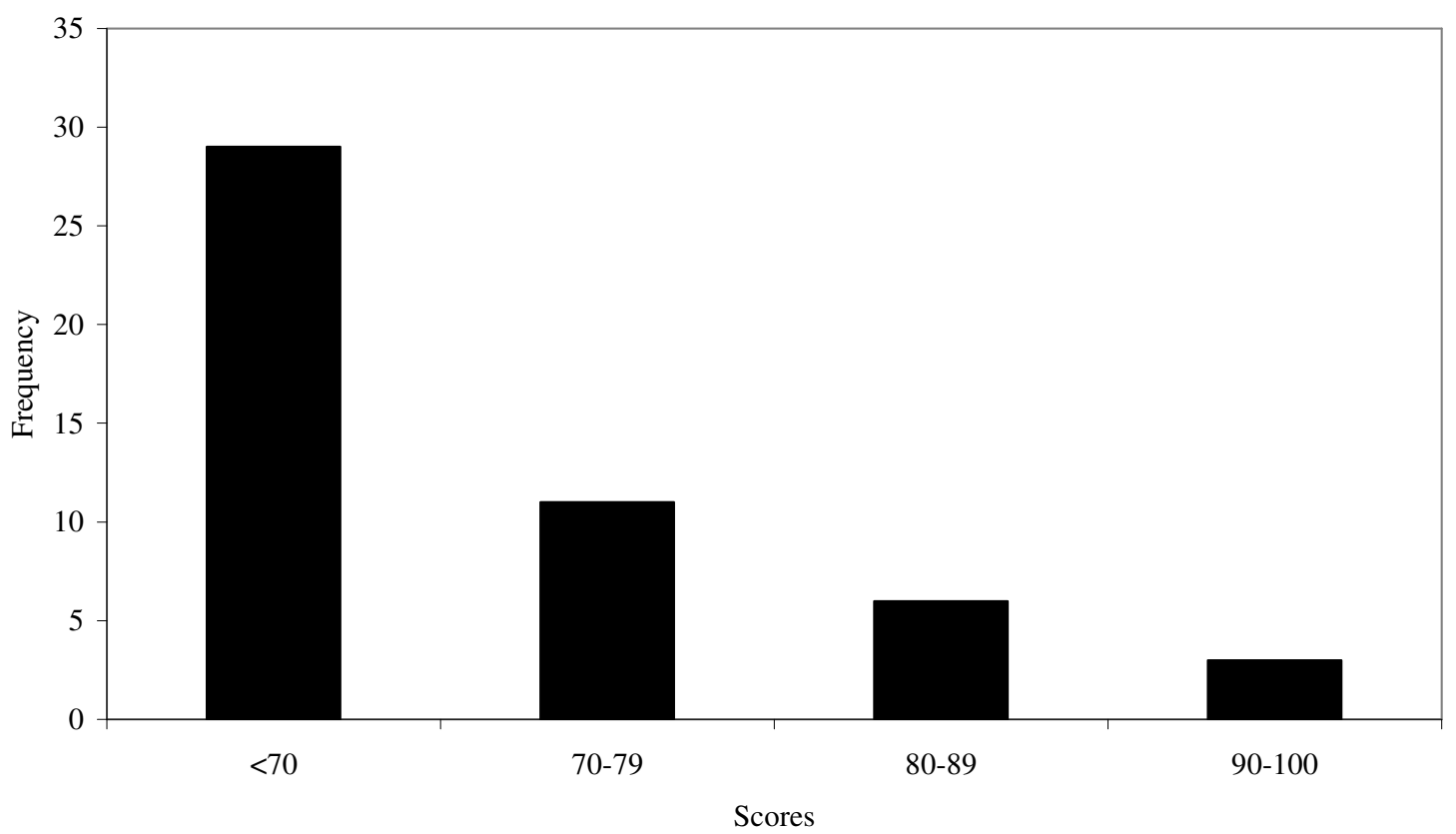

Biotic Composition and Structure Scores-Western Great Plains Saline Depression Wetland

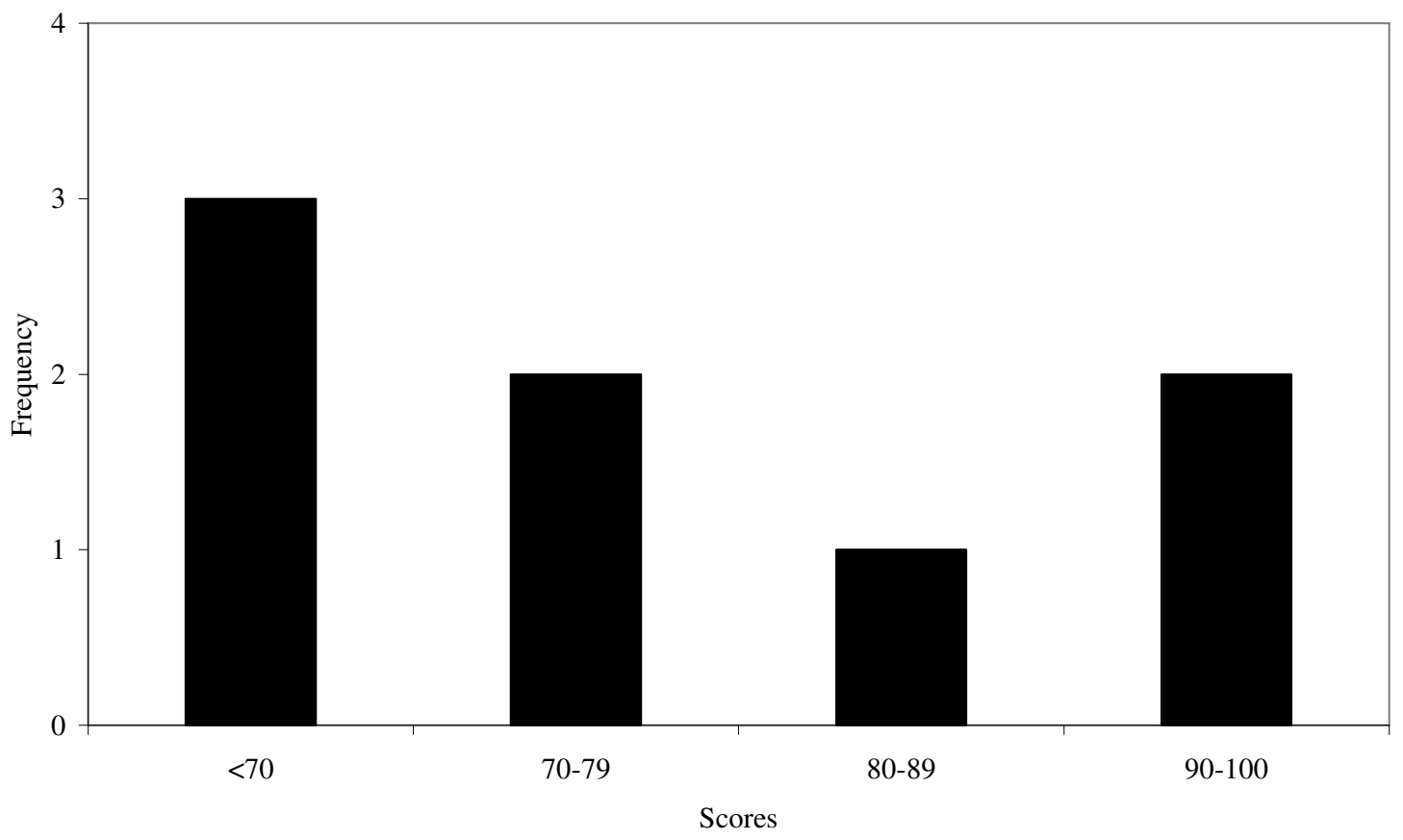


Biotic Composition and Structure Scores-Northwestern Great Plains Riparian

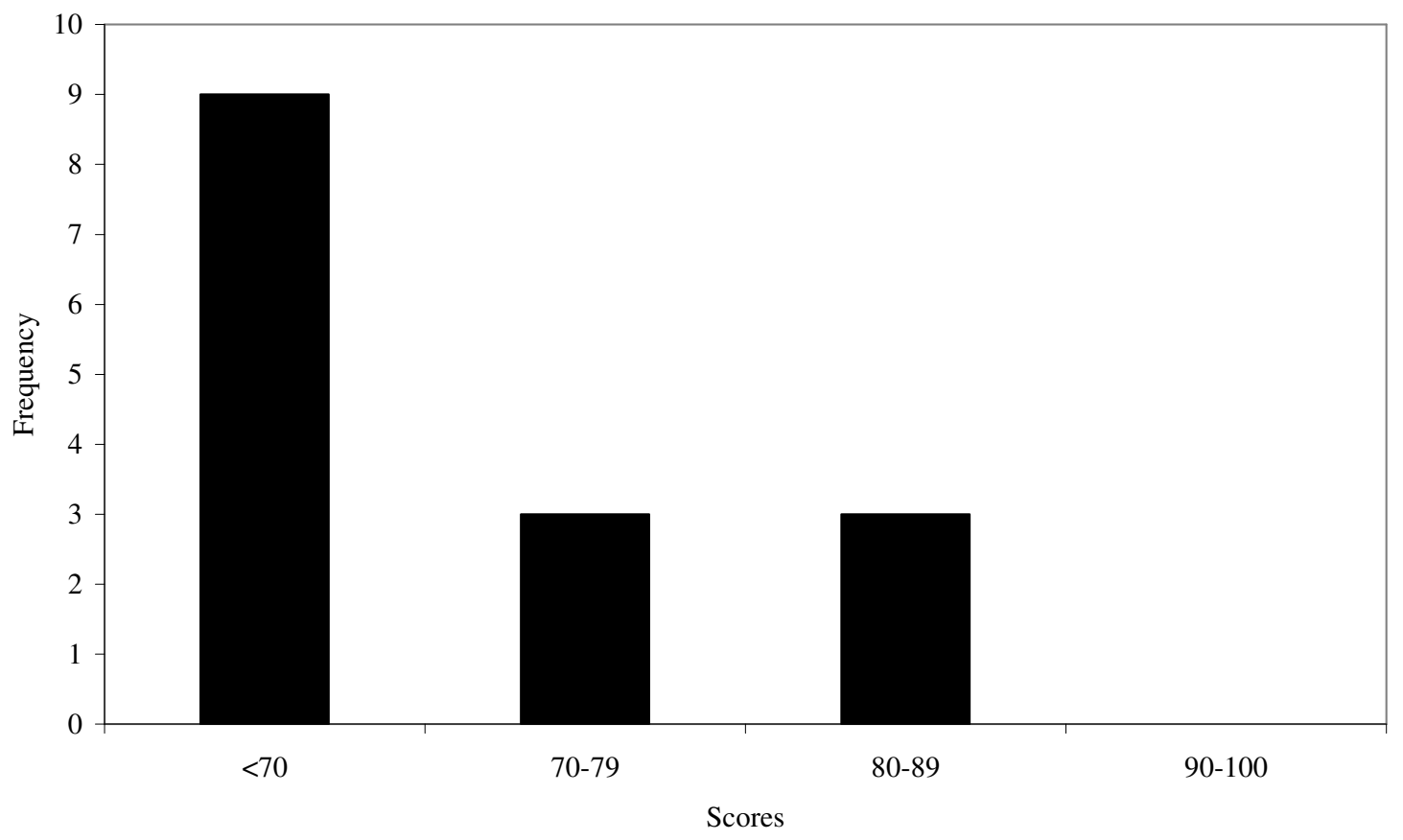

Hydrology Scores-Great Plains Prairie Pothole

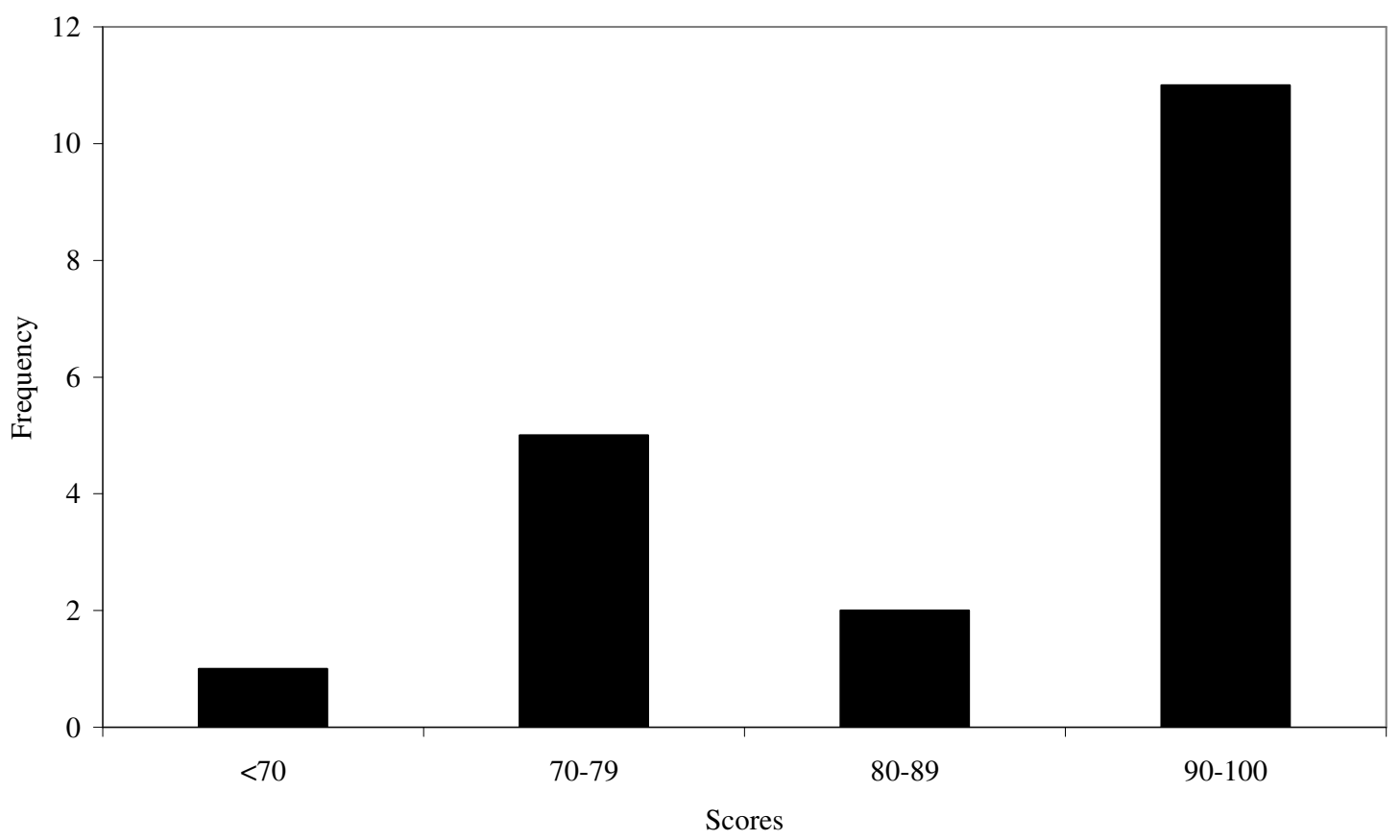


Hydrology Scores-Western Great Plains Closed Depression Wetland

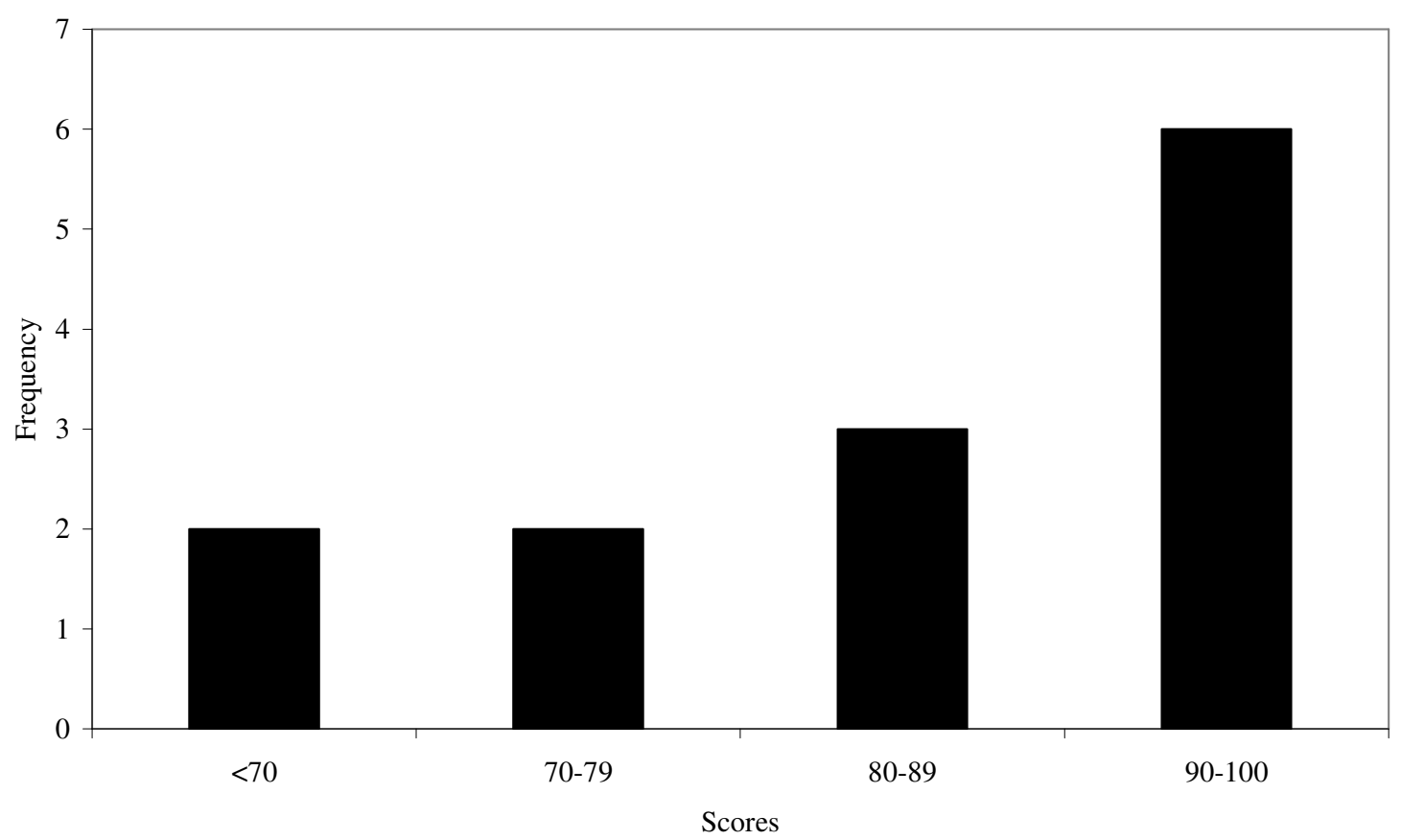

Hydrology Scores-Western Great Plains Open Freshwater Depression Wetland

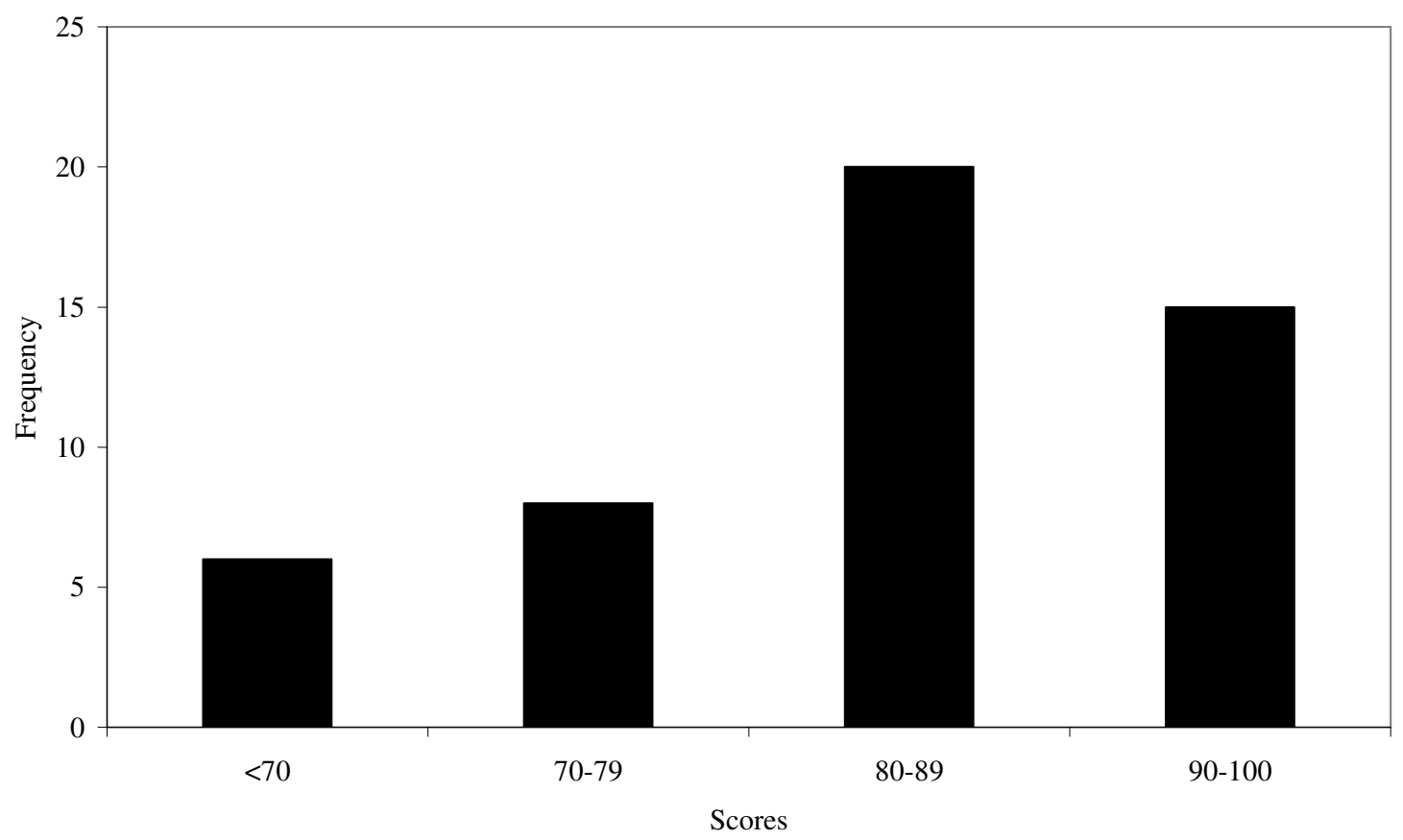


Hydrology Scores-Western Great Plains Saline Depression Wetland

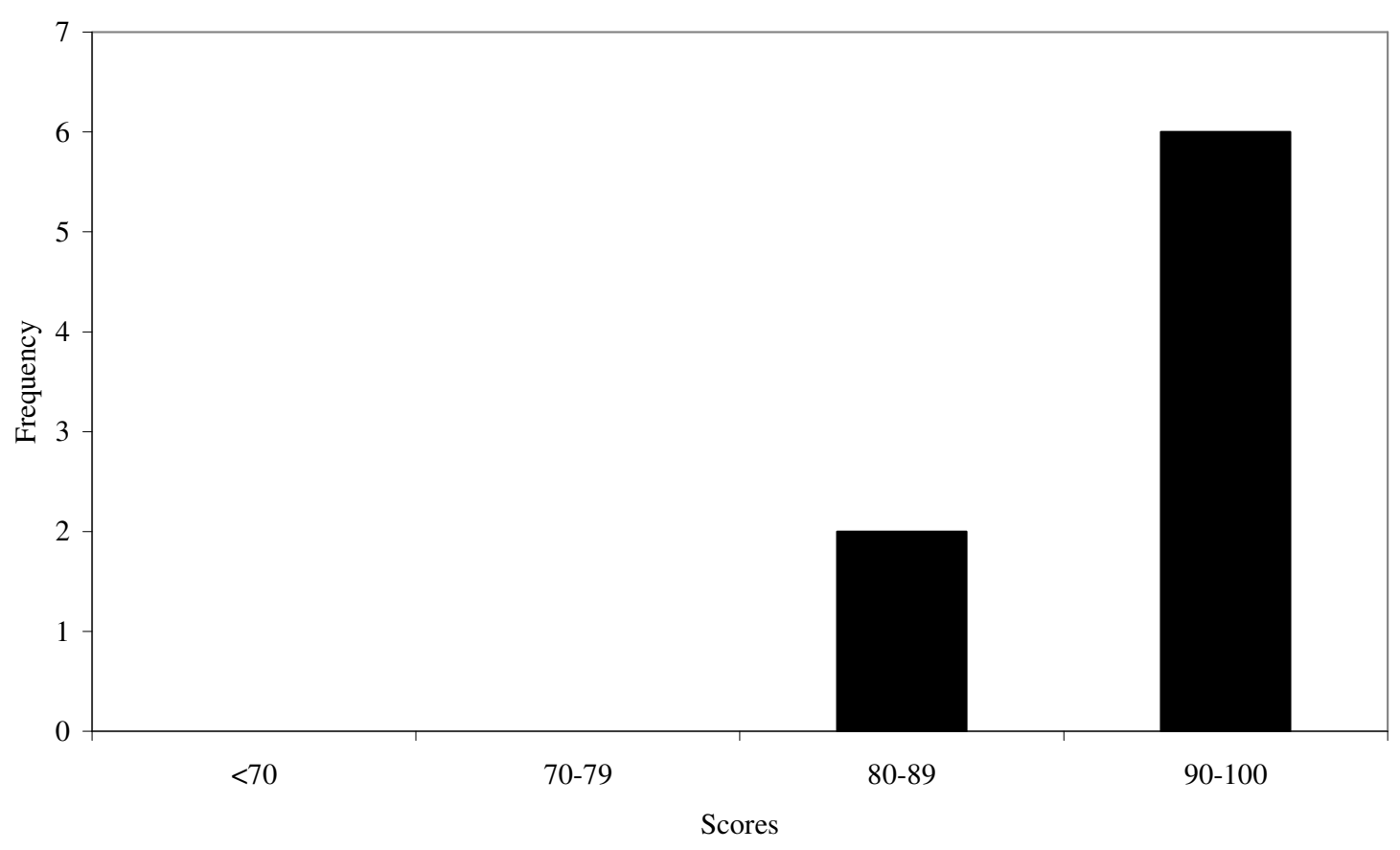

Hydrology Scores-Northwestern Great Plains Riparian

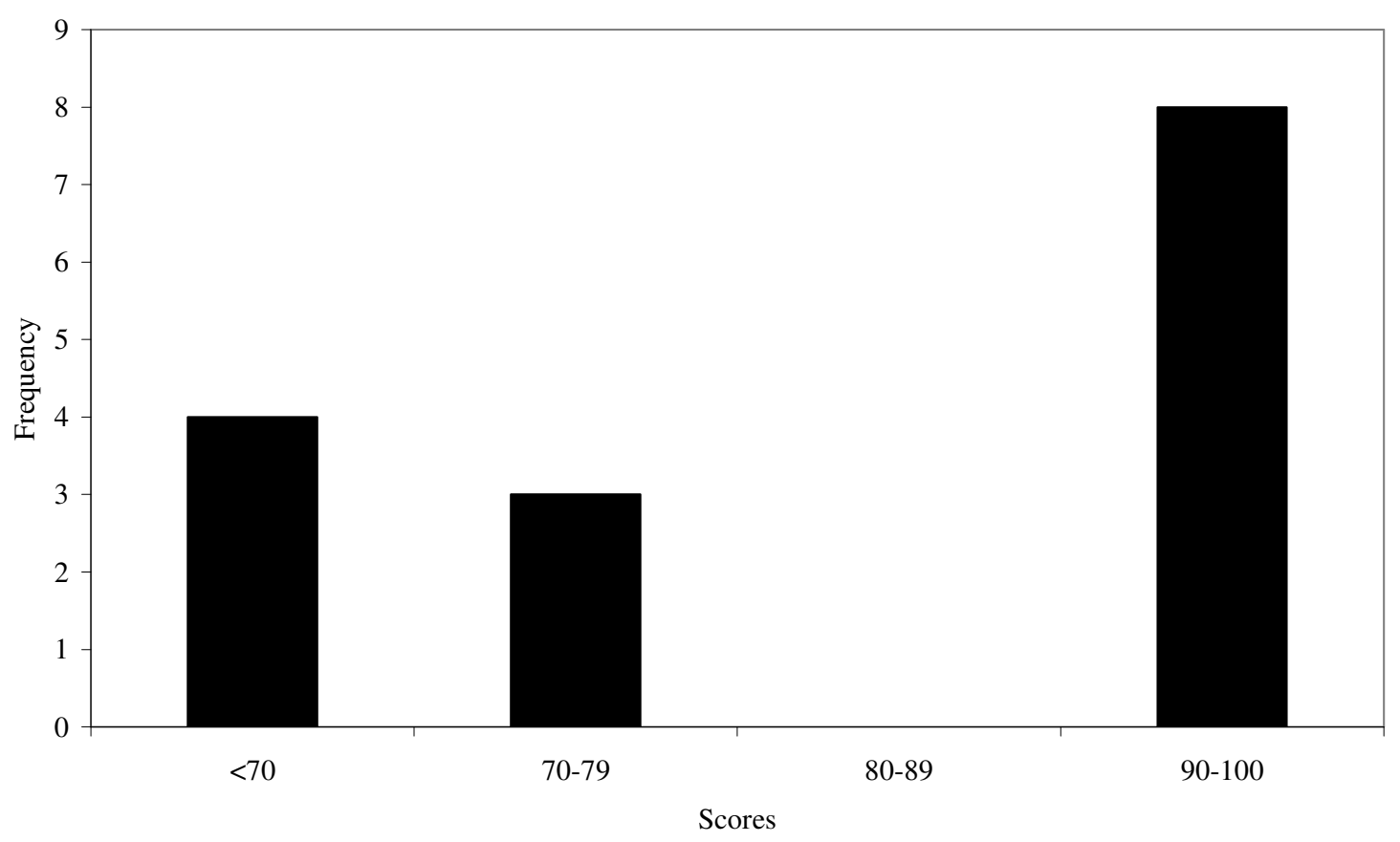


Physicochemical Scores-Great Plains Prairie Pothole

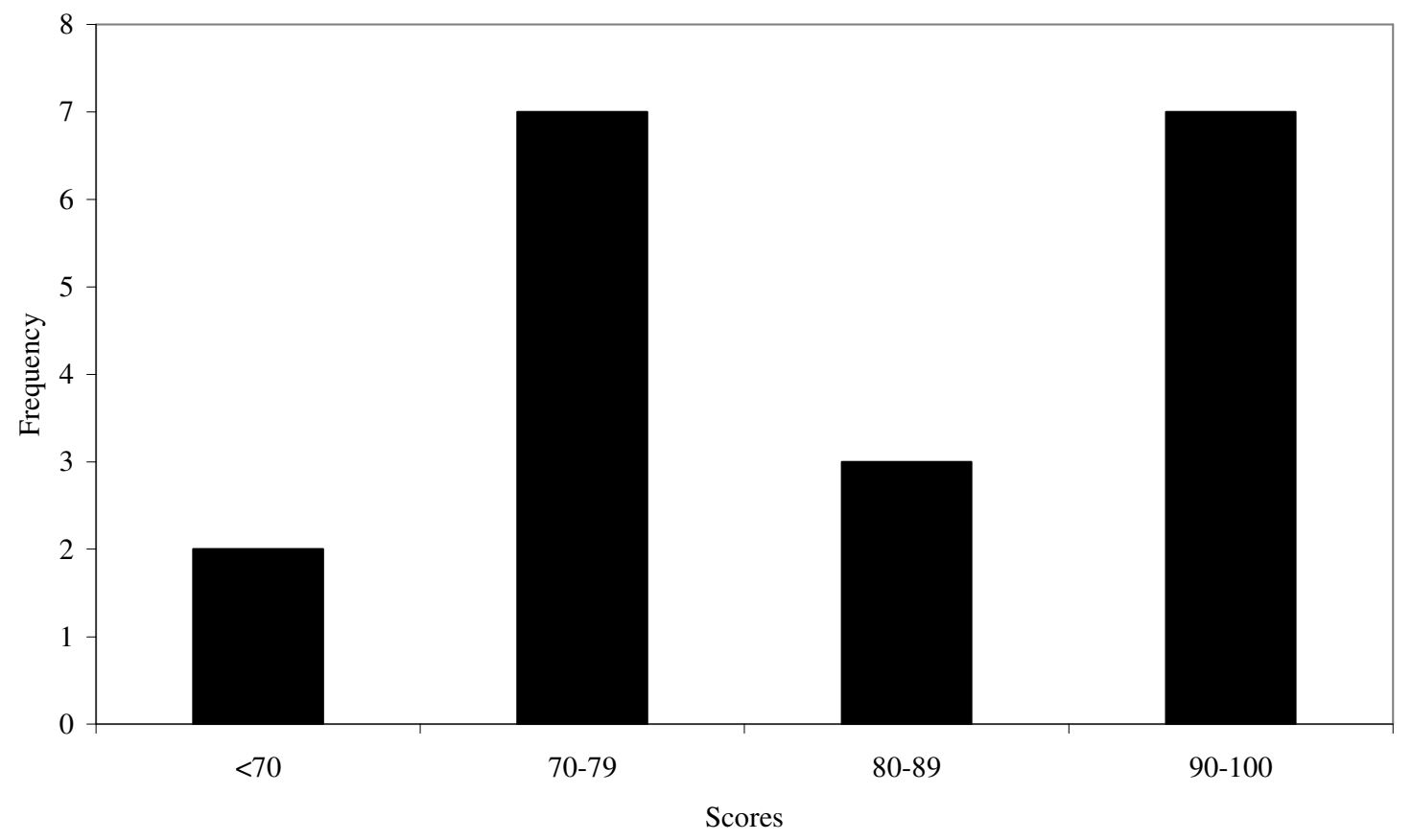

Physicochemical Scores-Western Great Plains Closed Depression Wetland

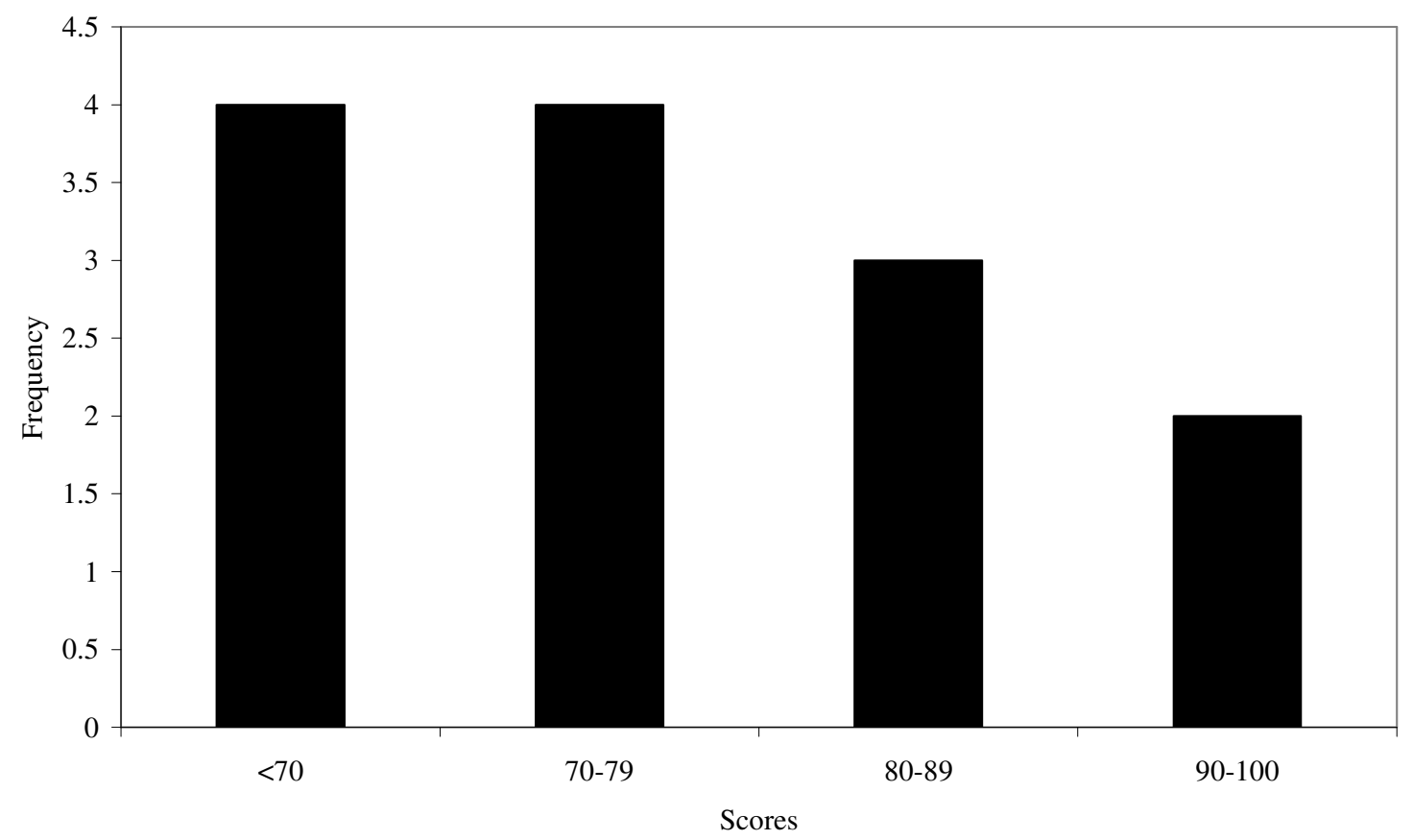


Physicochemical Scores-Western Great Plains Open Freshwater Depression Wetland

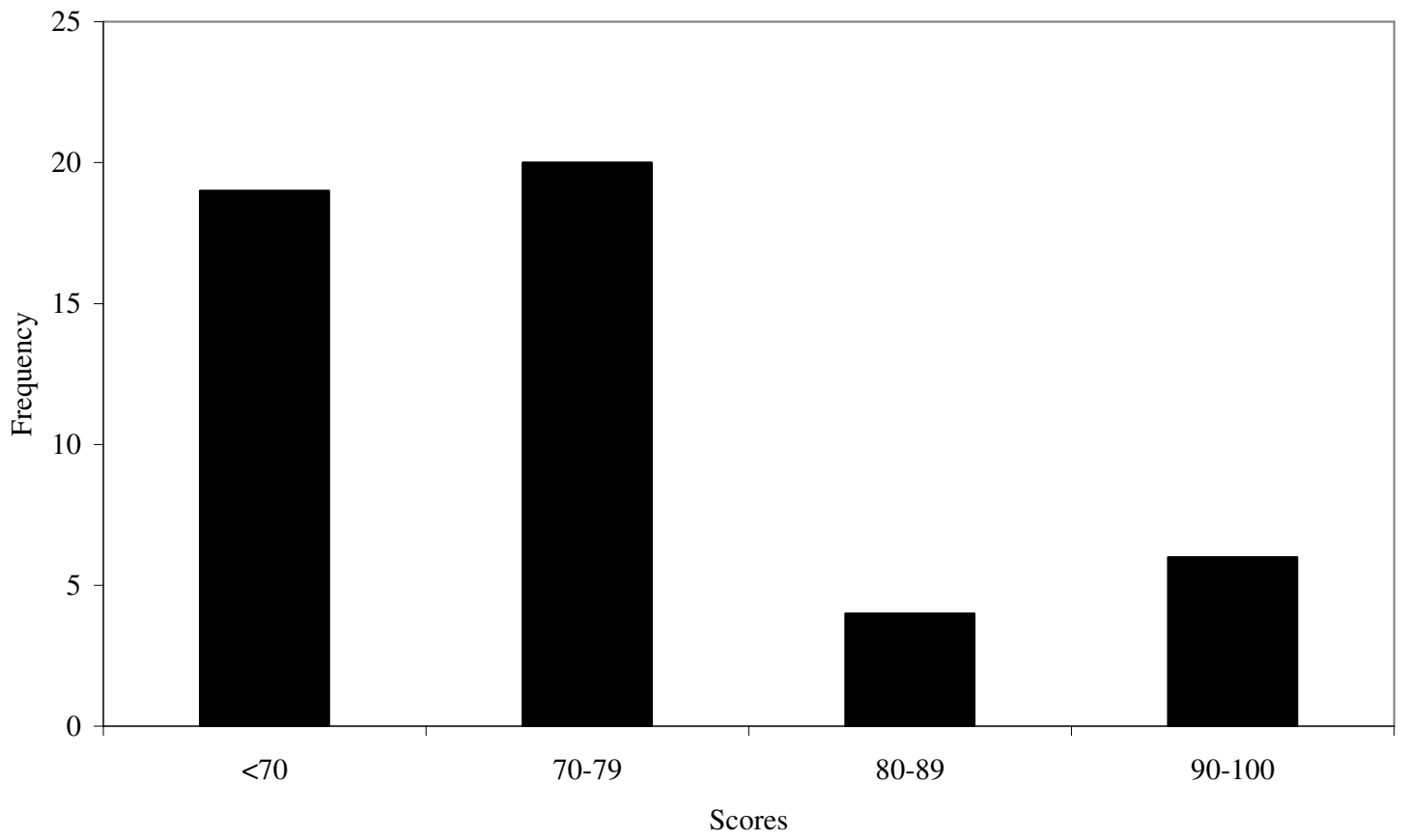

Physicochemical Scores-Western Great Plains Saline Depression Wetland

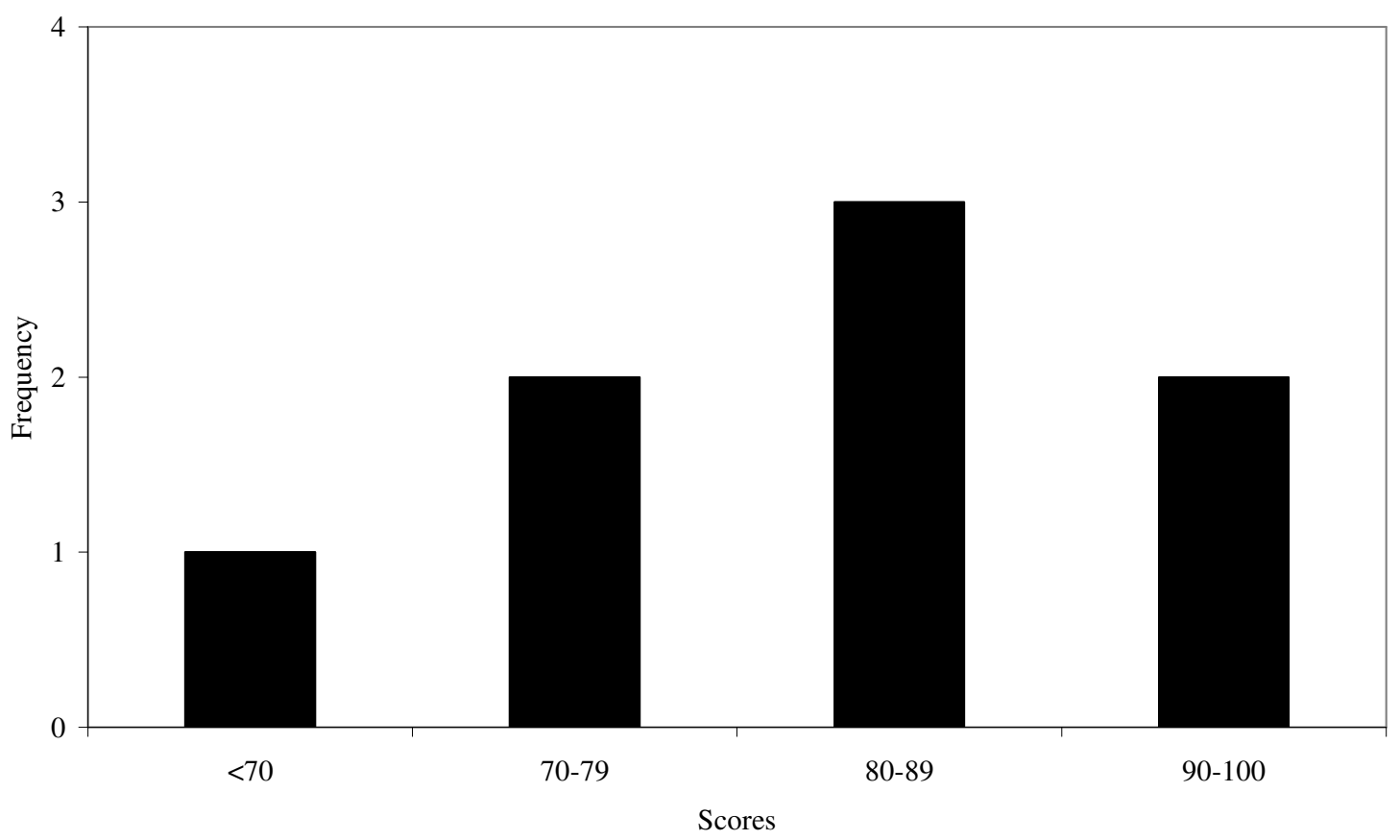


Physicochemical Scores-Northwestern Great Plains Riparian

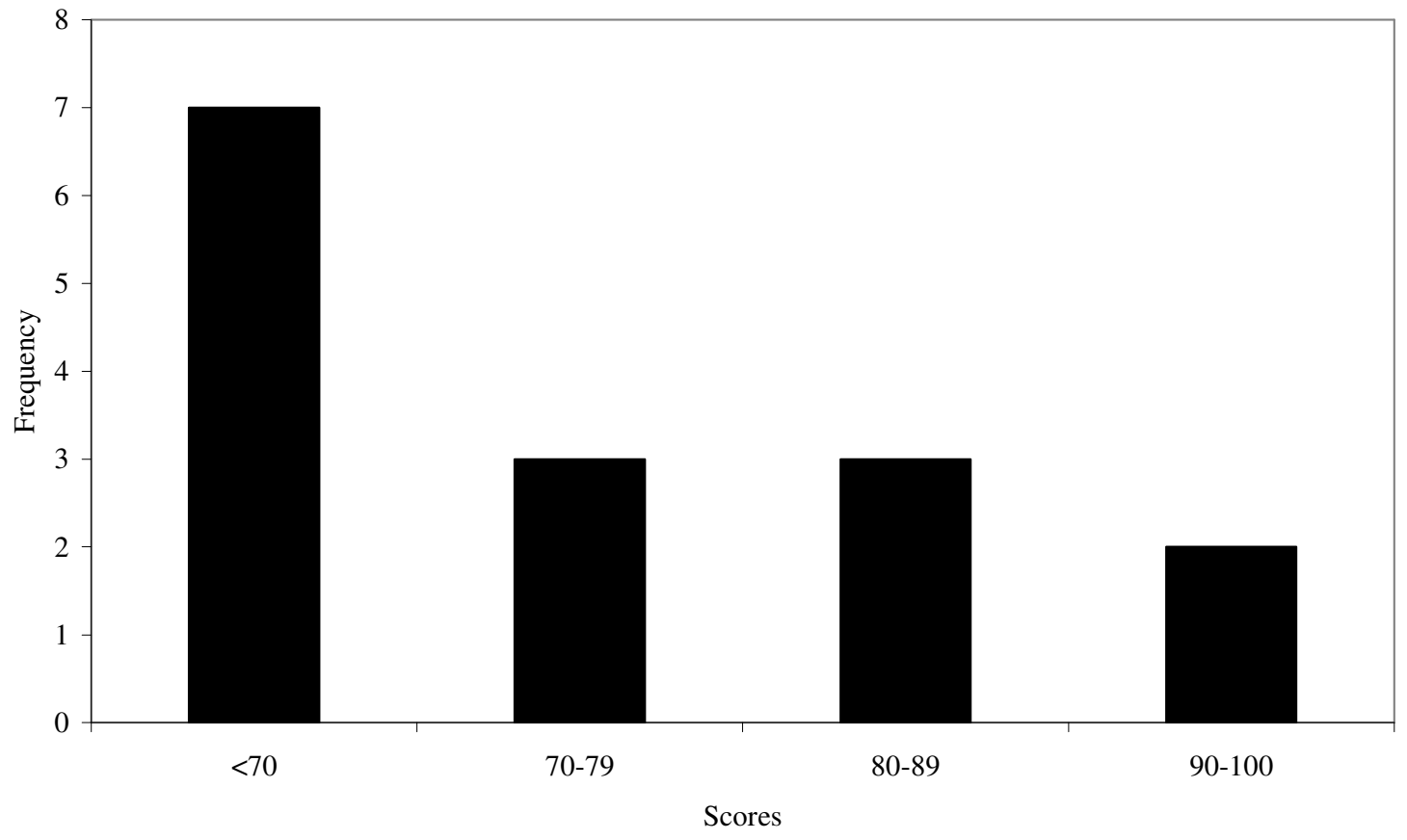

